MAYARA DE LIMA REIS

\title{
O PACTO COMISSÓRIO NO DIREITO ROMANO
}

(Dissertação de Mestrado)

Orientador:

Prof. Titular Eduardo Cesar Silveira Vita Marchi

Faculdade de Direito da Universidade de São Paulo

São Paulo

2014 
Banca Examinadora: 
À minha mãe, por tudo 


\section{Abreviaturas das Fontes}

\begin{tabular}{|c|c|c|}
\hline ABGB & $=$ & Allgemeines Bürgerliches Gesetzbuch \\
\hline Bas. & $=$ & $\begin{array}{l}\text { Basilicorum libri } L X-H \text {. J. SCHELTEMA E N. VAN DER } \\
\text { WAL, Basilicorum libri } L X-\text { series A, Groningen, Wolters, } \\
1953 \text { a } 1983\end{array}$ \\
\hline BGB & $=$ & Bürgerliches Gesetzbuch \\
\hline $\begin{array}{l}\text { C. } \\
11^{\mathrm{a}} \text { ed., }\end{array}$ & $=$ & $\begin{array}{l}\text { Codex Iustinianus - P. KRÜGER, in Corpus iuris civilis II, } \\
\text { Berlin, Weidmann, } 1954\end{array}$ \\
\hline $\mathrm{CC} / 16$ & $=$ & Código Civil Brasileiro de 1916 \\
\hline $\mathrm{CC} / 02$ & $=$ & Código Civil Brasileiro de 2002 \\
\hline $\mathrm{CDC}$ & $=$ & Código de Defesa do Consumidor \\
\hline CIL. & $=$ & Corpus inscriptionum latinarum \\
\hline $\begin{array}{l}\text { Coll. } \\
\text { in }\end{array}$ & $=$ & $\begin{array}{l}\text { Collatio Legum Mosaicarum et Romanarum - J. BAVIERA, } \\
\text { FIRA II }\end{array}$ \\
\hline CPC & $=$ & Código de Processo Civil \\
\hline $\begin{array}{l}\text { C.Th. } \\
\text { Berlin, }\end{array}$ & $=$ & $\begin{array}{l}\text { Codex Theodosianus - T. MOMMSEN e P. M. MEYER, } \\
\text { Weidmann, } 1904\end{array}$ \\
\hline $\begin{array}{l}\text { D. } \\
I, 16^{\mathrm{a}}\end{array}$ & $=$ & $\begin{array}{l}\text { Digesta - T. MOMMSEN E P. KRÜGER, in Corpus iuris civilis } \\
\text { ed., Berlin, Weidmann, } 1904\end{array}$ \\
\hline $\begin{array}{l}\text { Esboço } \\
\mathrm{e}\end{array}$ & $=$ & $\begin{array}{l}\text { Código Civil - Esbôço, Rio de Janeiro, Ministério da Justiça } \\
\text { Negócios Interiores (serviço de documentação), } 1952\end{array}$ \\
\hline $\begin{array}{l}\text { FIRA } \\
\text { al., } 2^{\mathrm{a}}\end{array}$ & $=$ & $\begin{array}{l}\text { Fontes iuris romani anteiustiniani I a III - S. Riccobono et } \\
\text { ed., Firenze, Barbera, } 1940 \text { a } 1943\end{array}$ \\
\hline F.V. & $=$ & Fragmenta Vaticana - J. BAVIERA, in FIRA II \\
\hline Gai. & $=$ & Gai Instituciones - J. BAVIERA, in FIRA II \\
\hline $\begin{array}{l}\text { Inst. } \\
I, 16^{\mathrm{a}}\end{array}$ & $=$ & $\begin{array}{l}\text { Institutiones Iustiniani - P. KRÜGER, in Corpus iuris civilis } \\
\text { ed., Berlin, Weidmann, } 1954\end{array}$ \\
\hline
\end{tabular}


L. Vis. $=\quad$ Lex Visigothorum sive Liber iudiciorum $-\mathrm{K}$. ZEUMER, in Monumenta germaniae histórica, legum sectio I (legum nationum Germanicarum), I (leges Visigothorum), Hannover, Hahnianus, 1902

L. XII Tab. = Lex XII Tabularum - S. RICCOBONO, in FIRA I

Ord. Afons. = Ordenações Afonsinas - Ordenações do Senhor Rey D. Affonso V - livro IIII, Coimbra, Real Imprensa da Universidade, 1792

Ord. Filip. = Ordenações Filipinas - CÂNDIDO MENDES DE AlmEIDA, $14^{\mathrm{a}}$ ed., Rio de Janeiro, Instituto Philomathico, 1870

Ord. Manel. = Ordenações Manuelinas - Ordenações do Senhor Rey D. Manuel - livro IIII, Coimbra, Real Imprensa da Univerdidade, 1797

P. $\quad$ = Las Siete Partidas - J. SANChEZ-ArCILla Bernal (org.), Madrid, Reus, 2004

P. Flor. = Papyri Florentini

S. $\quad=\quad$ Súmula

SB. $\quad=\quad$ Sammelbuch griechischer Urkunden aus Ägypten 


\section{ÍNDICE GERAL}

I. INTRODUÇ̃̃̃O

\section{DA LEX COMMISSORIA PIGNORIBUS}

1. Peculiaridades na aplicação do instituto às garantias reais ....................... 06

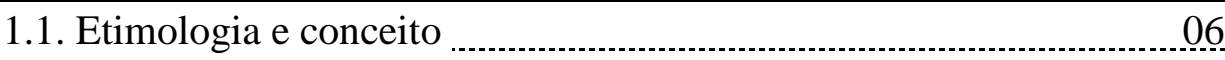

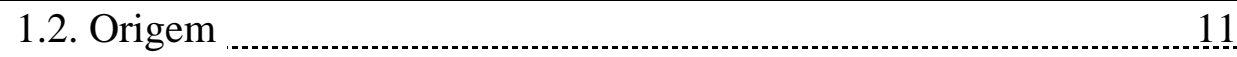

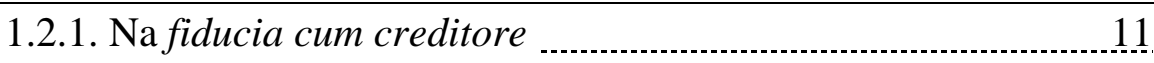

1.2.2. No penhor: A controversa presença da lex commissoria pignoribus nos formulários catonianos 30

1.2.3. Na hipoteca: A discussão sobre a presença da lex commissoria pignoribus em P. Flor. 1 (de 153 d.C.)

1.3. Ius distrahendi como alternativa à severidade dos efeitos comissórios 46

2. Reconstrução histórico-dogmática por analogia com o homônimo pacto acessório à compra e venda 55

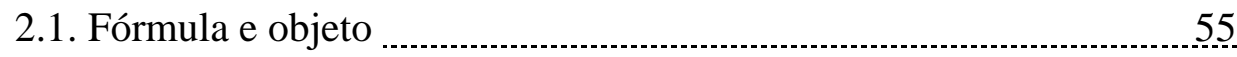

2.2. Enquadramento dogmático (estrutura) 60

2.2.1. Aspectos preliminares: $\mathrm{O}$ problema da condição resolutiva no Direito Romano 60

2.2.2. Estrutura da lex commissoria na venda

2.2.3. Conclusões extensíveis à lex commissoria pignoribus ........ 75

2.3. Exegese de Pomp. 35 ad Sab., D. 18, 3, 2 e de Ulp. 30 ad ed., D. 18, 3,3 79

3. A proibição de Constantino 90

3.1. Exegese de textos polêmicos relativos à proibição 95

3.1. 1. Exegese de C. Th. 3, 2, 1 e C. 8, 34, 3 95

3.1.2. Exegese de Marc. sing. ad form. hypoth., D. 20, 1, 16, 9 ...103 
III. OS ATUAIS LIMITES DA PROIBIÇÃO DO PACTO COMISSÓRIO ÀS GARANTIAS REAIS TÍPICAS

1. A configuração da proibição nas modernas codificações 111

1.1. Codificações que adotam a proibição sem ressalvas 112

1.2. Codificações em que, embora a proibição ainda seja a regra, são expressamente previstas as hipóteses de venda ou dação posteriores ao inadimplemento

1.3. Codificações em que a proibição foi revogada 125

2. A proibição do pacto comissório no $\mathrm{CC} / 02$ 128

2.1. Quanto ao alcance 132

2.2. Quanto ao conteúdo. 134

2.3. Quanto à sanção 139

2.4. Pacto comissório e dação em pagamento posterior ao vencimento145

3. A tutela do devedor necessitado como fundamento histórico da proibição. 149

3.1. Outros fundamentos possíveis 153

3.1. 1. Repressão à usura e à imoralidade 154

3.1. 1. Inderrogabilidade do procedimento judicial 155

3.1. 1. Tutela da garantia geral de todos os credores 157

IV. CONCLUSÃO 161

ÍNDICE DE AUTORES 165

ÍNDICE DE FONTES 172

RESUMO 180

AbSTRaCT 181

BIBLIOGRAFIA 182 


\section{INTRODUÇÃO *}

A inviabilidade de acesso ao crédito tem por grave consequência o engessamento da capacidade do mercado em suprir as carências de consumo, por meio da produção de bens e circulação de riquezas. Nesse sentido, não por acaso, o desenvolvimento de novos mecanismos de obtenção creditícia - e a correspondente preocupação com sua proteção - assume, cada vez mais, significativo papel nas atividades econômicas hodiernas.

A tal cenário, que preza pela existência de um sistema eficaz de garantias que proporcione ao credor a maior segurança possível, contrapõem-se a necessidade de proteção ao devedor e, igualmente, a preocupante crise das chamadas garantias reais tradicionais, consideradas insuficientes às cada vez mais complexas exigências do mercado financeiro ${ }^{1}$.

\footnotetext{
* Nas notas de rodapé utilizadas neste estudo, como regra, se fará referência somente à primeira nota onde os usuais dados bibliográficos de uma determinada obra foram citados pela primeira vez - não se repetindo a mesma nas notas subseqüentes. Assim, por exemplo: "E. C. SILVEIRA MARCHI, Guia de Metodologia cit. (nt. 1 supra), p. 1". Consoante o exemplo, os dados completos do livro encontrar-se-iam na primeira nota de rodapé do trabalho. A mençãoaos autores, no corpo do texto e nas notas de rodapé, será feita mediante o emprego da inicial do prenome e do último sobrenome por extenso e em caixa alta (e.g., P. BONFANTE).

Excepcionalmente, os nomes dos autores luso-brasileiros serão mencionados tal como conhecidos na comunidade acadêmica nacional, facilitando, assim, a tarefa do leitor (assim, e.g., L. Cunha Gonçalves, J. C. Moreira Alves, ORlando Gomes etc). Mesma regra será aplicada aos juristas espanhóis, apesar de ostentarem regra de patronímico própria. Isso para evitar situações em que, e.g., um jurista tão conhecido como A. D'ORS acabe por ser indicado como A. O. PÉREZ-PEIX ou A. D’Ors PÉREZ PeIX. Já com relação aos jurisconsultos romanos e aos autores medievais, os seus nomes sempre serão mencionados em minúscula, excetuada, é claro, a inicial (e.g., Ulpiano, Paulo, Gaio etc).

No que diz respeito à forma de indicação do título das obras, opta-se por reproduzi-lo sem nenhuma inicial maiúscula no meio do título ou subtítulo, salvo os de língua alemã (diante da existência de regra gramatical própria). A razão desta escolha é a inexistência de qualquer consenso acerca da melhor forma, seja na literatura pátria, seja na literatura estrangeira, e a necessidade de uniformizar a técnica de citação.

Quanto à metodologia científica adotada, especialmente no tocante à citação bibliográfica, cf. E. C. Silveira MARChI, Guia de Metodologia Científica (Teses, Monografias e Artigos), $2^{\mathrm{a}}$ ed., Lecce, Grifo, 2004, p. 179-235. Finalmente, quanto às citações às partes internas desta obra, os capítulos serão indicados com numeração expressa em algarismos romanos, e os itens e subitens, em algarismos arábicos. Por exemplo, "cf. II.3" - faz-se menção ao capítulo segundo, terceiro item.

${ }^{1}$ Cf., nesse sentido, P. SimLER, Rapport de synthese, in "Les Garanties de Financement Journées portugaises", t. 47, Librarie Général de Droit et Jurisprudence, Paris, 1996, p. 30. Igualmente, tal insuficiência pode ser encontrada no âmbito das garantias pessoais, que, contudo, dispõem de uma disciplina mais flexível à introdução de novas modalidades da garantia, por não
} 
Como tentativa de superar o mencionado problema, vislumbra-se a adoção de medidas que englobam não apenas a criação e o desenvolvimento de novas garantias reais ${ }^{2}$, mas também tentativas de encontrar soluções que permitam tornar mais elásticas ${ }^{3}$ aquelas já existentes. Nesse diapasão, especialmente no último meio século, tem ganhado relativa força a tendência de que seja questionada a proibição do pacto comissório ${ }^{4}$.

Diferentemente de outros códigos modernos, também considerados de tradição romano-germânica ${ }^{5}$, o CC/02 não trouxe o termo "comissório" ou quaisquer de suas possíveis flexões gramaticais ao tratar da matéria ${ }^{6}$. A doutrina brasileira $^{7}$, no entanto, certamente por força de seu correspondente latino, aplica-a

se sujeitarem ao princípio do numerus clausus dos direitos reais - cf. F. MASTROPAOLO, I Contratti Autonomi di Garanzia, 2ª ed., G. Giappichelli, Torino, 1995.

${ }^{2}$ Foi o que ocorreu no Brasil com a introdução da alienação fiduciária em garantia através da chamada Lei de Mercados Capitais (Lei $n^{\circ}$ 4728/1965). Sobre o tema, de que se tratará incidentalmente ao longo deste trabalho, - cf., especialmente, J. C. MOREIRA ALVES, Da alienação fiduciária em garantia, $3^{\mathrm{a}}$ ed., Forense, Rio de Janeiro, 1987, pp. 11 e ss; ORLANDO GOMES, Alienação fiduciária em garantia, RT, Rio de Janeiro, 1975, pp. 8 e ss.

${ }^{3}$ A interessante expressão é empregada por M. BUSSANI - cf. Rapport italien, in "Les garanties de financement - Journées portugaises", t. 47, Librarie Général de Droit et Jurisprudence, Paris, 1996, p. 217.

${ }^{4}$ Dentre os principais trabalhos que tratam do tema no direito civil atual, estão aqueles da doutrina italiana, precursora em seu estudo - cf., especialmente, C. MASSIMO BIANCA, Il divieto del patto commissorio, Milano, Giuffrè, 1957; V. LOJACONO, Il patto commissorio nei contratti di garanzia, Milano, Giuffrè, 1952; A. SASSI, Garanzia del credito e tipologie commissorie, Napoli, Edizioni Scientifiche Italiane, 1999; F. ANELl, Problemi dell'alienazione in funzione di garanzia - Trasferimento dei diritti e divieto del patto commissorio, Pavia, Zanichelli, 1992; i.d., L'alienazione in funzione di garanzia, Milano, Giuffrè, 1996; F. GiGLIOTTI, Il divieto del patto commissorio, Napoli, Edizioni Scientifiche Italiane, 1997; N. CIPRIANI, Patto commissorio e patto marciano - Proporzionalità e legitimità delle garanzie, Napoli, Edizioni Scientifiche Italiane, 2000.

${ }^{5}$ Cf., e.g., o Codice Civile italiano ("patto commissorio", artigo 2.744), o Código Civil português ("pacto comissório", artigo 694), o Código Civil argentino ("pacto comisorio", artigo 1.203) e o Código Civil espanhol ("pacto comisorio", artigo 1.859).

${ }^{6}$ No mesmo sentido, e.g, o Code Napoléon francês, que, contudo, também sem mencionar expressamente o vocábulo, autoriza a cláusula comissória em seu artigo 2.348; o Código Civil uruguaio, que menciona o pacto comissório à compra e venda, mas não aplica o termo em seu artigo 2.338, que prevê a proibição; igualmente a este, o Código Civil chileno (artigo 2.397).

O Bürgerliches Gesetzbuch alemão $(B G B)$, em seu §1.149 utiliza a expressão mais genérica "Befriedigungsabreden". Como se verá adiante (cap. III), embora apresente algumas similitudes, trata-se de instituto bastante diverso daquele que ora se estuda.

7 Cf., apenas a título exemplificativo em manuais corriqueiramente utilizados por estudantes, S. S. Venosa, Direito civil - Direitos reais, v. 5, $11^{\text {a }}$ ed., São Paulo, Atlas, 2011, p. 496 e ss.; CAIO MárIO, Instituições de direito civil, v. 4, 19a ed., Rio de Janeiro, Forense, 2012, pp. 319 e ss.; MARIA Helena Diniz, Curso de direito civil brasileiro - Direito das coisas, v. 4, $27^{\mathrm{a}}$ ed., São Paulo, Saraiva, 2012, pp. 500 e ss. 
exaustivamente ao referir-se à proibição prevista nos artigos 1.428 e 1.365 , ambos do mencionado diploma legal ${ }^{8}$.

De modo praticamente unânime, ainda que não expressamente, os privatistas brasileiros procuram justificar a supracitada proibição sob 0 fundamento de que a suposta ratio de uma decisão do Imperador Constantino do ano 320 d.C. ${ }^{9}$ se estenderia aos dias atuais ${ }^{10}$. Em outras palavras, para esses autores, a regra justificar-se-ia, sic et simpliciter, pela necessidade de que se protegesse o devedor de uma prática ainda considerada insuportável, abusiva.

No entanto, com a devida vênia, semelhante conclusão nada mais parece ser do que fruto de mera reprodução encadeada de ideias já ultrapassadas, diretamente resultantes da ausência de uma maior reflexão pátria sobre a questão. A própria regra romana de proibi-lo, isoladamente considerada, ainda carece de estudo que lhe seja definitivamente conclusivo ${ }^{11}$.

Como explicar que um instituto por séculos aplicado nas relações negociais romanas tenha podido ser objeto de tão grande repúdio? Esta é a principal pergunta que nas próximas páginas se pretende responder. Mais do que

${ }^{8}$ Já o CC/1916 trazia a expressão em seu artigo 1.163, que, no entanto, trata da venda.

${ }^{9}$ Cf. C. Th 3,2,1 (de 320 d.C.) e Const., C. 8, 34, 3 (de 326 d.C.).

${ }^{10}$ Cf., entre outros, F. C. PONTES DE MiRANDA, Tratado de direito privado, t. 20, $3^{\mathrm{a}}$ ed., são Paulo, RT, 1983, p. 30; L. R. PEREIRA, Direito das coisas, v. 2, Brasília, Senado Federal, 2004, p. 21; C. Bevilacqua, Código Civil dos Estados Unidos do Brasil, v. 3, Rio de Janeiro, s/ed., s/d., p. 1229; T. FulgenCIO, Direito real de hipoteca, .v. 1, $2^{\mathrm{a}}$ ed., Rio de Janeiro, Forense, 1960, pp. 110111; J. X. CARVAlHO DE MENDOnÇA, Tratado de direito comercial brasileiro, $5^{\mathrm{a}}$ ed., v. 6, Rio de Janeiro, Freita Bastos, 1956, p. 631; CAIO MÁRIO, Instituições de direito civil, v. 4, 15 a ed., Rio de Janeiro, Forense, 2001, pp. 209-210; S. RoDRIGUES, Direito civil - Direito das coisas, v. 5, $20^{\mathrm{a}}$ ed., São Paulo, Saraiva, 1993, pp. 337-338; E. EsPÍNOLA, Os direitos reais limitados ou direitos reais sobre coisa alheia e os direitos reais de garantia no direito brasileiro, Rio de Janeiro, Conquista, 1958, p. 322; S. VenOSA, Direito civil - Direitos reais, v. 5, $3^{\text {a }}$ ed., São Paulo, Atlas, 2003, p. 473; L. C. PENTEAdO, Direito das coisas, São Paulo, RT, 2008, p. 437.

${ }^{11}$ Dentre os não muito trabalhos que tratam diretamente do instituto no direito romano - cf. A. BuRdESE, "Lex commissoria” e "ius distrahendi" nella "fiducia” e nel "pignus", Torino, Giappichelli, s.d.; A. BISCARDI, La "lex commissoria” nel sistema delle garanzie reali, in Studi in Onore di Emilio Betti, v. 2, Milano, Giuffrè, 1962; A. BISCARDI, Le garanzie reali del credito, Siena, Giubbi \& C., 1957; E. ALBERTARIO, Sulla nullità del patto commissorio aggiunto al mutuo ipotecario, in Rivista del diritto comerciale e del diritto generale delle obligazioni, XXII, n. 5, Milano, Francesco Vallardi, 1924; C. LONGO, Sulla "in diem addictio" e sulla "lex commissoria" nella vendita, in BIDR (31), 1921; C. PIERINI, La legge commissoria, Pisa, T. Nistri \& Co., 1886; G. ACUTIS, De lege commissoria (Digesto, Libro XVIII, Titolo III), Torino, Subalpina, 1901; A. SACCHI, Sul patto commissorio in diritto romano, in Archivio Giuridico, v. 55, Pisa, Archivio Giuridico, 1895; F. WIEACKER, Lex commissoria - Erfüllungszwang und Widerruf im römischen Kaufrecht, Berlin, Springer, 1932. 
uma simples divagação histórica, acredita-se que a tentativa de reconstrução da lex commissoria seja um importante instrumento de auxílio à melhor compreensão do tratamento dado ao pacto comissório pelo $\mathrm{CC} / 02$ e por outros tantos ordenamentos modernos ${ }^{12}$.

Diante da apresentação das controvérsias que ainda remanescem sobre lex commissoria romana, propõe-se:

a) a discussão acerca das origens do instituto em relação aos direitos reais de garantia, com a análise de fontes, inclusive não-jurídicas, e suas consequentes insterpretações doutrinárias;

b) a análise do problema da potestividade de exercício da lex commissoria na venda e sua análoga aplicação às garantias, a partir da exegese de Pomp. 35 ad Sab., D. 18, 3, 2 e Ulp. 30 ad ed. D. 18, 3, 3;

c) a reconstrução da fórmula do instituto, como instrumento para melhor delimitar sua estrutura e objeto;

d) sempre com base nas fontes, elencar os possíveis motivos que teriam levado à proibição do Imperador Constantino, reproduzida em C. Th. 3, 2, 1 e C. 8, 34, 3 (de 320 d.C.).

e) estabelecer, em que medida, pôde a lex commisoria romana influcenciar a proibição da cláusula comissória nos atuais ordenamentos jurídicos, em especial, o brasileiro.

A fim de melhor atender aos propósitos que aqui se estabelece, decidiu-se pela divisão do presente trabalho em duas grandes partes.

Na primeira, tratar-se-á mais amplamente da lex commissoria romana, seja em relação às peculiaridades apresentadas no âmbito das garantias reais ${ }^{13}$, seja em relação à tentativa de reconstrução de uma lex commissoria pignoribus por analogia ao homônimo pacto acessório à venda ${ }^{14}$.

$\mathrm{Na}$ segunda, serão estudados os reflexos modernos da regra, especialmente no âmbito do CC/02, com a análise panorâmica dos atuais limites

\footnotetext{
${ }^{12}$ Cf. item III. 1

${ }^{13}$ Cf. item II.1.

${ }^{14}$ Cf. item II.2.
} 
da proibição, sua aplicação nos ordenamentos modernos e os principais fundamentos que tal medida justificam ${ }^{15}$.

Por fim, é mister que se faça uma breve delimitação negativa dos contornos que se objetiva traçar no desenvolvimento desta dissertação: não se procederá à análise detalhada de questões práticas acerca da hodierna estrutura e função do pacto comissório, tampouco da aplicação das formas típicas de garantia nas relações de direito privado, senão de maneira incidental e com o intuito de relacioná-las à proibição romana e suas consequências, na medida em que se prestem à melhor compreensão da dimensão do instituto.

\footnotetext{
${ }^{15}$ Cf. item III.
} 
II. DA LEX COMMISSORIA PIGNORIBUS

\section{Peculiaridades na aplicação do instituto Às GARANTIAS REAIS}

\subsection{ETIMOLOGIA E CONCEITO}

Diferentemente de outros códigos modernos também considerados de tradição romano-germânica ${ }^{16}$, o CC/02 não trouxe o termo "comissória" ou quaisquer de suas possíveis flexões gramaticais ao tratar da matéria ${ }^{17}$.

A doutrina brasileira $^{18}$, no entanto, certamente por força de seu correspondente latino, aplica-a exaustivamente ao referir-se à proibição prevista nos artigos 1.428 e 1.365 , ambos do mencionado diploma legal ${ }^{19}$. Para uma mais adequada explicação de tal escolha, no entanto, fazem-se imprescindíveis algumas considerações de caráter geral.

${ }^{16}$ Cf., e.g., o Codice Civile italiano ("patto commissorio", artigo 2.744), o Código Civil português ("pacto comissório", artigo 694), o Código Civil argentino ("pacto comisorio", artigo 1.203) e o Código Civil espanhol ( "pacto comisorio", artigo 1.859).

${ }^{17}$ No mesmo sentido - cf., e.g, o Code Napoléon, que, contudo, também sem mencionar expressamente o vocábulo, autoriza a cláusula comissória em seu artigo 2.348; o Código Civil uruguaio, que menciona o pacto comissório em matéria de venda, mas não aplica o termo em seu artigo 2.338, que prevê a proibição; igualmente a este último, o Código Civil chileno (artigo 2.397).

O Bürgerliches Gesetzbuch alemão $(B G B)$, em seu $§ 1.149$, utiliza a expressão mais genérica “Befriedigungsabreden” relativamente à hipoteca, e, na §1.229, “Verfallvereinbarung”, em correspondência ao penhor. As peculiaridades dos sistemas alemão e de outros países estrangeiros serão analisadas adiante (cap. III).

18 Apenas a título exemplificativo, dentre os autores já citados (nt. supra) - cf. S. S. Venosa, Direito civil - Direitos reais, v. 5, 11 a ed., São Paulo, Atlas, 2011, p. 496 e ss.; CAIO MÁRIO, Instituições de direito civil, v. 4, 19a ed., Rio de Janeiro, Forense, 2012, pp. 319 e ss.; Maria Helena Diniz, Curso de direito civil brasileiro - Direito das coisas, v. 4, $27^{\mathrm{a}}$ ed., São Paulo, Saraiva, 2012, pp. 500 e ss.

${ }^{19} \mathrm{O}$ CC/16 traz a expressão em seu artigo 1.163, que, no entanto, refere-se ao regime da venda, não reproduzido no $\mathrm{CC} / 02$. 


\section{O termo "commissoria" deriva secundariamente de "committere"} (committere, commissum, commissorius $)^{20}$, verbo latino de terceira declinação cuja pluralidade de correspondentes semânticos permite inúmeras interpretações quanto a seu real alcance e sentido no instituto ora estudado.

De modo genérico, dentre os diversos significados ${ }^{21}$ que lhe poderiam ser atribuídos destacam-se:

(i) “incorrer" (em uma pena) ${ }^{22}$;

(ii) "entregar",23;

${ }^{20} \mathrm{Cf}$., entre outros, A. ERnOUT- A. MeILlET, Dictionnaire étymologique de la langue latine - Histoire des mots, $4^{\mathrm{a}}$ ed., Paris, Klincksieck, 2001, p. 724.

${ }^{21}$ As informações relativas ao uso do verbo nas fontes jurídicas e autores latinos - aos quais se reporta para verificar os paralelos com os usos jurídicos do vocábulo - foram obtidas nos índices de C. LONGO, Vocabolario delle Costituzioni latine di Giustiniano, in BIDR 10 (18971898), pp. 79-80; E. VOLKMAR, Commissorius, in VIR, v. 1, Berlin, Georg Reiner, 1903, pp. 817820; H. HEUMANN - E. SECKEL, Handlexikon zu den Quellen des römischen Rechts, $10^{\mathrm{a}}$ ed., Graz, Akademische, 1891, pp. 80-81; P. E. HUSCHKE, Iurisprudentiae anteiustinianae quae supersuntin usum maxime accademicum, $5^{\mathrm{a}}$ ed., Leipzig, Teubner, 1886, p. 154; H. E. DIRKSEN, Committere, in Manuale latinatis fontium iuris civilis romanorum - Thesauri latinitatis epitome in usum tironum, Berolini, Dunckeri et Humblotii, 1837, pp. 166-167; F. CORRADINI (cur.), Totius latinitatis lexicon, Padova, Seminario, 1864, pp. 237-241.

${ }^{22}$ Cf. A. Doveri, Istituzioni di Dirito Romano, $2^{\text {a }}$ ed., v. 1, Firenze, Le monnier, 1866, p. 644; H. Donelli, Iurisconsulti et antecessoris Opera Omnia, t. 9, Lucae, Joannis Riccomini, 1766, pp. 1224-1225. Quanto ao vocábulo no período medieval - cf. D. DU CANGE, Committere, in Glossarium Mediae et Infimae Latinitatis, t. 2, Graz, Akademische Druck - U. Verlagsanstalt, 1954 (Unveränderter Nachdruck der Ausgabe Von 1883-1887), p. 449.

O entendimento da cláusula como sanção, contudo, implicaria um sentido pejorativo, do verbo committere, que poderia, com base em fragmentos como, e.g., Ner. 5 memb., D. 18, 3, 5, Lab. 5 post. a Iav. epitom., D. 19, 1, 51, 1, e Af. 9 quaest., D. 44, 3, 6, 1, presumir-se desconhecido à jurisprudência clássica mais antiga - cf. A. BISCARDI, La lex commissoria nel sistema delle garanzie reali, in Studi in onore di Emilio Betti, v. 2, Milano, Giuffrè, 1962, pp. 576577.

${ }^{23}$ Cf. H. DonelLI, Iurisconsulti et antecessoris Opera Omnia, t. 9, Lucae, Joannis Riccomini, 1766, p. 1225. Nas fontes - cf., e.g., Ulp. 14 ad ed., D. 4, 9, 1, 2 ("quamquam si ipse alicui e nautis committi iussit..."); Ulp. 4 fidei., D. 36, 1, 15 ("et recte ait non oportere sub incerto cautionis committere se aditioni hereditatis"); Gai. ad ed. urb. tit. de op. nov. nunt. D. 39, 1, 9 ("et post operis noui nuntiationem committunt se litigatores praetoriae iurisdictioni”); Ulp. 1 de decr. ab. ord. facient, D. 8, 9, 1 ( “...quibus se liberosque suos in aegritudine corporum committant”); Herm. 1 iur. epit., D. 1, 5, 13 ("Seruus in causa capitali fortunae iudici a domino commissus..."); Ulp. 7 de off. proc., D. 48, 3, 3 ( “... ut neque fideiussoribus neque militibus committi debeat...”); Paul. 33 ad ed., D. 18, 1, 34, 6 (“... si modo hoc solum arbitrio eius commissum sit...”); Paul. 17 ad ed., D. 5, 1, 12 (“...ceteris id committere videtur"); Scaev. 1 resp., D. 17, 1, 60, 4 ("Lucius Titius fratris filio commisit rerum suarum administrationem ita...”); Gai. 3 ad ed. prov., D. 3, 4, 1, 3 ("... nec ante rei suae administratio eis committi debeti..."); Ulp. 41 ad. ed., D. 37, 10, 5, 2 ("si velit adversarius committi sibi administrationem..."); Paul. 71 ad ed., D. 3, 3, 58 ("Procurator, cui generaliter libera administratio rerum commissa est..."); Ulp. 20 ad ed., D. 10, 3, 3, 13 ("Ibidem subiungit iudicem per arbitrium sibi ex hac actione commissum etiam exceptiones aestimare...”); Ulp. 3 op., D. 50, 9, 1 ("Medicorum intra numerum praefinitum constituendorum arbitrium non praesidi provinciae commissum est...”); Paul. sing. de poen. mil., D. 49, 16, 14, 1 (“...si arma 
(iii) "transgredir" 24

(iv) "adimplir", "concluir" 25 ;

(v) "unir", "juntar" (um elemento acessório a outro principal) ${ }^{26}$.

Parece ser acertada a decisão de A. BuRDESE ${ }^{27}$ ao se filiar a esta

última corrente. A principal dificuldade para que se compreenda a posição do autor, todavia, está em se desfazer de conceitos modernos e retroceder à muito mais abrangente construção romana de $l e x^{28}$.

militi commisit non suo tempore”); Af. 8 quaest., D. 47, 2, 62, 7 ("ceterum si ipse ultro ei custodiam argenti forte vel nummorum commiserit..."); Ulp. 31 ad Sab., D. 23, 3, 9, 3 ("et si custodia marito committitur...”); Ulp. 2 de off. proc., D. 48, 3, 1 (“... utrum in carcerem recipienda sit persona na militi tradenda vel fideiussoribus commitenda vel etiam sibi”); Mod. 4 de poen., D. 48, 3, 14 pr. (“... qui eam ei commisit”); Mod. 4 de poen., D. 48, 3, 14, 1 (“... sed duobus custodia committenda est”).

${ }^{24}$ Cf. D. Du CANGE, Committere cit. (nt. supra), pp. 449-450.

${ }^{25}$ Cf. H. DONELLI, Iurisconsulti et antecessoris cit. (nt. 23 supra), p. 1225.

${ }^{26}$ Cf. A. BuRDESE, "Lex commissoria" e "ius vendendi" nella fiducia e nel pignus, Torino, Giappichelli, s.d., p. 14; P. F. GIRARD, Manuel élémentaire de droit romain, Paris, A. Rousseau, 1906, p. 815; A. ERNOUT - A. MEILlet, Comes, in Dictionnaire cit. (nt. 20 supra), p. 135.

Este seria o sentido etimológico mais primitivo da palavra, não podendo desconsiderar, contudo, diversas outras transformações posteriormente apresentadas - cf. A. BURDESE, "Lex commissoria" cit. (nt. 26), p. 14.

De fato, a escolha parece ser bastante razoável, sobretudo se a confrontamos com o

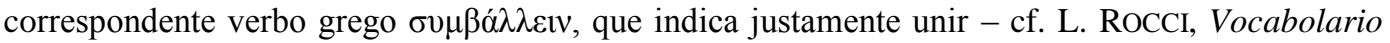
Greco-Italiano, 39a ed., Roma, Dante Alighieri, 2005, p. 1732.

Neste diapasão, importa ressaltar que já Cícero, em Pro Flacco, 21, e Ad fam., 13, 56, 2 , utiliza o verbo committere, para se referir à hypotheca grega, que já importaria, independente da lex commissoria, a faculdade pelo credor insatisfeito de apropriar-se da coisa sobre a qual é constituída - cf. A. PERNICE, Labeo - römisches Privatrecht im ersten Jahrhunderte der Kaiserzeit III, $2^{\text {a }}$ ed., Halle, Niemeyer, 1895, pp. 141-2; N. HERZEN, Origine de l'hypothèque romaine, Paris, L. E. Bosch et Filius, 1899, pp. 50 e ss; E. CostA, Cicerone Giuresconsulto, v. 1, Bologna, Zanichelli, 1927, pp. 140-141; W. ERBE, Die Fiducia im römischen Recht, Weimar, Hermann Böhlaus Nachf, 1940, p. 819.

Sobre a relação da obra de Cícero com os gregos - cf., especialmente, J. P. MAHAFFY, The silver age of the Greek world, Chicago-London, Elibron Classics, 1906, pp. 144 e ss.

27 "Lex commissoria”" cit. (nt. 26 supra), p. 15.

28 Atendendo às regras gerais, a palavra também era usada acompanhada de alguma especificação que lhe colocasse em evidência a origem, o conteúdo ou determinadas características (e.g., leges consulares, tribuniciae, decemvirales, sumptauariae, frumentariae, sacratae) quando não se optasse pelo uso adjetivado do nome do magistrado rogante (e.g., lex Acilia, Cornelia, Falcidia, Villia etc) .

Sobre as origens e diversas acepções da palavra lex - cf., especialmente, M. E. C. CLARK, Jus and lex, in Mélanges Fitting, t. 1, Montpellier, Société anonyme de l'imprimerie générale du midi, 1907, pp. 243-253; G. BroggINI, Ius lexque esto, in Coniectanea - Studi di Diritto Romano, Milano, Giuffrè, 1966, pp. 55-81; G. TIBILETTI, Lex, in Dizionario Epigrafico di Antichità Romane, v. 4, fasc. 22-25, Roma, Istituto italiano per la storia antica, s.d., pp. 702-707; Sulle 'leges' romane, in Studi in onore di Pietro de Francisci, v. 4, Milano, Giuffrè, 1955, pp. 595-621; M. KASER, Lex und ius civile, in Deutsche Landesreferate zum VII. Internationalen Kongress für Rechtsvergleichng in Uppsala, Berlin, Max-Planck Institut, 1967, pp. 3-21; B. BIONDI, Lex e ius, in BIDR 47 (1964), p. 31 e ss. 
Como lembra F. SERRAO ${ }^{29}$, no campo das relações jurídicas privadas $^{30}$, não é raro que lex vá além de sua mais conhecida e aceita definição em direito positivo, qual seja, "regulamentação", e seja utilizada também para indicar uma cláusula estabelecida concretamente ${ }^{31}$.

Neste último caso, em que se aperfeiçoa mediante um acordo de vontades, apresenta o mesmo caráter objetivamente vinculante de uma regra posta - vinculante, mas não autoritário ${ }^{32}$. Afinal, é estabelecida por partes que se encontram em um mesmo plano hierárquico.

Trata-se aqui, portanto, de uma das diversas possíveis manifestações do "Bindung" mommseniano, oportunamente interpretado por B. BIONDI ${ }^{33}$ como sendo o ato "voluntariamente vinculante" - sem que nesta expressão, portanto, possa ser apontada qualquer contradição - no âmbito da convivência social.

Em outras palavras, o termo lex, aplicado ao instituto, não era utilizada no sentido próprio e rigoroso de lex, ou seja, de norma jurídica de caráter geral e abstrato, imposta por uma autoridade coatora. Mais especificamente, consolidava-se como expressão da autonomia contratual das partes, na forma de convenção acessória capaz de modificar a eficácia do negócio principal ${ }^{34}$.

Daí porque entender que a designação lex aqui corresponderia à figura de um pacto adjeto $^{35}$, categoria bastante particular dos pacta romanos cuja existência, grosso modo, justifica-se por modificar os efeitos típicos dos diversos

${ }^{29}$ Legge (dir. rom.), in ED 23 (1973), p. 795.

30 Em última medida, na esfera privada, conceito e termo ainda hoje sobrevivem, especialmente quando se afirma que o contrato, entendido como acordo de vontades, ressalvadas, obviamente, suas peculiaridades, é lei ou tem força de lei (no sentido que as partes são vinculadas, como todos os homens são vinculados pela lei) - cf. B. BIONDI, Lex e ius cit. (nt. 28 supra), p. 47.

${ }^{31}$ Contra, P. FrEzZA, para o qual o significado lex não comporta pluralidades semânticas, referindo-se sempre a um preceito objetivamente vinculante e unilateralmente imposto - cf. Preistoria e storia della “lex” pubblica, in BIDR 35 (1956), p. 66.

${ }^{32}$ Cf. B. BIONDI, Lex e ius cit. (nt. 28 supra), p. 47.

${ }^{33}$ Lex e ius cit. (nt. 28 supra), p. 44.

${ }^{34}$ Inclusive, M. E. C. CLARK chegou a entender - sem que, contudo, encontrasse apoio nas fontes - que a origem do pacto se encontra em uma lex rei suae dicta - cf. Jus and lex cit. (nt. 28 supra), p. 247.

${ }^{35}$ Cf. B. BIONDI, Lex e ius cit. (nt. 28 supra), p. 47. 
tipos contratuais e tem por fundamento o "convenire" existência autônoma, mas depende da existência de um negócio principal ${ }^{37}$.

Para P. F. GIRARD ${ }^{38}$, inclusive, tal aplicação da forma adjetivada do verbo "committere", juntamente ao substantivo "lex", já revelaria um forte indício de que o instituto tenha tido $a b$ origine natureza de condição suspensiva. Deste assunto, contudo, trataremos mais adiante ${ }^{39}$.

De qualquer modo, certo é que o assunto está longe de ser pacífico. Nas principais traduções feitas ao Digesto, e.g., traduz-se o título 3 do livro 18:

(i) de modo literal $^{40}$;

(ii) como confisco ${ }^{41}$;

(iii) como reserva ${ }^{42}$;

(iv) de forma livre, buscando explicar a expressão ${ }^{43}$.

A fim de preservar as peculiaridades concernentes à lex commissoria da compra e venda e à lex commissoria aplicada aos direitos reais de garantia, e também para evitar o risco de incorrer em imprecisões terminológicas, optaremos neste trabalho pela simples utilização da expressão lex commissoria, forma como vem tratada nas fontes.

${ }^{36}$ Cf. G. Melillo, Patti (storia), in ED 32 (1982), p. 490.

37 A evolução da disciplina dos pacta, já no período pós-clássico, é guiada por uma crescente simplificação - seja das estruturas negociais, seja do processo - que, naturalmente, se de um lado tende à homogenização de pactum e contractus, de outro utiliza as diversas experiências pretorianas em direção da máxima funcionalidade dos negócios. Para tanto, a categoria de causa, entendida como razão econômica, e o crescente peso da voluntas em relação à forma são as razões de fundo da evolução - cf. G. Melillo, Patti (storia) cit. (nt. 36 supra), p. 493.

${ }^{38}$ Manuel élémentaire cit. (nt. 26 supra), p. 815.

${ }^{39}$ Cf. II. 2. 2.

${ }^{40}$ Cf. D’ORs et al., El Digesto de Justiniano I (constituciones preliminares y libros 1-19), Pamplona, Aranzadi, 1968, p. 671 ( "clausula comisoria"); I. L. GARCIA DEL CORRAL, Cuerpo de derecho civil romano I (Instituta - Digesto), Barcelona, Molinas, 1889, p. 906 ("pacto de la ley commissoria"); G. Vignali (coord.), Corpo del diritto corredato delle note di Dionisio Gotofredo e di C. E. Freiesleben altrimenti Ferromontano III (Digesto II), Napoli, Vincenzo Pezzutti, 1856, p. 1179 ("legge commissoria"); H. HULOT - J. F. BERTHELOT, Les cinquantes livres du Digeste ou Pandectes de l'empereur Justinien II, Metz, Behmer et Lamort, 1804, p. 564 ("de la clause résolutoire").

41 Cf. A. WATSON (ed.), The Digest of Justinian II, Philadelphia, University of Pennyslvania, 1998, p. 157 ("the forfeiture clause").

${ }^{42}$ Cf. R. Zimmermann et al., Corpus Iuris Civilis III - Digesten 11-20, Berlin, Mueller C. F, 1999, p. 356 ( “Auflösungsvorbehalt”).

${ }^{43}$ Cf. E. OtTO - B. SChILling - C. F. F. Sintenis, Das Corpus Juris Civilis, v. 3, Leipzig, Focke, 1831, p. 132 ("Nebenvertrage des Verfalls"). 
Em regra, sempre que se fizer menção simplesmente a "lex commissoria”, estaremos nos referindo àquela correspondente aos direitos reais de garantia - objeto de nosso estudo, sendo que a pertinente indicação será feita no caso da venda.

Por fim, neste primeiro momento, mais do que pertinente, faz-se necessário apresentar um conceito aproximado a que corresponde a lex commissoria, possibilitando uma melhor análise do instituto. Trata-se de conceito cujo conteúdo, obviamente, será melhor elucidado ao longo do presente trabalho.

Assim, para possibilitar, desde já, uma maior familiaridade com o tema, pode-se conceituar a lex commissoria como uma espécie romana de pacto acessório com eficácia real, que, após o inadimplemento da obrigação principal, importa para o credor insatisfeito a faculdade de conservar para si, na condição de proprietário, a coisa entregue em garantia.

\subsection{ORIGEM}

\subsubsection{NA FIDUCIA CUM CREDITORE}

Não obstante o ataque de W. ERBE ${ }^{44}$ à tese de que a fiducia tenha sido a mais antiga forma de garantia real ${ }^{45}$ conhecida pelo direito romano, por entender sua estrutura incompatível com tempos muito remotos, de modo geral, continua ela largamente aceita entre os autores ${ }^{46}$ que se ocuparam do tema.

\footnotetext{
${ }^{44}$ Die Fiducia cit. (nt. 26 supra), pp. 12-13.

${ }^{45}$ Sobre a crítica de que a fiducia cum creditore não possa ser definida como direito real de garantia, por comportar a definitiva transferência da propriedade, ainda que desenvolva análoga função econômica - cf., especialmente, P. LAMBRINI, Lineamenti storico-dogmatici della fiducia cum creditore, in La garanzia nella prospettiva storico-comparistica, $1^{\mathrm{a}}$ ed., Salisburg, Iustitiam Colimus, 2001, p. 257.

${ }^{46}$ Cf., entre outros, A. ASCOLI, , Le origini dell'ipoteca e l'interdetto salviano, Livorno, Raff. Giusti, 1887, pp. 2-3; C. Longo, Corso di diritto romano - La fiducia, $1^{\mathrm{a}}$ ed., Milano, CEDAM, 1946, p. 5; P. LAMBRINI, Lineamenti cit. (nt. 45 supra), pp. 257-258; P. FREZZA, Le garanzie delle obbligazioni - Corso di diritto romano, v. 2, Padova, CEDAM, pp. 4-5 ; P.
} 
Dentre os principais argumentos contrários ao pensamento do mencionado jurista alemão, está aquele que opõe a forma agier (= agi), apresentada por Cícero ${ }^{47}$ em De off. 3, 17, 70, à arcaica forma testarier (= testari) encontrada em um fragmento das XII Tábuas ${ }^{48}$.

A comparação de tais construções, cujas raízes seriam encontradas em tempos mais remotos do ordenamento romano, ganha ainda maior relavância na medida em que, na passagem ciceroniana onde a forma é empregada, se apresenta uma célebre expressão, comumente relacionada aos bonae fidei iudicia. Trata-se do "ut inter bonos bene agier oportet et sine fraudatione":

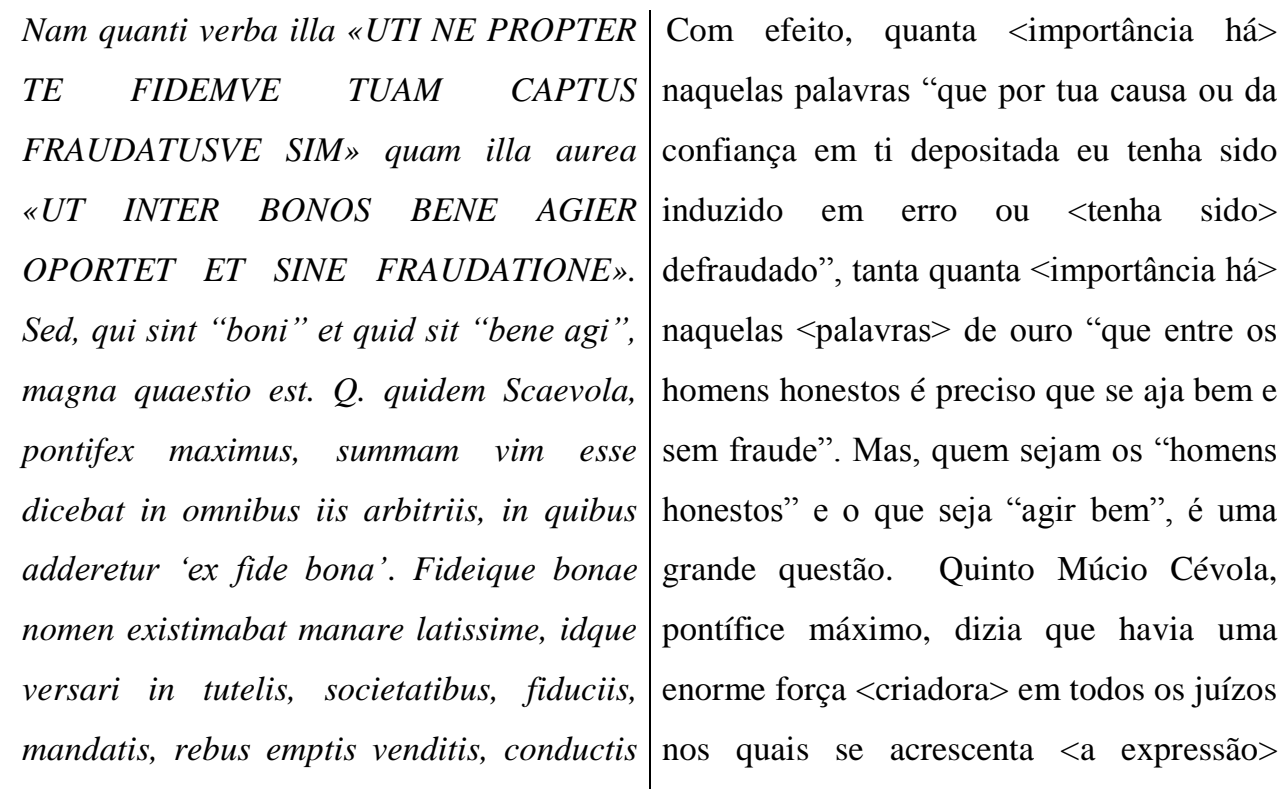

FUENTESECA, Líneas generales de la "fiducia cum creditore", in Derecho romano de obligationes, Madrid, Centro de Estudios Ramón Araces, 1993, p. 387. A respeito da origem da fidúcia, vide também A. WATSON, The Origins of Fiducia, in SZ 79 (1972), p. 329.

Pela prevalência da fiducia cum amico como mais antiga garantia real - cf. A. Ascoli, Le origini cit. (nt. 46 supra), pp. 2-3; C. LonGO, Corso di diritto romano cit. (nt. 46 supra), p. 5; P. LAMBRINI, Lineamenti cit. (nt. 45 supra), pp. 257-258; P. FrEZZA, Le garanzie cit. (nt. 46 supra), pp. $4-5$; P. FUENTESECA, Líneas generales cit. (nt. 46 supra), p. 387.

${ }^{47}$ Do mesmo autor, também há menção à célebre fórmula, com o uso da mencionada forma “agier” em De Off. 3, 15, 61 ( “...in arbitrio rei uxoriae melivs aeqvivs, in fiducia vt inter bonos bene agier..."); Ad fam. 7, 12 (“Ubi porro illa erit formula fiduciae: ut inter bonos bene agier oportet?”); Top. 17, $66 \quad$ ("In omnibus igitur eis iudiciis, in quibus ex fide bona est additum, ubi vero etiam ut inter bonos bene agier oportet in primisque in arbitrio rei uxoriae...").

Para uma mais ampla abordagem da biografia e obra do autor - cf., de modo geral, E. Costa, Cicerone giuresconsulto I e II, $2^{\mathrm{a}}$ ed., Bologna, Zanichelli, 1927, pp. 1 e ss.

${ }^{48}$ L. XII Tab., 8, 22 ("Qui se sierit testarier libripensve fuerit, ni testimonium fatiatur, inprobus intestabilisque esto"). 


\begin{tabular}{l|l} 
locatis, quibus vitae societas contineretur; & "segundo a boa-fé". Ele <,Quinto Múcio \\
in iis magni esse iudicis statuere, & Cévola,> entendia que o conceito de boa-fé \\
praesertim cum in plerisque essent iudicia & se manifesta muito amplamente e isso se \\
contraria, quid quemque cuique praestare & reflete nas tutelas, nas sociedades, nos atos \\
oporteret $^{49}$ & fiduciários, nos mandatos, nas compras e \\
vendas, nas locações, nas quais é contida a & comunhão de vida <entre os homens>: \\
nesses juízos é <cabível a um> grande juiz \\
estabelecer quanto cada parte deve prestar a \\
outra.
\end{tabular}

Por isso, inclusive, se deveria considerar fiduciário o negócio: Até o advento da actio fiduciae $e^{50}$, ao fiduciante restava apenas confiar na bona fides ${ }^{51}$

${ }^{49}$ Emprega-se aqui a mais recente edição crítica da obra, de R. R. MARCHESE- G. PICONE, Marco Tullio Cicerone - De officiis - Quel che è giusto fare, Torino, Einaudi, 2012, p. 301, confrontada com o estudo clássico de F. PITTERI, M. Tullii Ciceronis Opera Quae Supersunt Omnia, v. 10, Venetiis, Studio Bibliografico Benacense, 1731, pp. 242-243.

${ }^{50}$ A fonte mais preciosa para a reconstrução da natureza e da estrutura da actio fiduciae está indubitavelmente em Cícero, sobretudo em De off., 3, 17, 70. Há, contudo, outras notícias da actio fiduciae em Gaio e no Digesto, especialmente em Gai. 4, 62 e Ulp. 28 ad Sab. D. 18, 2, 10.

A questão quanto à exata data de origem da ação, contudo, costuma dividir grande parte da doutrina. O mais provável, para a maioria, é que a actio fiduciae já existisse logo na primeira metade do II século a.C., período em que se vislumbra uma proliferação de novas ações, devidas em grande parte à aplicação inter cives do novo procedimento formular por parte do pretor urbano, antes da Lei Ebúcia - cf., mais recentemente, N. BELLOCCI, La tutela della fiducia dalle origini alla fine della repubblica, Siena, Universitá di Siena, 1971, pp. 42-43; C. LoNGO, Corso di diritto romano cit. (nt. 46 supra), pp. 72-73; P. FUENTESECA, Líneas generales cit. (nt. 46 supra), p. 419; Bonfante, Istituzioni di diritto romano, $10^{\mathrm{a}}$ ed., Torino, G. Giappichelli, 1946, p. 472; P. LAMBRINI, Lineamenti cit. (nt. 30 supra), p. 269, P. FREZZA, Le garanzie cit. (nt. 46 supra), p. 65. Contra - cf. R. AMBrosino, La legis actio sacramento in personam e la protezione giuridica dei rapporti fiduciari, in Studi in onore di Vincenzo Arangio-Ruiz II , v. 2, $1^{\text {a }}$ ed., Napoli, Giuffrè, 1952, pp. 251-268; P. OERTMANn, Die Fiducia im römischen Privatrecht, Berlin, Guttentag, 1890, p. 260; O. LENEL, Das Edictum perpetuum (ein Versuch zu dessen Wiederherstellung), Leipzig, Tauchnitz, 1883. A tese de O. LENEL sobre a existência de uma legis actio fiduciae in factum foi parcialmente retomada por A. WATSON, que sustenta que, ao lado da formal legis actio fiduciae, tenha existido também uma legis actio fiduciae in factum - cf. The origins cit. (nt. 46 supra), pp. 332-335.

${ }^{51}$ Nesse diapasão, vale tecer alguns breves comentários sobre a fides, cujo conceito é de grande valia para uma melhor compreensão do instituto.

Como afirma F. SCHULZ, a fides era definida na Antiguidade como a existência de palavra dada ("fit quod dicitur"), uma das facetas da constantia (invariabilidade), que na visão dos romanos perfaria a virtude central do homem - cf. Prinzipien des römischen Rechts, 1934, trad. it. de V. Arangio-Ruiz, I principii del diritto romano, $1^{a}$ ed., Firenze, Sansori, 1946, pp. 193-194. E as fontes literárias parecem confirmar tal relação, tão cara aos romanos, entre a noção em tela e a manutenção da palavra dada - cf. D. NöRR, "Fides" im römischen Völkerrecht, 1931, trad. esp. de R. Domingo, La fides em el derecho internacional romano, $1^{\mathrm{a}}$ ed., Madrid, Fundacion Seminario de Derecho Romano Urscino Alvares, 1996, p. 18. Assim, e.g., a fides é apresentada por Cícero 
do fiduciário, estando impossibilitado de obter uma devolução compulsória ou de coagir a parte contrária a dar à coisa a destinação convencionada.

Ainda que, como afirma P. FrEZZA ${ }^{52}$, a contraposição dos dois textos não seja suficiente para justificar a inequívoca existência de uma ação específica ao instituto já em período bastante remoto $^{53}$, a presença da arcaica forma ciceroniana agier como parte do formulário da primitiva ação de fiducia $^{54}$ poderia,

como a fundação da iustitia, que demandava a verdade e a fidelidade a promessas e acordos - cf. De off. 1, 7, 23.

É curioso notar que a responsabilidade em relação ao vínculo era tão séria, que o mesmo Cícero afirma que a verdade e a fidelidade a promessas, bem como a acordos e juramentos, deveria ser observada ainda quando extraída com o uso de violência - cf. De off. 3, 30, 110. Posteriormente, deixou a fides de ser mera lealdade ao acordado para converter-se em um modo geral de comportamento, seja este ético, moral ou jurídico - cf. D. NöRR, "Fides" cit. (nt. 36 supra), p. 16.

Mais do que isso, também seria ela a base da bona fides, princípio jurídico que somente em um momento posterior seria introduzido no direito romano, por obra dos pretores. Essa noção jurídica possibilitava a mensuração de manifestações de regularidade nas condutas, de modo a tornar previsíveis as soluções para conflitos futuros, permitindo que, a fim de se obter um equilíbrio nas relações jurídicas, se tratasse o igual por igual e o diferente de modo diferente, de acordo com a medida da variação capaz de suscitar consenso na comunidade - cf. A. M. R. MENEZEs CoRDEIRO, Da Boa fé no direito civil, Coimbra, Almedina, 2001, p. 18.

Tratar-se-ia, portanto, do dever genérico de comportar-se com retidão nas relações jurídicas, que poderia ser reportado aos ideais da fides, notadamente em relação ao respeito à palavra dada, com o qual mantinha uma conexão bastante estreita. Dessa forma, possibilitava-se a prevalência de simples acordos sobre outros valores, essencialmente formais - cf. M. TALAMANCA, La "bona fides" nei giuristi romano - "Leerformel" e valori dell'ordenamento, in L. Garofalo (org.), Il ruolo della buona fede oggetiva nell'esperienza giuridica storica e contemporanea, v. 2, Padova, CEDAM, 2003, p. 46.

Conforme P. BONFANTE, resta claro que nas diversas relações jurídicas o comportamento de lisura e lealdade, compreendido na boa-fé objetiva romana, deve se referir a um objeto determinado e diverso. O dever abstrato e geral de conduta conforme o homem médio deve, em cada relação, explicar-se em algum dever concreto e particular. Assim, a noção do que deve ser compreendido como bona fides em cada situação seria mesurada em relação às particularidades e expectativas da sociedade, e remetida em sua extensão à apreciação do juiz, o qual teria por tarefa interpretar tal noção e aplicá-la ao caso concreto - cf. Essenza della "bona fides" e suo raporto colla teoria dell'errore, in Scritti Giuridici Varii, v. 2, Torino, Unione Tipografico, 1916, pp. 718719.

Contudo, ainda que o estudo simultâneo dos institutos seja inevitável, para alguns autores o ideal para melhor compreender o instituto da fidúcia é mesmo esvaziá-la da fides, seu núcleo fundamental - cf., entre outros, P. FUENTESECA, Líneas generales cit. (nt. 46 supra), p. 388.

${ }^{52}$ Le garanzie delle obbligazioni cit. (nt. 46 supra), pp. 3-4.

${ }^{53}$ No mesmo sentido, N. BELOCCI, La tutela della fiducia dalle origini alla fine della repubblica, Siena, Universitá di Siena, 1971, p. 75; C. LONGO, Corso di diritto romano cit. (nt. 46 supra), p. 54. Contra, A. MANIGK, Fiducia, in RE 6 (1909), p. 2309; R. AMBRosino, La legis actio cit. (nt. 50 supra), p. 260; A. BURDESE, "Lex commissoria" cit. (nt. 26 supra), p. 58; P. Oertmann, Die Fiducia cit. (nt. 50 supra), pp. 260-261.

${ }^{54}$ Contra - cf. R. MONNIER, Manuel elémentaire de droit romain, v. 2, $5^{\mathrm{a}}$ ed., Paris, Domat Montchrestien 1947, p. 97. 
ao menos, ser considerada um valioso indício de que suas origens correspondem a um momento precedente ao próprio Quinto Múcio Cévola ${ }^{55}$.

Além disso, a própria estrutura da fórmula ${ }^{56}$ leva a doutrina ${ }^{57}$ a relacionar as manifestações negociais baseadas no elemento fiduciário às fases mais iniciais do pensamento jurídico romano ${ }^{58}$, pela utilização de um ato solene (mancipatio ou in iure cessio) com uma finalidade diversa (garantia) daquela que seria a sua própria (mera transferência da propriedade).

É o que se vê na da fórmula bética ${ }^{59}$. Nesta, a fiducia cum creditore é constituída mediante um negotium per aes et libram, no qual se realiza uma mancipatio fiduciae causa seguida de um pactum conventum ${ }^{60}$. Assim, na mencionada fórmula:

a) É prevista a mancipatio fidi fiduciae causa, por um preço simbólico (sestertio nummo I), tendo por objeto o fundus Baianus e o escravo chamado Midas:

${ }^{55}$ Ainda que o período temporal seja de grande importância para elucidar a questão, o autor não precisa a qual Quinto Múcio Cévola (em latim, Quintus Mucius Scaevola) faz referência: se ao pretor de 215 a.C., se ao cônsule de 117 a.C., ou, ainda, se ao cônsule, também pontífice máximo, de 95 a.C. Pela leitura do fragmento de Cícero, De off. 3, 17, 70, no entanto, a questão parece ser facilmente esclarecida.

Para uma breve descrição do papel dessas figuras históricas na sociedade romana - cf. M. J. GaRCía GARRIDO, Diccionario de jurisprudencia romana, $3^{\mathrm{a}}$ ed., Dykinson, Madrid, 2000 (reimpr.), p. 239-240.

${ }^{56}$ Para as complexas tentativas de reconstrução da conceptio da fórmula da ação - cf., especialmente, P. FREZZA, Le garanzie cit. (nt. 46 supra), p. 70.

${ }^{57}$ Cf., especialmente, A. AsCOLI, Le origini cit. (nt. 46 supra ), pp. 2-3; C. LONGO, Fiducia cum creditore, in Per Il XIV centenário della codificazione giustinianea, Pavia, 1934, p. 797; A. WATSON, The origins cit. (nt. 46 supra), pp. 332-335.

58 "Frequente nei diritti primitivi o poco svilupati" - cf. C. LONGO, Fiducia cum creditore cit. (nt. 57 supra), p. 797. 297.

${ }^{59}$ Cf. V. ARANGiO-RUIZ, Fontes iuris Romani antejustiniani, III, Firenze, 1943, pp. 295-

${ }^{60}$ Segundo o entendimento geral, a tábua contém um formulário ou modelo de alienação fiduciária, a ser preenchido com a indicação do crédito concreto, seja ele presente ou futuro Cf., especialmente, P. FUENTESECA, Lineas generales cit. (nt. 46 supra), p. 392; Cf. N. BELlOCCI, La struttura del negozio della fiducia nell'epoca repubblicana - Le nuncupationes, $1^{\text {a }}$ ed., v. 1, Napoli, Eugenio Jovene, 1979, p. 23; C. LoNGO, Corso di diritto romano cit. (nt. 46 supra), pp. 67-68. A Fórmula Bética estabelecia a possibilidade de se garantir com a fiducia cum creditore não apenas créditos presentes, mas também futuros e condicionais ou a termo. C. LONGO,contudo , não crê na viabilidade de que a fidúcia seja garantida por créditos eventuais e indeterminados, uma vez que, em tal hipótese, ter-se-ia uma "fidúcia eterna", caso o crédito não viesse a se concretizar cf. Corso di diritto romano cit. (nt. 46 supra), p. 34. 
Dama L. Titi ser(vus) fundum Baianum, qui est in agro qui | Veneriensis vocatur, pago Olbensi, uti optumus maxumusq(ue)| esset, (sestertio) n(ummo) I et hominem Midam (sestertio) n(ummo) I fidi fiduciae causa man|cipio accepit ab L Baianio, libripende antest(ato). Adfines fundo | dixit $L$. Baianius L. Titium et C. Seium et populum et si quos dicere oportet. $\|(. .$.
Dama, escravo de L. Tício, aceita <por meio de uma> mancipatio fidi fiduciae causa assegurada por L. Baiano um terreno <de propriedade> de Baiano que está no campo denominado Veneriense, na aldeia Olbense, por " $\mathrm{x}$ " sestércios e o escravo Midas por " $y$ " sestercios, como se fossem livres de restrições, <estando presentes o> libripende e as testemunhas. Foi manifestado que L. Baiano, L. Ticio e C. Seio e a população são vizinhos ao terreno e convém citar aqueles <eventualmente>. | (...)

b) Ao ritus mancipationis é aposto um pactum conventum, entre o mancipio dans e o mancipio accipiens, pelo qual as coisas permaneceriam sujeitas ao vínculo fiduciário até que a dívida pecuniária fosse paga (... usque eo is fundus eaque mancipia fiduciae essent, donec ea omnis pecunica fidesve persoluta L. Titi soluta liberataue esset...):

(...) Pactum conventum factum est inter (...) Foi celebrado um pactum comventum Damam, L. Titti ser(vum), et L. entre Dama, escravo de L. Ticio, e L. Baian(ium), <uti> | quam pecuniam L. Baiano, para que este terreno e aquele $<$ Titius L.> Baian<i>o dedit dederit, escravo fossem <adquiridos em razão> da credidit crediderit, ex|pensumve tulit confiança, até que tivesse tido quitação <o tulerit, sive quid pro eo promisit crédito> de L. Ticio, ou tivessem sido pagos promiserit, | spopondit <spoponderit> ${ }^{61}$, e liberados todos os créditos, ou seja, aquele fideve quid sua esse iussit iusserit, usque eo is fundus | eaque mancipia fiducia $\langle e\rangle$ dinheiro que, a L. Baiano, L. Ticio essent, donec ea ominis pecunia fides||ve persoluta L. Titi soluta liberataque esse (...) entregou, depositou ou levou em <equivalente> valor, ou <do crédito> que prometeu para ele <,L. Baiano,> garantiu, ou que autorizou com fides (...)

61 Essas três formas de crédito pecuniário (pecunia data, stipulata e expensa lata), mencionadas na Fórmula Bética, também são apresentadas em Cícero, pro Rosc., 4, 13 e 5, 14. 
c) A não satisfação do crédito, por sua vez, implicaria a venda das coisas fiduciadas, de acordo com a vontade do credor ou seus herdeiros:

\begin{tabular}{|c|c|}
\hline $\begin{array}{l}\text { “(...) si pecunia sua qua|que die L.Titio } \\
\text { h(eredi)ve eius data soluta non esset, tum } \\
\text { uti eum | fundum eaque mancipia, sive } \\
\text { quae mancipia ex is <<vellet>> L. Titi|us } \\
\text { h(eres)ve eius vellet, ubi et quo die vellet, } \\
\text { pecunia praesenti | venderet (...)” }\end{array}$ & $\begin{array}{l}\text { (...) se o dinheiro não tivesse <sido> } \\
\text { entregue a L. Ticio ou a seus herdeiros no } \\
\text { termo <acordado>, então L. Ticio ou seus } \\
\text { herdeiros poderão vender este terreno e } \\
\text { aquele escravo ou apenas aquele escravo, } \\
\text { por venda à vista, quando e onde quiserem } \\
\text { (...) }\end{array}$ \\
\hline
\end{tabular}

C. LONGO $^{62}$ reforça a idéia trazida pela fonte ao lembrar que o antigo ius Quiritium, cujo dominium correspondente não era transmissível sob condição resolutiva $^{63}$, não conhecia outros direitos sobre a coisa além da propriedade e da servidão. Assim, o único poder jurídico autônomo sobre coisa própria que o devedor poderia ceder em garantia era justamente aquele relativo ao direito de propriedade $\mathrm{e}^{64}$.

$\mathrm{Na}$ fiducia cum creditore, uma parte (fiduciário) recebe de outra (fiduciante) ${ }^{65}$ a propriedade de uma coisa infungível ${ }^{66}$, obrigando-se, mediante um

${ }^{62}$ Corso di diritto romano cit. (nt. 46 supra), pp. 69-70.

${ }^{63}$ Cf., mais adiante, em II.2.4.

${ }^{64} \mathrm{O}$ credor fiduciário podia dispor da coisa recebida em garantia como qualquer proprietário, contando com a proteção proporcionada pela actio fiduciae. Seus atos de disposição também conservavam plena eficácia em relação a terceiros, inclusive, obviamente, em relação ao próprio fiduciante, que não dispunha, nesta situação específica, de qualquer meio de tutela que lhe permitisse, desde logo, a recuperação da coisa - cf., F.V. 18, que prevê a aplicabilidade da actio fiduciae: “... emptores inquietari, sed actione fiduciae..." (= ... os compradores são acionados, mas pela actio fiduciae...), e P.S. 2, 13, 6, que trata da proteção do herdeiro ou do terceiro que recebe a coisa em legado: "Si creditor rem fiduciae datam uni ex heredibus vel extraneo legaverit, adversus omnes heredes actio fiduciae competit" (= Se o credor lega a um de seus herdeiros ou a um terceiro a coisa fiduciada, a actio fiduciae é cabível contra todos os seus herdeiros).

${ }^{65} \mathrm{Na}$ verdade, os latinos utilizavam-se de expressões como "is oui fiduciam dedit" e "is qui fiduciam accepit”, ou indicavam, na fidúcia com objeto de garantia real, o alienante como "debitor' e o a outra parte como "creditor" - cf. C. LONGO, Corso di diritto romano cit. (nt. 46 supra ), p. 8 .

${ }^{66}$ Inversamente à maioria dos autores que dissertaram sobre o tema, que entenderam que apenas as coisas infungíveis que fossem res mancipi podiam ser objeto da fidúcia, C. LONGO é da opinião de que as res nec mancipi também podiam sê-lo - cf. Corso di diritto romano cit. (nt. 46 supra), p. 5. No mesmo sentido, P. LAMBRINI cit. (nt. 45 supra), p. 257.

Sobre a natureza dos créditos capazes de serem garantidos mediante fiducia, tem se que o instituto prestava-se, basicamente a garantir créditos de dinheiro - cf. Isidoro, Orig., 5, 25, 23: 
pacto autônomo, aposto à mancipatio ou à in iure cessio, a restituí-la, tão logo seja efetuado o pagamento da obrigação principal. Por conseqüiência, o eventual inadimplemento da obrigação principal resultaria na definitiva manutenção do direito real pleno por parte do credor fiduciário.

A propriedade fiduciária, nesse sentido, poderia ser caracterizada como um tipo singular de domínio: se, de um lado, ao domínio do fiduciário corresponde o normal direito de propriedade, de outro, na condição de credor, ele tem o exercício de suas faculdades indiretamente vinculado às obrigações assumidas com o fiduciante - obrigações essas que derivam da natureza de boa-fé do negócio.

Por fim, também a favor de que o instituto da fiducia já era conhecido em tempos bastante antigos, considera-se a exigência da transferência da propriedade fiduciária através, unicamente, das formalidades presentes na mancipatio ou na in iure cessio $^{67}$, modos derivados de aquisição da propriedade aos quais se ligava o pactum fiduciae. Nesse sentido, afasta-se a idéia de que a traditio possa ter se prestado a esse fim, pois:

a) não há qualquer testemunho nas fontes sobre um tipo de fiducia constituída por meio de traditio $^{68}$;

b) a decadência ${ }^{69}$ da fiducia cum creditore coincide com o desuso da in iure cessio e da mancipatio ${ }^{70}$;

\footnotetext{
"Fiduciae est, cum res aliqua sumendae pecuniae gratia vel mancipatur vel in iure ceditur" (= tem-se a fidúcia quando alguma coisa deve ser tomada de empréstimo em dinheiro, ou é vendida ou é cedida em direito). Esta, embora seja a mais conhecida definição (sobretudo porque a ela se referem os atos privados contidos nas mencionadas Formula Baetica e nas Tábuas Pompeianas), não deve ser entendida de forma restritiva - cf. C. LONGO, Fiducia cum creditore cit. (nt. 57 supra), p. 796.

${ }^{67}$ Apesar de conservar mesmo caráter acessório do penhor, a fiducia, por ser constituída através de um dos modos solenes e derivados de transferência da propriedade, não era invalidada, na hipótese em que fosse invalidada a obrigação garantida - cf. C. LONGO, Fiducia cum creditore cit. (nt. 57 supra), p. 797.

A mancipatio fiduciaria, vale lembrar, não outorga a possibilidade de alcançar o título de dominus ex iure Quiritium, o qual requer uma mancipatio emptionis causa, com um preço efetivamente pago ou devidamente garantido no ato negocial - cf. P. FUENTESECA, Líneas generales cit. (nt. 46 supra), p. 412.

${ }^{68} \mathrm{Cf}$. Se verá pouco mais adiante, a própria Tábula Baetica e a mancipatio pompeiana, importantes documentos para a compreensão da estrutura do instituto, trazem, por exemplo, a transferência da coisa dada em fiducia através da mancipatio.
} 
c) a traditio é modo causal - e não abstrato - de transferência da propriedade $^{71}$. Seria incompatível, portanto, com a estrutura da fiducia. É o que atesta Paulo em 31 ad ed. D. 41, 1, 31, $\mathrm{pr}^{72}$ :

${ }^{69}$ B. BIONDI lembra que a fiducia, nas práticas negociais de tempos mais antigos, exerce uma importantíssima função, que diminui à medida em que a ordem jurídica passa a conhecer novos negócios e são eliminadas algumas formalidades que não mais correspondiam às necessidades sociais - cf. Istituizioni di diritto romano, Milano, Giuffrè, 1946, p. 196.

${ }^{70} \mathrm{Cf}$. P. FREZZA, Le garanzie delle obbligazioni cit. (nt. 46 supra), p. 5.

71 A traditio era um ato não formal e, segundo a opinião majoritária, modo causal de transferência da propriedade - cf., dentre outros, E. BETTI, Sul carattere causale della 'traditio' classica - A proposito di studi recenti, in Studi Riccobono, v. 4, Palermo, 1936, p. 113; G. GROSSO, Fiducia (diritto romano), in ED 17 (1968), p. 385; M. KASER, Zur iusta causa traditionis', in BIDR 64 (1961), pp. 61-62.; F. BENEDEK, Die iusta causa tradiionis im römischen Recht, 1962, in Acta Juridica Academiae Scientiarum Hungaricae, t. 4, fasc. 1-2, Budapest, Akademai Kiado, 1991 (reimpr.), pp. 117-119; R. LAMBERTINI, In tema di iusta causa traditionis, in Fides Humanitas Ius - Studi in onore di Luigi Labruna, v. 4, Napoli, Editoriale Scientifica, 2007 , p. 2745. Isso porque, sendo a mera entrega de um bem, por si só, ambígua, seria sempre necessário indagar se o "significato economico" resultante do acordo estabelecido pelas partes teria efetivamente sua existência condicionada à transferência da propriedade da coisa (caso contrário, se a obtenção de tal significado não implicasse a necessária passagem da propriedade, o efeito translativo poderia então ser substituído por uma simples transferência da posse) - cf. C. A. CANNATA, "Traditio" causale e "traditio" astratta: uma precisazione storico-comparatistica, in Scritti in onore di Rodolfo Sacco, v. 1, Milano, 1994, pp. 157-158. M. TALAMANCA, nesse mesmo sentido, já definia a traditio como negócio a "causa variabile” - cf. Istituzioni di diritto romano, Milano, Giuffrè, 1990, pp. 211 e 437.

Assim, o objetivo de garantia da obrigação principal não é considerado suficiente a justificar uma transferência de propriedade como se verifica na fiducia cum creditore - cf. G. PUGLIESE, La simulazione nei negozi giuridici, Padova, CEDAM, 1938, p. 37.

${ }^{72}$ A inscriptio do texto, pertencente ao livro $31^{\circ}$, seria um irrefutável indício de que Paulo, na verdade, estaria se referindo ao instituto da fiducia - cf. O. LENEL, Quellenforschungen in den Edictcommentaren, in SZ 3 (1882), pp. 104 e ss.; Palingenesia iuris civilis (iuris consultorum reliquae quae Iustiniani Digestis continentur ceteraque iurisprudentiae civilis fragmenta minora secundum auctores et libros disposuit) I e II (1889), reimpr., Aalen, Scientia, 2000, p. 1027. Sobre a questão da importância da obra de O. LENEL para o estudo da fiducia - cf. nt. 72-73 infra. No mesmo sentido - cf. A. EHRHARDT, Justa causa traditionis - Eine untersuchung über den erwerb des eigentums nach römischem recht, Berlin und Leipzig, W. De Gruyter \& Co., pp. 134-135; G. SEGRÈ, Corso di diritto romano - Le obligazione personali e reali, Torino, Coop. Libri Del G.U.F., 1934, p. 39; FREZZA, Le garanzie delle obbligazioni cit. (nt. 31 supra), pp. 8-9.

P. DE FRANCISCI entende interpolado o texto - cf. Il trasferimento della proprietà, storia e critica di una dottrina, Roma, Lilotipo, 1924, pp. 152-153.

Um outro texto confrontável com Paul. 31 ad ed. D. 41, 1, 31, pr é Ulp. 71 ed., D. 39, 5, 18, 2: 


\begin{tabular}{l|lrl} 
Numquam nuda traditio transfert & A nua tradição nunca transfere o domínio, a \\
dominium, sed itta, si venditio aut aliqua & menos que tenha sido precedida a venda ou \\
alia iusta causa praecesserit, propter & alguma justa causa pela qual seguisse a \\
quam traditio sequeretur. & entrega.
\end{tabular}

d) tendo em vista o mencionado no item anterior, pode-se concluir que o caráter abstrato da mancipaito e da in iure cessio é fundamental para que, ao lado desses atos formais, se introduza um pacto informal ${ }^{73}$ através do qual se atinge efeito diverso daquele que seria a natural transferência definitiva e irreversível da propriedade ${ }^{74}$.

Tais considerações são importantes ao nosso estudo já que não raras são as vezes em que a origem da lex commissoria vem atrelada ao instituto, mais especificamente à sua forma "cum creditore",75.

\begin{tabular}{|c|c|}
\hline $\begin{array}{l}\text { Idem Aristo ait, si donationis fiduciae causa } \\
\text { in hoc tradatur mancipio detur servus, ut } \\
\text { post quinquennium manumittatur, sit autem } \\
\text { alienus, posse dubitari an usucapiatur, quia } \\
\text { aliquid donationis interveniret. Et hoc } \\
\text { genus quaestionis in mortis causa } \\
\text { donationubus versari Pomponius ait et } \\
\text { magis putat ut, si ita donetur, ut post } \\
\text { quinquennium manumittatur, posse dici } \\
\text { usucapionem sequi. }\end{array}$ & $\begin{array}{l}\text { Diz o mesmo Aristão, que se por uma } \\
\text { doação <feita> por causa da fidúcia se } \\
\text { entregou um escravo para que fosse } \\
\text { manumitido depois de um quinquênio, } \\
\text { porém o escravo era de outro, se podia } \\
\text { duvidar se <o escravo> era usucapido, } \\
\text { porque teria mediado uma espécie de } \\
\text { doação. E diz Pompônio, que este típo de } \\
\text { dúvida tem lugar nas doações causadas em } \\
\text { função da morte, e julga mais correto que } \\
\text { se se tenha realizado a doação para que seja } \\
\text { manumitido depois de um quinquênio, se } \\
\text { pode dizer que se verifica a usucapião. }\end{array}$ \\
\hline
\end{tabular}

O conteúdo desse fragmento torna-se relevante na medida em que o pensamento de Aristão e de Pompônio, que Ulpiano seguia em matéria de negotium mixtum cum donatione, se reconstrói segundo a seguinte linha: a usucapião do servo, mancipado fiduciae causa, ut manumittatur post quinquennium, se verifica, não obstante a causa fiduciae. No entanto, isso apenas é possível uma vez que, com a causa fiduciae (que não conduz à usucapião), concorre a causa donationis (que é, por outro lado, iusta causa usucapionis). Disso se pode concluir que a fiducia, como não é iusta causa traditionis, tampouco seria iusta causa usucapionis - cf., nesse sentido, W. ERBE, Die Fiducia cit. (nt. 26 supra), pp. 12-13; O. GEIB, 'Actio fiduciae' und Realvertrag, in SZ 8 (1887), p. 113. Contra, H. KRELLER, 'Formula fiduciae' und Pfandedikt, in SZ 62 (1942), p. 197.

${ }^{73}$ Contra, A. AsCOLI, Le origini cit. (nt. 46 supra ), p. 6.

74 Cf. P. FrezzA, que denomina tal situação de "dissonanza” - cf. Le garanzie delle obbligazioni cit. (nt. 46 supra), p. 10.

${ }^{75}$ Tinha-se a fiducia cum amico toda vez que uma pessoa transferisse a outra o domínio de uma coisa somente com o escopo de custódia, guarda ou gozo gratuitos e temporários - cf. B. BIONDI, Istituizioni cit. (nt. 69 supra), p. 197. 
A. SACCHI $^{76}$ enumera algumas semelhanças que, segundo ele, tornariam compreensível o nexo histórico entre os institutos:

a) supõem a tradição material da coisa, acompanhada ou não da formalidade translativa de domínio ${ }^{77}$;

b) são pactos acessórios ${ }^{78}$ ao contrato principal;

c) podem produzir a nulidade do contrato principal, o que poderia ocorrer de dois modos: não dando lugar à novação do título de posse no cessionário da coisa, ou verificando-se a condição fixada para a resolução do contrato principal por força do pacto comissório ${ }^{79}$.

De qualquer modo, é certo que vincular as origens da lex commissoria a esse instituto é tarefa bastante árdua. Isso porque, como lembra P. LAMBRINI ${ }^{80}$, as poucas fontes diretas ${ }^{81}$ e os documentos muitas vezes fragmentários não oferecem sua inteira disciplina, de modo que a doutrina pôde abandonar-se às mais variadas especulações relativamente à sua origem, estrutura e efeitos.

Da fiducia cum creditore $^{82}$ não existe qualquer menção expressa na compilação justinianéia. No entanto, graças aos estudos palingenéticos de O.

Por essa razão, o estudo da lex commissoria se faz importante, exclusivamente, à fiducia cum creditore. Sobre a impossibilidade de aplicação da fiducia cum amico à lex comissoria - cf. P. FREZZA, Le garanzie delle obbligazioni cit. (nt. 46 supra), pp. 42-43.

${ }^{76}$ Sul patto commissorio in diritto romano, in Archivio Giuridico 55 (1865), pp. 213-215.

77 Complementarmente ao já afirmado sobre a impossibilidade de que a traditio possa constituir meio apto à transferência da coisa dada em garantia, temos que Gaio apenas mencionava a possibilidade de que tal processo se verificasse por intermédio da mancipatio ou da in iure cessio - cf. 2, 59: "Adhuc etiam ex aliis causis sciens quisque rem alienam usucapit: nam qui rem alicui fiduciae causa mancipio dederit uel in iure cesserit, si eandem ipse possederit, potest usucapere, anno scilicet, non solum res thobilis sed et soli si sit. quoe species usucapionis dicitur usureceptio, quia id, quod aliquando habuimus, recipimus per usucapionem" (= Podemos usucapir coisa notoriamente alheia, mesmo que por outras causas, pois quem cedeu uma coisa a outrem, por mancipatio ou por in iure cessio, a título de fiducia, se vier a possuí-la, pode usucapir dentro de um ano, ainda que a coisa seja fixa ao solo, usucapião esta denominada de usureceptio, por cobrarmos novamente, por usucapião, aquilo que tinha sido nosso) .

${ }^{78} \mathrm{O}$ autor, neste ponto, parece ignorar a autonomia inerente à fiducia, confundindo-a com o pactum fiduciae - este sim, aposto ao negócio com o objetivo de reduzir o rigor com que se moldava o instituto mais arcaico.

${ }^{79} \mathrm{Cf}$., nesse sentido, item II.2.2.

${ }^{80}$ Lineamenti cit. (nt. 45 supra), p. 259.

${ }^{81}$ Cf., além da Tabula Baetica e da Mancipatio Pompeiana, Gai. 2, 60; Gai. 3, 201; P.S. 2,13; F.V. 9; Coll. 10, 2,2.

${ }^{82} \mathrm{Na}$ realidade, o escopo, pelo qual era finalizada a propriedade transferida ao proprietário, poderia ser o mais variado; o grande valor da fiducia, como hoje do trust, é de ser um instituto extremamente flexível e aberto aos empregos mais diversos em todos os campos. No presente 
LENEL $^{83}$, foi possível relacionar ao instituto, com certa segurança, significativo número de trechos contidos no Digesto justinianeu.

Reconstruindo a sistemática das obras clássicas a partir das inscriptiones contidas no Digesto, o autor notou que a matéria do penhor teria sido tratada duas vezes, em livros diversos e não contíguos ${ }^{84}$, sem que, portanto, fosse possível identificar uma lógica compatível com o sistema segundo o qual a matéria vinha se desenvolvendo.

A análise dos fragmentos dos comentários de Gaio, Paulo e Ulpiano, metodicamente conduzida para os livros 9, 29, 28, e 10,31, 30, respectivamente,

estudo, vale salientar, aparece a fiducia desvinculada de sua originária aplicação no direito de família (coemptio fiduciae causa) e no direito das sucessões (testamentum per aes et libram) .

A chamada coemptio era o ato com o qual o efeito translativo do matrimônio se adquiria sobre a esposa, não matrimonii, mas fiduciae causa, Assim, quando a mulher quisesse evitar a tutela do agnato, realizava a coemptio com um "amigo", o qual a transferia, por intermédio da mancipatio, a um terceiro que, por usa vez, a devolvia. Em conseqüência, o coemptionator tornava-se o tutor da mulher (tutor fiduciarius). Já o testamento per aes et libram, que é a forma clássica de testamento, tem origem na mancipatio fiduciae causa. Por ele, o sujeito que não pudesse ou não quisesse se servir das formas antigas de testamento, cuja validade contava com a intervenção de todo o populus, realizava a mancipatio de seu patrimônio a uma pessoa de sua confiança. Com a morte do alienante, o adquirente deveria distribuir o patrimônio às pessoas e nos modos indicados pelas instruções que lhe foram entregues - cf. B. BIONDI, Istituizioni cit. (nt. 69 supra), pp. 366-368.

P. F. GIRARD também indica usos menos conhecidos da fidúcia. Seriam eles: (i) a doação, em caso de morte, transferindo a propriedade a uma pessoa que se obriga a retransferi-la a outra ou seus descendentes sobreviventes; (ii) a restituição de dote; (iii) a doação a pessoa interposta, transferindo a propriedade a outra que se obriga a transferir novamente a um terceiro; (iv) a transferência da propriedade sobre um escravo a um terceiro, que se obriga a libertá-lo; (v) e, por fim, a transmissão da guarda de um filho a outro paterfamilias, para que este o emancipasse em seguida (fiducia remancipationis causa) - cf. Manuel élémentaire cit. (nt. 26 supra), p. 552.

No mesmo sentido, R. JACQUELIN, afirma ser bastante vasto o domínio de aplicação da fidúcia, pois esta abrangia todas as necessidades de prestação de garantia, dentro do contexto da boa-fé. A fidúcia romana correspondia, portanto, a "une convention basée sur la bonne foi, ayant pour cause un acte juridique solennel translatif d'un droit de propriété ou d'um droit de puissance, et pour object um autre act juridique inverse tendant à asséantir lês effect du premier" (= "uma convenção baseada na boa-fé, havida em razão de um ato jurídico solene translativo de um direito de propriedade ou de um direito de posse, e tendo por objeto um outro ato jurídico inverso tendente a reverter os efeitos do primeiro") - cf. De la fiducie, $1^{\mathrm{a}}$ ed., Paris, A. Giard, 1891, p. 23.

${ }^{83}$ Nos referimos aqui especificamente a Quellenforschungen in den Edictcommentaren, in SZ 3 (1882), pp. 104 e ss.

A linha de estudo do autor - que ainda hoje continua a despertar a atenção dos romanistas, se concentra em duas principais obras: Das Edictum perpetuum cit. (nt. 50 supra); Palingenesia iuris civilis (iuris consultorum reliquae quae Iustiniani Digesta continentur ceteraque iurisprudentiae civilis fragmenta minora secundum auctores et libros disposuit) I e II (1889), reimpr., Aalen, Scientia, 2000. F. SCHULz traz interessante passagem sobre as anteriores tentativas de outros estudiosos - cf. History of roman legal science, London, Oxford University, 1946, p. 340.

${ }^{84}$ Cf., e.g., Gai. 9-10. 
levou o autor à descoberta de que o segundo grupo de textos fosse originariamente dedicado à fidúcia ${ }^{85}$. Assim, os compiladores apenas teriam reconduzido ambos os grupos sob a rubrica dedicada ao penhor ${ }^{86}$, instituto bastante análogo, ao menos em sua função prática ${ }^{87}$.

A partir da descoberta de O. LENEL incrementou-se a produção crítica sobre a fidúcia clássica, com a publicação de diversos trabalhos notáveis sobre o tema ${ }^{88}$. Com o impulso proporcionado por seus estudos, diversas foram as teorias que surgiram sobre os efeitos da fiducia cum creditore e, consequentemente, também na lex commissoria.

A algumas dessas fontes correspondentes aos livros dos mencionados juristas clássicos, porém, nos ocuparemos mais adiante, especialmente em relação a dois fragmentos originariamente dedicados à compra e venda ${ }^{89}$.

Isso porque, ainda que indiretamente, a descoberta de O. LENEL também foi capaz de reacender as controvérsias relativas algumas fontes não

${ }^{85} \mathrm{O}$ edito pretoriano deveria regular o penhor ao lado do comodato, sob a rubrica de rebus creditis, e a fiducia ao lado do depósito, tratando de bonae fidei iudiciis - cf. O. LENEL, Das Edictum Perpetuum cit. (nt. 50 supra), pp. 254 ss e 288 ss.

${ }^{86}$ Cf. O. Lenel, Das Edictum Perpetuum cit. (nt. 50 supra), p. 254. Para C. Longo, O. LENEL teve razão em concluir que o grupo de textos modificado pelo legislador foi o segundo, ou seja, aquele em que os compiladores trataram do penhor por uma segunda vez, junto ao depósito. Isso porque o edito pretoriano devia regular o penhor ao lado do comodato, sob a rubrica de rebus creditis, e a fidúcia ao lado do depósito, tratando de bonae fidei iudiciis - cf. Corso di diritto romano cit. (nt. 46 supra), pp. 32-33.

87 Cf. C. LONGO, Corso di diritto romano cit. (nt. 46 supra), p. 32. Todavia, como sublinhou M. KASER, do momento que os juristas clássicos eram conscientes da identidade de função desenvolvida pela fiducia cum creditore e do penhor, se pode entender que muitos fragmentos indicassem originariamente a disciplina válida para ambas as formas de garantia real e então também as fontes expressamente dedicadas ao penhor possam ser utilizadas para uma melhor compreensão da fidúcia, tendo sempre em consideração, porém, a necessidade de individuar aqueles aspectos de regime incompatíveis com a estrutura do negócio fiduciário - cf. Studien zum römische Pfandrecht, in TR 44 (1976), pp. 236-238.

${ }^{88}$ Cf., especialmente, A. AsCOLI, Le origini cit. (nt. 46 supra); C. LONGO, Corso di diritto romano cit. (nt. 46 supra); P. LAMBRINI, Lineamenti cit. (nt. 45 supra); P. FREZZA, Corso di diritto romano cit. (nt. 46 supra); P. FUENTESECA, Líneas generales cit. (nt. 46 supra); A. BURDESE, “Lex commissoria” cit. (nt. 46 supra); N. BEllocCI, La tutela della fiducia cit. (nt. 46 supra); P. Collinet, Deux textes retrovés sour la fiducia, "Studi Besta, I, Milano", 1939; A. DALMARTEllo, "Fiducia cum creditore" e prescrizione, in Il Contrato - Sologe in onore di Giorgio Oppo, v. 1, Padova, CEDAM, 1992; R. JACQUElin, De la fiducie cit. (nt. 82 supra); P. OERTMANN, Die Fiducia cit. (nt. 50 supra); S. SANTANGELO, Fiducia cum creditore: mandato irrevocabile a sopo di garanzia, in Fiducia, Trust, Mandato ed Agency, Milano, Giuffrè, 1972; A. WATson, The Origins cit. (nt. 46 supra).

${ }^{89}$ Cf. item II.2.3. 
jurídicas, além da já citada fórmula bética. Uma dessas é o conjunto de fragmentos trazido em P.S. 2, 13, sob a rubrica "de lege commissoria".

Em que pese o esforço de uma doutrina mais antiga ${ }^{90}$ ao tentar identificar traços da lex commissoria em tais textos, que apresentam uma tratação bastante sintética da fiducia cum creditore, nada se encontra de conclusivo sobre a estrutura do instituto da leitura desses parágrafos ${ }^{91}$ :

Pauli Sententiarum 2, 13, 6-9:

6. Si creditor rem fiduciae datam uni ex 6 . Se o credor legasse a um de seus heredibus vel extraneo legaverit, adversus herdeiros ou a um terceiro a coisa dada omnes heredes actio fiduciae competit. 7. Si em fiducia, a ação de fiducia <contrária> creditor rem fiduciariam fecerit meliorem, compete contra todos seus herdeiros. 7. Se ob ea recuperanda quae impendit iudicio o credor melhorasse <com uma fiduciae debitorem habebit benfeitoria> a coisa dada em fiducia, obnoxium. 8. Novissimus creditor priorem estará sujeito o devedor à ação de fidúcia oblata pecunia, quo possessio in eum para <o credor> recuperar <aquilo> que transferatur, dimittere potest. Sed et prior gastou. 8. O último credor pode liberar o creditor secundum creditorem, si voluerit, anterior, oferecendo o valor do seu crédito dimittere non prohibetur, quamquam ipse in para que a posse seja transferida a ele. pignore potior sit. 9. Servus si mutuam Mas não é proibido se quiser o credor pecuniam tempore servitutis acceperit, ex ea anterior liberar o posterior ainda que o obligatione post manumissionem conveniri mesmo seja posterior na garantia 9. Se um non potest. escravo recebesse dinheiro mutuado em tempo da escravidão, não pode ser demandado por essa obrigação depois da manumissão.

As sentenças merecem atenção por apresentarem a única menção à cláusula comissória fiduciária fora do Corpus Iuris Civilis. O fato de sequer

${ }^{90}$ Cf., e.g., A. SACCHI. Sul patto commissorio in diritto romano, in Archivio Giuridico, v. 55, Pisa, Archivio Giuridico, 1895, pp. 189 e ss.

91 Neste item, visando uma maior aproximação ao teor original do texto, foi utilizada a versão mais antiga da obra atribuída a Paulo (i.e, "Sententiae Receptae Paulo Tibutae”) - cf. G. F. HAENEL, Lex romana visigothorum, Lipsiae, Sumptibus et typis B. G. Teubneri, 1848, p. 362. 
mencionarem a estrutura da cláusula, contudo, tem sido alvo de questionamento daqueles que se propuseram a estudar o tema ${ }^{92}$.

Dentre esses, a tese de B. NoORDRAVEN ${ }^{93}$ tem se destacado. Segundo o autor, a rubrica "de lege commissoria" teria sido erroneamente empregada, sendo mais provável que pertencesse ao posterior título P.S. 2, 17, que cuida da venda. Isso demonstraria, inclusive, coerência com o tratamento dado ao instituto no título 18 do Digesto. Tal hipótese, contudo, carece de indícios nas fontes e não consegue explicar o uso primitivo do verbete fiducia - posteriormente substituído pelo penhor $^{94}$ - em diversas passagens do texto.

Parece mais plausível acreditar que, não obstante a escassez de seu conteúdo não nos permita maiores esclarecimentos, os textos de Paulo podem ser considerados um indício, ainda que bastante tênue, de uma possível conexão, subsistente em época mais avançada, entre a lex commissoria e o negócio fiduciário a escopo pignoratício ${ }^{95}$.

Igualmente carente de apoio nas fontes é a tese de O. GRADENWITZ ${ }^{96}$, que tenta uma aproximação entre a lex commissoria em matéria de venda e a lex commissoria fiduciária, a partir da expressão "emit ob sestertios" presente no início da chamada mancipatio pompeiana ${ }^{97}$ :

\begin{tabular}{l|l|l} 
"Poppaea Prisci liberta Note iuravit pueros & Poppaea Note, liberta de Prisco, jurou que \\
Simplicem | et Petrinum, sive ea mancipia & os escravos Simplex e Petrino, ou com \\
alis nominib $[u s] \mid$ sunt, sua esse seque & nomes diversos são seus escravos, \\
possidere, neque ea mancipia [...] | ali & pertencem a ela, e que esses não forem \\
ulli obligata esse neque sibi cum $u l<l>o$ & reclamados por qualquer outra pessoa e
\end{tabular}

${ }^{92}$ Cf., especialmente, B. Noordraven, Pomp., D. 13, 7, 6 pr. - Un caso di "pignus", in BIDR 56 (1980), p. 248.

${ }^{93}$ Cf. B. NOORDRAVEn, Pomp., D. 13, 7, 6 pr. cit. (nt. 92 supra), p. 248.

${ }^{94}$ Cf. G. F. HAENEL, Lex romana visigothorum cit. (nt. 91 supra), p. 362.

${ }^{95}$ Nesse sentido, F. SCHULZ, para o qual o título constitui um precioso indício de que, mesmo em períodos mais avançado, ainda subsistia uma estreita conexão entre o pacto comissório e o negócio fiduciário - cf. Das Ediktssystem in den Paulus-Sentenzen, in SZ 47 (1927), pp. 39 e 47. No mesmo sentido, A. BURDESE, "Lex commissoria" cit. (nt. 26 supra), p. 11.

${ }^{96}$ Conjecturen, IV - Emptio ob nummos umd lex commissoria, in LABEO 33 (1897), pp. 209-212.

${ }^{97}$ Para uma análise crítica da fonte à luz da fiducia - cf., especialmente, R. JACQUELIN, De la fiducie cit. (nt. 82 supra), pp. 13-14. 


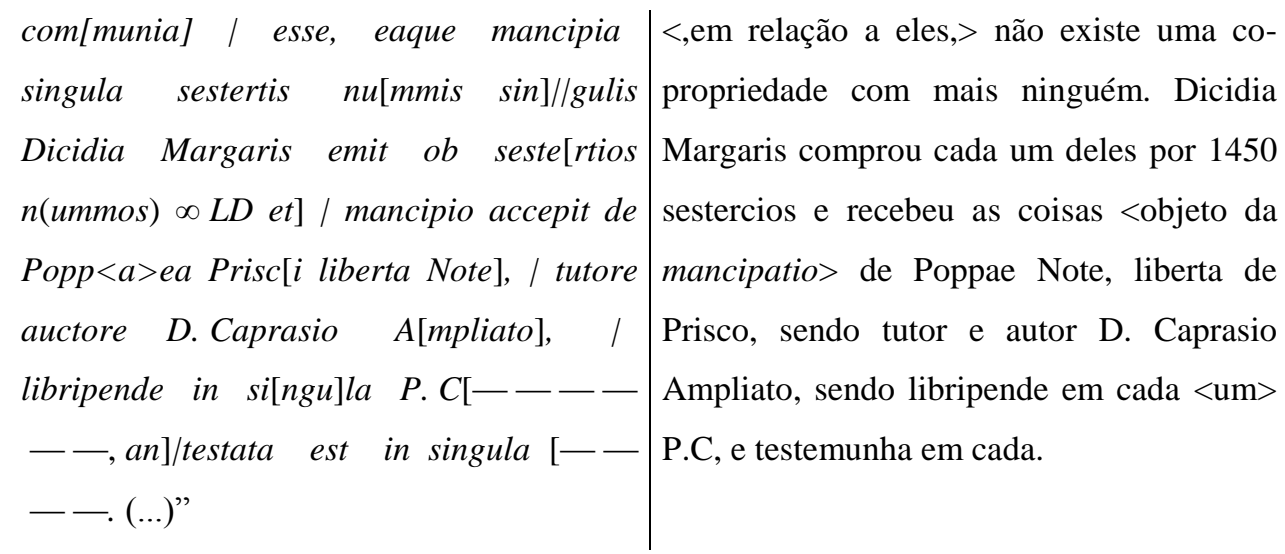

Em breve reflexão sobre o tema, o autor ${ }^{98}$ estabelece como centro de tal possível paralelo o fato de ambos os casos terem em comum o direito à restituição da propriedade condicionado ao pagamento do preço por parte do comprador, na compra e venda, e ao pagamento do débito por parte do devedor fiduciante ${ }^{99}$.

A hipótese foi, desde logo, afastada por parte da doutrina ${ }^{100}$. Isso porque, especialmente no que diz respeito à fiducia, a obrigação de restituição subsiste, independentemente da existência ou não da lex commissoria ${ }^{101}$.

Ainda nesse diapasão, para alguns estudiosos ${ }^{102}$, ao menos nos tempos mais antigos, o credor fiduciário poderia conservar a coisa, mas não com ela satisfazer-se. Tratar-se-ia, portanto, de uma mera forma de pressão psicológica sobre o devedor ${ }^{103}$, e não de um meio de satisfação.

Em origem, então, o credor fiduciário não teria sido liberado da sua obrigação de restituição e a lex commissoria teria sido introduzida justamente para

\footnotetext{
${ }^{98}$ Das Ediktssystem cit. (nt. 95 supra), pp. 351-353.

${ }^{99}$ No mesmo sentido, B. BIONDI, "Iudicia bonae fidei”, in Annali del Seminario giuridico della Università di Palermo, 7 (1920), p. 166.

${ }^{100}$ Cf., especialmente, A. MANiGK, Fiducia, in RE 6 (1909), p. 2299. Mais recentemente, A. BURDESE, “Lex commissoria” cit. (nt. 26 supra), p. 11.

${ }^{101} \mathrm{Na}$ verdade, o fato de a restitutio não aparecer mencionada na Tabula Baetica, por exemplo, pode significar que tal menção não seria necessária, por encontrar-se implícita na própria mancipatio fiduciária e no pactum conventum, que determina a duração do vínculo fiduciário de garantia até o pagamento do crédito pelo devedor fiduciante - cf. P. FUENTESECA, Líneas generales cit. (nt. 46 supra), p. 407.

102 Cf. e.g., G. Segrè, Corso cit. (nt. 72 supra), p. 48 e ss.; A. BuRdeSE, "Lex commissoria" cit. (nt. 26 supra), p. 9.

${ }^{103}$ Cf. P. LAMBRINI, Lineamenti cit. (nt. 46 supra), p. 267.
} 
isentá-lo, em presença de determinadas circunstâncias, de tal responsabilidade ${ }^{104}$. Assim, o desenvolvimento histórico teria sido no sentido de acrescer e não de diminuir a faculdade do fiduciário.

Houve ainda quem sustentasse ${ }^{105}$, a partir de tal linha de pensamento, que a fiducia cum creditore originária seria, na verdade, uma transposição ao sistema romano da $\pi \rho \tilde{\alpha} \sigma ı \varsigma$ غ̇ंì $\lambda \hat{\sigma} \sigma \varepsilon$, venda com pacto de resgate cujo preço seria constituído pelo montante do crédito garantido.

Tal tese, contudo, foi logo afastada pela doutrina ${ }^{106}$, que em parte se apoiou na ideia de uma fiducia cum creditore como negócio abstrato, a partir do qual o credor se tornava definitivamente proprietário do bem já no momento da mancipatio ou da in iure cessio fiduciária.

Nesse sentido, evidentemente, não seria necessária a previsão de pactos específicos, como a lex commissoria, uma vez que, faltante o adimplemento, o credor poderia liberamente ter a coisa ou vendê-la sem incorrer em qualquer tipo de penalidade. Afinal, tais faculdades eram já inerentes ao seu ilimitado direito de proprietário ${ }^{107}$.

Grande crítico de tal entendimento, C. LONGO $^{108}$ vai além. Para o autor, a existência de uma similar construção, ainda que implícita, na fiducia cum creditore pressuporia, desde logo, que o credor permanecesse definitivamente desvinculado da obrigação de restituir a coisa, pela faculdade de tê-la "pure et simpliciter" - situação que apenas se agravaria na hipótese de um eventual excedente do valor do bem em relação ao débito ${ }^{109}$. Além disso, completa ${ }^{110}$, a

${ }^{104}$ E era necessário a menção dos herdeiros para que eles também lhe pudessem aproveitar - cf. A. BURDESE, La menzione degli eredi nella fiducia cum creditore, in Studi Solazzi, Napoli, 1948 , p. 324.

${ }^{105}$ Cf., entre outros, V. ARANGIO-RUIZ, La compravendita in diritto romano, $2^{\mathrm{a}}$ ed., v. 1 , Napoli, Eugenio Jovene, 1954, p. 308; P. FrEZZA, Corso di diritto romano cit. (nt. 46 supra), p. 4.

${ }^{106}$ Cf. W. ERBE, Die Fiducia cit. (nt. 26 supra), p. 44;. C. LONGO, Corso di diritto romano cit. (nt. 46 supra), p. 84.

${ }^{107}$ Contra - cf. O.GRADENWITZ, Conjecturen cit. (nt. 96 supra), pp. 210-211.

${ }^{108}$ Fiducia cum creditore cit. (nt. 57 supra), p. 818.

109 A solução é que o credor pudesse conservar a coisa por sua decisão unilateral, e sem violar a boa-fé, porque correspondesse ao devedor o superfluum - cf. C. LONGO, Fiducia cum creditore cit. (nt. 57 supra), p. 819.

${ }^{110}$ C. LongO, Fiducia cum creditore cit. (nt. 57 supra), p. 818. 
jurisprudência clássica dificilmente teria admitido tal situação, que claramente violaria o critério de boa-fé ${ }^{111}$, fundamental à estrutura do negócio.

W. ERBE ${ }^{112}$, posteriormente apoiado por M. KASER ${ }^{113}$, chegou, inclusive, a sustentar ao instituto uma primitiva situação de "reine Sachhaftung", em que o bem podia ser resgatado mediante o pagamento o débito, que verdadeiro e próprio débito ainda não era: tratava-se, então, de um "Ersatzpfand" e não ainda de um "Sicherungspfand" 114.

Isso significaria que o credor, obtida a garantia fiduciária, seria privado da ação de crédito e apenas poderia, se insatisfeito ao término do prazo, ter a coisa em pagamento (suportando naturalmente os riscos consistentes em uma eventual depreciação ou perecimento da mesma), no que A. BURDESE ${ }^{115}$ denomina "tesi della primitiva pura rispondenza reale".

Segundo o autor ${ }^{116}$, a teoria merece ser criticada pois:

a) não leva em conta as características peculiares com que em Roma se apresenta a "fiducia cum creditore”, que seria uma aplicação não originária de um instituto correspondente a diversos fins (dentre os quais talvez o pignoratício seja o mais afastado da função natural da alienação 'fiduciae causa');

b) renuncia a uma visão unitária da fiducia cum amico e da fiducia cum creditore, baseada na obrigação à restituição, visto como efeito esseincial do negócio, para entender, diferentemente, que a fidúcia fosse em origem, quanto à sua aplicação pignoratícia, um "Verfallpfand" $" 117$. Ou seja, que se apresentasse essencialmente em função de datio in solutum, com um anexo e secundário pacto de resgate;

${ }^{111}$ Cf. nt. 51 supra.

${ }^{112}$ Die Fiducia cit. (nt. 26 supra), p. 36.

${ }^{113}$ Recensão a W. ERBE, Die Fiduzia, in SZ 61 (1941), p. 467.

114 Cf. W. KUnKEL, Hypothesen zur Geschichte des römischen Pfandrechts, in SZ 90 (1973), pp. 150 e ss.

115 “Lex commissoria” cit. (nt. 26 supra), pp. 22-23.

116 “Lex commissoria” cit. (nt. 26 supra), p. 23.

${ }^{117}$ Cf., especialmente, M. KASER, que entende que na época mais antiga vigesse um regime de "Verfallpfand", mas que, em idade mais avançada, fosse necessária a inserção de uma lex commissoria para que fossem obtidos os mesmos efeitos - Cf. Recensão a A. Burdese, "Lex commissoria” e "ius vendendi", in SZ 67 (1950), p. 557; Das römische Privatrecht, v. 1, $2^{\mathrm{a}}$ ed., München, Beck, 1971, p. 480. 
c) é significativo que a "reine Sachhaftung" deva ser afastada pelo teor de D. 13, 7, 6 pr. ${ }^{118}$, cuja afirmação inicial, resgatando as ideias de Sabino, constitui o mais antigo testemunho em matéria;

E. RABEL ${ }^{119}$ acrescenta ainda um quarto argumento contrário à teoria:

d) A aplicação "vendere licere" negaria a teoria dos autores de que haveria uma exata correspondência entre a coisa e o crédito, uma vez que ao devedor é reservado o direito ao superfluum após a venda da coisa dada em $\operatorname{garantia}^{120}$.

De qualquer modo, pelo teor das fontes até agora apresentadas, ainda que pareça bastante verossímel a corrente defendida por C. $\mathrm{LONGO}^{121}$, certo é que não podemos concluir, com segurança, por uma irrefutável existência da lex commissoria na fiducia cum creditore. Em outras palavras, ainda que se possa afirmar que não existam motivos concretos para negar sua presença na fiducia ${ }^{122}$, não há, nas fontes, provas positivas de nenhum gênero que nos permita concluir contrariamente.

Tais incertezas levaram, inclusive, a algumas ideias absurdas. Há quem ${ }^{123}$ desconsidere, e.g, uma eventual coexistência dos institutos, acreditando, contra o teor de documentos negociais ${ }^{124}$, que a fiducia originária se transformasse no pacto comissório, porque não poderia mais responder às crescentes exigências comerciais.

Feitas essas considerações, resta, contudo, a análise de dois fragmentos relativos à compra e venda, que também merecem atenção para a

${ }^{118}$ Sobre o fragmento - cf. item II.2.5 do trabalho.

119 Grundzüge des römischen Privatrechts, in Holtzendorff-Kohler Enzyklopädie der Rechtswissenschaft, Leipzig und Berlin, Auflage, p. 491.

${ }^{120}$ Contra, sem, contudo, justificar o porquê, A. BURDESE, "Lex commissoria” cit. (nt. 26 supra), p. 23.

${ }_{121}$ Cf. nota 108 supra.

${ }^{122}$ Cf. C. Longo, Corso di diritto romano cit. (nt. 46 supra), p. 71.

${ }^{123}$ Cf., e.g., A. SACCHI. Sul patto commissorio cit. (nt. 90 supra), p. 189.

${ }^{124} \mathrm{Na}$ verdade, alguns são os documentos fragmentários trazidos pela prática que atestam a difusão do instituto da fiducia cum creditore ainda no curso do século I - Cf. M. ZINGALE, In tema di 'fiducia cum creditore' - I documenti della prassi, in Labeo 46 (2000), p. 451. 
resolução de nosso problema. São eles: Pomp. 35 ad Sab. D. 18, 3, 2 e Ulp. 30 ad ed. D. 18, 3, 3, a serem oportunamente estudados ${ }^{125}$.

\subsubsection{No PENHOR: A CONTROVERSA PRESENÇA DA LEX}

\section{COMMISSORIA PIGNORIBUS NOS FORMULÁRIOS CATONIANOS}

Dentre os inumeráveis problemas relativos às garantias reais, ainda permanece sem solução pacífica entre os romanistas aquele concernente à delimitação do exato período em que o penhor tenha efetivamente sido reconhecido pelo ordenamento jurídico romano.

É possível afirmar com algum maior grau de certeza, contudo, que o instituto pignoratício apenas tenha tido tutela jurídica pouco antes do início do século II a.C., durante o processo interdital ${ }^{126}$.

De qualquer modo, ainda que incerta sua exata origem, alguns autores $^{127}$ concedem já ao primitivo penhor romano natureza comissória. Em outras palavras, acreditam ser possível, mesmo nos tempos primórdios de evolução do instituto, a atribuição imediata da propriedade ao credor que não teve seu crédito satisfeito ao término do prazo estabelecido na obrigação garantida.

Para tanto, a fim de justificarem suas teorias, procuram encontrar uma base de apoio nos formulários ${ }^{128}$ catonianos "De agri cultura"129, especialmente

${ }^{125}$ Cf. item II.2.3.

${ }^{126}$ Cf. A. BURDESE, “Lex commissoria” cit. (nt. 26 supra), p. 95.

No entanto, que a ação real de penhor não representasse uma adequada garantia para o credor se tira, outrossim, do fato de que, a partir do II século d.C., os atos de disposição da coisa penhorada foram sancionados também criminalmente, dentro da fatispécie do estelionato - cf. L. GAROFALO, La persecuzione dello stellionato in diritto romano, Padova, CEDAM, 1998, p. 73.

127 Cf. M. KASER, Das römische Privatrechts cit. (nt. 119 supra), p. 388; A. BURDESE, "Lex commissoria" cit. (nt. 26 supra), p. 23.

${ }^{128}$ O termo "formulário" não seria adequado porque se trata, em verdade, de sugestões e indicações, não de simples esquemas contratuais, a serem pura e simplesmente preenchidos com os nomes das partes - cf. E. I. BEKKER, Ueber die 'leges locationis' bei Cato 'de re rustica', in SZ 3 (1864), p. 416. Optamos, contudo, por obter uma terminologia bastante arraigada na doutrina e que facilita a indentificação da obra ao leitor - cf. nt. 129 infra.

${ }^{129}$ Dentre as obras que tratam do assunto, A. ARCANGELI, I contratti agreri nel 'De agri cultura' di Catone, in Studi Pier Paolo Zanzucchi, Milano, 1927, 65 ss; E. I. BEKKER, Ueber die 
nos capítulos 146-150. Ali são apresentados esquemas de contratos agrários, provavelmente já bastante difusos em período anterior ao do próprio Catão, cujo importante trabalho de recolha e reelaboração técnica, no entanto, não deve ser de qualquer modo desmerecido $^{130}$.

Em que pesem as muito prováveis alterações ${ }^{131}$ sofridas ao longo dos tempos, o texto ainda é de grande valia para melhor iluminar os séculos II e III a. $C^{132}$, período histórico longínquo, em relação ao qual, infelizmente, são poucos os indícios que chegaram até nossos dias ${ }^{133}$.

Ainda que a análise dos formulários constitua um ponto de referência de grande - ou melhor, de essencial - importância para o estudo das origens do instituto do penhor, a diversidade de resultados dela derivada parece estar longe de poder ser considerada pacífica.

De fato, apesar de as ideias trazidas pelo escritor serem apresentadas em linguagem bastante clara, a interpretação técnica das cláusulas presentes na obra é ainda hoje bastante controversa e se polariza em duas diferentes e principais teorias.

\footnotetext{
'leges locationis' cit. (nt. 94 supra) pp. 416 ss.; A. MAZZARINO, Introduzione al "De agi cultura" di Catone, Roma, Atlante, 1952, pp. 1 e ss; E. AlBerTARIO, Contratti agrari nel 'de agri cultura' di Catone, in Rivista di diritto agrario 15 (1936), pp. 2 e ss; M. SARGENTI, Il 'de agri cultura' di Catone e le origini dell'ipoteca romana, in SHDI 22 (1956), pp. 158 e ss; P. FREZZA, I formulari catoniani e le forme della protezione del creditore pignoratizio, in Studi in onore di Emilio Betti, v. 2, Milano, 1962, pp. 435 e ss; A. BURDESE, Catone e la vendita di vino, in SDHI 46 (2000), pp. 269 e ss.

${ }^{130}$ Cf. P. FREZZA, I formulari catoniani cit. (nt. 129 supra), p. 435. Contra, M. SARGENTI, segundo o qual essa parte da obra (146-150) sequer passou pelas mãos de Catão, sendo obra de um trabalho de compilação pouco mais tardio. $\mathrm{O}$ autor admite, no entanto, que a diferença temporal entre tal compilação e o trabalho de Catão é pequena e não se estende para além dos limites do Sec. II a.C., insuficiente, portanto, para descaracterizar o conteúdo dos fragmentos em questão - Il 'de agri cultura' di Catone, (nt. 129 supra), pp. 160-161.

${ }^{131}$ Sobre eventuais alterações ao pensamento de Catão e sua importante influência na obra de Cícero - cf., especialmente, G. CALBoli, Cicerone, Catone e i neoatticisti, in Ciceroniana, Leiden, E. J. Brill, 1975, pp. 51-62 e 83-97.

${ }^{132}$ Segundo P. FREZZA, mais especificamente, o sec. III a.C. - cf., I formulari catoniani cit. (nt. 129 supra), p. 435.

${ }_{133}$ A tal propósito são de fato de serem reconduzidas as cláusulas negociais reportadas por Catão - cf. A. BURDESE, Pegno (diritto romano), in ED 32 (1982), p. 664.
} 
Um grupo de autores mais antigos, como já mencionamos ${ }^{134}$, defende, pela leitura do mencionado grupo de textos (146-150), a existência de uma verdadeira e própria conventio pignoris, já no século III a.C.

Antes de prosseguirmos, no entanto, cabe aqui uma breve observação.

Como lembra G. LA PIRA ${ }^{135}$, representante de uma teoria que ganhou força nas últimas décadas, a construção do pignus como "contratto reale, fonte di diritto reale, tutelato con azione reale ${ }^{\# 136}$ não pode ser considerada clássica.

Antes da configuração mais tardia do instituto, com as características acima mencionadas pelo autor ${ }^{137}$, deve-se considerar um período anterior, no qual se verificava um negócio translativo da possessio $^{138}$, em tudo análogo à traditio $^{139}$, a favor do credor pignoratício. Era a chamada conventio pignoris.

Embora não se possa apontar diferenças suficientes para alterar a fundamental identidade de estrutua dos dois institutos ${ }^{140}$ (sendo ambos construídos como negócios translativos da posse e regulados por idênticos princípios fundamentais), há uma peculiaridada em relação à conventio pignoris que não poderia ser desconsiderada: diferentemente do que ocorre no pignus, nela, a transferência efetiva da posse é postergada ao momento do inadimplemento ${ }^{141}$.

Em um contato mais superficial com o tema, tratar de conventio pignoris em um capítulo dedicado ao penhor pode causar estranhamento,

\footnotetext{
${ }^{134}$ Cf. A. MANIGK, "Hypotheca", in RE 17 (1914), p. 353; "Pignus", in RE 39 (1941), pp. 1239 e ss.

${ }^{135}$ La struttura classica della "conventio pignoris", in Studi in memoria di Umberto Ratti, Milano, p. 228.
}

${ }^{136}$ Cf. G. LA PIRA, La struttura classica cit. (nt. 135 supra), p. 228.

${ }^{137}$ E que estariam presentes, e.g., como se vê em Inst. 3, 14, 4; 4, 6,7; Gai. 2 aur., D. 44, 7, 1, 6; Ulp. 15 ad ed., D. 20, 1, 17.

${ }^{138}$ Sobre a terminologia da posse nas fontes jurídicas e literárias - cf., especialmente, E. ALBERTARIO, La terminologia del possesso nella compilazione giustinianea e nelle fonti bizantine, in BIDR 27 (1914), pp. 275 e ss.; Vecchi e nuovi problemi intorno alla terminologia del possesso, in Studii Chironi I, Torino, pp. 377 e ss.

Ainda, sobre a questão do penhor irregular no direito romano e seu ulterior desenvolvimento histórico - cf. T. CLAPS, Del cosidetto pegno irregolare, Bologna, Fava e Garagnani, 1896, pp. 5-67.

${ }^{139}$ Cf. G. LA PIRA, La struttura classica cit. (nt. 135 supra), p. 228.

${ }^{140}$ Cf. G. LA PIRA, La struttura classica cit. (nt. 135 supra), p. 228.

${ }^{141} \mathrm{Na}$ verdade, em período mais anterior de seu desenvolvimento, o que modernamente se entende por penhor, na atividade prática, poderia perfeitamente se confundir com a hipoteca, sendo a diferenciação mais rígida entre os dois institutos posterior - cf. G. LA PIRA, La struttura classica cit. (nt. 135 supra), p. 228. 
sobretudo pelo fato de que os manuais ${ }^{142}$ sempre relacionam-a à figura da hipoteca. Ocorre, contudo, que, diferentemente do que se verifica em período hodierno, no Direito Romano, o emprego de uma ou de outra figura dependia apenas da vontade das partes e não da natureza do objeto dado em garantia ${ }^{143}$.

As dificuldades para delinear, nas fontes, uma e outra figura, levam a doutrina $^{144}$ - mais corretamente, como esperamos poder demonstrar - a desvincular-se de construções dogmáticas modernas e analisar os textos catonianos à luz da figura de um penhor primitivo ${ }^{145}$. É esta a tendência que ora seguimos.

Em oposição a esse primeiro conjunto de autores que vêem no texto as origens da conventio pignoris, mais recentemente ${ }^{146}$, tem-se verificado a tendência de interpretar os formulários catonianos como referentes a uma responsabilidade extracontratual nascida ex stipulatu.

Feitas essas considerações iniciais, passemos, então, à leitura de Cat., De Agri. 146, que, dentre o citado grupo de textos dos formulários, é aquele que maior relevância apresenta para os fins de nossa pesquisa:

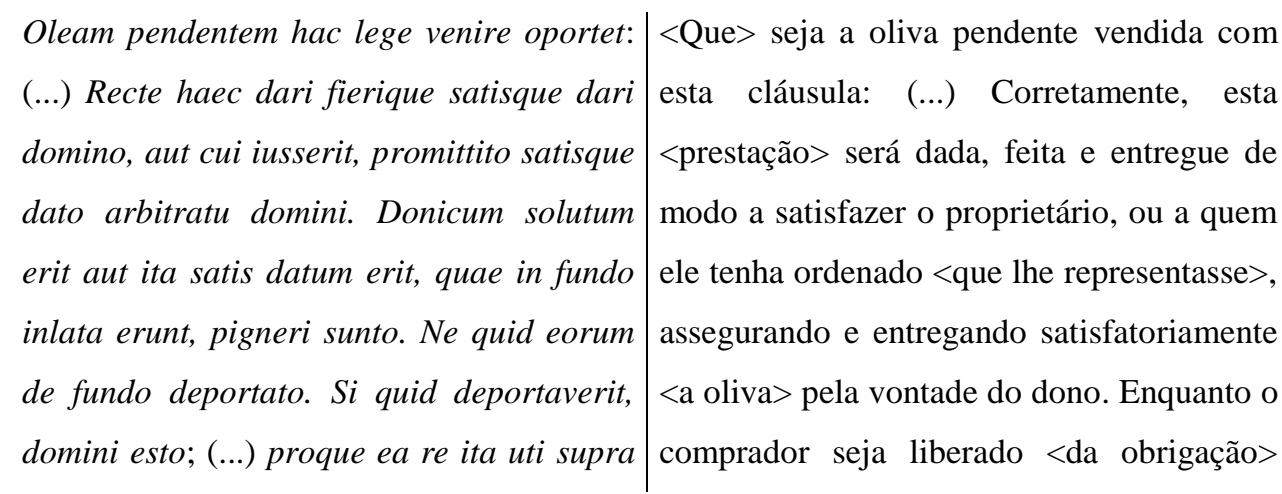

${ }^{142}$ Cf., apenas a título exemplificativo., G. PUGLIESE, Istituzioni di diritto romano, $2^{\mathrm{a}}$ ed., Torino, G. Giappichelli, pp. 498 e ss.

${ }_{143}$ Cf., especialmente, M. TALAMANCA, Istituzioni cit. (nt. 71 supra), p. 480.

${ }^{144}$ Cf. N. Herzen, Origine de l'hypothèque cit. (nt. 26 supra), p. 157; Ascoli, Le origini dell'ipoteca cit. (nt. 46 supra), p. 55; H. KRELLER, Pfandrechtliche Interdikte und Formula Serviana, in SZ 64 (1944), pp. 307 e 335.

${ }^{145}$ M. SARGENTI faz uma especial crítica à generalidade dos autores que se debruçaram sobre o tema. Segundo o autor, incorrem, em sua maioria, em "gravi equivoci" ao atribuir ao penhor um valor unitário e imutável, desconsiderando, assim, a evolução histórica de sua construção dogmática - cf. Il 'de agri cultura' di Catone cit. (nt. 129 supra), pp. 159-160.

${ }^{146}$ Cf. M. SARGENTI, Il 'de agri cultura' di Catone cit. (nt. 129 supra), pp. 156 e ss. 
scriptum est item pignori sunto.

totalmente ou em grande parte, os utensílios
que sejam trazidos ao imóvel devam servir
de garantia e não poderão ser levados do
imóvel. Se <o comprador> os levar, serão
do proprietário; (...) e seus utensílios
servirão de garantia deste preço <da
obrigação principal>, como foi dito acima.

E. AlBERTARIO ${ }^{147}$, para reforçar sua tese de que é justinianéia - e não clássica - a idéia presente em um grupo de fragmentos ${ }^{148}$ em que se remete ao arbítrio de uma única parte contraente o adimplemento da obrigação ou a determinação da prestação ${ }^{149}$, recorre a tal formulário ${ }^{150}$.

$\mathrm{Na}$ verdade, segundo o autor ${ }^{151}$, a simples leitura do capítulo já permitiria presumir que a determinação da medida da prestação e da qualidade do objeto devido não é, no período de Catão, remetida ao arbítrio do proprietário, mas ao arbitrium boni viri de um terceiro detentor ${ }^{152}$.

Nesse sentido, o arbítrio exclusivo do proprietário não se verificaria no momento de determinar a qualidade do objeto vendido ou a medida da prestação. Isso porque, pelo teor do texto, as olivas deverão ser colhidas

${ }^{147}$ Contrati agrari cit. (nt. 129 supra), pp. 3-7.

${ }^{148}$ Cf., em especial, dois fragmentos relacionados à locação: Paul. 4 quaest., D. 17, 2, 77 e Paul. 34 ad ed., D. 19, 2, 24.

${ }^{149}$ No mesmo sentido, M. Rotond, L'azione di arricchimento, Milano, F. Vallardi, 1924, p. 221.

${ }^{150}$ Para o autor, também reforçariam a idéia a passagem em Cat., De Agr., 144, relativa à colheita das olivas ("oleam legendam hoc modo locare oportet: Oleam cogito recte omnem arbitratu domini, aut quem custodem fecerit, aut cui olea venierit (...) Scalae ita uti datae erunt, ita reddito, nisi quae vetustate fractae erunt. Si non erunt redditae, aequom viri boni arbitratu deducatur. Si quis redemptoris opera domino damni datum erit, resolvito: id viri boni arbitratu deducetur"), 145, relativo à obtenção do óleo ("oleam faciundam hac lege opertet locare: Facito recte arbitratu domini aut custodis, qui id negotium curabit (...) Siquid redemptoris opera domino damni datum erit, viri boni arbitratu deducetur") e 148, também relativo à venda das olivas sobre a árvore e do vinho nos tonéis ("vinum in doliis hoc modo venire opertet) In triduo proxumo viri boni arbitratu degustato, si non ita fecerit, vinum pro degustato erit. Quot dies per dominum mora fuerit, quo minus vinum degustet totidem dies emptori procedent”).

${ }^{151}$ Contrati agrari cit. (nt. 129 supra), p. 7

152 No mesmo sentido, J. H. MiCHEL, que, contudo, menciona genericamente a obra de Catão, sem fazer referência a qualquer capítulo específico - cf. L'influence de la "lex venditionis" sur les regles su contrat de vente, in RIDA 13 (1966), p. 339. 
"arbitratu domini", ou seja, segundo a vontade do dono. Neste momento, tanto a prestação quanto a contraprestação já teriam sido estabelecidas ${ }^{153}$.

Em outras palavras, pelo que se possa extrair do capítulo $146^{154}$, a vontade do proprietário far-se-ia relevante, e.g., apenas para determinar que a colheita começasse com determinada árvore, para estabelecer o pedaço de terra que mais lhe agrada ou, ainda, o modo para obtenção do óleo - caso em que a prestação já seria determinada e o comprador deveria estabelecer os limites previamente estabelecidos.

Complementarmente, para uma melhor compreensão do intento catoniano - em partes que, vale salientar, nos são mais importantes -, M. SARGENTI ${ }^{155}$ converte o formulário nas duas seguintes estipulações:

a) "Quae in fundo illata erunt, pignori esse, spondes?"

b) "Si quid eorum de fundo deportatum erit, mihi dari spondes?"

Esta dúplice estipulação criada pelo autor facilita significativamente a leitura do fragmento, ao individuar duas ideias de fundamental importância para sua compreensão. Delas temos que o negócio descrito por Catão tem por efeitos atribuir ao dominus o direito de garantia sobre os invecta et illata ${ }^{156}$ (a), e, no caso de inobservância da proibição de retirá-las do imóvel, transferir ao dominus a propriedade de tais coisas (b).

Se constituiria, então, a favor do proprietário do imóvel, o efeito da aquisição comissória das coisas retiradas do terreno, como conteúdo de uma segunda estipulação ad $_{h o c^{157}}$.

P. FREZZA ${ }^{158}$ critica M. SARGENTI por acreditar que o autor baseia sua construção na conversão do simples consensus em uma verborum obligatio, o que

${ }^{153}$ Cf. E. Albertario, Contrati agrari cit. (nt. 129 supra), p. 7.

${ }^{154} \mathrm{Cf}$., igualmente, naqueles mencionados na nt. 130.

${ }^{155}$ Il 'de agri cultura' di Catone cit. (nt. 129 supra), p. 156.

${ }^{156} \mathrm{O}$ uso de fazer obrigar as coisas colocadas pelo condutor sobre o fundo para a cultivação do mesmo era antigo e geral entre os romanos - cf. M. SARGENTI, Il 'de agri cultura' di Catone cit. (nt. 129 supra), p. 156.

${ }^{157}$ Cf. M. SARGENTI, Il 'de agri cultura' di Catone cit. (nt. 129 supra), p. 181.

${ }^{158}$ I formulari catoniani cit. (nt. 129 supra), p. 435 
seria incompatível com a pactuação catoniana "si quid deportaverit, domini esto" ${ }^{\prime 159}$.

Em outras palavras, esse capítulo dedicado à venda de um olea pendens $^{160}$, instigaria o intérprete à convicção de que a obrigação pecuniária do comprador deveria, então, fazer-se acompanhar de um ulterior empenho verbal assumido em modo solene. A leitura do texto, no entanto, daria a entender que a transferência seria imediata, sem necessidade de qualquer tipo de formalidade ${ }^{161}$.

Além disso, ainda que se considerem insuficientes a sua argumentação, o autor ${ }^{162}$ ainda manifesta sua discordância em relação à utilização da expressão "pignori esse”.

Isso porque, ao justificar sua construção, M. SARGENTI ${ }^{163}$ considera-a uma expressão técnica pela qual tanto a proibição de retirar os utensílios do terreno, quanto a transferência do direito de propriedade sobre tais utensílios, em caso de inobservância da regra, pudessem ser considerados efeitos naturais do ato mencionado por Catão.

P. FREZZA ${ }^{164}$ rebate tal argumento porque, para ele, não parece plausível que o "pigneri sunto", por si só, pudesse fazer nascer um direito de satisfação sobre as coisas ${ }^{165}$. Tampouco, adicionalmente, veria razão suficiente para que se pudesse pensar que, ao credor dos tempos de Catão, já viesse

${ }^{159}$ As dificuldades seriam, sobretudo, de ordem processual - cf. P. FREZZA, I formulari catoniani cit. (nt. 129 supra), p. 436.

${ }^{160}$ A cláusula reportada no texto era destinada a valer também na venda do vinum pendens e do vinum in doliis. Por outro lado, vale ressaltar que tanto o esquema pré-disposto para a venda do pabulum hibernum quanto aquele concernente à alienação dos fructus ovium contém previsões bastante similares: donicum solutum erit aut ita satis datum erit, quae in fundo inlata erunt, piguei sunto, ne quid eorum de fundo deportato, si quis deportaverit, domini esto (cap. 149.7-8); donec domino satisfecerit aut solverit, (pastor) pignori esto (cap. 150.7).

${ }^{161}$ Cf. P. FREZZA, I formulari catoniani cit. (nt. 129 supra), p. 436.

${ }^{162}$ Cf. P. FreZZA, I formulari catoniani cit. (nt. 129 supra), p. 436.

${ }^{163}$ Il 'de agri cultura' di Catone cit. (nt. 129 supra), pp. 182-183.

${ }^{164}$ I formulari catoniani cit. (nt. 129 supra), p. 437.

${ }^{165}$ Segundo P. FrEZZA, não seria concebível que, em qualquer período do desenvolvimento histórico do direito romano, o direito de propriedade pudesse surgir sobre uma coisa, mancipi ou nec mancipi, em virtude de um negócio obrigacional (e não de um negócio - formal ou não formal - translativo de direitos reais) - Cf. I formulari catoniani cit. (nt. 129 supra), p. 438. 
assegurado o exercício de similar direito de satisfação, como já se verifica nos tempos de Gaio com o interdictum Salvianum ${ }^{166}$.

Antes, a expressão "si quia deportaverit, domini esto" deveria ser entendida como um modo de reforçar, através da tutela processual de uma rei vindicatio, a precedente cláusula "quae in fundo inlata erunt, pigneri sunto"167.

O significado jurídico de "domini esto”, neste sentido, parece que mais verossimilmente deva ser o de conferir ao proprietário a faculdade de, unilateralmente, ter o domínio daquilo que lhe fora tirado. Ou seja, mais tecnicamente, teria o proprietário uma faculdade pactícia de pignoris capio $^{168}$.

As problemáticas interpretativas oferecidas pela obra catoniana, assim, são complexas, sobretudo porque, como parece ter ficado claro do que até agora se disse, há uma verdadeira escassez de fontes que a ela possam ser diretamente relacionadas. Isso permite que a doutrina fique livre para as mais diversas especulações, que, muitas vezes, não ultrapassam o plano das conjecturas, como fica claro da discussão travada entre P. FREZZA e M. SARGENTI.

$\mathrm{Na}$ verdade, é importante destacar que, no quadro do tipo descrito no capítulo 146, parece figurar a prestação, por parte do comprador, de uma stipulatio "omnicomprensiva" 169 em favor do proprietário das olivas, que segundo a opinião mais aceita na doutrina ${ }^{170}$ - teria se prestado não apenas à função de garantir o pagamento do preço da obrigação principal, mas também a garantir o adimplemento de outras obrigações assumidas pela parte adquirente ${ }^{171}$.

${ }^{166}$ Cf. Gai. 4, 147. Segundo, P. FrEZZA, é certo, porém, que um interdictum adipiscendae possessionis bastaria a tal fim - cf. I formulari catoniani cit. (nt. 129 supra), p. 436.

${ }^{167}$ Cf. P. FrEZZA, I formulari catoniani cit. (nt. 129 supra), p. 437

${ }^{168}$ Cf. P. FREZZA, I formulari catoniani cit. (nt. 129 supra), p. 437-438.

${ }^{169}$ Cf. M. TAlamanCA, La tipicità dei contratti romani fra "conventio" e "stipulatio" fino a Labeone, in Contractus e pactum (tipicità e libertà negoziale nell'esperienza tardorepublicana), Napoli, Edizioni Scientifiche Italiane, 1990, p. 61.

Entendimento diverso, todavia,destaca que apenas a partir do I sec. a.C., com testemunhos como o encontrado em Paul. 3 epit. Alf. dig., D. 17, 2, 71 pr., é que se possa verificar indícios de que na estipulação possa formalizar-se todo o conteúdo do contrato consensual - cf., especialmente, R. CARDILLI, L'obbligazione di "praestare" e la responsabilità contrattuale in diritto romano, Milano, Giuffrè, 1995, p. 66.

${ }^{170}$ Cf. M. TALAMANCA, La tipicità cit. (nt. 169 supra), p. 61.

171 Sobre a função da promessa prestada pelo adquiente, em forma de stipulatio, como "Sicherheitleistung" - cf. R. CARDILLI, L'obbligazione cit. (nt. 169 supra), p. 81. 
Tal elemento nos leva a entender que, não obstante à época fosse já conhecida a existência dos contratos consensuais, ainda que tutelados apenas no plano do ius honorarium ${ }^{172}$, parecesse conveniente que o proprietário dispusesse de uma garantia necessariamente operante no plano do ius civile, e, como tal, seguramente tutelada em via jurisdicional ${ }^{173}$.

É verdade, por outro lado, que a prestação de uma stipulatio, com o consequente nascimento de um oportere a cargo do comprador, poderia também ser realizada com atraso.

Para estes casos, o formulário previa o surgimento de uma prerrogativa, análoga ao penhor ${ }^{174}$ e em favor do vendedor, sobre os bens levados pelo comprador ao imóvel. Tal situação se estenderia pelo período em que não se verificasse o pagamento do preço ou, alternativamente, uma equivalente forma de satisfação do crédito $^{175}$.

Também a querer prescindir do fato de que o vendedor não tinha, a rigor, a disponibilidade material dos bens vinculados a garantia de seu crédito ${ }^{176}$, tem-se que tal garantia se extinguia simplesmente para resolver-se "nel diritto, tutelato tramite autorizzazione ad azioni di forza e rimedi interdettali pretori, di tenersi o prendere in ostaggio beni del debitori, ${ }^{\prime 177}$.

Além disso, fica claro que o instituto descrito por Catão parece ser desprovido das características mais fundamentais do penhor - ao menos daquelas que, como já mencionamos, teriam sido sucessivamente elaboradas pela jurisprudência romana mais tardia, a fim de assegurar uma maior satisfação ao credor.

${ }^{172}$ Cf. M. TAlamanCA, La tipicità cit. (nt. 169 supra), p. 56; C. Ferrini, Sull'origine del contratto di vendita in Roma, in Opere di Contardo Ferrini III, Milano, Hoepli, 1929, p. 194. Contra - cf. P. F. GIRARD, Manuel élémentaire cit. (nt. 26 supra), p. 571; F. GALlo, In tema di origine della compra-vendita consensuale, in SDHI 30 (1964), p. 305.

${ }^{173}$ Cf. A. Burdese, Catone cit. (nt. 129 supra), p. 272. No mesmo sentido - cf. Veja, ainda, E. CHAMPEAUX, Le príncipe de simplicité des anciens actes juridiques romains et le gage, in Mélanges P. F. Girard: études de droit romain dédiées a P. F. Girard à l'occasion du 60 anniversaire de as naissance (26 octobre 1912), v.1, Paris, 1912, pp. 42 e ss.

${ }^{174}$ A opinião há muito prevalente é a de que a garantia prevista nos formulários catonianos sobre os invecta et illata não deva ser identificada como um verdadeiro e próprio penhor - cf. W. KUNKEL, Hypothesen zur Geschichte des römischen Pfandrechts, in SZ 90 (1973), p. 152.

${ }^{175}$ Cf. P. FrEZZA, I formulari catoniani cit. (nt. 129 supra), p. 440.

${ }^{176} \mathrm{Cf}$., sobre este ponto, A. MANGIK acredita tratar-se de um "besitzloses Pfand" - cf. Pignus, in RE 20 (1941), pp. 1246 e ss. No mesmo sentido, cf. A. BURDESE, "Lex commissoria” cit. (nt. 26 supra), p. 101.

${ }^{177}$ Cf. A. BURDESE, Pegno, in ED 32 (1982), p. 665. 
No entanto, não seria grande absurdo pensar $^{178}$ (sempre em um nível especulativo, dada a imprecisão e escassez das fontes que confirmariam a ideia ${ }^{179}$ ) que, nos formulários, já se encontraria o mais antigo testemunho, mesmo que ainda tecnicamente imperfeito, de uma figura embrionária do instituto pignoratício $^{180}$.

De qualquer modo, ainda que não se possa identificar no texto a existência de uma lex commissoria pignoribus ${ }^{181}$ propriamente dita, é bastante interessante o mecanismo negocial previsto pelos formulários catonianos para obter um meio de reforçar a obrigação.

Ali, o negócio trazido adquire um caráter dúplice: de um lado, estabelece a prestação de uma promessa verbal; de outro, na falta desta última, tem-se a construção de uma espécie de garantia que cairia sobre os illata colocados no terreno do proprietário vendedor.

Oras, feitas tais considerações em relação aos formulários catonianos, ainda resta uma questão fundamental, qual seja, a de melhor definir a partir de quando teria sido a lex commissoria aplicada à figura do penhor.

Sem recorrer aos mencionados formulários, M. KASER ${ }^{182}$ sustenta a hipótese de que, em se tratando de penhor, ao menos em idade remota, a coisa dada caísse automaticamente na propriedade do credor insatisfeito. Para tanto, elenca como principais argumentos:

a) A polissemia substantivo pignus, que poderia ser empregado, ainda que não tecnicamente, com o significado de reserva. Também neste sentido, a coisa se tornaria propriedade da parte contrária ${ }^{183}$;

b) A existência de um chamado "Ersatzpfand", com base nas observações de W. KUNKEL ${ }^{184}$ sobre a hipótese de que um credor e um devedor

${ }^{178}$ Cf., ad. es., A. BuRdese, Pegno cit. (nt. 177 supra), p. 665.

${ }^{179} \mathrm{E}$, ainda assim, coerente com a crítica de M. SARGENTI - cf. nota 33.

${ }^{180}$ Cf., nesse sentido, A. BURDESE, Pegno cit. (nt. 177 supra), p. 664.

181 Não se encontrava traços evidentes nem da lex commissoria, nem do ius vendendi do credor. Sobre estes - cf., especialmente, A. BURDESE, "Lex commissoria”" cit. (nt. 26 supra), pp. 110 e ss.

${ }^{182}$ Studien cit. (nt. 87 supra), p. 244.

${ }^{183}$ Contra - cf. B. NoORdRAVEn, Pomp., D. 13, 7, 6 pr. cit. (nt. 92 supra), p. 250.

${ }^{184}$ Hypothesen cit. (nt. 114 supra), p. 150. 
convencionassem que o preço pudesse ser pago, alternativamente, com bens de valores estimados. Analogamente, M. KASER entende plausível a transferência automática de propriedade de uma coisa dada em penhor pelo fato de que, ali, o credor recebe, em lugar de dinheiro, a propriedade dos bem (de modo que também a existência de um "Verfallpfand" seria provável) ${ }^{185}$;

c) Em outros sistemas jurídicos antigos, como o grego e o grecoegípcio, institutos análogos comportavam a transferência da propriedade ${ }^{186}$;

Essa construção do autor, ainda que pudesse ser aceita, seria compatível apenas com tempos bastante primitivos ${ }^{187}$. Não peca, contudo, pelo absurdo.

Afinal, sendo a posse o ponto nevrálgico do instituto e tendo sido ele construção mais recente do que a antiga fiducia, é certo que ao credor pignoratício é alheia a utilização de quaisquer dos modos solenes de transferência da propriedade.

Em outras palavras, mesmo quem compra uma res mancipi não pode adquirir sobre esta qualquer outro tipo de domínio que não seja in bonis. Em caso de inadimplemento, a transferência da propriedade, então, poderia se considerar “imediata" (uma vez que a coisa já se encontrava na posse do credor).

De fato, sobretudo pela influência exercida, em tempos mais remotos, pela fiducia cum $_{\text {creditore }}{ }^{188}$, então forma de garantia predominante, é plausível

${ }^{185}$ Segundo B. NOORDRAVEN há, porém, uma grande diferença entre os dois pactos. Em caso de um "Ersatzpfand", o credor, após o termo, tem uma pretensão em relação ao devedor para o dinheiro ou para os bens, em caso de um "Verfallpfand” ele se torna certamente proprietário dos bens entreguesem penhor. A existência de um "Ersatzpfand" não é, então, prova suficiente para que se possa afirmar que no penhor se verifica uma imediata passagem de propriedade ao credor cf. Pomp., D. 13, 7, 6 pr. cit. (nt. 92 supra), p. 251.

${ }^{186} \mathrm{Na}$ verdade, tal argumento não apenas carece de melhor fundamento, como o próprio autor se contradiz, ao afirmar em outra passagem que no direito grego e no direito greco-egípcio se encontram exemplos de uma coisa penhorada, que segue apenas conservada (não há, portanto, transferência) - cf. Studien cit. (nt. 87 supra), p. 246.

${ }^{187} \mathrm{O}$ próprio M. KASER assinala que no direito mais desenvolvido há necessidade de uma lex commissoria expressa - Studien cit. (nt. 87 supra), p. 251.

${ }^{188}$ De modo um pouco exagerado, N. HERZEN defende que o pignus, em origem, antes mesmo que obtivesse proteção jurídica, assim como a fiducia cum creditore, teria o escopo de exercitar uma pressão psicológica para, indiretamente, forçar o devedor ao adimplemento - cf. Origine de l'hypothèque cit. (nt. 26 supra), p. 55. Contra - cf. A. Burdese, "Lex commissoria” cit. (nt. 26 supra), p. 111. 
que lex commissoria possa ter, inicialmente, sido entendida como elemento natural do instituto.

No entanto, certo é que, com o desenvolvimento do ordenamento jurídico romano, já no período clássico ${ }^{189}$ tenha surgido o costume de fazer um pacto expresso em tal sentido, passando a lex commissoria a ser exceção, não $\operatorname{regra}^{190}$.

Em resumo, a lex commissoria, enquanto possa ser apresentada como um elemento essencial na fiducia cum creditore, dada a estrutura do instituto, aparece no penhor como um elemento acessório, como um pacto que, mesmo incidindo sobre a natureza do negócio e sobre seus efeitos, não deixa de ser secundário.

1.2.3. NA HIPOTECA: A disCUSSÃo SOBRE A PRESENÇA DA LEX COMMISSORIA PIGNORIBUS EM P. FLOR. 1 (DE 153 D.C.)

Com o financiamento da Società Italiana per la Diffusione $e$ l'Incoraggiamento degli Studi Classici (a partir de 1950, Associazione Italiana di Cultura Classica), E. SCHIAPARELLI descobre, no Egito ${ }^{191}$, o primeiro de uma

${ }^{189}$ Contra - cf. A. MANigiK , Pignus cit. (nt. 176 supra), p. 1270.

190 Em Iav. 15 ex Cassio, D. 47, 2, 74, se parte do pressuposto que um credor, que não realizou uma lex commissoria, não se torne proprietário: se ele vende o penhor, comete um furto.

Iav. 15 ex Cassio:

Si is, qui pignori rem accepit, cum de Se aquele que recebeu a coisa em <virtude vendendo pignore nihil convenisset, vendit, da garantia do > penhor a tenha vendido ou aut ante, quam dies venditionis veniret celebrou <a venda> antes que se verificasse pecunia non soluta, id fecit. furti se obligat. o termo, não sendo acordado <entre as partes $>$ nada sobre a venda da coisa dada em penhor, é tido <como autor> de furto.

${ }^{191}$ O papiro foi comprado em Guizé tendo o vendedor, na ocasião, indicado Hermópolis, capital da atual região grega de Siro, como lugar de sua proveniência - cf. G. VITELLI, Atene e Roma - Bullettino della Società Italiana per la Diffusione e l'Incoraggiamento degli Studi Classici, n. 27, Firenze, Società Italiana per la Diffusione e l'Incoraggiamento degli Studi Classici, 1901, p. 78. 
sequência posteriormente denominada "papiros florentinos"192, publicado em 1901 por G. VITELLI ${ }^{193}$.

Tal papiro torna-se interessante ao nosso tema à medida que, segundo uma corrente doutrinária mais antiga ${ }^{194}$, traria em seu conteúdo um exemplo de lex commissoria acessória ao instituto da hipoteca.

Sem a pretensão de trazer uma aprofundada análise exegética, acredita-se de interessante valia ao presente trabalho a mera exposição da discussão - como ver-se-á adiante, já pacificada ${ }^{195}$ - sobre a presença ou não da lex commissoria no mencionado papiro grego ${ }^{196}$.

Diferentemente do que ocorre com muitos papiros, o P. Flor. 1 (de 153 d.C.) chegou à modernidade em sua quase integralidade ${ }^{197}$, sendo pouco significativas as discussões sobre as lacunas de seu texto ${ }^{198}$.

192 São assim chamados porque a maior parte desses encontra-se conservada em bibliotecas florentinas - cf. D. CoMPARETti - G. Vitelli, Papiri Greco-Egizii - Papiri Fiorentini Documenti pubblici e privati dell'età romana e bizantina, v. 1, Milano, Hoepli, 1906, p. V. Atualmente, a Biblioteca Medicea Laurenziana di Firenze conserva 386 de 391 desses papiros, incluindo aquele que ora estudamos.

${ }^{193}$ Cf. Atene e Roma cit. (nt. 191 supra), pp. 74 e ss. Há também uma edição posterior do mesmo autor - cf. D. ComparetTI, G. Vitelli, Papiri Greco-Egizii cit. (nt. 192 supra), p. 3 e ss.

${ }^{194}$ Cujo principal representante foi C. WESSELY - cf. Die Stadt Arsinoe (Krokodilopolis) in griechischer Zeit, in Sitzungsberichte der philosophisch-historischen Classe der kaiserlichen Akademie der Wissenschaften zu Wien, Wien, Carl Gerold \& Sohn, 1901, pp. 21 e ss.

${ }^{195}$ Nesse sentido - cf. A. BURDESE, "Lex commissoria” (nt. 26 supra), p. 111.

196 Tendo em vista os objetivos do presente trabalho, que, como se extrai do próprio título, visa tão somente a análise da lex commissoria no direito romano, não se pretende, aqui, uma análise aprofundada do fragmento, tampouco de institutos relativos às garantias reais em direito grego. A propósito, além das obras citadas ao longo deste subitem - cf. L. BREAUCHET, Histoire du droit prive de la republique athénienne, v. 3, Paris, Marescq Ainé, 1855, pp. 176 e ss.; R. DE RUGGIERO, Il divieto di alienazione del pegno nel diritto greco e romano - Contributo papirologico, Roma, L`Erma di Bretschneider, 1910, pp. 23 e ss.; A. MANIGK, Gräko-ägyptisches Pfandrecht, in SZ 30 (1909), pp. 272 e ss.; L. RAAPE, Der Verfall des griechischen Pfandes besonders des griechisch-ägyptischen, Halle, David Brown Book Company, 1912, pp. 13 e ss.; E. RABEL, Die Verfügungsbeschränkungen des Verpfänders besonders in den Papyri, Lipsia, University of California Libraries, 1909, pp. 9 e ss.

${ }^{197}$ Quando da publicação do papiro, em 1901, G. VITELLI afirma jamais ter visto um papiro tão completo e legível em seu inteiro teor como esse - cf. Atene e Roma cit. (nt. 191 supra), p. 75.

${ }^{198}$ De fato, nos principais trabalhos que tratam do tema, as discussões jurídicas pouco levam em conta as poucas lacunas presentes no texto - cf. D. COMPARETTI, G. ViTELLI, Papiri Greco-Egizii - Papiri Fiorentini - Documenti pubblici e privati dell'età romana e bizantina, v. 1, Milano, Hoepli, 1906; O. GRADENWITZ, Einfuhrung in Die Papyrusk, German, Nabu Press, 2010, p. 85; C. WESSELY, Die Stadt Arsinoe (Krokodilopolis) in griechischer Zeit, in Sitzungsberichte der philosophisch-historischen Classe der keiserlichen Akademie der Wissenschaften zu Wien, Wien, Carl Gerold \& Sohn, 1901; H. F. HITZIG, Das griechische Pfandrecht, München, Arno, 1895, pp. 108 e ss; L. BREAUCHET, Histoire cit. (nt. 196 supra), pp. 252 e ss; U. E. PAOLI, Ipoteca (diritto attico), Nuovo Digesto Italiano, v. 17, Torino, Torinese, 1938. 
Ali é apresentado um contrato de mútuo, garantido com hipoteca, datado de 25 de março de 153 d.C. São partes a mutuária Ptolema e a mutuante Hermione ${ }^{199}$. A hipoteca é gravada sobre a quarta parte de um imóvel situado em Tekerkethothis e garante o capital de 200 dramas $^{200}$, a serem pagos em dois anos, com a taxa fixa de $12 \%$ ao ano sobre o valor do inteiro capital inicial. Assim, ao todo, o valor do mútuo passa a ser de 248 dramas.

Entre a mutuária e a mutuante é pactuado que, faltando a restituição do capital e da respectiva taxa no termo estabelecido, poderá a mutuante apropriar-se da coisa hipotecada como se proprietária fosse ${ }^{201}$.

Ao comentar brevemente o texto logo após o advento de sua publicação, C. WESSELY ${ }^{202}$ aponta a transferência da propriedade à mutuante como um característico exemplo de lex commissoria pignoris.

A ideia teve por principal opositor E. CosTA ${ }^{203}$, para o qual C. WESSELY, de modo precipitado, desconsiderou que se tratava, em verdade, da hipoteca grega. Este é o pensamento que ora predomina ${ }^{204}$.

O pergaminho, bastante longo, tem aproximadamente 1 metro de largura e $23 \mathrm{~cm}$ de altura, sendo escrito apenas em um dos lados. Os primeiros sete centímetros à esquerda são margens vazias, com uma simples anotação ilegível, da qual restam apenas poucas letras. Por 78 centímetros se estende o documento principal e por 15 centímetros uma espécie de compêndio, por

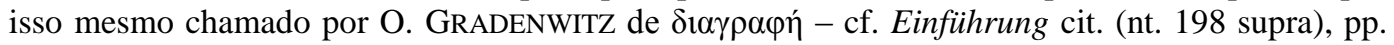
129 e 141.

As primeiras 11,5 linhas da primeira parte e as primeiras 10 linhas da segunda parte são escritas em um grego cursivo irregular, sendo provável que derivem de pessoa diversa. Já o restante do documento é escrito com a mesma caligrafia bastante regular, o que indica ter sido feito pelo oficial que registrou o ato - cf. Atene e Roma cit. (nt. 191 supra), p. 74.

199 No ato, Ptolema e Hermione foram assessoradas por seus pais Horion e Eudaimon, respectivamente. Há controvérsia doutrinária sobre se o avô de Ptolema também apareceria no papiro, pelo fato de o nome Horion repetir-se por duas vezes ao longo do papiro (linha s_e _). Qualquer seja a posição escolhida, contudo, não há dúvidas de que realizou o ato com o auxilio de

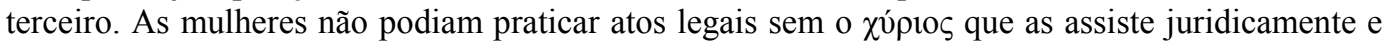
as representa; a nossa palavra tutor teria sentido demasiadamente restrito - cf. O. GRADENWITZ, Conjecturen cit. (nt. 96 supra), p. 128.

${ }^{200}$ G. VITELLI, na editio princeps, alega não esconder uma "certa ingenua maraviglia" pelo fato de tanta solenidade e completeza de fórmulas ter sido adotada para um empréstimo de apenas 200 dracmas, correndo-se o risco de que as despesas contratuais superassem a quantia do empréstimo - cf. Atene e Roma cit. (nt. 191 supra), p. 74.

${ }^{201}$ Um contrato análogo do ano 103, da mesma cidade e com as mesmas fórmulas também foi publicado pela Società Italiana per la Diffusione e l'Incoraggiamento degli Studi Classici - cf. Atene e Roma - Bullettino della Società Italiana per la Diffusione e l'Incoraggiamento degli Studi Classici, n. 59, Firenze, 1903, pp. 333 e ss. Trata-se do Pap. Flor. 81 (de 103 d.C.), que igualmente trata de uma relação de mútuo de dinheiro com hipoteca. No mesmo sentido - cf. Pap. Flor. 28 (de 179 d.C.)

${ }^{202}$ Die Stadt Arsinoe cit. (nt. 198 supra), p. 24. 
Para melhor compreender o raciocínio do autor, é necessário considerar algumas peculiaridades da hipoteca grega, cuja configuração é bastante diversa daquela romana ${ }^{205}$. Isso porque, tendo suas origens na $\pi \rho \tilde{\alpha} \sigma 1 \varsigma$ غ̇ंì $\lambda u ́ \sigma \varepsilon 1 \mathrm{e}$ sobre ela estruturada, apresenta a natureza de uma datio in solutum tacitamente pré-convencionada ${ }^{206}$.

O instituto implicaria, por si só, a faculdade para o credor insatisfeito de apropriar-se da coisa, com a consequente faculdade de vendê-la e obter por inteiro o preço, ainda se exorbitante ao total do crédito garantido ${ }^{207}$.

Por isso, a eventual aposição da lex commissoria à hipoteca de direito grego não teria valor outro que o de (a) reconhecer expressamente efeitos que já lhe fossem implícitos, independentemente de qualquer acordo acessório, ou, ainda, (b) exonerar o credor da prática de determinados atos que, sem a lex, seriam necessários para apropriar-se da coisa.

Para E. CosTA ${ }^{208}$, é precisamente esse o alcance do texto apresentado no papiro, o que se confirmaria de dois principais modos:

a) Através de fórmulas e esquemas próprios à hipoteca grega, como,

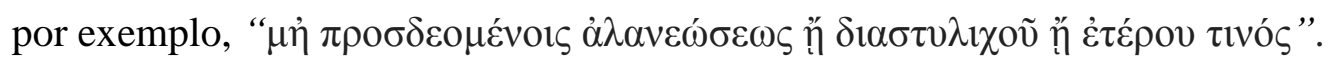

b) Com a peculiar cláusula contida no papiro, pela qual a mutuária, após ser obrigada a conservar os bens - sendo expressamente impedida de vendêlos ou empenhá-los a terceiros -, compromete-se a restituir à mutuante o capital e

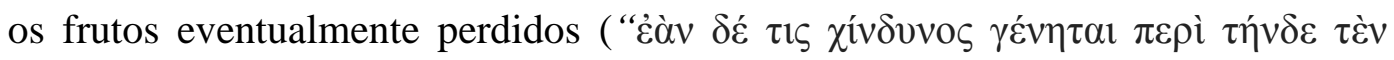

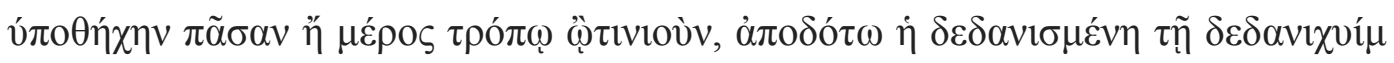

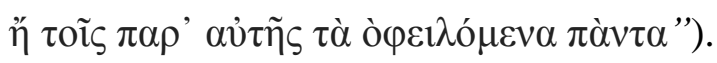

${ }^{203}$ Sul papiro fiorentino num. 1, BIDR 14 (1901), p. 3.

${ }^{204}$ Nesse sentido, V. LOJACONO, Il patto commissorio nei contratti di garanzia, Milano, Giuffrè, 1952, p. 8.

${ }^{205}$ Sobre a recepção da hipoteca no direito romano - cf., especialmente, A. BISCARDI, Le garanzie reali del credito, Siena, Giubbi \& C., 1957, p. 202.

${ }^{206}$ Cf. H. F. HitZIG, Das griechische cit. (nt. 198 supra), pp. 108 e ss; L. BREAUCHET, Histoire cit. (nt. 198 supra), pp. 252 e ss.

${ }^{207}$ Cf. U. E. PAOLI, Ipoteca cit. (nt. 198 supra).

${ }^{208}$ Sul papiro fiorentino num. 1, BIDR 14 (1901), p. 3. 
De fato, em relação à hipoteca romana esta última construção não teria sentido. Verificado o termo, o crédito continua sendo exigível ${ }^{209}$, sendo a entrega da coisa em garantia medida apenas secundária para a satisfação do credor ${ }^{210}$.

A teoria de E. CosTA, vale ressaltar, encontrou posterior respaldo nos estudos de H. F. HITZIG ${ }^{211}$, para o qual a hipoteca grega implicaria no direito de ter a posse da coisa hipotecada apenas ao término do prazo acordado ${ }^{212}$.

Neste caso, com a tomada de posse ( $\dot{\varepsilon} \mu \beta \alpha ́ \tau \varepsilon v \sigma 1 \varsigma)$ da coisa, o credor lhe adquire imediatamente a propriedade e, consequentemente, extingue-se a obrigação então garantida pela hipoteca (Pfandverfall) ${ }^{213}$.

${ }^{209}$ Cf., nesse sentido, A. BISCARDI, Le garanzie, cit. (nt. 205 supra), pp. 205 e ss.

${ }^{210}$ Por outro lado, na hipoteca grega, a expressão óv $\tau_{\imath}$ ò $\varphi \varepsilon \imath \lambda o \mu \varepsilon ́ v \omega v$, através da qual a mutuária declara de acordar à mutuante de tomar posse da coisa hipotecada, na falta de sua parte a restituição do mútuo, seria perfeitamente compatível com essa substituição - cf. E. Costa, Sul papiro cit. (nt. 203 supra), p. 5.

${ }^{211}$ H. F. HiTZIG, Das griechische cit. (nt. 198 supra), p. 257.

${ }^{212}$ H. F. HiTZIG, Das griechische cit. (nt. 198 supra), p. 257.

213 A teoria de U. E. PAOLI acaba sendo especialmente interessante na medida em que

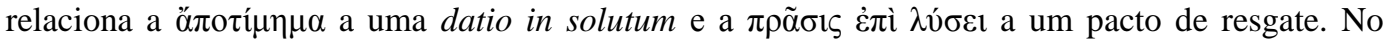
primeiro caso, não tem o credor o direito de vender a coisa hipotecada, mas pode dela se apropriar; quanto aos efeitos, tem o caráter que Hitzig reconhecia à hipoteca grega de Pfandervall. No segundo caso, por outro lado, mediante tal venda a propriedade e o ius possidendi da coisa vendida passava ao credor, e o devedor continuava a deter a coisa vendida conservando dentro de um certo termo o direito a readquiri-lo. Isso porque essa venda justificava-se para garantir uma obrigação, que em relação à própria venda era principal. $\mathrm{O}$ autor ressalta, contudo, que no direito ático, a

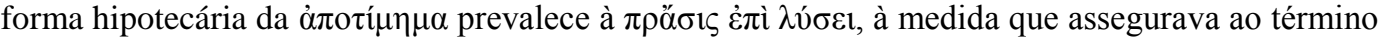
do prazo uma situação definitiva ao patrimônio do credor e do devedor - cf. Ipoteca cit. (nt. 198 supra). 


\subsection{IUS DISTRAHENDI ${ }^{214}$ COMO ALTERNATIVA À SEVERIDADE DOS EFEITOS COMISSÓRIOS}

$\mathrm{O}$ ius distrahendi faculta ao credor a venda da coisa entregue em garantia a terceiros sem que, em razão disso, sofra as consequências de uma actio directa $^{215}$.

O pacto, assim como a lex commissoria, prevê um meio de satisfação direta sobre a garantia em caso de inadimplemento. Daí acreditarem alguns autores $^{216}$ que seja concluído exclusivamente em favor do credor, sem considerarem que também o devedor pode dele beneficiar-se. É o que ocorre, e.g., quando a garantia tem maior valor do que o débito principal.

As principais vantagens do instituto, portanto, são basicamente duas: (a) permite ao devedor inadimplente reaver a diferença entre o valor da coisa e o total do crédito garantido, e (b) propicia a satisfação do credor nos casos em que o valor da coisa seja insuficiente para cobrir o próprio crédito $^{217}$.

Dadas as substanciais diferenças existentes entre a fiducia cum creditore, de um lado, e o penhor e a hipoteca, de outro, torna-se conveniente a análise apartada de ambos os casos.

${ }^{214}$ O termo também é usado como sinônimo de pactum vendendi pelos trabalhos que cuidam do tema (ainda que de modo incidental) - cf., entre outros, L. CHADEL, Étude sur le "jus distrahendi" dans la fiducie le gage et l'hypothèque, $1^{\mathrm{a}}$ ed., Paris, Nouvelle, 1902, pp. 10-11; R. JACQUELIN, De la fiducie cit. (nt. 82 supra) pp. 191 e ss; P. DE FRANCISCI, Il trasferimento cit. (nt. 72 supra), pp. 257 e ss.; E. AlBERTARIO, La terminologia cit. (nt. 138 supra), p. 582; C. LONGO, Corso di diritto romano cit. (nt. 46 supra), p. 48; G. SEGRÈ, Corso cit. (nt. 72 supra), p. 48 e ss.; A. BURDESE, "Lex commissoria”" cit. (nt. 26 supra), p. 25.

${ }^{215}$ Cf. L. CHADEL, Étude cit. (nt. 214 supra), pp. 10-11.

${ }^{216}$ Para R. JACQUELIN, isso fica claro com o verbo cavere em Pomp. 35 ad. Sab., D. 13, 7, 6 pr. ("...quia tua causa id caveatur") - cf. De la fiducie cit. (nt. 82 supra), pp. 273-274. No mesmo sentido, "Lex commissoria" cit. (nt. 26 supra), pp. 137-138. Contra, J. J. BACHOFEN, Das römische Pfandrecht, Basel, Schweighausersche, 1847, pp. 191 e ss.; H. DERNBURG, Das Pfandrecht nach den Grundsätzen des heutigen römischen Rechts, v. 2, Leipzig, Hirzel, 1864, pp. 110-ss, 157-ss. 191-ss.; P. DE FRANCISCI, Il trasferimento cit. (nt. 72 supra), pp. 257 e ss.; . ALBERTARIO, La terminologia cit. (nt. 138 supra), p. 582.

${ }^{217}$ Para A BURDESE, uma regulamentação tão complexa, fundada em princípios equitativos e que tem, em última medida, base no "ut inter bonos bene agier" ciceroniano, revela um grau bastante refinado de elaboração jurídica - cf. A. BURDESE, “Lex commissoria” cit. (nt. 26 supra), p. 25. 
Antes, porém, apresentam-se as principais questões relativas ao ius distrahendi que se pretende responder: (a) se pôde ele ter lugar já na fiducia; (b) a partir de que momento e por que razões tornou-se elemento natural do penhor e da hipoteca; (c) quais foram os reflexos dessa transição no instituto comissório ${ }^{218}$.

Quanto à fiducia cum creditore, parece não haver muita discussão. É unânime a opinião dos doutrinadores ${ }^{219}$ pela compatibilidade do ius distrahendi com o negócio jurídico fiduciário, independentemente de acordo expresso entre as partes.

Isso porque, sendo a transferência da propriedade efeito essencial da fiducia em caso de inadimplemento, passa o credor a ter poderes tão amplos sobre a coisa quanto aqueles inerentes ao comprador em qualquer modalidade válida de venda. A faculdade de alienar a coisa a um terceiro, portanto, nada mais seria do que um mero exercício de tais poderes.

A liberação da responsabilidade do credor que, insatisfeito ao término do prazo, vende a coisa resulta do "ut vendere liceret" ${ }^{\prime 220}$, sendo a venda fiduciária justificada "ex pactione ${ }^{\text {"221 }}$. Para A. BURDESE ${ }^{222}$, o emprego do verbo licere nas fontes traria duas importantes consequências:

a) Em origem, teria ius distrahendi sido introduzido como um meio alternativo à satisfação do credor, que, como regra, já seria beneficiado pela mais antiga lex commissoria ${ }^{223}$.

b) Tendo as partes optado pelo ius distrahendi, no entanto, não seria possível a aplicação concomitante da lex commissoria, pela contradição de efeitos

218 Se comparado à lex commissoria, o ius distrahendi é trazido nas fontes de modo bastante claro, em virtude da ampla aceitação com que contou o instituto - cf., e.g., Ulp. 41 ad Sab., D. 13, 7, 4; Pomp. 35 ad. Sab., D. 13, 7, 6 pr.; Pomp. 35 ad. Sab., D. 13, 7, 6, 1; Paul. 2 sent., D. 13, 7, 8 pr., Paul. 2 sent., D. 13, 7, 8, 1; Paul. 2 sent., D. 13, 7, 8, 2; Paul. 2 sent., D. 13, 7, 8, 3; Paul. 2 sent., D. 13, 7, 8, 4; Paul. 2 sent., D. 13, 7, 8, 5.

${ }^{219}$ Cf. C. Longo, Corso di diritto romano cit. (nt. 46 supra), p. 48. De mesma opinião cf., entre outros, G. SEGRÈ, Corso cit. (nt. 72 supra), p. 133.

${ }^{220}$ Cf. Pomp. 35 ad. Sab., D. 13, 7, 6 pr. ("...ut fundum pigneraticium tibi vendere liceret..."). No mesmo sentido, a Formula Baetica em sua parte final - cf. item 1.3.1.

${ }^{221}$ Cf. Pomp. 35 ad. Sab., D. 13, 7, 8, 5 ("Cum pignus ex pactione venire potest... ").

222 Pp. 26-27.

${ }^{223}$ G. GROSSO - a nosso ver, acertadamente - vai além, ao considerar que o ius distrahendi tenha sido, em origem, uma variação do conteúdo do pacto comissório destinada a reforçar o escopo satisfativo da fiducia cum creditore - cf. Appunti sulla formula dell'actio fiducia, in Annali dell'Università di Camerino, 3 (1929), p. 108. 
que ambos os pactos apresentariam, caso verificada a condição "si soluta pecunia non sit" $^{\prime 224}$.

Assim, contrapostos o pactum vendendi e a lex commissoria, no caso de inexigibilidade de restituição da coisa ao devedor pela falta do pagamento, teriam as partes a faculdade de escolher entre um ou outro pacto e seus correspondentes efeitos. $\mathrm{Na}$ ausência de acordo prévio, todavia, pressupunha-se a existência do pacto comissório ${ }^{225}$.

A posição mais aceita $^{226}$ é a de que, com o tempo, tenha-se deixado paulatinamente de aplicar a lex commissoria na fiducia em detrimento do pactum vendendi, a ponto de - embora não ter sido considerado elemento natural do instituto $^{227}$ - a opção pelo "vendere licere" ter se tornado a regra na fórmula que estabelecia o pactum fiduciae ${ }^{228}$.

Já no que diz respeito ao penhor e à hipoteca, é incerto se a eles primeiro foi conhecida a lex commissoria ou o ius distrahendi ${ }^{229}$, pelo fato de ambos os pactos já serem então aplicados ao negócio fiduciário ${ }^{230}$. Certo, porém,

${ }^{224}$ Segundo A. BURDESE, essa contradição muitas vezes dá lugar à interpretação de que o ius distrahendi, na verdade, consistiria numa restrição à eficácia da lex commissoria, ao estabelecer a impossibilidade de que o credor fique com a coisa - cf. "Lex commissoria" cit. (nt. 26 supra), p. 26. A hipótese, no entanto, seria absurda. Entender a obrigação de venda da res como uma mera limitação do direito de propriedade é absolutamente incompatível com a finalidade satisfativa do credor - através justamente da transferência da coisa - que caracteriza a lex commissoria.

${ }^{225}$ Tal que se poderia dizer dever-se concluir entre a fiducia cum creditore com o recorrer ou à lex commissoria ou ao pactum vendendi, com o qual se dá como pressuposto o condicionamento soluta pecunia da obrigação de restituir - cf. A. BURDESE, "Lex commissoria" cit. (nt. 26 supra), p. 28.

${ }^{226}$ Cf. C. LONGO, Corso di diritto romano cit. (nt. 46 supra), p. 48; A. BURDESE, "Lex commissoria" cit. (nt. 26 supra), p.27.

${ }^{227}$ Cf. G. GROSSO, Appunti cit. (nt. 223 supra), p. 108. Contra, A. BuRDESE, para o qual se antes os contraentes deviam fazer expressa menção ao "vendere licere" e cláusulas anexas para evitar os efeitos da lex commissoria, com o tempo, é esta última que passa a representar um desvio expresso do normal regime de venda "si ad diem pecunia soluta non sit". Adicionalmente, a única possibilidade de excluir a função satisfativa do instituto teria sido dada à conclusão de um expresso pactum de non distrahendo - cf. A. BURDESE, "Lex commissoria” cit. (nt. 26 supra), p. 28. Nesse sentido - cf. V. DeVILlA, L’ius distrahendi nella fiducia e nel pignus, Sassari, Galizzi, 1937, p. 3. Para que o pactum de non distrahendo pudesse ser considerado ineficaz, era necessário que o devedor fosse intimado três vezes pelo credor - cf. P.S. 2, 5, 1 ("...ter ante denuntiare debitori suo debet...").

${ }^{228}$ É, de fato, o que se verifica nos documentos pompeiano e bético - cf. item 1.2.1.

229 A primeira menção a este faz referência a Sérvio em Ulp. 77 ad ed., D. 47, 10, 15, 22.

${ }^{230}$ No direito justinianeu, como se verá, o ius distrahendi é essencial ao penhor e não pode ser excluído sequer por pactos contrários (no caso, o pacto de non distrahendo, que traz o requisito 
é que seu regime passou do ius distrahendi expresso, por meio do pacto adjeto, ao tácito - antes mesmo de ter a lex commissoria sido proibida.

No direito romano clássico, a eficácia do ius distrahendi pressupunha a existência de um pactum de distrahendo pignore, por meio do qual era o credor autorizado a alienar o bem ${ }^{231}$. Assim, a exemplo do que ocorria na fiducia cum creditore, a venda da coisa entregue em garantia dependia do acordo expresso das $\operatorname{partes}^{232}$.

Caso a alienação fosse efetuada na ausência de tal acordo - e, portanto, sem o consentimento do devedor - incorreria o credor em furto ${ }^{233}$. A hipótese não deveria ser tão incomum, a ponto de ter justificado o fragmento de Javoleno. Isso porque, a princípio, o credor, pignoratício ou o hipotecário, não

da tríplice denúncia - cf. Ulp. 41 ad Sab., D. 13, 7, 4). Para V. DEVILLA, deve-se entender que tal regime já seria encontrado no direito clássico com a fidúcia, tendo sido posteriormente transportado para o penhor pós-clássico - cf. L'ius distrahendi cit. (nt. 227 supra), p. 22. De qualquer modo a gradual passagem do regime da fidúcia ao penhor pós-clássico, seja no que diz respeito ao ius distrahendi, seja no que diz respeito à condictio furtiva (que Aristão acordava ao credor fiduciário é consentida no direito de Justiniano também ao credor pignoratício, ainda que ele não possa ser considerado dominus da coisa - cf. Ulp. 39 ad ed., D. 13, 1, 12), já é, por si só, um claro indício que os compiladores justinianeus, entre as passagens relativas à fiducia, escolheram aquelas que ofereciam uma mais fácil adaptação à nova estrutura trazida no penhor cf. V. Devilla, L'ius distrahendi cit. (nt. 227 supra), p. 22.

${ }^{231} \mathrm{~A}$ indispensabilidade de tal pacto no direito clássico era indispensável à venda da coisa penhorada e tem, acima de tudo, uma importância mais histórica, aliada à estrutura da antiga fiducia, do que de cunho prático propriamente dito - cf. V. DEVILLA, L'ius distrahendi cit. (nt. 227 supra), p. 22.

${ }_{232}$ Diferentemente do que ocorreu com a fiducia cum creditore, no entanto, a lex commissoria jamais chegou a ser considerada elemento natural do penhor ou da hipoteca, de modo que, para o credor ter direito de ficar com a coisa para si, era necessária a existência desse pacto cf. J. C. Moreira Alves, Direito Romano, $17^{\mathrm{a}}$ ed., Rio de Janeiro, Forense, 2009, p. 368; A. BURDESE, "Lex commissoria" cit. (nt. 26 supra), p. 27.

${ }^{233}$ Cf. Iavolenus libro 15 ex Cassio, D. 47, 2, 74 (73):

Si is, qui pignori rem accepit, cum de Se aquele, que recebeu como garantia uma vendendo pignore nihil convenisset, coisa, vendeu <essa> coisa não tendo nada vendidit, aut ante, quam dies venditionis sido acordado sobre a venda, ou fez isso veniret pecunia non soluta, id fecit: furti se antes que se verificasse o dia da venda <e> obligat. não tendo sido pago o preço, se obriga ao $<$ meio processual de tutela do $>$ furto.

Em princípio, a alienação efetuada pelo credor era irrevogável, ainda que não fossem estritamente observadas as condições estabelecidas pelo pactum de vendendo - cf. L. CHADEL, Étude cit. (nt. 214 supra), p. 16. 
tinha o direito de ficar com a coisa entregue, nem de vendê-la, a menos que estivesse diante de uma hipótese de ius distrahendi ou lex commissoria ${ }^{234}$.

Aliás, nesse sentido, mesmo as razões pelas quais a venda pudesse ser realizada pelo credor beneficiado pelo ius distrahendi já foram objeto de controvérsias, especialmente entre A. ManigK, P. De Francisci e A. Burdese.

Para A. MANIGK ${ }^{235}$, verificado o inadimplemento, o credor tornar-seia automaticamente proprietário da coisa penhorada ou hipotecada. A ele seria natural, portanto, a faculdade de alienar, pelas mesmas razões que se verificam no regime fiduciário.

P. DE FRANCISCI ${ }^{236}$, acertadamente a nosso ver, considera inaceitável a teoria de A. MANIGK, pelo fato de ser ela contraditória às noções mais básicas sobre a estrutura das garantias reais clássicas ${ }^{237}$. Afinal, a transferência da propriedade com escopo satisfativo é efeito exclusivo da fiducia cum creditore e em nada se confunde com ius retentionis que caracteriza o pignus ${ }^{238}$.

Para o autor ${ }^{239}$, o inadimplemento da obrigação principal implicaria, por parte do devedor, na renúncia à propriedade da coisa em favor do credor. Seus argumentos, no entanto, não encontram qualquer respaldo nas fontes que permita entender pela eventual intenção do devedor em renunciar ao seu bem ${ }^{240}$.

A. BURDESE ${ }^{241}$, por sua vez, defende não se tratar de mera renúncia, mas propriamente de uma autorização tácita por parte do devedor que justificaria o que ele designa por "derroga ai normali principi in tema di legittimazione al trasferimento della proprietà".

${ }^{234}$ Nesse sentido, cf. A. BISCARDI, La Lex commissoria cit. (nt. 22 supra), p. 515.

${ }^{235}$ Cf. A. MANigK, Pignus cit. (nt. 134 supra), pp. 1248 e ss. A tese não é de todo nova: já Cic., De orat., 3, 1, 4 entendia que, desde o início, o credor pignoratício tivesse tido a faculdade de vender, sem necessidade de pacto expresso.

${ }^{236}$ Il trasferimento cit. (nt. 72 supra), pp. 256 e ss.;

${ }^{237}$ No mesmo sentido - cf. A. BURDESE, "Lex commissoria" cit. (nt. 26 supra), p. 132. Para o autor, P. DE FRANCISCI estabelece uma construção incompatível com o caráter possessório do instituto pignoratício e com a sua proteção originariamente interdital - cf. A. BURDESE, "Lex commissoria" cit. (nt. 26 supra), p. 132.

${ }^{238}$ Sobre o ius retentionis, aliás, importa lembrar que, a partir de uma constituição imperial de Gordiano, o credor, mesmo depois de pago o débito em cuja garantia foi dada a coisa em penhor ou hipoteca, tem a faculdade de retê-la em seu poder até que o devedor pague outros débitos a seu favor, ainda que não garantidos - cf. Gord., C. 7, 26,5 (de 238 d.C.).

${ }^{239}$ Il trasferimento cit. (nt. 72 supra), pp. 257 e ss.;

${ }^{240}$ Cf. A. BURDESE, "Lex commissoria” cit. (nt. 26 supra), p. 133.

241 "Lex commissoria" cit. (nt. 26 supra), pp. 138-139. 
A prova estaria no texto de Gai. 2,64, que, ao elencar de modo exemplificativo alguns casos em que a faculdade de alienar é acordada também a quem não é dominus, menciona o credor pignoratício autorizado a exercer o ius distrahendi ex pactione $e^{242}$.

Por fim, como visto alhures, se inicialmente apenas pôde o credor pignoratício ou hipotecário beneficiar-se dos efeitos do ius distrahendi mediante a celebração de um pacto adjeto, isso não já ocorreu no direito justinianeu. Resta, então, saber a partir de quando passou o mencionado pacto a ser considerado elemento natural nas relações de garantia.

Embora não se possa precisar o exato momento, sabe-se que já a partir da época dos imperadores Severii, no século III d.C., o ius distrahendi passou a ser regra: fazia parte do penhor e da hipoteca sempre que as partes não estipulassem em sentido diverso ${ }^{243}$.

A partir de então, portanto, teria sido definitivamente estabelecida a diretiva de conceber o ius distrahendi como um elemento natural do ato constitutivo de um direito real de garantia. No entanto, ainda que fosse considerado elemento natural, não se pode dizer que também fosse essencial ao ato. Afinal, inversamente, era possível excluí-lo mediante um pacto que proibisse a alienação da coisa. É o chamado pactum de non disrahendo pignore ${ }^{244}$.

${ }^{242}$ Cf. Gai. 2, 64 ("...item creditor pignus ex pactione, quamuis eius ea res non sit...").

243 Cf., entre outros, V. Devilla, L’ius distrahendi cit. (nt. 227 supra), p. 4; M. TALAMANCA, Istituzioni cit. (nt. 71 supra), pp. 478-479. No entanto, já autores mais antigos duvidaram que o regime descrito sobre a distractio pignoris não fosse o mesmo entre os clássicos e os justinianeus - cf., nesse sentido, F. EISELE, Beiträge zur Erkenntniss der Digesteninterpolationem, in SZ 11 (1890), p. 298, 304 e ss.; C. FERRINI, Manuale di Pandette, Milano, Libreria, 1900, p. 515; P. F. GIRARD, Manuel élémentaire cit. (nt. 26 supra), E. RABEL, Grundzüge des römischen Rechts, Basel, Benno Schwabe \& Company Verlag, 1955, p. 496; F. Messina Vitrano, Per la storia dell'ius distrahendi, Palermo, Luigi Gaipa, 1910, pp. 4 e ss; F. EBRARD, Die Digestenfragmente ad formulam hypothecariam, München, Veit \& Comp., 1917, p. 127; G. BESELER, Beiträge zur Kritik der rïmischen Rechtsquellen I, Tübingen, Mohr, 1910, p. 83; S. PEROZZI, Istituzioni di Diritto Romano I, Firenze, G. BarberÀ, 1906, p. 817; P. DE FrANCISCI, Il trasferimento cit. (nt. 72 supra), p. 260; B. BIONDI, Istituizioni cit. (nt. 69 supra), p. 324.

${ }^{244}$ Sobre o assunto - cf., especialmente, F. MESSINA VITRANO, Per la storia cit. (nt. 243 supra); F. EBRARD, Die Digestenfragmente cit. (nt. 243 supra); G. BESELER, Beiträge cit. (nt. 243 supra), p. 817; P. F. GIRARD, Manuel élémentaire cit. (nt. 26 supra). 
Tampouco essa regra, supostamente de origem justinianéia ${ }^{245}$, seria, porém, absoluta: era reconhecida ao credor a faculdade de alienar, ainda que estabelecido o pactum de non distrahendo, se, após três tentativas de cobrança junto ao devedor, não obtivesse a satisfação de seu crédito.

A regra seria trazida em Ulp. 41 ad Sab., D. 13, 7, 4, onde se tem, de fato, que sequer o pacto de non distrahendo seria apto a excluir tal faculdade de venda da coisa, caso cumprido o requisito da tríplice denúncia:

Ulpianus libro 41 ad Sabinum, D. 13, 7, 4:

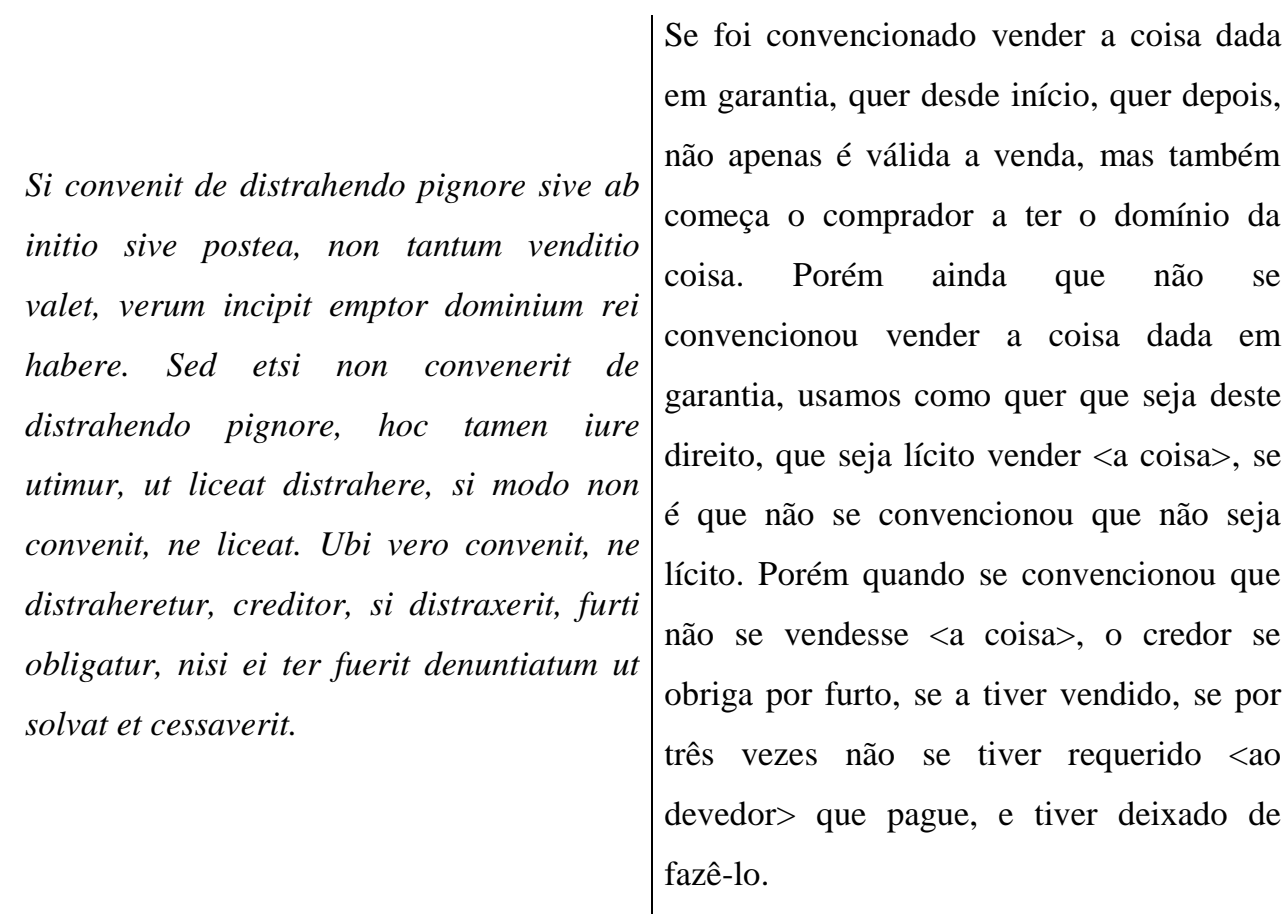

A última parte do fragmento de Ulpiano, "nisi ei ter fuerit denuntiatum ut solvat et cessaverit" (interpolada ${ }^{246}$ ), costuma ser confrontada ${ }^{247}$

${ }^{245}$ Cf. V. Devilla, L'íus distrahendi cit. (nt. 227 supra), p. 4.

${ }^{246}$ Sobre a interpolação em "... nisi ei ter fuerit denutiatum ut solvat et cessaverit..." - cf. P. Bonfante, Corso di diritto romano II - La proprietà I e II (1926), reimpr., Milano, Giuffrè, 1966, p. 454. A interpolação, nesse caso, é fundamental para que se obtenha o sentido supramencionado. Se Ulpiano realmente tivesse acolhido a regra expressa com a proposição limitativa "nisi ei ter", o entendimento sobre a evolução histórica do instituto mudaria complemente, pois já no direito clássico, antes mesmo da época dos Severos e do reconhecimento do penhor como elemento natural, ter-se-ia a regra de que o ius distrahendi é inerente ao pignus e que não pode ser excluída nem mesmo pelo pacto inverso, se o credor observa a formalidade das três denúncias - cf. V. DeVILlA, L’ius distrahendi cit. (nt. 227 supra), p. 5. 
com a semelhante passagem "ter ante denuntiare debitori suo debet" trazida em P.S. 2, 5, $1^{248}$, ao se questionar se poderia, de fato, ser o pactum de non distrahendo considerado uma criação justinianéia.

Embora, a princípio, a presença da regra nos textos de Ulpiano e de Paulo ofereça uma resposta contraditória à questão, há uma importante diferença entre essas passagens que merece ser considerada em qualquer análise: enquanto, por um lado Ulpiano refere-se propriamente a um caso de pactum de non distrahendo, Paulo, por outro, traz a hipótese em que o penhor tenha sido constituído puro, ainda em momento prévio à concepção do pacto como elemento natural do contrato.

Segundo F. MEssina VITRANO ${ }^{249}$, no texto original de Ulpiano, não sendo já o ius distrahendi elemento natural do negócio, as três cobranças ocorriam quando não se fosse expressamente estabelecido o pactum de distrahendo. A frase "nisi ei ter fuerit denuntiatum ut solvat et cessaveri", portanto, seria substancialmente genuína, mas teria sido trocada de lugar. No texto originário, ela se localizaria imediatamente antes de "si modo non convenit, ne liceat".

Já P. BONFANTE ${ }^{250}$, diferentemente, entende que o requisito das três cobranças pelo credor, que já aparece em Paulo, é provavelmente um costume extinto na época pós-clássica, retomado por Justiniano no momento de sua compilação. Tratar-se-ia, assim, de mera escolha legislativa, cujos reflexos práticos já não mais seriam sentidos quando de sua constituição.

Por fim, V. DEVILLA ${ }^{251}$, embora concorde substancialmente com P. BONFANTE, dá razão à afirmação de F. MESSINA VITRANO de que classicamente, como se vê em Paulo, a tríplice denúncia é exigida quando nada se convenciona entre devedor e credor sobre a venda a coisa.

247 Cf., F. Messina Vitrano, Per la storia cit. (nt. 243 supra), p. 35; F. EBRARD, Die Digestenfragmente cit. (nt. 243 supra), pp. 121-122; G. BESELER, Beiträge cit. (nt. 243 supra), p. 817; P. F. GIRARD, Manuel élémentaire cit. (nt. 26 supra), p. 57; V. DEVILLA, L'ius distrahendi cit. (nt. 227 supra), p. 6.

248 "Creditor si simpliciter sibi pignus depositum distrahere velit, ter ante denuntiare debitori suo debet, ut pignus luat, ne a se distrahatur".

${ }^{249}$ Per la storia cit. (nt. 243 supra), p. 5.

${ }^{250}$ Corso cit. (nt. 246 supra), p. 454.

${ }^{251}$ L'ius distrahendi cit. (nt. 227 supra), p. 6. 
O mérito de Justiniano está justamente em elevar o ius vendendi a elemento essencial do penhor, ainda que a ele seja aposto um pacto contrário. Neste caso, a observância da tríplice denúncia dispensaria o credor pignoratício de qualquer responsabilidade.

Assim, tomando por correta a tese de V. DeVILLA ${ }^{252}$ sobre Ulp. 41 ad Sab., D. 13, 7, 4, entende-se lícita a venda da coisa dada em garantia, ainda que acrescido um pacto no sentido oposto, desde que o credor efetue por três vezes a cobrança daquilo que lhe é devido.

Ulpiano, portanto, identifica-se com o pensamento gaiano ${ }^{253}$ ao condicionar a faculdade de alienar, por parte do credor pignoratício, a um pacto que expressamente autorizasse a transferência. No mesmo sentido, também alinhava-se à Javoleno, ao entender que a alienação da coisa sem o consentimento do devedor consistia em furto ${ }^{254}$.

Na legislação justinianéia, esse direito de alienar passa a ser inerente à natureza dos contratos de penhor, tanto que - como exaustivamente mencionado o credor mantém sua faculdade apesar do pacto de non distrahendo pignore, desde que observe a chamada tríplice denúncia.

Isso até que, com a proibição da lex commissoria por Constantino, no século IV d.C. ${ }^{255}$, passou o ius distrahendi a ser o único efeito do penhor e da hipoteca. Não encontrando comprador, no entanto, ao credor era facultado solicitar ao imperador que lhe fosse atribuída a propriedade da coisa através da impetratio dominii.

A partir de então, às atividades negociais são desenvolvidas convenções outras que, analogamente à lex commissoria, buscam a satisfação do crédito através da transferência da propriedade, sem que, no entanto, seus efeitos sejam considerados tão gravosos quanto aqueles sancionados pela proibição.

\footnotetext{
${ }^{252}$ L'ius distrahendi cit. (nt. 227 supra), p. 9.

${ }^{253}$ Cf. Gai. 2,64

${ }^{254}$ Cf., nesse sentido, Ulp. 19 ad ed., D. 10, 3, 6, 8.

${ }^{255}$ Cf. item II.3.
} 
Além do mencionado ius distrahendi, elencam as fontes numerosos exemplos de contratos orientados justamente neste sentido ${ }^{256}$, como a venda da coisa ao credor ${ }^{257}$, acordos similares à anticrese ${ }^{258}$, o pacto marciano ${ }^{259}$ e a datio in solutum ${ }^{260}$.

\section{RECONSTRUÇÃo HISTÓRICO-DOGMÁTICA POR ANALOGIA} COM O HOMÔNIMO PACTO ACESSÓRIO À COMPRA E VENDA

\subsection{FóRMULA E OBJETO}

Como oportunamente se espera demonstrar ${ }^{261}$, com base nas conclusões palingenéticas lenelianas, uma melhor análise da questão da

${ }^{256}$ Cf., nesse sentido - cf. A. BURDESE, “Lex commissoria” cit. (nt. 26 supra), pp. 119 e ss. Não é difícil, por outro lado, imaginar que muitas destas construções seriam hoje, tendo em vista a corrente interpretação da proibição do pacto comissório, igualmente sancionadas - cf. N. CIPRIANI, Patto commissorio e patto marciano - Proporzionalità e legittimità delle garanzie, Sannio Benevento, Facoltà di Economia dell’Università degli Studi del Sannio Benevento, p. 43.

${ }^{257}$ A licitude da venda da coisa dada em garantia ao credor em caso de inadimplemento era, em época clássica, princípio pacífico e podia ser concordada, condicionando-a suspensivamente ao adimplemento, seja ao momento da constituição do penhor, seja sucessivamente- cf., e.g., Tryph. 8 disp., D. 20, 5, 12 pr.; Paul. 29 ad ed., D. 13, 7, 20, 3; Paul. 6 resp., D. 20, 4, 17; Marc. sing. ad. form. hypoth., D. 20, 5, 5, 1; Marc. sing. ad. form. hypoth., D. 20, 5, 6; Paul. 3 quaest., D. 20, 5, 9 pr.; Alex. Sev., C. 8, 19, 1, 1 (de 230 d.C.); Dio. et Max., C. 8, 27, 10 (de 290 d.C.); Nov. 4, 3; P.S. $2,13,4$.

${ }^{258}$ Cf. Ulp. 4 resp., D. 13, 7, 39; Mod. 4 resp., D. 13, 7, 39. Neste último fragmento especificamente, entre credor e devedor se convém "ut creditor pignus suum in compensationem pecuniae suae cero tempore possideret". Trata-se de um pacto de natureza anticrética com base no qual o credor mantém a posse e o gozo do terreno hipotecado por um certo tempo, com o escopo de satisfazer seu crédito. Resulta do texto que um pactum de tal natureza poderia ser indicado, imprecisamente, como venda das coisas dadas em garantia aos credores - cf. H. DERNBURG, Das Pfandrecht cit. (nt. 216 supra), p. 184; A. MANIGK, Pfandrechtliche Untersuchungen, v. 1, Breslau, M\&H. Marcus, 1904, p. 134; Pignus cit. (nt. 134 supra), pp. 1271 e ss.

${ }^{259} \mathrm{Cf}$. Item II.3.1.2.

${ }^{260}$ Cf., e.g., Dio. et Max., C. 8, 13, 13 (de 293 d.C.); Dio. et Max., C. 4, 51, 4 (de 294 d.C.). L. MiTTEIS, baseando-se na análise de direitos provinciais, considera por outro lado o pacto comissório uma modalidade de datio in solutum - cf. Reichsrecht Und Volksrecht In Den Östlichen Provinzen Des Römischen Kaiserreichs, German, Nabu, 1891, p. 441. Contra, entre outros, G. BESELER, Beiträge cit. (nt. 243 supra), p. 817.

${ }^{261}$ Cf. item II.2.3. 
potestividade de exercício da lex commissoria pelo credor tem por elemento imprescindível a leitura conjunta de dois fragmentos pompeianos extraídos do livro 35 ad Sabinum.

A princípio, a estranheza causada por tal medida deve-se ao fato de apresentarem os textos objetos bastante distintos. Enquanto o primeiro, Pomp. 35 ad Sab., D. 13, 7, 6pr, cuida do pactum fiduciae, o segundo, Pomp. 35 ad Sab., D. 18, 3, 2, encontra-se sob o título "De lege commissoria" (que, como se sabe, refere-se ao instituto em matéria de compra e venda).

No entanto, em razão da já aludida escassez de fontes especificamente voltadas à análise da genericamente considerada lex commissoria pignoribus, não é raro que algumas das conclusões a ela aplicadas sejam, de fato, extraídas de passagens que tratam expressamente do regime de venda.

É o que ocorre quanto à delimitação da fórmula do instituto, para cuja abordagem se faz interessante uma peculiar passagem do mencionado Pomp. 35 ad Sab., D. 18, 3, 2.

Já em sua primeira parte, o fragmento traz aquela que seria a fórmula com a qual a lex commissoria na venda seria celebrada: "si ad diem pecunia soluta non sit ut fundus inemptus sit" - "caso o preço não tenha sido pago no termo, que o terreno seja considerado não comprado" ${ }^{262}$.

A exemplo do que entendeu quanto à in diem addictio ${ }^{263}, \mathrm{C} . \mathrm{LONGO}^{264}$ também via na construção de Pompônio sobre a lex commissoria uma fórmula a ser rigidamente seguida ("clausola di stile”), sem qualquer possibilidade de alteração formal por aqueles que a celebrassem ${ }^{265}$.

${ }^{262}$ A tradução completa também será trazida no item II.2.3.

Alternativamente, com o mesmo significado, “ si ad diem nisi pecunia soluta sit ut fundus inemptus sit" - cf. C. LONGO, Sulla "in diem addictio" e sulla "lex commissoria" nella vendita, in BIDR 31 (1921), p. 46. Sobre a constução oposta trazida em Gai. 10 ad ed. prov., D. 47, 2, 49 pr. - cf. A. BISCARDI, La Lex commissoria cit. (nt. 22 supra), p. 582.

${ }^{263}$ Cf., nesse sentido, B. B. QUEIROZ DE MORAES, O pacto de melhor comprador Configuração no direito romano ("in diem addictio") e projeções no direito atual, Madrid, Dykinson, 2010, pp. 67 e ss.

${ }^{264}$ Sulla "in diem addictio” cit. (nt. 262 supra), pp. 47- 48.

${ }^{265}$ Embora a fórmula seja fixa, para o autor, a jurisprudência clássica não a interpretou em apenas um único sentido - cf. C. LONGO, Sulla “in diem addictio” cit. (nt. 262 supra), p. 48. 
A opinião, que ganhou o apoio de autores importantes, como, e.g., A. D’ORS $^{266}$-para o qual o instituto apenas teria subsistido na prática jurídica justamente por apresentar uma única interpretação -, tem por base os seguintes argumentos:

a) Não trariam as fontes especificamente voltadas ao instituto ${ }^{267}$ qualquer outra construção que pudesse ser considerada uma fórmula.

b) Ulpiano, em Ulp. 32 ad ed., D. 18, 3, 4 pr., aplica a fórmula ao estabelecer que: "Si fundus lege commissoria venierit, hoc est, ut nisi intra certum diem pretium sit exsolutum, inemptus fieret..."268 - "Se um terreno tenha sido vendido com lex commissoria, isso é, que se dentro do termo determinado não se tenha pagado o preço, considerar-se-ia não comprado “.

c) Em Scaev. 2 resp., D. 18, 3, 6 pr., Cévola, ao interrogar sobre a lex commissoria ("De lege commissoria interrogatus...") - mediante o emprego, portanto, uma específica nomenclatura ${ }^{269}$-, responde com a expressão "fundus inemptus fore", equivalente, portanto, à mencionada "fundus inemptus sit" de Pompônio.

${ }^{266}$ No mesmo sentido - cf. F. WIEACKER, Lex commissoria (Erfüllungszwang und Widerruf im römischen Kaufrecht), Berlin, Springer, 1932, p. 64; P. BONFANTE, Corso cit. (nt. 246 supra), p. 391; G. G. ARCHI, La restituzione dei frutti nelle vendite con "in diem addictio" e con "lex commissoria", in Studi in memoria di Umberto Ratti, Milano, Giuffrè, 1934, pp. 333 e 334; F. EISELE, Beiträge cit. (nt. 243 supra), p. 137.

${ }^{267}$ Especialmente Paul. 1 decret., D. 4, 4, 38 pr.; Pomp. 9 ad Sab., D. 18, 1, 6, 1; Pomp. 35 ad Sab., D. 18, 3, 2; Ner. 5 memb., D. 18, 3, 5; Scaev. 7 dig., D. 18, 5, 10 pr.; Paul. 54 ad ed., D. 41, 4, 2; Paul. 54 ad ed., D. 41, 4, 3; Afric. 9 quaest., D. 44, 3, 6, 1.

${ }^{268}$ Contra, F. EISELE, que considerou essa explicação demasiadamente supérflua e incapaz de justificar um eventual rigor à fórmula - cf. Beiträge cit. (nt. 243 supra), p. 137. C. LoNGO rebate, dizendo que o autor deixou de considerar que, pela expressão lex commissoria, não há nenhum outro título no Digesto que pudesse corresponder a essa fórmula; o que demonstraria, por si só, a intenção dos compiladores justinianeus de estabelecer os seus limites - cf. Corso di diritto romano cit. (nt. 46 supra), p. 48.

${ }^{269}$ A questão da nomenclatura parece ter importância para C. LONGO que, aliás, afastou a possibilidade de que Ant., C. 4, 54, 1 (de 216 d.C.) e Alex. Sev., C. 4, 54, 3 pudessem tratar da lex commissoria justamente por a ela não fazerem menção expressa. Para o autor o que tem-se ali são pactos de análogos efeitos onde, embora também se tenha resultadossemlhantes àqueles atingidos pela lex commissoria quanto à restituição, caso fossem, de fato, casos de lex commissoria, seriam expressamente indicados pelo texto, como ocorre em Alex. Sev., C. 4, 54, 4 - cf. p. C. LonGo, Corso di diritto romano cit. (nt. 46 supra), p. 48. Contra, V. ARANGIO-RuIZ, La compravendita cit. (nt. 105 supra), p. 432. 
Esses argumentos de C. LONGO logo foram afastados pela communis opinio $^{270}$, que entendeu não se poder falar em rigidez da fórmula, pois, em resumo, (a) não trazem as fontes qualquer evidência de que restasse prejudicada a eficácia do negócio no caso de não observância da construção pompeiana; (b) a fixação de uma fórmula pré-concebida e de observância obrigatória seria contraditória ao reconhecimento, já no direito clássico, de significativa liberdade formal na conclusão dos contratos ${ }^{271}$.

Não se discute, porém, que, não obstante tenha sido excluída à matéria a possibilidade de que uma fórmula fixa lhe fosse aplicada, representa a construção pompeiana um importante vetor de auxílio na compreensão do instituto na venda. Inevitavelmente, portanto, coloca-se a questão de saber até que ponto seria possível estabelecer uma analogia no que diz respeito ao regime de garantias.

Para tanto, importa salientar que é a lex commissoria em matéria de garantias entendida como uma modalidade de pacto adjeto com eficácia real, pelo qual condiciona-se a definitiva transferência da coisa dada em garantia à hipótese de inadimplemento da obrigação principal,

Com base nessa definição, é possível, desde já, identificar dois importantes elementos também presentes na primeira parte da construção pompeiana, "si ad diem pecunia soluta non sit...": (a) o termo para a conclusão da obrigação principal ( “...ad diem... ”, obviamente aqui entendido como certum $^{272}$ )

${ }^{270}$ Cf. V. ARANGIO-RUIZ, La compravendita cit. (nt. 105 supra), p. 402; M. TALAMANCA, Contributi allo studio delle vendite all'asta nel mondo classico, in Atti della accademia nazionale dei Lincei, Roma, Accademia Nazionale dei Lincei, 1955, p. 219; E. LEVY, Zu den Rücktrittsvorbehalten cit. (nt. 369 supra),p. 85; R. HENLE, Die rechtliche Natur der in diem addictio beim Kaufvertrage, in Festschrift Koschaker II, Weimar, Böhlau, 1939, pp. 171 e ss.; F. PETERS, Die Rücktrittsvorbehalte des römischen Kaufrechts, Köln, Böhlau, 1973, pp. 8-9; A. BECHMAN , Der Kauf nach gemeinem Recht I (Geschichte des Kaufs im römischen Recht), Erlangen, Deichert, 1876 a 1908, p. 520; F. EISELE, Beiträge cit. (nt. 243 supra), p. 137. Contra, F. WIEACKER, Lex commissoria cit. (nt. 266 supra), p. 64; P. BONFANTE, Corso cit. (nt. 246 supra), p.391; G. G. ARCHI, La restituzione cit. (nt. 266 supra), p. 337; H. SIEG, Quellenkritische Studien cit. (nt. 266 supra), p. 33.

${ }^{271}$ Cf., entre outros, F. Peters, Die Rücktrittsvorbehalte cit. (nt. 270 supra), p. 10; B. B. QUEIROZ DE MORAES, Pacto de melhor comprador cit. (nt. 263 supra), p. 78.

${ }^{272}$ Cf., nesse sentido, V. LOJACONO, Il patto commissorio cit. (nt. 204 supra), p. 8. 
e (b) o inadimplemento pelo devedor como evento determinante ao verificar-se do negócio condicional ( “...pecunia soluta non sit...”).

Também quanto à segunda parte trazida por Pompônio, "ut fundus inemptus sit", é possível traçar um denominador comum, considerando que, tanto na venda, quanto nas garantias, a lex commissoria vincula-se a um negócio que se resolverá sob condição ${ }^{273}$.

O verificar-se do evento "inadimplemento",274, portanto, produz duas análogas consequências: enquanto na lex commissoria da venda são resolvidos os efeitos bilaterais do negócio, nas garantias, tem-se a definitiva extinção da obrigação unilateral de restituir a coisa pelo credor frustrado ${ }^{275}$.

Neste último caso, vale salientar, sendo o pacto estipulado a favor do credor, a ele cabe a faculdade de escolher entre ficar com a coisa ou manter a pretensão da obrigação principal ${ }^{276}$. No entanto, tendo uma vez decidido por qualquer delas, o exercício da outra restaria prejudicado.

De qualquer modo, certo é que, no caso das garantias reais, as poucas fontes diretas, inclusive as que determinam a proibição do instituto ${ }^{277}$, limitam-se a aplicar o termo lex commissoria sem que, no entanto, seja apresentada qualquer definição do instituto. Para V. LoJACONO, isso se justificaria pelo fato de o emprego do verbo committere, contraposto a lex $x^{278}$, já implicar, por si só, uma explicação suficientemente clara quanto a seu alcance em sentido.

Todas as observações até agora feitas tornam o estudo do objeto mais simples. Ainda que as fontes relativas à venda costumem falar em fundus ${ }^{279}$, a ausência de uma fórmula fixa a respeito, bem como de fontes que tragam qualquer

${ }^{273}$ Cf. item II.2.2.

${ }^{274}$ Por inadimplemento, no caso, entender-se-ia, a não quitação completa do débito - cf. V. LOJACONO, Il patto commissorio cit. (nt. 204 supra), p. 8. No caso em que o faltante pagamento é parcial, não teria o devedor direito à reaver os valores entregues, por extensão àquilo que se entende quanto à venda - cf., Ulp. 32 ad ed., D. 18, 3, 4, 1.

${ }^{275}$ Cf., nesse sentido, F. WIEACKER, Lex commissoria cit. (nt. 266 supra), p. 24; A. BISCARDI, Le garanzie, cit. (nt. 205 supra), p. 225; A. BURDESE, “Lex commissoria” cit. (nt. 26 supra), p. 25.

${ }^{276}$ Do mesmo modo, na venda - cf., e.g., Alex. Sev., C. 4, 54, 4 (de 222 d.C.).

${ }^{277}$ Cf. C. Th. 3, 2, 1 (de 320 d.C.) e Const., C. 8, 34, 3 (de 326 d.C).

${ }^{278}$ Cf. item II.1.1.

${ }^{279}$ Cf., e.g., Ulp. 28 ad Sab., D. 18, 3, 1; Pomp. 35 ad Sab., D. 18, 3, 2; Ulp. 32 ad ed., D. 18, 3, 4 pr.; Ulp. 32 ad ed., D. 18, 3, 4, 3; Scaev. 2 resp., D. 18, 3, 6, 1. 
tipo de vedação, torna razoável a interpretação de que o objeto da lex commissoria deva ter sempre o mesmo tratamento da garantia a que se vincula ${ }^{280}$.

\subsection{ENQUADRAMENTO DOGMÁTICO (ESTRUTURA)}

\subsubsection{ASPECTOS PRELIMINARES: O PROBLEMA DA CONDIÇÃO RESOLUTIVA NO DIREITO ROMANO}

A exemplo da moderna classificação, de um modo geral, também os manuais de direito romano ${ }^{281}$ prevêem a separação do instituto da condição em duas diversas subespécies: suspensiva e resolutiva ${ }^{282}$. Entretanto, tal divisão ${ }^{283}$,

${ }^{280}$ Nesse sentido - cf. A. BuRDESE, “Lex commissoria” cit. (nt. 26 supra), p. 24; A. BISCARDI, La lex commissoria cit. (nt. 22 supra), p. 521.

${ }^{281}$ Cf., especialmente, E. VOLTERRA, Istituzioni di diritto romano (1961), reimpr., Roma, La Sapienza, 1993, pp. 153 e ss.; V. ARANGIO-RUIZ, La compravendita cit. (nt. 105 supra), p. 132; M. TALAMANCA, Istituzioni cit. (nt. 71 supra), p. 480; A. GUARINO, Diritto privato romano, $11^{\mathrm{a}}$ ed., Napoli, Jovene, 1997, pp. 423 e ss.; A. BURDESE, Manuale di diritto privato romano, $4^{\text {a }}$ ed., Torino, UTET, 1993, pp. 200 e ss M. KASER, Das römische Privatrechts cit. (nt. 119 supra), pp. 252 e ss.; G. PUGLIESE- F. STIZIA - L. VACCA, Istituzioni di diritto romano, $2^{\mathrm{a}}$ ed., Torino, Giappichelli, 1990; A. D’ORS, Derecho privado romano, $8^{\mathrm{a}}$ ed., Pamplona, Universidade de Navarra, 1991, pp. 342 e ss.

${ }^{282}$ Sem maiores problematizações sobre seu conceito, o que não é o objetivo deste trabalho, condição costuma ser entendida como o acontecimento futuro e incerto de que se faz depender a produção ou cessação dos efeitos de um negócio jurídico. Sobre um maior aprofundamento na questão da condição resolutiva no direito romano e suas implicações no contrato de compra e venda - cf. B. B. QUEIROZ DE MORAES, Pacto de melhor comprador cit. (nt. 263 supra), pp. 76 e ss.. O tema é tratado, monograficamente, em algumas obras importantes - cf. G. G. ARCHI, Condizione nel negozio giuridico (diritto romano), in ED 8 (1961), pp. 743 e ss.; Il negozio sotto condizione sospensiva nella compilazione di Giustiniano, in Studi in onore di Emilio Betti II, Milano, Giuffrè, 1962, pp. 31 e ss.; R. ORESTANO, Condizione (diritto romano), in NNDI 3 (1959), pp. 1095 e ss.; B. AlBANESE, Gli atti negoziali nel diritto privato romano, Palermo, Università di Palermo, 1982, p. 271 e ss.; C. A. CANNATA, Atto giuridico e rapporto giuridico, in SDHI 57 (1991), pp. 335 e ss.; A. MASI, Studi sulla condizione nel diritto romano, Milano, Giuffrè, 2000, pp. 1 e ss.; Deficienza e adempimento fitizio della condizione mista in diritto classico e in diritto giustinianeo, in Studi economico-giuridici pubblicati per cura della Facoltà di Giurisprudenza della Università di Cagliari, Padova, CEDAM, 1964, pp. 103 e ss.; M. KASER, Condicio iuris und condicio tacita, in Symbolae Raphaeli Taubenschlag dedicatae, Vratislaviae, Ossolineum, 1956, pp. 421 e ss.; G. GRosso, Contributo allo studio dell'adempimento della condizione, Torino, Istituto giuridico della R. Università, 1930, pp. 3 e ss.; F. E. VASSALLI, "Dies vel condicio", in BIDR 27 (1914), pp. 192 e ss.; A. CALONGE, Em torno al problema de la retroactividad de la condición em el derecho clásico, in Studi in onore di Edoardo Volterra III, Milano, Giuffrè, 1971, pp. 143 e ss.; E. BETTI, La retroattività della "condicio" ("facti" o "iuris") in diritto giustinianeo, 
que leva em conta o momento do início de produção dos efeitos típicos do negócio condicionado, não seria propriamente romana ${ }^{284}$.

$\mathrm{Na}$ verdade, a significativa resistência por parte dos romanos para que se fosse constituída uma relação jurídica cujo prazo de existência fosse prédeterminado $^{285}$ por muito tempo constitui forte indício de que o termo "condicio" 286 fosse utilizado nas fontes ${ }^{287}$ indicando, em regra, apenas a condição suspensiva.

Tal linha de pensamento deriva da corrente sabiniana, que enquadra o negócio de compra e venda a que corresponde a lex commissoria como emptio condicionalis. Tem-se, neste caso, a mais usual forma de condição contratual

in Scrritti di diritto romano in onore di Contardo Ferrini, Milano, Hoepli, 1946, pp. 477 e ss. Para a bibliografia completa do tema - cf. . B. B. QUEIROZ DE MORAES, Pacto de melhor comprador cit. (nt. 263 supra), p. 75.

Como se bem sabe, enquanto a condição suspensiva faz depender da realização ou não de um evento futuro e incerto o início da produção dos efeitos típicos do negócio, a condição resolutiva faz depender da realização ou não de um evento futuro e incerto a cessação dos referidos efeitos. A posição adotada pelos manuais aproxima-se, portanto, daquela apresentada no direito atual, onde o sentido dado ao termo "condição" é assaz semelhante - cf C. MASSIMO BIANCA, Diritto civile III (il contratto), 2a ed., Milano, Giuffrè, 2000, pp. 537 e 538.

${ }^{283}$ Essa é apenas uma das muitas possíveis divisões aplicadas ao estudo do tema. As condições poderiam, por exemplo, classificar-se entre potestativas e negativas, conforme demandem ou não mudança no estado das coisas, ou ainda entre potestativas (simples ou meramente potestativas), casuais e mistas, conforme dependam ou não da vontade de uma das partes, da de um terceiro ou do acaso. Ambos os grupos, no entanto, diferentemente do que alegase quanto às condições suspensivas e resolutivas, foram conhecidos pelos romanos - cf., nesse sentido, a obra clássica de A. SCHEURL, Zur Lehre von den Nebenbestimmungen bei Rechtsgeschäften, Erlangen, 1871, pp. 20 e ss..

${ }^{284}$ Como lembra D'ORs, a análise do tema torna-se mais dificultosa sobretudo pelo fato de os romanos, no entanto, nunca terem chegado a elaborar uma construção unitária e abstrata do tema - cf. "In diem addictio" (contribución a la critica de la teoria de las condiciones em derecho romano), in AHDE 16 (1945), p. 203. Nesse sentido, a atividade dos pandectistas alemães do século XIX foi de fundamental importância para a formação da atual noção de "condição". Sobre este ponto e a visão do instituto durante a Idade Média - cf. D. MAFFEI, Condizione nel negozio giuridico (diritto intermedio), in ED 8 (1961), pp. 759 e ss.

285 Cf., nesse sentido, G. PUGLIESE, Istituzioni di diritto romano, $2^{\mathrm{a}}$ ed., Torino, Giappichelli,p. 188; A. GUARINO, Diritto cit. (nt. 281 supra), p. 426; M. TALAMANCA, Istituzioni cit. (nt. 71 supra), pp. 250-251; B. AlBANESE, Gli atti negoziali cit. (nt. 282 supra), p. 307.

Para V. SCIALOJA, por tal razão, ao menos no período clássico, não haveria também que se falar em propriedade resolúvel - cf. Teoria della proprietà nel diritto romano II, Roma, Sampaolesi, 1931, pp. 329 e ss. No mesmo sentido - cf. B. B. QUEIROZ DE MorAES, Pacto de melhor comprador cit. (nt. 263 supra), pp. 78.

286 Este substantivo provavelmente deriva da conjunção de cum e dicere - cf. M. TALAMANCA, Istituzioni cit. (nt. 71 supra), p. 249.

${ }^{287}$ Para a polissemia do termo nas fontes - cf. B. B. QUEIROZ DE MORAES, Pacto de melhor comprador cit. (nt. 263 supra), pp. 76-77; G. G. Archi, Il negozio sotto condizione sospensiva nella compilazione di Giustiniano, in Studi in onore di Emilio Betti II, Milano, Giuffrè, 1962, pp. 34 a 36; V. Scialoja, Negozi giuridici (1933), $5^{\text {a }}$ reimpr., Roma, Foro Italiano, 1950, p. 96. 
(condicio em sentido estrito), em que o momento inicial de produção dos efeitos do negócio dependia do evento futuro e incerto.

\section{Paulus libro quinquagensimo quarto ad edictum, D. 41, 4, 2, 3:}

Sabinus, si sic empta sit, ut, nisi pecunia|Sabino diz que se foi comprada <uma intra diem certum soluta esset, inempta res fieret, non usucapturum nisi persoluta pecunia. Sed videamus, utrum condicio sit hoc, na conventio: si conventio est, magis resolvetur, quam implebitur.

coisa>, de modo que se entendesse como
não comprada se o dinheiro não fosse pago
dentro de um certo dia, não a usucapirá, a
não ser que se tenha pago o dinheiro. Porém
vejamos se isso é uma condição ou uma
convenção: se é uma convenção, de
preferência será resolvida do que
implementada.

Dessa passagem de Paulo, que faz menção a Sabino ${ }^{288}$, chegou-se a entender ${ }^{289}$ que a compra e venda condicionada adquiria eficácia e, portanto, se aperfeiçoava, mediante o simples verificar-se do evento deduzido sob condição.

A teoria, no entanto, acabou sendo afastada pela communis opinio ${ }^{290}$. Parte desta rejeição deriva de uma construção bastante peculiar, provavelmente introduzida pelo proculeiano Nerácio ${ }^{291}$, em meados do século I d.C, e posteriormente ratificada por Juliano ${ }^{292}$.

Por meio dela, entendeu-se que ao negócio puro (sem condição) era adicionado um pacto de resolução suspensivamente condicionado, também chamado pacto de resolução sob condição suspensiva, porque, por ele, a resolução do negócio jurídico fica em suspenso até que se verifique se a condição se realizará ou não.

\footnotetext{
${ }^{288}$ No mesmo sentido, também de Paulo - cf. Paul. 54 ad ed., D. 41, 4, 2, 2.

${ }^{289}$ Cf. F. PETERS, Die Rücktrittsvorbehalte cit. (nt. 270 supra), p. 115; F. WIEACKER, Lex commissoria cit. (nt. 266 supra), p. 24.

${ }^{290}$ Cf., especialmente, F. PETERS, Die Rücktrittsvorbehalte cit. (nt. 270 supra), p. 115; G. G. ARCHI, La restituzione cit. (nt. 266 supra), p. 349; F. WIEACKER, Lex commissoria cit. (nt. 266 supra), pp. 24-25; E. LEVY, Zu den Rücktrittsvorbehalten cit. (nt. 369 supra), pp. 262-263; C. LONGO, Sulla "in diem addictio" cit. (nt. 262 supra), p. 48; . ARANGIO-RUIZ, La compravendita cit. (nt. 105 supra), pp. 418 e ss.; M. TALAMANCA, Istituzioni cit. (nt. 71 supra), pp. 251-252.

${ }^{291}$ Cf. Ner. 5 membr., D. 18, 3, 5.

${ }^{292}$ Cf., entre outros, A. D’Ors, In diem addictio cit. (nt. 284 supra), p. 195.
} 
Neste caso, o verificar-se do evento deduzido em condição, ou seja, o faltante pagamento do preço da venda, adquiria mais diretamente caráter sancionatório $^{293}$, porque a venda se resolvia como se não houvesse mais sido celebrada.

\subsubsection{ESTRUTURA DA LEX COMMISSORIA NA VENDA ${ }^{294}$}

Em sua origem, foi a lex commissoria estruturada como condição suspensiva, à luz daquele que teria sido o único sentido atribuído pelos romanos ao termo condicio em período mais antigo ${ }^{295}$. Alguns fragmentos já do período clássico $^{296}$, no entanto, induzem a entendimento diverso, indicando uma substancial mudança no tratamento do instituto.

A posição dominante hodiernamente ${ }^{297}$ é de que três foram os períodos de evolução da lex commissoria em matéria de venda: (a) primeiramente, como condição suspensiva; (b) como condição resolutiva através do chamado pacto de resolução (pactum adiectum ${ }^{298}$ ) suspensivamente condicionado, a partir de Nerácio; (c) por último, já no direito justinianeu, ter-se-ia admitido que a estrutura da cláusula dependesse das partes contratantes ${ }^{299}$.

${ }^{293}$ Cf. F. PETERS, Die Rücktrittsvorbehalte cit. (nt. 270 supra), p. 115.

294 Neste capítulo, contrariamente à regra geral que dita o presente trabalho, faz-se referência à lex commissoria na venda, ainda que se fale simplesmente de lex commissoria.

295 Cf. A. D’Ors, In diem addictio cit. (nt. 284 supra), p. 195; V. ARANGIO-RUIZ, La compravendita cit. (nt. 105 supra), p. 405.

${ }^{296}$ Cf., especialmente, Ulp. 28 ad Sab., D, 18, 3, 1; Paul. 54 ad ed., D. 41, 4, 2, 4; Ner. 5 memb., D. 18, 3, 5; Ulp. 28 ad Sab.D. 18, 1, 3; Ulp. 28 ad Sab., D. 18, 2,2 pr.

${ }^{297}$ Cf., entre outros, . D’Ors, In diem addictio cit. (nt. 284 supra), p. 40.

${ }^{298}$ Cf. F. WIEACKER, Lex commissoria cit. (nt. 266 supra), p. 22.

${ }^{299}$ No mesmo sentido, mas em relaçao à in diem addictio - cf. R. HENLE, Die rechtliche Natur cit. (nt. 270 supra), p. 234.

Congruentemente, teria que considerar interpolados aqueles textos de Ulpiano de onde tal quaestio voluntatis parece admitir-se - cf. . D’Ors, In diem addictio cit. (nt. 284 supra), p. 40. No mesmo sentido - cf. F. SENN, L'in diem addictio, in NRH 37 (1913), pp. 275 e ss.. O autor, no entanto, concebe o instituto, em sua primeira fase, como uma lex rei suae dicta que o vendedor impõe ao comprador. Esta ideia não é de todo negada pela generalidade dos autores que, no entanto, adotam uma visão mais homogênea ao conceber que a antiga lex dicta que F. SENN estendia até Juliano teria se transformado muito rapidamente em uma condição suspensiva - cf. F. WIEACKER, Lex commissoria cit. (nt. 266 supra), p. 26; H. SIEG, Quellenkritische Studien cit. (nt. 
Bastante polêmico, apesar de sequer trazer a definição do instituto, não à tôa o fragmento de Ulpiano reproduzido em Ulp. 28 ad Sab., D. 18, 3, 1 ocupa posição de destaque no correspondente título. Ele costuma ser amplamente citado pela doutrina ${ }^{300}$ ao posicionar-se sobre a estrutura da lex commissoria, que, em resumo, é entendida:

a) Como condição suspensiva, por ser esta a única conhecida pelo direito romano ${ }^{301}$

b) Como condição resolutiva pura e simples ${ }^{302}$.

c) Por vezes como condição suspensiva, por vezes como condição resolutiva - sendo esta última a regra ${ }^{303}$.

d) Como pacto de resolução suspensivamente condicionado adicionado ao negócio puro (sem condição) ${ }^{304}$.

Apesar das inúmeras possibilidades de análise, o problema a ser enfrentado é relativamente mais simples: indaga-se se a construção trazida pelas fontes entendia a lex commissoria como um negócio jurídico condicional ou se, na verdade, eram dois os negócios jurídicos a ela correspondentes, dos quais um seria condicional e outro não ${ }^{305}$.

Como ponto de partida, pela leitura do mencionado fragmento, tem-se que:

266 supra), p. 78; E. LEVY, Zu den Rücktrittsvorbehalten cit. (nt. 369 supra), p. 35; G. G. ARCHI, La restituzione cit. (nt. 266 supra), p. 325.

300 Os principais trabalhos que tratam do tema (ainda que incidentalmente) são: F. WIEACKER, Lex commissoria cit. (nt. 266 supra); E. LEVY, Zu den Rücktrittsvorbehalten cit. (nt. 369 supra); G. G. ARCHI, Condizione cit.(nt. 282 supra), p. 325; A. D’Ors, In diem addictio cit. (nt. 284 supra), p. 195; V. ARANGIO-RUIZ, La compravendita cit. (nt. 105 supra), p. 138; M. TALAMANCA, Istituzioni cit. (nt. 71 supra), pp. 251-252; G. G. ARCHI, La restituzione cit. (nt. 266 supra), p. 337.

${ }^{301}$ P. F. GIRARD, Manuel élémentaire cit. (nt. 26 supra), p. 552; R. MONNIER, Manuel elémentaire cit. (nt. 54 supra), p. 216.

${ }^{302}$ Cf. B. WINDSCHEID, Lehrbuch des Pandeltenrechts I e II, 1900, trad. it. de C. Fadda e P. E. Bensa, Diritto delle Pandette I (1902) e II (1904), reimpr., Torino, UTET, 1925, pp. 346-347.

${ }^{303}$ Cf. G. ACUTIS, De lege commissoria, Torino, Subalpina, 1901, p. 07.

${ }^{304}$ Cf.,especialmente, M. TAlamancA, Istituzioni cit. (nt. 71 supra), pp. 250-251. Para o autor, já no período clássico se revela embrionalmente algumas distinções posteriormente desenvolvidas pela doutrina medieval e moderna. No mesmo sentido - cf. G. G. ARCHI, Il negozio cit. (nt. 282 supra), pp. 35 e 36. Contra, R. ORESTANO, para o qual apenas no período justinianeu é que foi inserida a cláusula resolutiva diretamente no negócio principal - cf. Condizione cit. (nt. 282 supra), p. 1096,. Sobre a visão do instituto na Idade Moderna - cf. M. MAFFEI, Condizione nel negozio giuridico (diritto intermedio), in ED 8 (1961), pp. 759 e ss.

${ }^{305}$ Sobre a questão - cf. V. SCIALOJA Negozi cit. (nt. 287 supra), p. 101. 
Ulpiano libro vincensimo octavo ad Sabinum, D. 18, 3, 1:

Si fundus ${ }^{306}$ commissoria lege venierit, $\mid$ Se um terreno foi vendido com lex magis est ${ }^{307}$, ut sub condicione resolvi ${ }^{308}$ commissoria, é mais correto <entender> que emptio quam sub condicione contrahi a compra se resolva sob condição ao invés videatur. sido celebrada sob condição.

No fragmento, diz Ulpiano que, tendo um terreno sido vendido com lex commissoria ("Si fundus commissoria lege venierit..."), deve-se entender que essa compra e venda se desfaça sob condição ("...ut sub condicione resolvi emptio...") e não que se contraia sob condição ( “...quam sub condicione contrahi videatur”). O texto, portanto, condiciona a irradiação dos efeitos do negócio ao momento de sua conclusão.

É de se notar a utilização do verbo contrahere ${ }^{309}$, em contraposição à bastante polêmica expressão "sub condicione resolvi”,também trazida em dois outros importantes fragmentos extraídos da mesma obra do jurisconsulto ${ }^{310}$ : Ulp. 28 ad Sab.D. 18, 1, 3, que cuida do pactum displicentiae, e Ulp. 28 ad Sab., D. 18, 2, 2 pr., sobre a in diem addictio $^{311}$.

${ }^{306}$ Cf. item II.2.3.

307 Para A. SACCHI, com a construção “magis est” não é possível afirmar qualquer presunção em caso de dúvida sobre a intenção das partes - cf. Sul patto commissorio cit. (nt. 90 supra), p. 11.

${ }^{308}$ Sobre o termo - cf. P. CERAMI, Risoluzione del contratto (dir. rom.), in Enc. Dir. 40, Milano, 1989, pp. 1277 e ss; R. SANTORO, Su D. 46, 3, 80 (Pom. 4 'ad Quintum Mucium'), Estratto dagli Annali del Seminario Giuridico dellÚniversita degli Studi di Palermo (AUPA), v. LV, Torino, Giappichelli, 2012.

${ }^{309}$ Sobre o alcance de contrahere - cf. P. BONFANTE, Corso cit. (nt. 246 supra), p 34; ; Id., Sulla genesi e l'evoluzione del 'contractus`, in RIL. 40 (1907), Torino, 1921, pp. 107 e ss.; E. BETTI, Sul valore dogmatico della categoria 'contrahere'in giuristi proculiani e sabiniani, in BIDR. 28 (1915), pp. 3 e ss.; G. GROSso, Il sistema romano dei contratti, $3^{\text {a }}$ ed., Torino, Giappichelli, 1963, pp. 29 e ss.; G. GROsso, 'Contratto (diritto romano)', in ED. 9 (1961), pp. 750 e ss.; B. BIONDI, Contratto e stipulatio (corso di lezioni), Milano, Giuffrè, 1953, pp. 195 e ss.; G. MELILlo, Contrahere, pacisci, transigere - contributi allo studio del negozio bilaterale romano, Napoli, Liguori, pp. 125 e ss; R. FIORI, 'Contrahere' $e$ 'solvere obligationem' in Q. Mucio Scevola, pp. 1956 e ss.

${ }^{310}$ D'ORS acentua a incorreção de O. LENEL (Ulp. Pal. 2707 a 2711), que intercala os fragmentos sobre a lex commissoria, o pactum displicentiae e a in diem addictio, ao invés de distribuí-los de forma sucessiva - In diem addictio cit. (nt. 284 supra), p. 251.

${ }^{311}$ De fato, a forma verbal se repete nos já mencionados fragmentos Ulp. 28 ad Sab., D. 18, 1, 3 ("Si res ita distracta sit, ut si displicuisset inempta esset, constat non esse sub condicione 
Esses dois últimos fragmentos, aliás, têm um ponto em comum que não se verifica quanto à lex commissoria: neles são trazidas hipóteses em que uma compra - expressamente definida como pura - se resolve sob condição ("pura emptio, quam sub condicione resolvitur"). Ou seja, cuidam de uma pura emptio $^{312}$ à qual se acrescia um pacto de resolução suspensivamente condicionado $^{313}$.

distractam, sed resolvi emptionem sub condicione" = Se uma coisa foi vendida com o pacto que, se não agradasse, se devesse considerar não comprada, é certo que a coisa não é vendida sob condição, mas que a compra e venda se resolve após o verificar-se da condição), e Ulp. 28 ad Sab. D. 18, 2, 2 pr. ("Quotiens fundus in diem addicitur, utrum pura emptio est, sed sub condicione resolvitur, na vero condicionalis sit magis emptio, quaestionis est. Et mihi videtur verius interesse, quid actum sit: nam si quidem hoc actum est, ut meliore allata condicione discedatur, erit pura emptio, quae sub condicione resolvitur: sin autem hoc actum est, ut perficiatur emptio, nisi melhor condicio offeratur, erit emptio condicionalis" = "Todas as vezes que se faz a in diem addictio de um terreno, é perguntado se a compra é pura, mas é resolvida sob condição, ou se, na verdade, a compra é condicional. E me parece verdadeiramente importar aquilo que foi estabelecido, pois se, em realidade, foi estabelecido que seja desfeita quando realizada uma melhor oferta, será a compra pura, que se resolve sob condição; mas se foi estabelecido que a compra se aperfeiçoa a não ser que uma melhor condição seja oferecida, a compra será condicional").

Ao analisar o fragmento Ulp. 28 ad Sab., D. 18, 2, 2 pr., B.B. QUEIROZ DE MORAES, a quem creditamos esta última tradução, elucida, com base na opinião manifestada pela doutrina tradicional, que nos fragmento se contrapõem as hipóteses de uma "emptio condicionalis", onde a eficácia do negócio dependia do evento futuro e incerto, a uma "emptio pura", à qual se acrescia um pacto de resolução suspensivamente condicionado. Em ambas as hipóteses, porém, segundo o autor, os efeitos seriam os mesmos de uma condição resolutiva- cf. Pacto de melhor comprador cit. (nt. 263 supra), pp. 78-79. No mesmo sentido - cf. M. TALAMANCA, Istituzioni cit. (nt. 71 supra), p. 480.

Sobre o tema, cf. G. Grosso, Il sistema romano dei contratti, $3^{\text {a }}$ ed., Torino, Giappichelli, 1963, pp. 29 e ss.; B. Biondi, Contratto e stipulatio (corso di lezioni), Milano, Giuffrè, 1953, pp. 195 e ss.; G. Melillo, Contrahere cit. (nt. 309 supra), pp. 125 e ss. Para uma visão sistemática dos três fragmentos - cf. V. ARANGIO-RUIZ, La compravendita cit. (nt. 105 supra), pp. 411 e ss.; F. PETERS, Die Rücktrittsvorbehalte cit. (nt. 270 supra), pp. 100 e ss.; B. B. QUEIROZ DE MORAES, Pacto de melhor comprador cit. (nt. 263 supra), pp. 76 e ss.

R. HENLE, contudo, discute o método equivocado de se estudar, conjuntamente, as figuras da lex commissoria, da in diem addictio e do pactum displicentiae, que não seriam de todo análogas. $\mathrm{O}$ autor as diferencia do seguinte modo: a lex commissoria, que não se referia aos efeitos do contrato, mas a seu incumprimento, seria um "Bebenabrede mit Verfall-Klausel"; o pactum displicentiae seria um "Rücktrittsvorbehalt", a in diem addictio, uma "gemischt-potestative Bedingung”- cf. Die rechtliche Natur cit. (nt. 270 supra), p. 234.

312 Além de Ulpiano, o único jurista que emprega a expressão emptio pura é Marcelo - cf. referência feita pelo próprio Ulpiano em Ulp. 28 ad Sab., D. 18, 2, 4, 3.

${ }^{313}$ Cf., nesse sentido, B. B. QUeIROZ DE MORAES, Pacto de melhor comprador cit. (nt. 263 supra), p. 79 . 
No entanto, essa construção, que provavelmente remete ao final do período clássico ${ }^{314}$, acaba por ter uma importância muito mais terminológica do que efetivamente prática $^{315}$. Isso porque, quanto aos seus efeitos, não há no que diferenciá-la de uma condição resolutiva propriamente dita.

Acredita-se ${ }^{316}$ que as semelhanças dessa nova estrutura, em que são previstos dois negócios (um condicional e outro não condicional), com aquela da condição suspensiva, da qual certamente derivou ${ }^{317}$, tenham sida a razão pela qual o termo condicio passou a ser utilizado para tratar de ambas as situações, indistintamente - a ponto, inclusive, de ter também sido empregada como sinônimo de pactum adiectum ou lex dicta ${ }^{318}$.

Por isso, o fato de nos fragmentos relativos ao pactum displicentiae e à in diem addictio ter sido utilizada a expressão "pura emptio" não deslegitima a hipótese de que, também nesses casos, o negócio fosse condicionado.

É o que ocorre igualmente no caso da lex commissoria, na qual, contudo, chegou-se a entender ${ }^{319}$ que a condição se referiria à própria venda, por não haver em Ulp. 28 ad Sab., D. 18, 3, 1 qualquer indicação de que a condição se refira a um pacto acessório.

314 Cf. V. ARANGIO-RuIZ, La compravendita cit. (nt. 105 supra), pp. 418 e ss.; M. TALAmAnCA, Istituzioni cit. (nt. 71 supra), pp. 251-252; B. B. QUEIROZ DE MORAES, Pacto de melhor comprador cit. (nt. 263 supra), p. 78.

${ }^{315}$ Cf. M. TALAMANCA, Istituzioni cit. (nt. 71 supra), p. 252; B. B. QUEIROZ DE MORAES, Pacto de melhor comprador cit. (nt. 263 supra), p. 78. Contra, B. AlBANESE, Gli atti negoziali cit. (nt. 282 supra), p. 327.

${ }^{316}$ Cf. V. ARANGIO-RUIZ, La compravendita cit. (nt. 105 supra), p. 405.

${ }^{317}$ Especialmente nas obrigações das quais derivavam actiones bonae fidei - cf. M. KASER, Das römische Privatchet I cit.(nt. 117 supra), p. 257.

${ }^{318}$ Cf. G. G. ARCHI, La restituzione cit. (nt. 266 supra), p. 34. O conceito técnico, porém, continuou sendo reservado à condição suspensiva - cf. G. G. ARCHI, La restituzione cit. (nt. 266 supra), p. 35.

${ }^{319}$ Cf., nesse sentido, B. B. QUEIROZ DE MORAES, que fundamenta sua opinião em Bas. 19, 3,1 , onde também não se encontraria qualquer indicação de que a condição tenha sido constituída por intermédio de um pactum - cf. B. B. QUEIROZ DE MORAES, Pacto de melhor comprador cit. (nt. 263 supra), p. 80. O texto das Basílicas, presente apenas na edição G. E. Heimbach - K. W. E. Heimbach, Basilicorum II, p. 273, onde também se encontra sua tradução para o latim, é o seguinte:

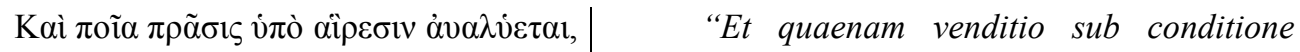

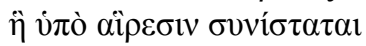
resolvatur, vel sub conditione contrahatur”.

O texto, como se percebe, é baseado em Ulp. 28 ad Sab., D. 18, 3, 1 e traz a o equivalente

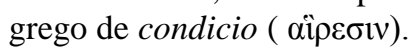


Na verdade, a leitura do fragmento traz justamente o sentido oposto: é a presença da lex commissoria na venda que faz com que ela se resolva sob condição. Logo, a exemplo do que ocorre com os análogos pactos também em matéria de venda, estar-se-ia diante de uma hipótese em que o negócio puro tem seus efeitos condicionados a um pactum.

Semelhante construção, aliás, foi utilizada em um fragmento de Paulo que trata da in diem addictio. Ali, novamente se contrapõe o verbo contrahere à expressão "sub condicione resolvi", sem que se faça qualquer menção a uma eventual emptio pura:

\section{Paulus libro quinquagensimo quarto ad edictum, D. 41, 4, 2, 4:}

\begin{tabular}{|c|c|}
\hline $\begin{array}{l}\text { Si in diem addictio facta sit, id est nisi si } \\
\text { quis meliorem condicionem attulerit, } \\
\text { perfectam esse emptionem et fructus } \\
\text { emptoris effici et usucapionem procedere } \\
\text { iulianus putabat: alii et hanc sub } \\
\text { condicione esse contractam, ille non } \\
\text { contrahi, sed resolvi dicebat, quae } \\
\text { sententia vera est. }\end{array}$ & $\begin{array}{l}\text { Se foi feita a in diem addictio, isto é, a não } \\
\text { ser que alguém tenha oferecido uma melhor } \\
\text { condição, Juliano julgava que a compra era } \\
\text { perfeita, que os frutos aproveitavam ao } \\
\text { comprador e que se contava o <prazo do> } \\
\text { usucapião. Para outros <juristas>, que } \\
\text { também era contratada sob condição. <E } \\
\text { ele> dizia que ela não era celebrada <sob } \\
\text { condição>, mas sim que se desfazia <sob } \\
\text { condição>. E esta opinião é a correta } 320\end{array}$ \\
\hline
\end{tabular}

O fragmento é essencial para a análise da posição de Paulo diante da concepção de Juliano quanto à construção da condição resolutiva. Nele, o jurisconsulto afirma que, contraído o negócio com in diem addictio ( “...in diem addictio facta...”), a venda já produziria todos os seus efeitos típicos (“...perfectam esse emptionem et fructus emptoris effici et usucapionem procedere...”), caso não tenha sido oferecida uma condição mais interessante ao vendedor ( “...id est nisi si quis meliorem condicionem attulerit... ") ${ }^{321}$.

${ }^{320}$ Traduzido por B. B. QUEIROZ DE MORAES, Pacto de melhor comprador cit. (nt. 263 supra), p. 81.

${ }^{321}$ Sobre a concepção do adjetivo perfectus nas fontes - cf. B. B. QUEIROZ DE MORAES, Pacto de melhor comprador cit. (nt. 263 supra), p. 81, que lembra que, no fragmento em questão, perfecta não é sinônimo de pura, ou seja, incondicionada sujeita a um pacto resolutivo expresso 
É curioso como, ao fim do texto, Paulo contrapõe a opinião de Juliano ( “...iulianus putabat...”), com a qual diz concordar ( “...vera est ...”), à de outros juristas (“...alii...”), que, contrariamente, entendiam a venda como tendo sido celebrada sob condição ( “...sub condicione esse contractam...”).

Com isso, entende-se ${ }^{322}$ que Juliano tivesse concebido uma condição resolutiva propriamente dita. Dada a semelhança de construção com o mencionado fragmento, cuja principal terminologia sobre o tema é praticamente a mesma de Ulp. 28 ad Sab., D. 18, 3, 1, nada obstaria que o mesmo entendimento pudesse ser estendido à lex commissoria.

Antes de Juliano, porém, já Pompônio parecia ${ }^{323}$ atribuir a estrutura da condição resolutiva à lex commissoria. Na parte incial de Pomp. 35 ad Sab., D. $18,3,2^{324}$ se lê: "Cum venditor fundi in lege ita caverit: 'si ad diem pecunia soluta non sit, ut fundus inemptus sit'” (= "Quando o vendedor de um terreno, em uma cláusula, assim tiver expressado: 'caso o preço não tenha sido pago no termo, que o terreno seja considerado não comprado'”').

O jurista estabelece que, por meio da lex commissoria, os efeitos da venda se resolverão em caso de inadimplemento, se assim quiser o vendedor. É possível ver claramente que, em Pompônio, a condição se dá através de uma lex dicta - entendimento que apenas corrobora o pensamento atribuído a Juliano (ainda que a ele tenha sido anterior) sobre a previsão, já em período clássico, do pacto de resolução sob condição suspensiva.

É essa a ideia, aliás, presente no fragmento de Nerácio sobre o tema:

suspensivamente condicionado. Contra - cf. C. LONGO, Sulla "in diem addictio" cit. (nt. 262 supra), p. 43.

322 Cf. E. LeVy, Zu den Rücktrittsvorbehalten cit. (nt. 369 supra), pp. 119-120; B. B. QUEIROZ DE MORAES, Pacto de melhor comprador cit. (nt. 263 supra), p. 82.

${ }^{323} \mathrm{Cf}$., nesse sentido, R. ZIMMERMAN, The law of obligations - roman foundations of the civilian tradition, London, Oxford University, 1996, p. 738; M. TALAMANCA, Recensão a F. Peters, Die Rückstrittsvorbehalte des römischen Kaufrechts, in IURA, 24 (1973), p. 393.

${ }^{324}$ Reproduzido acima - cf. item II.2.3. 
Neratius libro quinto membranarum, D. 18, 3, 5:

Lege fundo vendito dicta, ut, si intra certum tempus pretium solutum non sit, res inempta sit, de fructibus, quos interim emptor percepisset, hoc agi intellegendum est, ut emptor interim eos sibi suo quoque iure perciperet: sed si fundus revenisset, aristo existimabat venditori de his iudicium in emptorem dandum esse, quia nihil penes eum residere oporteret ex re, in qua fidem fefellisset.
Vendido um terreno com uma lex dicta ${ }^{325}$ <sob a condição de> que, se dentro de certo tempo não se tenha pagado o preço, se considerará não comprada a coisa, com relação aos frutos, que entretanto tivesse percebido o comprador, deve-se entender que se tratou disso, que o comprador os percebesse entretanto para si e por seu próprio direito: porém se tivesse devolvido o terreno, entendia Aristão, que ao vendedor se deve dar uma ação em relação a eles <, os frutos, > contra o comprador, porque não deve ficar em seu poder nada por força da coisa em relação a qual tivesse faltado boa-fé.

No mesmo sentido apresentado por Pompônio, o fragmento de Nerácio, em sua parte inicial, traz a hipótese de que seja tido por não comprado ("...res inempta sit...") o terreno vendido com a lex commissoria ("Lege fundo vendito dicta...”), em caso de inadimplemento ( “...si intra certum tempus pretium solutum non sit...").

Também aqui se admitiria, antes de Pompônio e de Juliano, que à venda fosse acrescentado um pacto de resolução suspensivamente condicionado $^{326}$. Logo, a importância do fragmento de Nerácio também é de ter se apresentado como pioneiro ao demonstrar que, desde o século I d.C., era conhecida a construção da compra e venda como pura, mas sujeita ao mencionado pacto resolutivo suspensivamente condicionado.

325 “Pacto expresado" - - cf. I. L. GARCIA DEL CORRAL, Cuerpo del derecho cit. (nt. 40 supra), p. 912.

${ }^{326}$ Cf. F. WIEACKER, Lex commissoria cit. (nt. 266 supra), pp. 24-25, E. LEVY, Zu den Rücktrittsvorbehalten cit. (nt. 369 supra), p. 121; F. SENN, L'in diem addictio cit. (nt. 299 supra), p. 294, H. Sieg, Quellenkritische Studien cit. (nt. 266 supra), p. 11; G. G. ARCHI, La restituzione cit. (nt. 266 supra), p. 349; C. LONGO, Sulla “in diem addictio” cit. (nt. 262 supra), p. 48; . ARANGIO-RUIZ, La compravendita cit. (nt. 105 supra), pp. 418 e ss. 
No século seguinte, Juliano passou a estender os mesmos efeitos ao pactum displicentiae e à in diem addictio, fazendo com que muitos jurisconsultos se afastassem da posição sabiniana ${ }^{327}$. A adesão foi tamanha que C. LoNGO ${ }^{328}$, exageradamente, chegou a afirmar que a posição de Juliano foi adotada por toda a jurisprudência.

De qualquer modo, a divergência entre os jurisconsultos romanos quanto à construção da lex commissoria não deixa de se refletir em seus efeitos.

Estruturada como condição resolutiva, o comprador se torna desde logo proprietário, produzindo o negócio seus efeitos típicos. O liame entre as partes, no entanto, sujeita-se a um evento futuro e incerto (no caso, o adimplemento da obrigação), em função do qual o negócio pode ser desfeito.

Assim, o comprador, sob condição suspensiva, se entrava na posse da coisa, não poderia se valer do tempus ad usucapionem para dela se tornar proprietário, não percebia os frutos e não suportava os riscos.

Por outro lado, o mesmo comprador, sob condição resolutiva, começaria a usucapir pro emptore, fazia seus os frutos e, em virtude da regra do periculum rei venditae, poderia ser tido a pagar o preço no caso de perecimento da coisa.

No entanto, inversamente, ter-se-ia uma situação bastante desfavorável ao vendedor, caso, e.g., desfeito o negócio por inadimplemento do comprador, ficasse ele desprovido da restituição frutos percebidos pendente condicione. Daí ter-se admitido, já no século III d.C., a retroatividade da condição resolutiva, a fim de que pudessem ser reequilibradas as posições das partes ${ }^{329}$.

${ }^{327}$ É o que ocorre, e.g., com Paulo - cf., especialmente, Paul. 54 ad ed., D. 41, 4, 2, 4. Contra, A. D’Ors, In diem addictio cit. (nt. 284 supra), p. 236.

${ }^{328}$ Contra, entre outros, E. LEVY, Zu den Rücktrittsvorbehalten cit. (nt. 369 supra), p. 262; A. D’Ors, In diem addictio cit. (nt. 284 supra), p. 236.

${ }^{329}$ Cf. G. G. ARCHI, La restituzione cit. (nt. 266 supra), pp; 15 e ss.; ARANGIO-RUIZ, La compravendita cit. (nt. 105 supra), pp. 414 e ss.

Quanto à condição suspensiva, de uma forma geral, sustenta-se que seu implemento não produzia efeitos retroativos no período clássico (em especial nos negócios condicionados que implicavam na transferência da propriedade), enquanto o direito justinianeu teria aceitado a retroatividade como regra geral - cf., especialmente, A. CALONGE, En torno al problema cit. (nt. 282 supra), pp. 143 e ss.; E. BETTI, La retroattività cit. (nt. 282 supra), pp. 477 e ss.; R. ORESTANO, Condizione (nt. 282 supra), pp. 1095 e ss. Contra - cf. A. MASI, Studi sulla condizione cit. (nt. 282 supra), p. 158. 
De modo geral, nos casos em que a condição resolutiva é aposta ao ato translativo de propriedade ou de direito real sobre coisa alheia, discute-se se, realizada a condição, o alienante recupera ipso iure o domínio, podendo reclamálo do adquirente ou de terceiro mediante reivindicatio (e a resolução, nesse caso, se diz real) ${ }^{330}$, ou, ao contrário, apenas passa a ter o direito pessoal de exigir do adquirente - e só dele - a devolução da coisa (resolução obrigatória) ${ }^{331}$.

A opinião dominante ${ }^{332}$ é no sentido de que, no direito anterior a Justiniano, ocorria a resolução obrigatória, embora não negue que, em limites bastante estreitos, pudesse admitir a resolução real, por sua vez, largamente aplicada no direito justinianeu.

Reforçam de maneira irrefutável esse entendimento dois fragmentos um do período clássico e outro, do pós-classico - que tratam de modo oposto a questão, referindo-se, inclusive, a uma mesma constituição imperial. São eles F.V. 283 e Diocl. et Max., C. 8, 54, 2 (de 286 d.C.).

Em F.V. 283, tem-se que, entregue em doação a propriedade de praedia stipendiariorum sob a condição de que retornasse ao patrimônio do doador após o evento da morte do donatário, não poderia o negócio considerar-se válido.

Retratando a provável posição de grande parte dos jurisconsultos $\operatorname{clássicos}^{333}$, isso se justificaria pelo fato de uma propriedade não poder ser transferida ad tempus ("Si praediorum stipendiariorum proprietatem dono dedisti ita, ut post mortem eius qui accepit ad te rediret, donatio inrita est, cum ad tempus proprietas transferri nequiuerit").

Em Diocl. et Max., C. 8, 54, 2 (de 286 d.C.), por outro lado, a mesma constituição é interpretada no sentido de validar a hipótese supramencionada, com a manutenção da cláusula, de modo que o negócio possa sujeitar-se a um prazo

${ }^{330}$ Neste caso, há aquilo que tecnicamente se chama de propriedade resolúvel $-\mathrm{cf}$. P. BONFANTE, Corso cit. (nt. 246 supra), pp. 374-376; E. LEVY, Zu den Rücktrittsvorbehalten cit. (nt. 369 supra), pp. 226 e ss..; V. SCIALOJA Negozi cit. (nt. 287 supra), pp. 176-177.

331 Nesse sentido, cf. J. C. MoreIRA Alves, Direito Romano cit. (nt. 232 supra), p. 171.

332 A propósito, v. V. SCIALOJA Negozi cit. (nt. 287 supra), pp. 176 e ss.

${ }^{333}$ Cf. F. PETERS, Die Rücktrittsvorbehalte cit. (nt. 270 supra), p. 115; F. WIEACKER, Lex commissoria cit. (nt. 266 supra), p. 48. 
certo ou incerto ("...donatio valet, cum etiam ad tempus certum vel incertum ea fieri potest, lege scilicet quae ei imposita est conservanda").

Como as duas passagens, evidentemente contraditórias ${ }^{334}$, refletiriam a mesma constituição imperial, pode-se inferir, com absoluta segurança, que a segunda tenha sido interpolada ${ }^{335}$. Enquanto na primeira é enfatizado o caráter perpétuo da propriedade, na segunda, este é mitigado, com a admissão da propriedade resolúvel.

A nova posição de direito justinianeu é trazida, inclusivem, em dois fragmentos especificamente direcionados à lex commissoria. São eles:

a) Scaev. 7 dig., D. 18, 3, 8: Cévola relata a situação de uma mulher que recebeu parcialmente uma quantia a título de arras pela venda de terrenos, tendo sido acordado para um momento posterior o pagamento do restante ("Mulier fundos Gaio Seio vendidit et acceptis arrae nomine certis pecuniis statuta sunt tempora solutioni reliquae pecuniae... "). No caso de não pagamento, o comprador Caio Seio perderia as arras e o negócio considerar-se-ia como não celebrado ("...quibus si non paruisset emptor, pactus est, ut arram perderet et inemptae villae essent...”). No termo acordado, porém, o pagamento não consegue ser efetuado exclusivamente em razão da ausência da vendedora ( "...die statuto emptor testatus est se pecuniam omnem reliquam paratum fuisse exsolvere (et sacculum cum pecunia signatorum signis obsignavit), defuisse autem venditricem..."). Apesar de o inadimplemento ter se verificado por motivo que não lhe pudesse ser imputado, o comprador foi citado no dia seguinte para que sofresse as consequências do não pagamento ( “...posteriore autem die nomine fisci testato conventum emptorem, ne ante mulieri pecuniam exsolveret, quam fisco satisfaceret. ...”). O jurista coloca a questão de ser ou não possível uma rei vindicatio por parte da vendedora ("...Quaesitum est, an fundi non sint in ea causa, ut a venditrice vindicari debeant ex conventione venditoris...") e responde, por fim, que não poderia o comprador sofrer os efeitos da lex commissoria

${ }^{334}$ Sobre elas - cf. A. MASI, Studi sulla condizione cit. (nt. 282 supra), p. 147.

${ }^{335}$ Cf. F. WIEACKER, Lex commissoria cit. (nt. 266 supra), pp. 66 e ss.No mesmo sentido cf. B. B. QUEIROZ DE MORAES, Pacto de melhor comprador cit. (nt. 263 supra), p. 104. 
(“...Respondit secundum ea quae proponerentur non commisisse in legem venditionis emptorem").

Ao analisar o fragmento, E. BETTI ${ }^{336}$ entende que, a propósito dos efeitos retroativos a que se vinculava o negócio, ter-se-ia uma resolução real, tendo sido mencionada a vindicatio a propósito da coisa já transferida resolutivamente - à propriedade alheia.

Ainda que a medida não seja possível, por ter o inadimplemento ocorrido por força de um fato imputado exclusivamente à vendedora, é interessante a evidente adoção do pensamento justinianeu ali trazida.

b) Alex. Sev., C. 4, 54, 4 (de 222 d.C.): Não se pode utilizar a lex commissoria ("Commissoriae venditionis legem exercere non potest...") se, verificado o termo, não se exige a coisa por rei vindicatio ("...qui post praestitutum pretii solvendi diem non vindicationem rei eligere..."), por preferir receber o preço ( “...sed usurarum pretii petitionem sequi maluit...”).

No fragmento, portanto, afirma-se que não pode se arrepender o vendedor que, podendo ser beneficiado pelos efeitos da lex commissoria na resolução do negócio, preferiu não fazê-lo. Uma vez mais, verificada o evento negativo do faltante pagamento, teria o vendedor a seu dispor uma ação real (rei vindicatio) para recuperar o domínio da coisa vendida. Também este mecanismo é acorde à concepção justinianéia, com o agir retroativo da condição e a consequente extinção automática do domínio do adquirente ${ }^{337}$.

Por fim, como mencionado alhures, também a titularidade dos frutos percebidos sofre influencias pela forma como a lex commissoria é construída ${ }^{338}$.

Concebido o instituto como condição suspensiva, os frutos percebidos pendente condicione não podem, em princípio, pertencer ao comprador, que ainda não é proprietário da coisa. Inversamente, sendo concebido como condição resolutiva, os frutos são normalmente atribuídos ao comprador, excedo se

\footnotetext{
${ }^{336}$ La retroattività cit. (nt. 282 supra), pp. 498-499.

${ }^{337}$ No mesmo sentido - cf. Ant., C. 4, 54, 1 (de 216 d.C.).

${ }^{338}$ Cf. A. CALONGE, En torno al problema cit. (nt. 282 supra), p. 145.
} 
resolvido o negócio por força do inadimplemento, dada a retroatividada dos efeitos da condição ${ }^{339}$.

É o que se verifica no mencionado Ner. 5 memb., D. $18,3,5^{340}$, em que Nerácio entende ser direito do comprador perceber os frutos, a menos que desfeito o negócio pelo não verificar-se do evento. Neste caso, os frutos deveriam ser restituídos por força do princípio da boa-fé.

Essa regra que determina a restituição dos frutos, no entanto, não é justinianéia. Já em F.V. 14, que, também cuida da lex commissoria, é expressamente previsto que os frutos percebidos antes do desfazimento da venda devam ser devolvidos na ação de venda ("lege venditionis inempt praedio facto fructus interea perceptos iudicio venditi restitui placuit...") ${ }^{341}$.

\subsubsection{CONCLUSÕES EXTENSÍveIS À LEX COMmisSORIA} PIGNORIBUS

Em que se considerem as peculiaridades da lex commissoria em matéria de venda ${ }^{342}$ e da lex commissoria em matéria de garantias reais, não seria absurdo, no que diz respeito à estrutura, estabelecer uma analogia substancial entre os dois pactos, a princípio pertencentes a dois tão diferentes campos da prática contratual.

À primeira vista, parece ser possível encontrar um denominador comum no fato de que ambas importariam consequências bastante análogas no

${ }^{339}$ Nesse sentido - cf F. WIEACKER, Lex commissoria cit. (nt. 266 supra), pp. 66 e ss.; F. PETERS, Die Rücktrittsvorbehalte cit. (nt. 270 supra), p. 232. Nada obstaria, no entanto, que soluções diversas fossem adotadas, inclusive pela mera vontade das partes - cf. E. LEVY, Zu den Rücktrittsvorbehalten cit. (nt. 369 supra), p. 262.

${ }^{340}$ A tradução completa é apresentada acima, neste mesmo item.

${ }^{341}$ No mesmo sentido, quanto à in diem addictio, Ulp. 32 ad ed., D. 18, 2, 16. Para uma análise mais detalhada do fragmento - cf. B. B. QUEIROZ DE MORAES, Pacto de melhor comprador cit. (nt. 263 supra), pp. 113-114.

${ }^{342}$ Sobre a lex commissoria na venda - cf., especialmente, F. WIEACKER, Lex commissoria cit. (nt. 266 supra), p. 62, E. LEVY, Zu den Rücktrittsvorbehalten cit. (nt. 369 supra), p. 260. 
que diz respeito à eficácia do negócio a que são acessórias, no caso de faltante adimplemento em uma determinada data.

Assim, enquanto na lex commissoria da venda resolver-se-iam os efeitos bilaterais do negócio caso comprador não tivevesse pago o preço dentro de um dado termo, nas garantias, com a lex commissoria ter-se-ia a definitiva extinção da obrigação unilateral de restituir a coisa, caso não tenha o devedor efetuado a quitação de seu débito dentro do termo acordado ${ }^{343}$.

Como visto no presente capítulo, a partir do século II, com Juliano ${ }^{344}$, passou-se a entender a cláusula comissória anexa à compra e venda como pacto de resolução condicionado adjeto à conclusão de um contrato incondicionado (puro).

Essa ideia se contraporia à construção jurisprudencial mais antiga, para a qual a lex commissoria se apresenta sob forma de condicionamento suspensivo - até então a única conhecida pelo sistema romano - da eficácia da compra e venda. Em ambos os casos, no entanto, a condição resulta constituída pelo pagamento do preço, por parte do comprador, dentro de um dia determinado ${ }^{345}$.

Não é difícil deduzir a razão de seu emprego ${ }^{346}$ : superado o estado da primitiva venda real, com a separação entre o negócio com eficácia obrigatória e seu sucessivo adimplemento, é natural que se tivesse sentido a necessidade de tutelar o vendedor de uma eventual insolvência do comprador.

Não é possível, contudo, dizer se, em um estado intermediário anterior ao surgimento do contrato consensual de compra e venda ${ }^{347}$, tenha a lex

${ }^{343}$ Com acostamento um pouco empírico N. LEONHARD fala de uma diversidade de objeto do prazo determinada pelo pacto commissorio: na venda se teria "Verfall des Geschäftes", nas garantias, "Verfall des Pfands" - cf. Commissoria lex, in Pauly-Wissowa R.E., 4, 1 (1900), c. 769.

344 Antes, porém, já Nerácio e Pompônio traziam soluções semelhantes - cf. Ner. 5 memb., D. 18, 3, 5, Pomp. 35 ad Sab., D. 18, 3, 2.

${ }^{345}$ Por isso, B. B. QUEIROZ DE MORAES, ao tratar da in diem addictio ter entendido que, na verdade, conceber o instituto sob a forma de condicionamento suspensivo ou como pacto de recolução condicionado ajeto a um contrato incondicionado, nenhum efeito prático teria - cf. Pacto de melhor comprador cit. (nt. 263 supra), p. 79. O mesmo entendimento, aliás, pode ser estendido à lex commissoria.

${ }^{346}$ Cf., nesse sentido, A. BuRdese, “Lex commissoria” cit. (nt. 26 supra), p. 14.

${ }^{347}$ Em geral, sobre as fases de desenvolvimento da primitiva venda romana - cf. U. VON LÜBтоw, Studien zum altrömischen Kaufrecht II, in Festschrift Paul Koschaker, Weimar, 1939, pp. 129 e ss. 
commissoria podido cumprir tal função ao condicionar, em qualidade de lex $\operatorname{dicta}^{348}$, unicamente a obrigação do vendedor à própria prestação. Isso porque, comportando-se como reflexo do bonae fidei iudicium, como pacto fundado sobre o comum consenso das partes, seus efeitos eram irradiados à inteira eficácia do contrato $^{349}$.

Já a valoração da lex commissoria em matéria de garantia como pacto ao qual é condicionada a definitiva extinção da obrigação, com o faltante pagamento por parte do devedor, não se deduz de forma tão imediata quanto ocorre com a venda. Afinal, ao menos em seus primórdios na fiducia cum creditore, esse efeito pareceria já estar compreendido na própria estrutura do negócio fiduciário, com a transferência resolúvel da propriedade ${ }^{350}$.

De qualquer modo, ao confrontar a construção da lex commissoria em matéria de garantia com a da primitiva lex commissoria em matéria de venda, não seria absurdo concluir que também possa a mais antiga lex commissoria ter representado um condicionamento suspensivo à obrigação de restituir, derivado da alienação fiduciae causa ${ }^{351}$.

Analogamente ao regime da venda, em que a condição era constituída pelo pagamento do preço por parte do comprador no termo acordado, nas garantias, a condição corresponderia ao adimplemento do crédito garantido, obviamente, também dentro do termo previamente acordado.

Em outras palavras, a lex commissoria traria como consequencia a impossibilidade de que o devedor fiduciário pudesse reaver a coisa dada em garantia, se antes do término do prazo não tiver adimplido. Após o término desse prazo, sendo definitiva a inadimplência, cessaria de vez essa possibilidade, com a extinção definitiva do negócio.

\footnotetext{
${ }^{348}$ Sobre a hipotética existência de um estado originário da lex commissoria como lex dicta, cláusula unilateralmente imposta pelo credor no próprio interesse - cf. F. WIEACKER, Lex commissoria cit. (nt. 266 supra), p. 43; E. LEVY, Zu den Rücktrittsvorbehalten cit. (nt. 369 supra), p. 109; G. G. ARCHI, La restituzione cit. (nt. 266 supra), pp. 328 e ss.

${ }^{349}$ Também se do ponto de vista dogmático resulta pouco compreensível como possa a obrigação do comprador ser condicionada à própria extinção - cf. R. HENLE, Die rechtliche Natur cit. (nt. 270 supra), p. 184.

${ }^{350}$ Cf. A. BURDESE, “Lex commissoria” cit. (nt. 26 supra), p. 15.

351 A. BURDESE levanta como um forte indício desta interpretação o sentido etimológico que se dá ao verbete - cf. "Lex commissoria” cit. (nt. 26 supra), p. 14..
} 
Assim, mesmo aparentemente pertencentes a campos tão diversos da prática negocial, ambos os pactos tiveram, ao menos em origem, a característica comum de condicionar suspensivamente "soluta ad diem pecunia" os efeitos dos negócios a que eram apostos ${ }^{352}$.

Caso seja desconsiderada a hipotética existência de um primitivo estágio em que apareceriam em qualidade de leges unilateralmente impostas pelo vendedor e pelo fiduciário no próprio e exclusivo interesse ${ }^{353}$, a lex commissoria, tanto em matéria de venda quando no que diz respeito às garantias, se apresenta como pacto adjeto a negócios de boa-fé.

Inicialmente entendida, então, como mecanismo de condicionamento suspensivo da obrigação fiduciária à restituição, a lex commissoria teria sido apta a exaurir o conteúdo do pactum fiduciae - caso se entenda que, de fato, o dever de restituir encontre a sua fonte na alienação fiduciae causa ${ }^{354}$ - servindo, ainda, como importante elemento de transição do negócio fiduciário à função de penhor.

Tal visão unitária das consequencias do condicionamento ao adimplemento do crédito garantido é compartilhada por uma parte da doutrina ${ }^{355}$, que, no entanto, não demonstra verdadeira preocupação em individuar os efeitos da lex commissoria como cláusula apta a afastar qualquer responsabilidade do credor fiduciário insatisfeito ao término do prazo $^{356}$.

A lex commissoria aliada ao pactum fiduciae ${ }^{357}$, na verdade, acaba tendo um duplo efeito: não apenas implica na transferência da coisa à definitiva

${ }^{352}$ Cf. item II.2.1.

${ }^{353} \mathrm{Em}$ analogia àquilo que se sustentou em matéria de venda, poder-se-ia também para a fiducia distinguir um estágio originário em que a lex commissoria apareceria em qualidade de lex dicta, cláusula unilateralmente imposta no próprio interesse do fiduciário - cf. a Erbe, Die Fiduzia, cit., p. 4 e ss.; H. KRELLER, cit. (nt. 72 supra), pp. 197 e 206.

354 Nesta teoria, à qual aderimos, e na correlativa ideia de uma precedência histórica da fiducia cum amico, bem se enquadra a nossa concepção da lex commissoria fiduciária. A aplicação do negócio fiduciário a escopo pignoratício se apresenta no sistema romano mais como um produto da especulação jurídica, guiada pelas necessidades da vida econômica e comercial - cf. R. HERZEN, Origine, cit., p. 68.

${ }^{355}$ Cf. Erbe, Die Fiduzia cit. (nt. 26 supra), pp. 36 e ss; H. SIBER, Römisches Recht in Grundzügen für die Vorlesung II - Römisches Privatrecht, Berlin, 1928, p. 122; Ascoli, Le origini cit. (nt. 46 supra), pp. 16 e ss.

${ }^{356} \mathrm{Cf}$, nesse sentido, A. BURDESE, “Lex commissoria” cit. (nt. 26 supra), p. 32.

${ }^{357}$ Alguns autores entendem que o acréscimo de uma cláusula assim entendida ao pactum fiduciae, já condicionante a obrigação fiduciária soluta pecunia, seja indispensável para fundar a 
propriedade do credor, em caso de inadimplemento, como também estabelece uma modalidade cronológica, através do termo, que lhe é inerente, para que a coisa seja restituída ao devedor, em caso de adimplemento ${ }^{358}$.

\subsection{Exegese de Pomp. 35 aD Sab., D. 18, 3, 2 E de UlP.} 30 AD ED., D. 18, 3, 3

Não obstante, em um primeiro momento, pareçam estranhos à matéria por nós tratada, a interpretação do conteúdo dos fragmentos a serem analisados é tema corrente (e nada pacífico) em diversos trabalhos ${ }^{359}$ que cuidam, com algum destaque, do instituto nas garantias reais.

À luz das considerações já feitas sobre a função estrutural da lex commissoria - mais especificamente, fiduciária -, já se torna mais facilmente individuável a razão do excursus pomponiano contido neste primeiro e significativo texto sobre o análogo pacto em matéria de compra e venda :

faculdade de satisfação imediata e direta do credor - cf. R. HERZEN, Origine, cit. (nt. 26 supra); P. F. GIRARD, Manuel élémentaire cit. (nt. 26 supra), p. 824; G. GROSSO, Appunti cit. (nt. 223 supra), p. 108; F. WIEACKER, Lex commissoria cit. (nt. 266 supra), p. 5.

${ }^{358}$ Nesse sentido - cf. A. BURDESE, “Lex commissoria” cit. (nt. 26 supra), p. 17.

${ }^{359}$ Os principais trabalhos que tratam do fragmento (ainda que incidentalmente) são: A. BURDESE, “Lex commissoria”" cit. (nt. 26 supra); A. BISCARDI, La lex commissoria cit. (nt. 22 supra); A. BISCARDI, Le garanzie, cit. (nt. 205 supra); E. AlBERTARIO, Sulla nullità cit. (nt. 359 supra); C. LONGO, Sulla "in diem addictio" cit. (nt. 262 supra), p. 43; G. ACUTIS, De lege commissoria cit. (nt.303 supra), pp. 40 e ss.; A. SACCHI, Sul patto commissorio cit. (nt. 90 supra). 
Pomponius libro 35 ad Sabinum, D. 18, 3, 2:

\begin{tabular}{|c|c|}
\hline $\begin{array}{l}\text { Cum venditor fundi }{ }^{360} \text { in lege ita caverit: } \\
\text { "si ad diem pecunia soluta non sit, ut } \\
\text { fundus inemptus sit, } 361 \text {, ita accipitur } \\
\text { inemptus esse fundus, si venditor inemptum } \\
\text { eum esse velit, quia id venditoris causa } \\
\text { caveretur: nam si aliter acciperetur, exusta } \\
\text { villa in potestate emptoris futurum, ut non } \\
\text { dando pecuniam inemptum faceret fundum, } \\
\text { qui eius periculo fuisset. }\end{array}$ & $\begin{array}{l}\text { Quando o vendedor de um terreno, em uma } \\
\text { cláusula }^{362} \text {, assim tiver expressado }{ }^{363} \text { : "caso } \\
\text { o preço não tenha sido pago no termo } \\
\text { que o terreno seja considerado não } \\
\text { comprado", desse modo, deve-se considerar } \\
\text { não comprado o terreno, <apenas> se } \\
\text { vendedor quiser que <o terreno> se } \\
\text { considere não comprado, porque tal cláusula } \\
\text { se expressaria em benefício do vendedor. De } \\
\text { fato, se diversamente se entendesse, } \\
\text { destruída pelo fogo uma casa de campo } \\
\text { estaria na faculdade do comprador, não } \\
\text { entregando o preço, considerar não } \\
\text { comprado o terreno } 366 \text {, } \\
\text { < diferentemente> teria estado a seu risco }\end{array}$ \\
\hline
\end{tabular}

${ }^{360}$ Ainda que, no transcorrer dos séculos, o sentido do substantivo fundus tenha variado significativamente, podemos afirmar com segurança que seu uso vem sempre relacionado à idéia de "coisas imóveis", seja em relação a uma construção urbana, seja em relação a um terreno rural cf. Fl. 8 institutionum, D. 50, 16, 211 ('fundi' appellatione omne aedificium et omnis ager continetur...").

${ }^{361}$ As considerações pertinentes à fórmula e objeto do instituto são tratadas separadamente - cf. II.2.1.

${ }^{362}$ Usam o termo "pacto", ao invés de cláusula - cf. I. L. GARCIA DEL CORRAL, Cuerpo del derecho cit. (nt. 40 supra), p. 911; H. HULOT - J. F. BERTHELOT, Les cinquantes livres cit. (nt. 40 supra), p. 572; G. VIGNALI (coord.), Corpo del diritto cit. (nt. 40 supra), p. 1.196.

${ }^{363}$ A tradução italiana mais recente acrescenta ainda à oração "per essere sicuro", cf. S. SCHIPANi (cur.) Iustiniani Augusti Digesta seu Pandectae - Digesti o Pandette dell'Imperatore Giustiniano III - Texto e traduzione - 12-19, Milano, GIuffrè, 2007, p. 365.

${ }^{364}$ Traduzimos por termo, por acreditar que a expressão melhor se adeque ao instituto estudado. A acepção, ainda que técnica de "diem" é muito mais ampla, cf. B. B. QUEIROZ DE MORAES, Pacto de melhor comprador cit. (nt. 263 supra), p. 136.

${ }^{365}$ Optou-se por tal tradução em função do conteúdo trazido no título De verborum significatione pelo fragmento Fl. 8 int. D. 50, 16, 211 ( “... sed in usu urbana aedificia 'aedes', rustica 'villae' dicuntur...”). Villa rustica - cf. S. SCHIPANI (cur.), Iustiniani Augusti cit. (nt. 363 supra), p. 365.

366 "risolvere la compravendita del fondo" - cf. S. SCHIPANI (cur.), Iustiniani Augusti cit. (nt. 363 supra), p. 365 .

367 "rischio e periculo" - cf. S. SCHIPANI (cur.), Iustiniani Augusti cit. (nt. 363 supra), p. 365. Outros autores, por sua vez, apenas falam em risco - cf. I. L. GARCIA DEL CORRAL, Cuerpo del derecho cit. (nt. 40 supra), p. 911; H. HULOT - J. F. BERTHELOT, Les cinquantes livres cit. (nt. 40 supra), p. 572; G. VIGNALI (coord.), Corpo del diritto cit. (nt. 40 supra), p. 1.196; O. BEHRENDS - R. KNÜTEL - B. KUPISCH - H. H. SEILER, Corpus Iuris Civilis (Text und Übersetzung) II (Digesten 1-10), Heidelberg, Müller, 1995, p. 478. 
O fragmento de Pompônio discute basicamente dois principais tópicos. No início do fragmento ("Cum venditor... quia id venditoris causa caveretur"), o jurista trata da potestividade do exercício da lex commissoria pela figura do vendedor, em cujo interesse a cláusula é estabelecida. Em outras palavras, verificado o termo, a ausência de pagamento por parte do comprador apenas resolveria o contrato se assim quisesse o vendedor, pois é o seu próprio benefício que justifica a existência da mencionada cláusula.

O segundo tópico é tratado na parte final do fragmento ("nam si aliter acciperetur... qui eius periculo fuisset”). A questão ali levantada, a cuja interpretação, como se verificará, prescinde fundamentalmente a análise da primeira parte do texto, diz respeito ao periculum rei, que, segundo Pompônio, deverá ser suportado pelo comprador.

Com relação ao primeiro tópico, a redação parece não levantar dúvidas $^{368}$ : O pacto, enquanto concluído no exclusivo interesse do vendedor ("quia id venditoris causa caveretur"), não pode ser feito valer contra a sua vontade, ou, logicamente, de quem a represente. A razão é simples: Qualquer contrária à essa regra representaria verdadeira incongruência ${ }^{369}$.

A leitura e compreensão dessa parte do texto, contudo, ganha particular relevância se analisada conjuntamente ao fragmento sucessivo, de Ulpiano, também sob o título "De lege commissoria":

${ }^{368}$ Enfaticamente, A. BURDESE, para o qual os fragmentos, por si só, já seriam suficientes para que se admitisse, por analogia, a aplicação de seu conteúdo à lex commissoria em matéria de garantia - cf. "Lex commissoria” cit. (nt. 26 supra), p. 21.

369 E. LEVY observa que tal incongruência não se verifica em relação às outras duas pactuações típicas que condicionam o contrato de venda, pactum displicentiae e in diem addictio, de que a primeira é no poder e interesse do comprador, a segunda no interesse e poder do vendedor - cf. Zu den Rücktrittsvorbehalten des römischen Kaufs, in Gesammelte Schriften II, Köln, Böhlau, 1963, p. 114. 
Ulpianus libro 30 ad edictum, D. 18, 3, 3:

\begin{tabular}{|c|c|}
\hline $\begin{array}{l}\text { Nam legem commissoriam, quae in } \\
\text { venditionibus adicitur, si volet venditor } \\
\text { exercebit, non etiam invitus. }\end{array}$ & $\begin{array}{l}\text { Porque da lex commissoria }{ }^{370} \text {, <mais } \\
\text { especificamente daquela> que se acrescenta } \\
\text { às vendas, fará uso o vendedor, <apenas> se } \\
\text { <assim> quiser, não <utilizando-a>, } \\
\text { também, contra sua vontade. }\end{array}$ \\
\hline
\end{tabular}

Aqui, numa clara confirmação à jurisprudência precedente ${ }^{371}$, o jurista estabelece que a lex commissoria terá seus efeitos irradiados ao negócio "si volet venditor exercebit", ou seja, se assim quiser o vendedor.

O problema que se coloca é se os textos, de fato, ainda que sob o mencionado título de compra e venda, possam também ser aplicados às garantias reais. A questão, contudo, é controversa. Comecemos com uma primeira corrente de idéias, mais antiga e majoritáira, da qual são importantes defensores A. BURDESE $^{372}$ e A. BISCARDI ${ }^{373}$.

Como já esclarecemos alhures ${ }^{374}$, é amplamente difusa a teoria de O. LENEL de que o livro 35 de Pompônio ad Sabinum e do livro 30 de Ulpiano ad edictum eram originariamente dedicados à fórmula da actio fiduciae.

Nesse sentido, tendo por base os mencionados estudos palingenéticos, defende A. BURDESE ${ }^{375}$ que a análise conjunta de ambos os fragmentos permite afirmar, com elevado grau de segurança, que a intenção originária dos juristas na construção desse seus conteúdos era a de, na verdade, referir-se à relação existente entre a lex commissoria e a fiducia cum creditore ${ }^{376}$.

É interessante notar que a aplicação do fragmento à garantia real serve de argumento contrário, inclusive, àqueles que se posicionaram a favor da excessiva rigidez do instituto, julgando que uma de suas principais causas de

${ }^{370}$ Sobre a opção pela não tradução do termo - cf. item II. 1.1.

${ }^{371}$ Cf. A. BISCARDI, La lex commissoria cit. (nt. 22 supra), p. 588.

372 "Lex commissoria" cit. (nt.26 supra), p. 21.

${ }^{373}$ La "lex commissoria" cit. (nt. 26 supra), p. 588.

${ }^{374}$ Cf. II.2.3.

${ }^{375}$ Lex commissoria" cit. (nt. 26 supra), p. 21.

${ }^{376}$ A. BURDESE utiliza esses argumentos, inclusive, para defender sua teoria sobre a origem de uma lex commissoria na própria fiducia, como expusemos no item II.1.2.1. 
extinção estava justamente na incontornável transferência da propriedade ao devedor ${ }^{377}$.

De qualquer modo, ainda que defenda a aplicação originária dos fragmentos à lex commissoria fiduciae, os argumentos de A. BISCARDI para chegar à mesma conclusão de A. BURDESE são bastante distintos - e, a nosso ver, mais interessantes e plausíveis.

Ao analisar conjuntamente as duas construções clássicas, A. BISCARDI $^{378}$ questiona as razões que teriam levado Pompônio a tratar da lex commissoria apenas na compra e venda, negligenciando o instituto nos anteriores fragmentos Pomp. 35 ad Sab. D. 13, 7, 6 e Pomp. 35 ad Sab. D. 13, 7, 8, sob o título "De pignoraticia actione, vel contra". Também extraídos do livro $35^{\circ}$, pela lógica leneliana, ambos se aplicariam à fiducia ${ }^{379}$.

Sem ter a intenção de apresentar um elenco exaustivo de traduções, acreditamos, contudo, de grande importância para nosso intento exegético a leitura de Pomp. 35 ad Sab., D. 13, 7, 6pr.:

Pomponius libro 35 ad Sabinum, D. 13, 7, 6pr.:

Quamvis convenerit, ut fundum Ainda que se tenha convencionado que te pigneraticium tibi vendere liceret, nihilo seja lícido vender um terreno dado em magis cogendus es vendere, licet solvendo garantia $^{380}$, não por isso <o credor> deve non sit is qui pignus dederit, quia tua causa ser obrigado a vendê-lo, ainda que não seja id caveatur. Sed Atilicinus ex causa adimplente aquele que tiver dado a <coisa

${ }^{377}$ Segundo A. WATSON, sendo responsável pelos riscos com a coisa durante o período em que dela fosse proprietário, não raras eram as vezes em que o credor, para se livrar de tal ônus, concedia a posse ao devedor, a exemplo do que mais tarde foi feito em relação ao penhor - cf. Roman Law \& Comparative Law, $1^{\text {a }}$ ed., Athens and London, The University of Georgia, 1991, p. 51.

Não por aí, é claro, cessam as vantagens do instituto que, ad es., prestava-se a evitar a venda fraudulenta por parte do devedor, ou o indevido concurso de credores sobre a coisa dada em garantia. Para outros exemplos - cf. C. LoNGO, Fiducia cum creditore cit. (nt. 58 supra), p. 798.

${ }^{378}$ A. BISCARDI, La lex commissoria cit. (nt. 22 supra), p. 144. Para o autor, os dois framentos mencionados, se analisados isoladamente, "non contengono traccie, neppure indirette, di una simile pattuizione" - cf. A. BISCARDI, Le garanzie, cit. (nt. 205 supra), p. 586.

${ }^{379}$ Uma grande parte da doutrina, especificamente ao livro 35 ad Sab. De Pompônio, é conforme ao pensamento de O. LENEL de que tratar-se-ia da fiducia ou, ao menos, como defende M. KASER, tanto da fiducia quanto do penhor - cf. TR, XLVII, 1979, p. 212. 113.

380 "fondo pignoratizio" - cf. S. SCHIPANI (cur.), Iustiniani Augusti cit. (nt. 393 supra), p. 


\begin{tabular}{|c|c|}
\hline $\begin{array}{l}\text { ogendum creditorem esse ad vendendum } \\
\text { dicit: quid enim si multo minus sit quod } \\
\text { lebeatur et hodie pluris venire possit } \\
\text { ignus, quam postea? Melius autem est dici } \\
\text { eum, qui dederit pignus, posse vendere et } \\
\text { accepta pecunia solvere id quod debeatur, } \\
\text { ta tamen, ut creditor necessitatem habeat } \\
\text { stendere rem pigneratam, si mobilis sit, } \\
\text { rius idônea cautela a debitore pro } \\
\text { ndemnitate ei praestanda. invitum enim } \\
\text { creditorem cogi vendere satis inhumanum } \\
\text { st. }\end{array}$ & $\begin{array}{l}\text { em> garantia, porque em teu interesse }{ }^{381}<a \\
\text { garantia> é expressa. Atilicino, porém, diz } \\
\text { que com causa }{ }^{382} \text { deva ser o credor forçado } \\
\text { a vendê<-lo>: o que ocorre, de fato, se o } \\
\text { débito for muito menor, e se possa vender a } \\
\text { <coisa dada em> garantia }{ }^{383} \text { a mais alto } \\
\text { preço hoje do que depois? É então melhor } \\
\text { dizer que aquele que tenha dado a <coisa } \\
\text { em> garantia }{ }^{384} \text { possa vendê-la e, com o } \\
\text { dinheiro recebido, pagar o que é devido, } \\
\text { porém de modo que o credor seja obrigado } \\
\text { a apresentar a coisa penhorada, caso seja } \\
\text { móvel, devendo antes ter sido prestada pelo } \\
\text { devedor suficiente } \\
\text { indenizatória } \\
\text { desumano } \text {. De fato é bastante contra a sua vontade seja } \\
\text { obrigado o credor a vender a <coisa dada } \\
\text { em> garantia. }\end{array}$ \\
\hline
\end{tabular}

Aqui se fala de pactum vendendi, e não já de lex commissoria, aludindo-se a uma disputa, provavelmente ${ }^{387}$ iniciada entre Sabino e Atilicino, sobre a possibilidade de obrigar o credor fiduciário a vender a coisa que lhe fora dada em garantia.

$\mathrm{Na}$ primeira frase ("Quamvis convenerit... quia tua causa id caveatur”), Pompônio estaria se referindo a Sabino, para, sucessivamente,

381 “causa" - - cf. I. L. GARCIA DEL CORRAL, Cuerpo del derecho cit. (nt. 40 supra), p. 747. Optamos por "interesse" por acreditar que melhor se adequa ao estudo, ainda que isso implique uma tradução diversa do mesmo verbete logo em seguida ("sed Atilicinus ex causa"). No mesmo sentido - cf. S. SCHIPANI (cur.), Iustiniani Augusti cit. (nt. 393 supra), p. 113.

382 "per ragione del caso concreto" - cf. B. NoORdRAVEN, Pomp., D. 13, 7, 6 pr. cit. (nt. 95 supra), p. 247.

383 “pegno" - cf. S. SCHIPANI (cur.), Iustiniani Augusti cit. (nt. 393 supra), p. 113.

384 “pegno” - cf. S. SCHIPANI (cur.), Iustiniani Augusti cit. (nt. 393 supra), p. 113.

385 "si debba prestare prima idonea garanzia che sarà tenuto del tutto indenne da ogni danno" , p. 113. "caución de indemnidad” - cf. I. L. GARCIA DEL CORRAL, Cuerpo del derecho cit. (nt. 40 supra), p. 747; "idonea cautela (...) per il rifacimento dei danni" - cf. B. NoORdRAVEN, Pomp., D. 13, 7, 6 pr. cit. (nt. 92 supra), p. 247.

${ }^{386}$ Cf., oportunamente, item II.3.

${ }^{387}$ Cf. A. BISCARDI, Le garanzie, cit. (nt. 205 supra), p. 587. 
reproduzir a opinião de Atilicino, e, na última frase ("melius autem est dici eum ... satis inhumanum est"), dar uma sua própria solução ao caso ${ }^{388}$.

Comparando as duas diferentes passagens dos livros 13 e 18 do Digesto, a dúvida sobre a ratio de Pompônio ainda ganharia reforço no uso de construções gramaticais e lexicológicas similares ${ }^{389}$, especialmente, em tal sentido, com o emprego do verbo "cavere".

A propósito da fiducia, determina-se que o pactum vendendi, instituto tratado nos fragmentos, deva ser estabelecido no interesse exclusivo do credor fiduciário (“... quia tua causa id caveatur...”). Igualmente, no caso da compra e venda, a lex commissoria deveria ser estabelecida no exclusivo interesse do vendedor (“... quia id venditoris causa caveretur...”).

Segundo A. BISCARDI ${ }^{390}$, a utilização das mesmas palavras nos textos teria sido intencional. Ao tratar da fudicia em Pomp. 35 ad Sab. D. 13, 7, 6 pr, Pompônio teria originariamente almejado "istituire un parallelo",391 com a análoga cláusula de compra e venda de Pomp. 35 ad Sab. D. 18, 3, $2^{392}$.

O autor ${ }^{393}$ ainda vai além: mais do que instituir tal paralelo entre os institutos, a intenção do jurisconsulto, se considerada isenta de interpolações ${ }^{394}$, poderia ser tanto a de mencionar o pactum vendendi, como se extrai da atual

${ }^{388}$ Nesse sentido - cf. B. NoOrdraVEn, Pomp., D. 13, 7, 6 pr. cit. (nt. 93 supra), p. 248.

389 Anteriormente, já O. GRADEWITZ, argumentando a expressão "emit ob sestertios" da manciatio pompeiana, tentou instaurar um paralelo entre a lex commissoria da venda e aquela fiduciária - cf. nt. 96. Adicionalmente, no mesmo sentido, F. SENN, La dation des arrhes, in NRH 37 (1913), p. 610.

${ }^{390}$ La "lex commissoria" cit. (nt. 22 supra), p. 144.

${ }^{391}$ La "lex commissoria” cit. (nt. 22 supra), p. 144. No mesmo sentido, A. BURDESE, “Lex commissoria" cit. (nt. 26 supra), p. 11, para o qual, de fato, a via mais simples para explicar a digressão sobre a lex commissoria da venda seja pensar que essa tenha sido ocasionada pelo discurso sobre o pacto análogo em matéria de fiducia.

${ }^{392}$ No mesmo sentido, E. LEVY, Zu den Rücktrittsvorbehalten cit. (nt. 369 supra), p. 113. Contra - cf. A. BuRDESE, "Lex commissoria” cit. (nt. 26 supra), p. 25; C. LONGO, Fiducia cum creditore cit. (nt. 57 supra), pp. 819-820.

${ }^{393}$ La "lex commissoria" cit. (nt. 22 supra), p. 144.

394 C. LONGO, não obstante concorde com a interpolação a esta parte do fragmento, acredita, diferentemente, que no texto original a menção ao instituto fosse ocasionado do tratamento do pacto de vender a fiducia certa die e não já pela lex commissoria - cf. Corso di diritto romano cit. (nt. 46 supra), p. 50; id., Fiducia cum creditore cit. (nt. 57 supra), p. 819. No mesmo sentido, SEGRÈ, Corso di diritto romano cit. (nt. 72 supra), pp. 84 e 152. 
leitura do texto, quanto, exclusivamente, a lex commissoria de que ora $\operatorname{tratamos}^{395}$.

Em outras palavras, portanto, o próprio fragmento Pomp. 35 ad Sab. D. 17, 7, 6 pr. poderia ter tratado diretamente do nosso instituto, e não do pactum vendendi. Isso porque, como também já mencionamos ao longo deste trabalho ${ }^{396}$, ao menos por determinado período, há quem defenda ${ }^{397}$ que tanto o pactum vendendi quanto o a lex commissoria poderiam, alternativamente, ser inseridos na fiducia.

Daí, igualmente, a justificativa de que também à lex commissoria nas garantias poderia ser estendido o mesmo entendimento da escola sabiniana em relação à lex commissoria nos contratos de compra e venda ${ }^{398}$. Ou seja, de que ambas devessem ser consideradas cláusulas estabelecidas no interesse exclusivo do vendedor.

A regra, no entanto, deve ser analisada com cuidado. Dentre os livros que compõem a Palingenesia de O. LENEL sobre a matéria, esse é provavelmente o mais polêmico ${ }^{399}$.

A principal justificativa de O. LENEL para a construção de sua teoria sobre o tratamento da fiducia, especificamente, no livro $35^{\circ}$ de Pompônio, reside na compreensão do vocábulo “eam” em Pomp. 35 ad Sab. D. 13, 7, 8, 3. Ali se lê “...vendere eam mihi liceret..." 400 , na hipótese em que o credor pode vender a coisa entregue em garantia.

${ }^{395}$ Contra - cf. E. LEVY, , Zu den Rücktrittsvorbehalten cit. (nt. 369 supra), p. 113.

${ }^{396} \mathrm{Cf}$., oportunamente, II.1.4.1.

${ }^{397}$ Cf. especialmente, A. BURDESE, “Lex commissoria” cit. (nt. 26 supra), p. 17.

${ }^{398}$ La "lex commissoria” cit. (nt. 22 supra), p. 146.

${ }^{399}$ Cf. C. Longo, Corso di diritto romano cit. (nt. 46 supra), p. 50.

${ }^{400} \mathrm{O}$ texto completo do fragmento seria: "Si annua bima trima die triginta stipulatus acceperim pignus pactusque sim, ut nisi sua quaque die pecunia soluta esset, vendere eam mihi liceret, placet, antequam omnium pensionum dies veniret, non posse me pignus vendere, quia eis verbis omnes pensiones demonstrarentur: nec verum est sua quaque die non solutam pecuniam, antequam omnes dies venirent. Sed omnibus pensionibus praeteritis, etiamsi una portio soluta non sit, pignus potest venire. Sed si ita scriptum sit: "si qua pecunia sua die soluta non erit", statim competit ei pacti conventio". 
A linguagem indicaria, em idade clássica, uma evidente ${ }^{401}$ relação com a fiducia, o que legitimaria a extensão da interpretação ao inteiro livro ${ }^{402}$. $\mathrm{O}$ uso de tal argumento pelos autores que pretendem contextar a aplicabilidade de Pomp. 35 ad Sab. D. 13, 7, 6, pr. também à fiducia cum creditore, contudo, não merece prosperar.

Isso porque, mesmo entre os partidários da corrente contrária ${ }^{403}$, não se exclui que se possa aceitar, a partir da teoria de O. LENEL, que o livro 35, ao tratar da fiducia, possa, ao mesmo tempo, também possa tratar do penhor. Um instituto, portanto, não excluiria o outro.

Ainda, considerando-se o conteúdo de Pomp. 35 ad Sab. D. 13, 7, 6, pr., parece muito mais adequado entender que é justamente à lex commissoria e não ao pactum vendendi que se aplicaria a “...quia tua causa id caveatur... "404.

Afinal, a venda da coisa dada em garantia, visando, em última medida, a restituição do excedente ao devedor ${ }^{405}$, não pode ser considerada cláusula estabelecida a favor, predominantemente, de única das partes ${ }^{406}$.

Nesse sentido, (a) a compatibilidade entre a estrutura do instituto e o conteúdo do livro $35^{\circ}$ de Pompônio, (b) a ampla aceitação da teoria de O. LENEL e (c) a escassez de argumentos daqueles que diversamente entendem, nos permitem afastar esta linha minoritária de pensamento e considerar que, ainda que, por si só, nossos fragmentos não sejam suficientes para justificar a aplicação à lex commissoria fiduciae, como pretendeu A. BURDESE, sua leitura conjunta com Pomp., D. 13, 7, 6 pr. constitui base suficiente para que se aceite tal interpretação.

Em outras palavras aceitar essa primeira e mais antiga corrente de idéias, ainda que se considerem as peculiaridades das construções de raciocínio dos autores que a defendem, grosso modo, significa entender que os fragmentos 250.

${ }^{401}$ Cf., no mesmo sentido, B. Noordraven, Pomp., D. 13, 7, 6 pr. cit. (nt. 92 supra), p.

402 Contra - cf., e.g., H. ANKUN, Alla ricerca della 'repromissio' e della 'satisdatio secundum mancipium', in Atti del IV Congresso Internazionale dell'Accademia Romanistica Constantiniana, Perugia, 1981, n. 7; C. LongO, Fiducia cum creditore cit. (nt. 57 supra), p. 890; B. NoOrdraven, Pomp., D. 13, 7, 6 pr. cit. (nt. 92 supra), p. 248.

${ }^{403}$ Cf. W. ERBE, Die Fiduzia cit. (nt. 26 supra), p. 44.

${ }^{404}$ Cf. A. BISCARDI, La lex commissoria cit. (nt. 22 supra), p. 588.

${ }^{405}$ Sobre o pactum vendendi - cf. item II.1.3.

${ }^{406}$ Contra - cf. B. NoORdRAVEN, Pomp., D. 13, 7, 6 pr. cit. (nt. 92 supra), p. 251. 
Pomp. 35 ad Sab. D. 18, 3, 2 e Ulp. 30 ad ed. D. 18, 3, 3 se aplicariam, também, à lex commissoria fiduciária.

Tal entendimento adquire prática relevância a propósito da incidência do periculum rei, mencionado na segunda parte de Pomp. 35 ad Sab. D. 18, 3, 2. Passemos, então, sem mais delongas ao segundo tópico.

Após esclarecer que a lex commissoria deva ser instituída em favor do devedor, o jurisconsulto, coerentemente, conclui o texto com o entendimento de que, enquanto se espera o verificar da condição dependente da vontade do comprador (pagamento do preço), o periculum não deva ser suportado pelo vendedor $^{407}$ ( “...in potestate emtoris futurum... qui eius periculo fuisset...”) ${ }^{408}$.

No fragmento, se configura a hipótese ${ }^{409}$ na qual o bem que constitui objeto do contrato de compra e venda - no caso, uma casa de campo - venha a ser destruído por um caso fortuito ou de força maior ( “...exusta villa...”).

Segundo A. BURDESE ${ }^{410}$, a incompatibilidade de uma similar situação à construção originária da lex commissoria como condição suspensiva não deixaria dúvidas de que Pompônio, implicitamente, tivesse a intenção de acolher a mais recente teoria do pacto de resolução suspensivamente condicionado ${ }^{411}$. Isso

${ }^{407}$ Vale lembrar que, no direito romano, vigorava a regra "periculum est emptoris" - cf., especialmente (inclusive para a indicação de bibliografia específica a respeito), E. C. SILVEIRA MARCHI, "Periculum rei venditae" e "periculum dotis aestimatae", in Labeo 47 (2001), p. 384 e ss.; Dos riscos pela perda fortuita da coisa vendida no direito romano, in Revista da Faculdade de Direito (Universidade de São Paulo) 96 (2001), pp. 45 e ss.; E. BETTI, "Periculum” - Problemi del rischio contrattuale in diritto romano classsico $e$ giustinianeo, in Studi in onore di P. De Francisci, v. 1, Milano, 1956, pp. 131 e ss.; . ARANGIO-RUIZ, La compravendita cit. (nt. 105 supra), p. 250; M. PENNITZ, Das "periculum" rei venditae" (ein Beitrag zum "Aktionenrechtlichen Denken” im römischem Privatrecht), Wien, Böhlau, 2000, pp. 247 e ss; F. HAYMANN, Textkritische Studien zum römischen Obligationenrecht, in SZ 11 (1919), pp. 254 e ss.; P. KRÜCKMANN, Einige Randfragen zum "periculum emptoris”, in SZ 59 (1939), pp. 1 e ss.

408 O inteiro argumento "nam si aliter..." foi considerado não clássico por G. VON BESELER, Romanistische Studien, in TR 8 (1928), p. 293 e F. WIEACKER, Lex commissoria cit. (nt. 266 supra), p. 26. Contra - cf. E. LEVY, Zu den Rücktrittsvorbehalten cit. (nt. 369 supra), p. 113.

${ }^{409}$ Uma "dimostrazione per assurdo" - cf. A. BISCARDI, La lex commissoria cit. (nt. 22 supra), p. 545.

410 “Lex commissoria” cit. (nt. 26 supra), p. 22.

${ }^{411}$ No mesmo sentido, G. G. ARCHI, La restituzione cit. (nt. 266 supra), p. 337.

Contra a teoria dominante, F. WIEACKER, sustentou serem as palavras de Pompônio explicáveis apenas sob o pressuposto da construção do condicionamento suspensivo - cf. Lex commissoria cit. (nt. 266 supra), p. 25. Contra - cf. E. LEVY, Zu den Rücktrittsvorbehalten cit. (nt. 369 supra), p. 113; G. G. ARCHI, La restituzione cit. (nt. 266 supra), p. 329; A. D’Ors, In diem addictio cit. (nt. 284 supra), p. 209; R. HENLE, Die rechtliche Natur cit. (nt. 270 supra), p. 169. 
sob o custo de abandonar a contrária opinião de Sabino, fundada sobre a antiga construção do condicionamento suspensivo da eficácia do contrato, que ele mesmo ainda seguia para a in diem addictio $^{412}$.

Essa, contudo, é uma hipótese bastante especulativa: nos textos de Pompônio nenhum outro argumento é encontrado para reforçá-la. Como já alegamos $^{413}$, estabelecer o exato período em que a condição resolutiva passou a ser aceita para o direito romano - se isto, de fato, ocorre ${ }^{414}$ - em nada mudaria ${ }^{415}$ os efeitos da lex commissoria, justamente por força do mencionado pacto de resolução ${ }^{416}$ acessório à obrigação principal.

Mais relevante, neste momento, é a análise da concreta solução dada pelo jurisconsulto ao problema. Mais do que ser tomada como uma posição já amplamente difundida no ordenamento romano, a incidência do periculum rei sobre o comprador, neste caso específico, poderia ser analisada não apenas em função da já mencionada potestividade de exercício da lex commissoria pelo vendedor, como também pela estrutura do próprio pacto fiduciário.

Como vimos anteriormente ${ }^{417}$, a oposição de um similar pacto a algum do modos derivados e solenes de transferência da propriedade tornava a obrigação unilateral do credor à restituição independente da formação do crédito garantido. O único nexo existente entre crédito e obrigação fiduciária, na verdade, consistiria no fato de que esta seria condicionado ao adimplemento daquele.

Em virtude de tal regra, chegou-se a considerar ainda mais absurda ${ }^{418}$ a hipótese prevista pelo fragmento, se analogamente aplicável aos direitos reais. Isso porque, verificada a transferência da propriedade ao credor, será sempre de

${ }^{412}$ Cf., por qaúltimo, A. D’Ors, In diem addictio cit. (nt. 284 supra), p.209; E. LEVY, , Zu den Rücktrittsvorbehalten cit. (nt. 369 supra), p. 114. Contra - cf. J. H. MiCHEL, L'influence de la lex venditionis sur les règles du contrat de vente, in RIDA 12 ( $3^{\mathrm{a}}$ série - 1966), cit. (nt. 139 supra), p. 337.

${ }^{413}$ Vide, oportunamente, itam II.2.2.

${ }^{414}$ Nesse sentido - cf. M. TALAMANCA, Istituzioni cit. (nt. 71 supra), pp. 251-252.

${ }^{415} \mathrm{Na}$ compra e venda, a condição afeta seus efeitos essenciais, quais sejam, a obrigação de colocar o comprador na posse pacífica da coisa e a obrigação de pagar o preço. Não afeta, por outro lado, seus elementos secundários, como é o caso do periculum - cf. R. HENLE, Die rechtliche Natur cit. (nt. 270 supra), p. 169.

${ }^{416} \mathrm{Cf}$. item II.2.2.

${ }^{417}$ Cf., novamente, item II.2.2.

${ }^{418}$ Cf. A. BISCARDI, La lex commissoria cit. (nt. 22 supra), p. 541. 
seu interesse criar mecanismos para prolongar os efeitos da mora debitoris, uma vez que, verificado o perecimento da coisa, não incorreria em qualquer responsabilidade.

Ao devedor, portanto, a proteção ficaria por conta da máxima "ut inter bonos bene agier oportere et sine fraudatione, 419 , à qual o credor é vinculado. Isso, permitiria, por exemplo, o surgimento de uma obrigação à restituição, caso o credor tivesse encontrado satisfação independentemente da garantia ${ }^{420}$.

\section{A PROIBIÇÃo de CONSTANTINo}

Reputada como lícita durante significativo período do desenvolvimento do direito romano, teve a lex commissoria corrente aplicação nas atividades negociais até sua proibição por Constantino, em $320^{421}$.

Para V. LOJACONO ${ }^{422}$, a plena recepção do instituto ao longo de séculos, considerado seu início com a arcaica fiducia cum creditore ${ }^{423}$, teria tido duas principais razões:

a) De índole geral: a moral unitária dos romanos do período clássico não repugnava a hipótese de que a coisa dada em garantia, ainda que de valor muito superior ao total do débito, passasse ao pleno domínio do credor, no caso de faltante pagamento.

b) De índole jurídica: a lex commissoria estruturava-se de modo bastante análogo à fiducia, que até o advento do penhor imperou como principal forma de garantia real ${ }^{424}$, no que tange ao escopo satisfativo proporcionado ao credor pelos amplos poderes adquiridos sobre a coisa ${ }^{425}$.

${ }^{419}$ Cf. Cic., De off. 3, 17, 70.

${ }^{420}$ Cf. A. BURDESE, "Lex commissoria" cit. (nt. 26 supra), pp. 116-117.

${ }^{421}$ Cf. C. TH. 3, 2,1 (de 320 d.C.) e C. 8, 34, 3 (de 326 d.C.).

${ }^{422}$ Il patto commissorio cit. (nt. 204 supra), p. 10.

${ }^{423}$ Cf. item II.1.2.1.

${ }^{424}$ B. BIONDI lembra que a fidúcia, nos tempos mais antigos, tem uma função importantíssima, que diminui à medida que a ordem jurídica conhece novos negócios e se 
Infelizmente, as fontes não trazem qualquer indício de que, de fato, a aplicação da lex commissoria como pacto adjeto aos contratos de garantia tenha causado inconvenientes tão insuportáveis que pudessem justificar sua proibição. No máximo, empregam termos como "captiones" e "asperitas" 426 , demasiadamente vagos para que se possa extrair qualquer conclusão segura ${ }^{427}$.

Essa ausência de meios justifica, em certa medida, o porquê de tão pouco se refletir sobre as razões que eventualmente tenham levado Constantino a expedir semelhante regra. Enquanto os poucos trabalhos ${ }^{428}$ de direito romano que cuidam do tema, preocupam-se com a mera reconstrução do instituto (por si só, já bastante dificultosa, dada a escassez de fontes), os trabalhos de direito civil ${ }^{429}$, em regra, tendem a simplesmente ignorar o desenvolvimento histórico do instituto.

Dentre os argumentos jurídicos possíveis, aquele levantado no item "b" costuma ser considerado o principal ${ }^{430}$. Se bastante análogos quanto à sua estrutura, estabelecer um paralelo entre a extinção da fidúcia e do pacto comissório é tarefa a que, uma vez mais, faltam indícios textuais.

$\mathrm{O}$ fato de o momento de desaparecimento de ambos os institutos ter sido praticamente concomitante ${ }^{431}$, de fato, não deixa de ser bastante curioso. No caso da fiducia, porém, as razões são bastante claras: desapareceu junto com os atos formais de transferência de que dependiam os efeitos do pactum fiduciae, quais sejam, a mancipatio e a in iure cessio.

eliminam algumas formalidades que não respondiam às necessidades sociais - cf. B. BIONDI, Istituizioni cit. (nt. 69 supra), p. 196.

${ }^{425}$ No mesmo sentido, C. Longo, Corso di diritto romano cit. (nt. 46 supra),p. 163; B. BIONDI, Istituizioni cit. (nt. 69 supra), 196; A. BURDESE, “Lex commissoria” cit. (nt. 26 supra), p. 43; A. BISCARDI, La lex commissoria cit. (nt. 22 supra), p. 515.

426 . C. TH. 3, 2, 1 (de 320 d.C.) e C. 8, 34, 3 (de 326 d.C.).

${ }^{427}$ Contra, cf. V. LOJACONO, Il patto commissorio cit. (nt. 204 supra), p. 10.

${ }^{428}$ Cf. A. BURDESE, "Lex commissoria" cit. (nt. 26 supra), pp. 44-45; A. BISCARDI, La lex commissoria cit. (nt. 22 supra), p. 412; F. WIEACKER, Lex commissoria cit. (nt. 266 supra), p. 24.

${ }^{429}$ A serem oportunamente analisados - cf. item III.

${ }^{430}$ Cf. C. LONGO, Corso di diritto romano cit. (nt. 46 supra), p. 163; A. BURDESE, “Lex commissoria” cit. (nt. 26 supra), p.44; A. BISCARDI, La lex commissoria cit. (nt. 22 supra), p. 512.

${ }^{431}$ Estima-se que a fidúcia romana caiu em desuso no decorrer dos séculos IV e V d.C. cf., entre outros, A. BURDESE, "Lex commissoria” cit. (nt. 26 supra), pp. 44-45; V. LOJACONO, Il patto commissorio cit. (nt. 204 supra), p. 8. 
A esses argumentos somar-se-ia, ainda, o fato de que a inexistência quase total de instituições financeiras que marcou o período de provável surgimento do instituto acabava por justificar a exigência de uma certa segurança por parte daquele que entregava o próprio dinheiro, suportando todos os riscos de um empréstimo privado ${ }^{432}$.

Já em período mais tardio, o aumento da circulação do crédito levou à criação de mecanismos alternativos, talvez menos gravosos ao devedor, como o empréstimo sob juros ${ }^{433}$. A prática do anatocismo, aliás, jamais chegou a ser totalmente vetada pelo direito romano como ocorreu no direito canônico ${ }^{434}$. Preferiram os romanos sua regulamentação, sob critérios que consideravam razoáveis para a quantificação de taxas ${ }^{435}$.

À questão jurídica, soma-se, ainda, o novo influxo de ideias trazidas pelo Cristianismo. O texto contido no Corpus Iuris Civilis não é apenas resultado da expansão política de Roma, do desenvolvimento de seu comércio e vida social, bastante influenciada pelo contato com a cultura e a civilização helênicas ${ }^{436}$. A

${ }^{432}$ Cf. V. LojaCONO, Il patto commissorio cit. (nt. 204 supra), p. 8.

${ }^{433}$ A usura é trazida nas fontes pelo termo usura, e é provável que a prática tenha se espalhado, a partir dos séculos II e II a.C., às províncias romanas através, inicialmente, das relações comerciais matítimas - cf. G. CERVENCA, Usura (diritto romano), in E.D. , Milano, 1992, XLV, pp. 1125 e ss. Sobre o tema, de modo geral - cf. M. BIANCHINI, La disciplina degli interessi convenzionali nella legislazione giustinianea, in Studi in onore di A. Biscardi II, Milano, 1982, pp. 391 e ss.; C. FADDA, Le usurae quae officio iudicis praestantus (1886-1887), in Studi e questioni di diritto I, Napoli, 1910, pp. 231 e ss.; G. ROTONDI, Vecchie e nuove tendenze per la repressione dell'usura, in Rivista dir. Civ., 1911, pp. 243 e ss.; U. SANTARELLI, Il divieto delle usure da canone morale a regola giuridica - Modalità ed esiti di un trapianto, in Riv. Storica del diritto italiano, LVI (1993), 51-73.

${ }^{434}$ É na patrística, especialmente dos séculos IV e V, que a proibição da usura ganha mais força - cf., entre outros, C. FADDA, Le usurae cit. (nt. 433 supra), pp. 20 e ss.

${ }^{435}$ De modo geral, a questão do anatocismo pode assim ser resumida: Começa com a lex Cornelia do ano 89, que proíbe aos aliados de conceder empréstimo a Roma de modo a evitar a saída de dinheiro da cidade; à lex Valeria de 87 que reduz os débitos de 25\%, à lex Gabina de 67, com a qual viriam pré-dispostos ulteriores remédios que pudessem frear a usura; e, por fim, a um Senatusconsulto do ano 55 a.C., que fixou os juros em $12 \%$ ao ano, tava que remete aos tempos de Nero (54 d.C.) e de Trajano (98 d.C.). A seguir, no período compreendido entre a morte de Alexandre Severo (235 d.C.) e aquele do império que termina com Justiniano (565 d.C.), a usura centesima sofre uma profunda transformação, especialmente por obra de Constantino, que distingue o capital em frutos e em dinheiro. No primeiro caso era consentida a restituição do capital e de juros até a terceira parte do próprio capital, enquanto no segundo era aceita a pactuação de juros não superiores às centesimae mensais - cf. G. Cervenca, v. Usura cit. (nt. 433 supra), p. 1127; U. SANTARELLI, Il divieto delle usure cit. (nt. 433 supra), pp. 10 e ss.

436 AlEXANDRE CORREA, $O$ estoicismo no direito romano, Tese (Livre Docência), São Paulo, Faculdade de Direito da USP, 1950, pp. 4 e ss. 
obra também encerra ideais que representam a identidade desse novo período da vida romana, sendo os valores trazidos pela ética cristã inerentes à sua formação.

É o que se verifica, em especial, na obra de Constantino, correspondente ao período de definitiva transição oficial à nova religião ${ }^{437}$. De modo geral, a tendência da legislação do período é justamente a de mudar a forma como as garantias eram então tratadas ${ }^{438}$ : credor e devedor são colocados em um plano igualitário $^{439}$ a partir de ideais de benevolência e compaixão em relação a esse último ${ }^{440}$.

Essa é justamente a lógica que circunda o desenvolvimento do favor debitoris $^{441}$, ou seja, a tendência que se verificou, principalmente a partir

${ }^{437}$ Sobre a relação das decisões de Constantino com o cristianismo - cf., especialmente, E. Albertario, Alcune osservazioni sulla legislazione di Costantino, in Actis Congressus Iuridici Internationalis, v. 1, Roma, 1934, pp. 69-79; G.G.ARCHI, Indirizzi e problemi del sistema contrattuale nella legislazione da Costantino a Giustiniano, in Studi in Onore di Contardo Ferrini, Milano, Hoepli, 1946, pp. 661 e ss.; C. CARASSAI, La politica religiosa di Costantino il Grande, Roma, Società Romana di Storia Patria, 1901, pp. 2 e ss.; G. CRIFÒ, Cristianesimo e istituzioni politiche, [estratto], pp. 1 e ss.; P. De FRANCISCI, Recensioni a Salvatore Calderone, Costantino e Il Cattolicesimo, I, Firenze, 1962, pp. 255 e ss.; A. MONACI, La visione e il labaro di Costantino, Roma, L. Ricca, 1913, pp. 3 e ss.

${ }^{438}$ B. BIONDI, Il diritto romano cristiano - Orientamento religioso della legislazione. v.1. Milano: Dott. A. Giuffrè, 1952, p. 215.

${ }^{439}$ F. DE MARTINO, Individualismo e diritto romano privato, $22^{\mathrm{a}}$ ed. , Torino, Giappichelli, 1999, p. 45.

${ }^{440}$ B. BIONDI, Il diritto romano cristiano - La Famiglia - Rapporti Patrimoniali - Diritto Pubblico. v. 3. $1^{\text {a }}$ ed. Milano: Giuffrè, 1952, p. 219.

${ }^{441} \mathrm{O}$ favor debitoris, de fato, consiste na tendência que se verificou, a partir dos imperadores cristãos, de que a proteção ao devedor fosse adotada como causa favorabilis nas fontes jurídicas romanas, em contraposição à postura adotada no período clássico, que se apoiava substancialmente no interesse do credor. Nesse sentido, é criada uma nova orientação do direito das obrigações: o devedor não é uma parte, de que se possa pretender inexoravelmente a prestação, mas é um homem que se encontra em um particular estado de debilidade. Sobre o princípio, cf., especialmente, J. C. MOREIRA ALVES, As normas de proteção ao devedor e o "favor debitoris" - Do Direito Romano ao Direito Latino-Americano, In Notícia do Direito Brasileiro III, Brasília, UNB, 1997; J. C. Moreira Alves, $O$ "favor debitoris" como princípio geral de direito, in Revista Brasileira de Direito Comparado, n. 26, Rio de Janeiro: Instituto de Direito Comparado LusoBrasileiro, 2004; I. M. POVEDA VELASCO, A execução do devedor no Direito Romano "Beneficium competentiae", 1ª ed, São Paulo, Paulista, 2002.

Importa, no entanto, lembrar que já a Lei das XII Tábuas trazia a preocupação com o que mais tarde considerou-se, grosso modo, uma tendência à atenuação de regras. É o que se vê, e.g., na L. XII Tab. 3, 3, com a faculdade atribuída ao credor de submeter o devedor inadimplente a um peso menor (“...aut si volet minore vincito...”); na L. XII Tab. 3, 4, em que tal faculdade se estende à possibilidade de que também aumente sua alimentação diária, além dos limites legais, caso não tenha meios próprios de subsistência ( “... si volet, plus dato...”); na L. XII Tab. 1, 3, com a obrigação de providenciar um jumento à parte intimada para comparecer em juízo que esteja doente ou velha (“... si morbus aevitasve vitium escit, [qui in ius vocabit] iumentum dato...”); e, por fim, na L. XII Tab. 2, 2, a regra anterior também se estende no caso de doença ou grave 
dos imperadores cristãos, de que a proteção ao devedor fosse adotada como causa favorabilis nas fontes jurídicas romanas, em contraposição à postura adotada no período clássico, que se apoiava substancialmente no interesse do credor.

Nesse sentido, é criada uma nova orientação do direito das obrigações: o devedor não é uma parte, de que se possa pretender inexoravelmente a prestação, mas um homem que se encontra em um particular estado de debilidade.

Vale, contudo, lembrar que o favor debitoris não significou a anulação do regime jurídico que visa a proteção do crédito ou a universal remissão do débito. Antes, resultou na humanização ${ }^{442}$ de regras jurídicas.

impedimento (“...eo dies diffissus esto...”). A análise da Lei das XII Tábuas também deve levar em conta o fato de que muitas de suas mais severas normas sequer encontraram aplicação prática. É o que ocorre, e.g., com a prescrição que permitia a divisão do corpo do devedor (L. XII Tab. 4, 6). Sobre ela, A. Gellio $(20,1,52)$ é categórico ao afirmar que, na tradição romana, não há qualquer indício de uma execução nestes moldes - cf. Noctes atticae, 20, 1, 52 (“...dissectum esse antiquitus neminem equidem legi neque audivi..."). Essa notícia é importante na medida em que é forte indicador de que, por todo o longo período de vigência da lei, a opinião pública e o costume deviam repudiar tal prática, que, em verdade, nenhum benefício trazia ao credor.

No mesmo sentido é o testemunho de Gaio, que, ao comentar que a gravíssima pena para o furtum manifestum baseada na Lei das XII Tábuas vem sucessivamente mitigada em uma pena quádrupla para o valor da coisa roubada - cf. 3, 189 (“...sed postea improbata est asperitas poenae, et tam servi persona quam ex liberi quadrupli actio praetoris edicto constituta est"). Ainda, agora tratando da poena sacramenti no antigo processo para legis actiones, afirma que na vindicatio in libertatem, a pena era sempre de 50 asses, ainda que o indivíduo fosse de valor superior aos mil asses - cf. 4, 14 (“...favore scilicet libertatis ne onerarentur adsertores").

Também na questão dos estrangeiros, antes mesmo do cristianismo, em especial a partir do século II a.C, há a invocação da clemência para indicar as razões de tais mudanças no tratamento dos estrangeiros - cf, especialmente, Cic., in Verr., 2, 5, 29, 74; Liv. 45, 4, 7; 30, 42, 17; 33, 12, 7.

Por fim, importa lembrar que, ao lado do favor debitoris desenvolve-se também o favor libertatis. A escravidão, fenômeno comum a todo o mundo antigo, não é em Roma propriamente uma instituição cruel: São notáveis os exemplos de benevolência em relação aos escravos domésticos e a posição de destaque assumida por muitos deles, moral e economicamente. A tendência, na verdade, é sempre de flexibilização, com a imposição de normas contra os padrões cruéis - cf. C. A. MASCHI, "Humanitas" romana cit. (n. 2 supra), pp. 269-270. Ainda sobre a relação entre a escravidão e a humanitas, cf., especialmente, H. WALLON, Histoire de l'esclavage dans l'antiquité, v. 3, $2^{\mathrm{a}}$ ed., Paris, Hachette, 1879, pp. 1-47.

Em especial a partir do século II a.C, há a invocação da clemência para indicar as razões de tais mudanças no tratamento dos estrangeiros - cf, especialmente , Cic., in Verr., 2, 5, 29, 74; Liv. $45,4,7 ; 30,42,17 ; 33,12,7$.

${ }_{442}$ Sobre a polissemia de humanitas nas fontes - cf., especialmente, B. BIONDI, Il Diritto Romano Cristiano - Orientamento religioso della legislazione, v. 1, Milano, Giuffrè, 1952, pp. 148 e ss.; B. BIONDI, "Humanitas" nelle leggi degli imperatori romano-cristiani, in Fontes Ambrosiani, .n. 26, Firenze, L.S. Olschki, 1951, pp. 81-94; F. SCHULZ, Prinzipien des römischen Rechts, München und Leipzig, Duncker \& Humblot, 1934, pp. 128-150; S. RicCOBONO JR., "Humanitas", in Il Circcolo Giuridico (1950), Palermo, Michele Montaina, 1950, pp. 1-24; S. RICCOBONO JR., L'idea di "humanitas" come fonte di progresso del dirito, in Studi in onore di 
Os pontos até aqui levantados, ressalta-se uma vez mais, são meras conjecturas sobre as razões que possam ter levado à proibição da lex commissoria, reproduzida à exaustão em inúmeros ordenamentos modernos ${ }^{443}$.

Passa-se então à exegese dos principais fragmentos relacionados à regra.

3.1. EXEgeSe de TeXtos POLÊMicos Relativos ì PROIBIÇÃo

\subsubsection{EXEGESE DE C. TH. 3, 2, 1 E C. 8, 34, 3}

A proibição da lex commissoria é trazida nas fontes em dois fragmentos de origem imperial ${ }^{444}$ :

Biondo Biondi, v. 2, Milano, Giuffrè, 1963, pp. 585-614; C. A. MASCHI, "Humanitas" romana e "caritas" cristiana come motivi giuridici, in JUS - Rivista di scienze giuridiche I, Milano, Università Cattolica del Sacro Cuore, 1950, pp. 266-274; C. A. MASCHI, "Humanitas" come motivo giuridico - con un esempio nel diritto dotale romano, in Annali Triestini, v. 18, Trieste, Università di Trieste, 1948, pp. 3-102; H. KRÜGER, Die "humanitas" und die "pietas" nach den Quellen des römischen Rechts, in SZ 19 (1898), pp. 6-58; A. PALMA, Humanior interpretario 'Humanitas" nell'interpretazione e nella normazione da Adriano ai Severi, Torino, G. Giappichelli, pp. 1-214.

${ }^{443}$ Cf. item III.1.

No direito canônico, a proibição é trazida em um decreto do Papa Gregório IX, do século XIII, que nada mais fez do que repetir a proibição de Constantino - cf. Decret. 3, 21, 7, X (de 1.212 d.C.).

${ }_{444}$ Os principais trabalhos que tratam do fragmento (ainda que incidentalmente) são: A. BURDESE, "Lex commissoria" cit. (nt. 26 supra); A. BISCARDI, La lex commissoria cit. (nt. 22 supra); A. BISCARDI, Le garanzie, cit. (nt. 205 supra); E. AlBERTARIO, Sulla nullità cit. (nt. 359 supra); V. LOJACONO, Il patto commissorio cit. (nt. 204 supra); O. BREGLIA, Patto commissorio, Roma, Athenaeum, 1939, pp. 4 e ss.; C. M. BIANCA, Il divieto del patto commissorio, Milano, Giuffrè, 1957. 
Constantinus, C. Th. 3, 2, 1 (de 320 d.C):

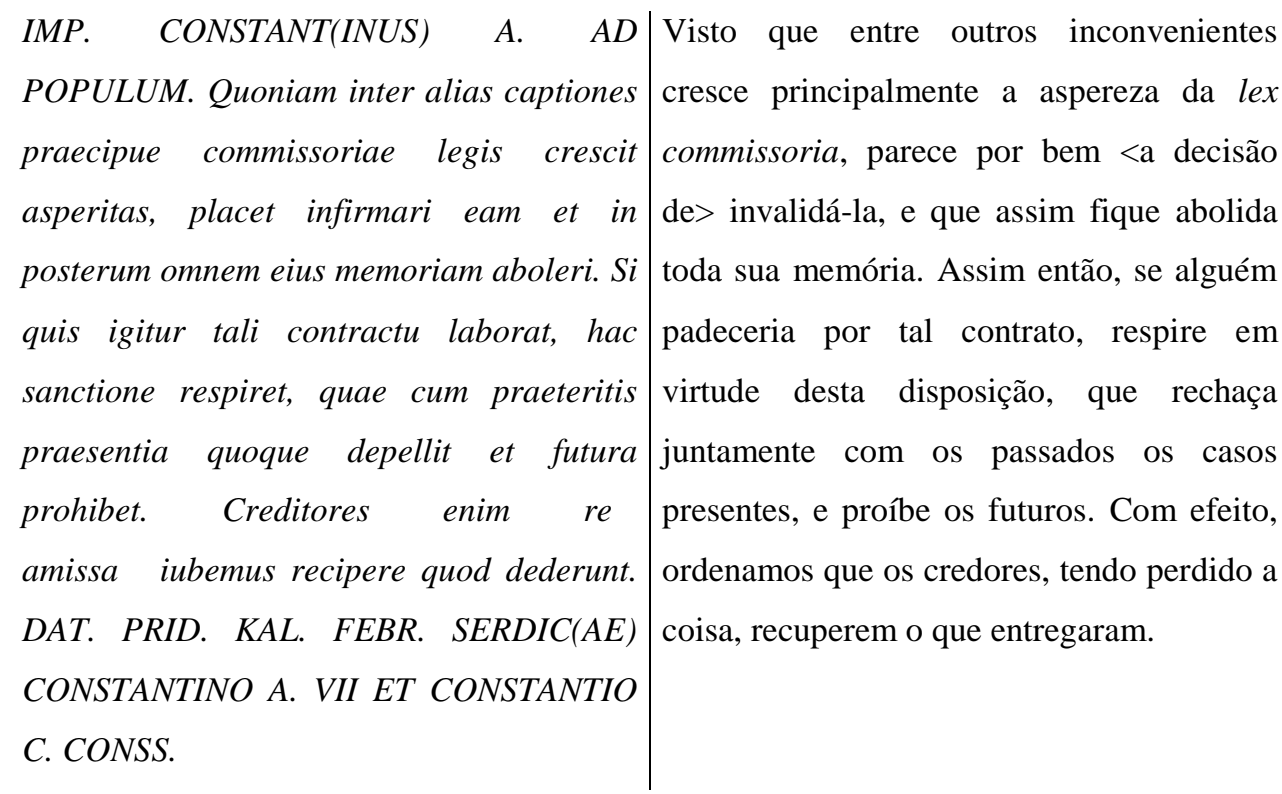

Constantinus, C. 8, 34, 3 (de 326 d.C.) ${ }^{445}$ :

Imperator Constantinus. Quoniam inter alias captiones praecipue commissoriae pignorum legis crescit asperitas, placet infirmari eam et in posterum omnem eius memoriam aboleri. 1.Si quis igitur tali contractu laborat, hac sanctione respiret, quae cum praeteritis praesentia quoque depellit et futura prohibet. Creditores enim re amissa iubemus recuperare quod dederunt * CONST. A. AD POP. *<A 326 D. II K. FEBR. SERDICAE CONSTANTINO A. VII ET CONSTANTIO C. CONSS.>
Visto que entre outros inconvenientes cresce principalmente a aspereza da lex commissoria pignoribus, parece por bem <a decisão de> invalidá-la, e que assim fique abolida toda sua memória. Assim então, se alguém padeceria por tal contrato, respire em virtude desta disposição, que rechaça juntamente com os passados os casos presentes, e proíbe os futuros. Com efeito, ordenamos que os credores, tendo perdido a coisa, recuperem o que entregaram.

De modo bastante direto $^{446}$, o instituto passa a ser expressamente vedado no Codex Theodosianus, entre os títulos "de contrahenda emptione"

445 A discrepância entra as datas apontadas pelo Codex Theodosianus e pelo Codex justinianeu deve-se, na verdade, a um equívoco deste último. Como aponta V. LOJACONO, não há notícia de qualquer constituição que efetivamente tenha sido emanada em Sardica no ano de 326 cf. Il patto commissorio cit. (nt. 204 supra), p. 10. 
(C.Th. 3, 1), “de patribus qui filios distraxerint" (C.Th. 3,3) e "de aediliciis actionibus" (C.Th. 3,4).

É curioso notar a evidente preocupação com os efeitos da proibição, atribuídos ex tunc (" ... quae cum praeteritis praesentia quoque depellit et futura prohibet" $)^{447}$, sem que, para tanto, sequer seja apresentada qualquer definição daquilo cuja memória se pretende abolir (" ... in posterum omnem eius memoriam aboleri...").

De um modo geral, as regras emanadas por Constantino, a exemplo de tantas outras constituições imperiais, têm eficácia ex nunc, ou seja, apenas atingem relações constituídas após sua decretação ${ }^{448}$. No caso da lex commissoria, porém, a irradiação de seus efeitos é igualmente estendida a todos os acordos celebrados em momento anterior.

A opção do imperador pela retroatividade, em oposição àquela que seria a regra no direito romano ${ }^{449}$, não deixou de causar certo espanto a parte da doutrina, que a considera uma importante inovação ${ }^{450}$.

${ }^{446}$ Tão direto que V. LOJACONO refere-se a seus termos como sendo "precisi, espressivi e inequivocabili" - cf. Il patto commissorio cit. (nt. 204 supra), p. 8.Contra, A. BISCARDI, para o qual a proibição de Constantino, na verdade, visou proibir a prática oriental da automática redução da coisa dada em garantia em propriedade do credor - cf. La lex commissoria cit. (nt. 22 supra), pp. 230 e ss.

447 A Constituição em exame pertence, na verdade, a um Edito maior, do qual essa representou apenas que um capítulo. A esse mesmo Edito pertence também Const., C.Th. 8, 16 (de 320 d.C.), que abolia as penas e as restrições sancionadas pela Lex Iulia para os solteiros e aqueles que não tinham filhos.

${ }^{448}$ Cf., e.g., o supramencionado Const., C.Th. 8, 16 (de 320 d.C.).

449 De fato, não há, mesmo no direito romano clássico, qualquer princípio absoluto que estabeleça a vedação da retroatividade de normas jurídicas. Cícero, inclusive, informa que leis civis continham geralmente cláusulas proibindo sua retroatividade - cf. In Verr. 17, 109. O mesmo, no entanto, não ocorreria com o ius honorarium, que, por sua própria natureza, aplicava-se retroativamente, porquanto o magistrado concedia a ação ou a denegava no momento em que as partes litigantes compareciam à sua presença. Isso possibilitaria afirmar que o princípio a ser aplicado no caso era o do edito de tal magistrado, ainda que o fato tivesse ocorrido durante a magistratura de um de seus antecessores cujo edito dispusesse, a respeito, de modo diverso - cf., nesse sentido, M. KASER, Das römische Privatrechts cit. (nt. 119 supra), p. 56.

Já no direito pós-clássico, uma constituição de Teodósio I, em 393 d.C., estabeleceu a regra de que as leis dispõem apenas para o futuro - cf. C. Th. 1, 1, 3 (de 393 d.C.). Décadas mais tarde, em 440 d.C., Teodósio II e Valentiano III confirmaram seu conteúdo, admitindo, porém, que a lei nova pudesse ser retroativa quando expressamente o declarasse - cf. C, 1, 14, 7 (440 d.C). Sobre a discussão quanto a eventuais interpolações neste último fragmento - cf. G. BROGGINI, $L a$ retroatività della lege nella prospectiva Romanistica, in Coniectanea (Studi di Diritto Romano), Milano, 1966, p. 398.

${ }^{450}$ O. BREGLIA, Patto commissorio cit. (nt. 444 supra), p. 6. 
Há, todavia, quem ${ }^{451}$ entenda ser tal retroatividade inerente a regras que prescrevam, ainda que genericamente, a proibição de convenções contrárias à boafé e aos bons costumes. Logo, para esses autores, antes mesmo de ser considerada contrária ao direito, a lex commissoria já deveria encontrar-se proibida na prática, como convenção contrária ao que seria socialmente aceitável.

A reforçar a tese estaria o emprego de "captiones" e "asperitas" no texto. Para V. LOJACONO ${ }^{452}$, tais termos não poderiam ser mais apropriados: enquanto o primeiro exprime a fraude e ganância características da lex commissoria, o segundo denuncia a gravidade do dano a ser suportado pelo devedor.

No entanto, a hipótese levantada, por si só, não constitui argumento suficiente para justificar qualquer proibição ou desuso precedente. Contrariamente, neste caso, questionar-se-ia a necessidade de que fossem atribuídos efeitos retroativos aos pactos celebrados antes de 320 d.C., se não fosse a lex commissoria instituto de aplicação frequente ou, ao menos, amplamente $\operatorname{aceita}^{453}$.

Ainda quanto aos efeitos, como última observação, deve-se apontar o caráter cogente da disposição de Constantino ${ }^{454}$. Qualquer convenção contrária à proibição, portanto, deveria considerar-se inevitavelmente nula, ainda que contasse com a anuência do devedor ${ }^{455}$.

${ }^{451}$ Cf., nesse sentido, R. T. Troplong, Du natissement, du gage et de l'antichrèse Commentaire du titre XVII, livre III, du Code Civil, t. 19, Paris, Charles Hingray, 1847, p. 108.

${ }^{452}$ cf. Il patto commissorio cit. (nt. 204 supra), p. 10. Para o autor, contudo, os argumentos que acreditam que a decisão de Constantino foi uma inovação são demasiadamente vagos e genéricos para provar que a retroatividade fosse inerente a pactos similares. No máximo, poder-seia falar de uma tendência das fontes romanas neste sentido.- cf. V. LOJACONO, Il patto commissorio cit. (nt. 204 supra), p. 11.

${ }^{453}$ Nesse sentido - cf. E. Albertario, Sulla nullità cit. (nt. 359 supra), pp. 480 e ss. O autor, inclusive, afasta a possibilidade de que sejam utilizados os fragmentos Paul. 1 decret., D. 4, 4, 38; Alex. Sev., C. 8, 34, 1 (de 222 d.C.) para justificar o desuso da lex commissoria antes de sua proibição oficial. Isso porque o primeiro referer-se-ia exclusivamente à lex commissoria em matéria de venda, enquanto o segundo apenas traria a determinação de que, em caso de inadimplemento, a facultas distrahendi deva ser devolvida segundo a prática ordinária ("...communi iure...").

${ }^{454}$ Cf. V. LOJACONO, Il patto commissorio cit. (nt. 204 supra), p. 12.

$455 \mathrm{O}$ princípio da inderrogabilidade das normas de ius publicum por acordo privado das partes implicava na nulidade de qualquer disposição de vontade contrária às leis ou aos bons 
Acolhido por Justiniano em seu Codex ${ }^{456}$, sob o título "De pactis pignorum et de commissoria lege in pignoribus rescindenda" ${ }^{1457}$, o texto foi reproduzido com duas mudanças bastante polêmicas: à expressão "legis commissoriae" acrescentou-se a forma declinada, também no genitivo, "pignorum" e o verbo recipere foi substituído por recuperare.

Por essa razão, a leitura conjunta de ambos os fragmentos poderia gerar incertezas sobre:

a) O exato alcance de "pignorum", que, em resumo, poderia se referir apenas ao penhor ou a outras formas de garantias reais (mais precisamente à hipoteca);

b) A eventual existência de alguma importante diferença semântica entre recipere e recuperare que possa influenciar a interpretação da regra proibitória.

Desde logo, exclui-se qualquer polêmica relacionada a este último item. Isso porque o recipere utilizado por Constantino nada mais é do que uma forma arcaica de recuperare ${ }^{458}$. Trata-se de mera adequação lexicológica à época do segundo texto que nenhuma influência poderia ter sobre seu conteúdo.

Por outro lado, ponto suscetível de maiores controvérsias foi a inserção da matéria, ainda no Codex Theodosianus, imediatamente após o título dedicado à “de contrahenda emptione” (C. Th. 3, 1). A proximidade das colocações fez com que fosse levantada ${ }^{459}$ a discutível hipótese de que a proibição também se

costumes ("Pacta quae contra leges constituciones que vel contra bonos mores fiunt nullam vim habere, indubitati iuri est") - cf. Ant., C. 2, 3, 6 (de 213, d.C.).

${ }^{456}$ Como veremos adiante, a adoção da proibição pelo Codex de Justiniano explicaria uma série de interpolações - cf., e.g., Marc. sing. ad form. hypoth., D. 20, 1, 16, 9 e Scaev. 7 dig., D. 18, 1, 81 pr. Nesse sentido - cf., . BISCARDI, La lex commissoria cit. (nt. 22 supra), p. 234.

${ }^{457}$ No Código Teodosiano, a rubrica diz apenas de commissoria rescindenda, o que não é tão incomum, já que também em outros fragmentos não é utilizada a palavra lex - cf., e.g., Ulp. 32 ad ed., D. 18, 3, 4, 2 ( "...utrum commissoriam velit exercere an potius pretium petere, nec posse, si commissoria elegit... "); Ulp. 32 ad ed., D. 18, 3, 4, 3 ("In commissoriam etiam hoc solet convenire...); Ulp. 32 ad ed., D. 18, 3, 4, 4 (“...commissoria utrum tunc locum habet... ”); Ulp. 32 ad ed., D. 19, 1, 13, 26 (“... diversamque causam commissoriae esse ait... ”), Ulp. 71 ad ed., D. 43, 24, 11, 13 ( “...et si forte commissoria venierit... ”).

${ }^{458}$ Cf., entre outros, F. GAFFIOT, Recupero, in Dictionnaire Latin Français, Paris, Hachette, 1934, p. 1323.

${ }^{459}$ Cf. E.Albertario, Sulla nullità cit. (nt. 359 supra), p. 234; H. DernBurg, Das Pfandrecht cit. (nt. 216 supra), pp. 273 e ss. 
estenderia aos casos de lex commissoria acessória aos contratos de compra e venda.

Nesse sentido, o acréscimo de "pignorum" por Justiniano poderia ser considerado verdadeira inovação em relação à original decisão de Constantino, ao restringir o alcance da regra a apenas um dos tipos de pacto.

No texto justinianeu, obviamente, o fato de à lex commissoria sobre a venda ter sido dado um inteiro título no Digesto ${ }^{460}$ já afastaria, por si só, quaisquer dúvidas quanto à irradiação dos efeitos da proibição expressa no Codex se dar, exclusivamente, na lex commissoria acessória aos direitos reais de garantia ${ }^{461}$.

No entanto, parece mais adequado entender a posição da proibição entre os títulos dedicados à compra e venda considerando a possibilidade de que a lex commissoria pignoribus, a exemplo do que ocorre com o análogo pacto trazido em D.18.3, pudesse se configurar como uma compra e venda sob condição.

Prova disso seria a palavra creditores na frase final ${ }^{462}$ do texto de Constantino, em uma clara referência à aplicação do instituto ao regime de $\operatorname{garantias}^{463}$. A precisa indicação "commissoriae pignorum legis" como excludente do regime da venda no Codex de Justiniano, portanto, tem função meramente pleonástica.

Resta saber, então, se, além da reafirmação da lex commissoria em matéria de garantias, ainda que sem uma real necessidade de cunho prático, a inserção de pignus ao texto visou justificar: (a) a exclusão de todas as outras formas de garantias reais, em detrimento do penhor ou (b) a extensão da medida, através da acepção mais genérica do termo, a outras formas de garantias reais, e não apenas ao penhor.

\footnotetext{
${ }^{460}$ Cf. D. $18,3$.

${ }^{461}$ Nesse sentido - cf. C. M. BIANCA, Il divieto cit. (nt. 444 supra), p. 88.

${ }^{462}$ Em sua última parte, aos credores é garantida a possibilidade de uma actio in personam caso venham a sofrer prejuízos - cf. C. M. BIANCA, Il divieto cit. (nt. 444 supra), p. 18.

${ }^{463}$ Cf., nesse sentido, V. LoJACONO, Il patto commissorio cit. (nt. 204 supra), p. 10; C. M. BIANCA, Il divieto cit. (nt. 444 supra), p. 88.
} 
A questão, quando levantada pela doutrina ${ }^{464}$, não costuma levar a conclusões diversas daquela apresentada pela segunda hipótese (b).

Para uma melhor percepção do raciocínio comumente adotado, deve-se ter em conta, em um primeiro momento, que duas são as principais acepções trazidas pelas fontes quanto à palavra pignus ${ }^{465}$ : de modo geral, seu alcance semântico pode corresponder tanto à coisa dada em garantia, quanto ao liame jurídico que visa garantir uma obrigação por intermédio de uma res.

Quanto ao objeto do negócio pignoratício, as fontes trazem expressões como "pignus capere", "pignus auferre", "pignus accipere" e, ainda, considerando a relação estabelecia com o polo antagônico, "pignus dare", "pignus tradere" e "pignus ponere" 466 .

Já no que diz respeito ao liame jurídico que estabelece a garantia, é importante lembrar que, no direito romano, o penhor e a hipoteca eram institutos bastante semelhantes, aplicando-se indistintamente às coisas móveis e imóveis, mancipi ou nec mancipi ${ }^{467}$. Aliás, tantos eram os pontos de tangência entre os dois

${ }^{464}$ Cf., especialmente, V. LoJACONO, Il patto commissorio cit. (nt. 204 supra), p. 11; O. Breglia, Patto commissorio cit. (nt. 444 supra), p. 6; A. BISCARDI, Le garanzie, cit. (nt. 205 supra), p. 587; A. BURDESE, “Lex commissoria” cit. (nt. 26 supra), p. 21.

${ }^{465}$ Cf., nesse sentido, A. Berger, Pignus, in Encyclopedic dictionary cit. (nt. 18 supra), p. 630; H.G.HeumanN-E.SeCKEl, Pignus, in Handlexikon cit. (nt. 18 supra), p. 397; A. MANIGK, Zur geschichte cit. (nt. 258 supra), p. pp. 5 e ss.; P. E. HuSCHKE, Iurisprudentiae anteiustinianae quae supersunt - in usum máxime accademicum, $5^{\mathrm{a}}$ ed., Leipzig, Teubner, 1886, pp. 716-717. Sobre o arcaísmo do termo - cf., especialmente, A. BISCARDI, Le garanzie, cit. (nt. 205 supra), p. 587 .

Por outro lado, em geral, pode-se constatar que pignus é usado nas fontes literárias nas mais diversas acepções, porém, em um sentido pouco técnico - cf., especialmente, N. HERZEN, Origine de l'hypothèque cit. (nt. 26 supra), pp. 15 e ss.; A. MANIGK, Pfandrechtliche Untersuchungen cit. (nt. 258 supra), pp. 5 e ss.; E. VolKMAR, Pignus, in VIR cit. (nt. 18 supra),pp. 201-204. Dos fragmentos literários, no entanto, não há indícios sobre a estrutura originária do instituto - cf. A. BURDESE, "Lex commissoria” cit. (nt. 26 supra), p. 21.

${ }^{466}$ Scaev. 16 dig., D. 32, 34 pr.; Mod. 5 reg., D. 20, 1, 24; Gai. 21 ad ed. prov., D. 12, 1, 28; Paul. 5 ep. Alf. dig., D. 12, 6, 36; Pomp. 6 ad Sab., D. 13, 7, 2; Paul. 29 ad ed., D. 13, 7, 20 pr; Pomp. 35 ad Sab., D. 20, 4, 4; Af. 8 quaest., D. 20, 4 , 9; Ulp. 29 ad Sab., D. 21, 2, 21, 1; Pap. 20 quaest., D. 20, 1, 3 pr.

${ }^{467}$ Cf. A. BISCARDI, Le garanzie, cit. (nt. 205 supra), p. 207. No entanto, para o autor, é provável que, em origem, o penhor tenha tido por objeto exclusivamente res nec mancipi móveis, como medida alternativa às formalidades exigidas pela fiducia cum creditore no ato de transferência da propriedade. Isso seria reforçado pelo fragmento do Digesto em que se lê "'pignus`appellatum a pugno, quia res, quae pignori dantur, manu traduntur..." - cf. Gai. 6 ad leg. duod. tab., D. 50, 16, 238, 2. 
institutos, que, ao menos no direito clássico, são igualmente designados pelo substantivo pignus (datum, para o penhor, obligatum, para a hipoteca) ${ }^{468}$.

Em outras palavras, conforme a relação implique ou não na transferência da posse antes da extinção da obrigação principal, pode o termo ser designado na forma de uma datio (pignus datum) ou na forma de uma conventio (pignus conventum ou, posteriormente, hypotheca).

Este último caso é trazido em expressões como "pignori obligare", "pignori ponere" e "pignori accipere", ou também em "pignus contrahere" e "pignoris iuri" ${ }^{469}$. Esses sentidos se contrapõem àqueles alcançados pelo penhor em sentido estrito, apresentado através de construções como "pignori dare" e "pignori tradere" 470 .

É interessante notar que, em algumas hipóteses, o mesmo verbo pode ser utilizado para se referir a um ou outro sentido, a depender da forma como o substantivo é declinado.

É o que ocorre, e.g., com "pignori accipere" e "pignus accipere", referindo-se este último à coisa que forma o objeto da relação. Do mesmo modo, em "pignus tradere" e "pignori tradere" o substantivo pode assumir dois significados bastante distintos, conforme se utilize o acusativo ou o dativo.

Apenas no direito justinianeu é que se passa a indicar com pignus o penhor manual (Faustpfand, Besitzpfand) e com hypotheca o penhor convencional $(\text { Vertragspfand })^{471}$. No entanto, também a legislação tardia demonstra que a estrutura jurídica dos dois institutos pouco se diferencia, sendo que "inter pignus et hypothecam tantum nominis sonus differt" ${ }^{472}$.

${ }^{468}$ Cf. Ulp. 40 ad Sab., D. 13, 7, 1 pr. Sobre a transição da terminologia pignus para hypotheca - cf. A. MANIGK, Pfandrechtliche Untersuchungen cit. (nt. 258 supra), pp. 15-18.

${ }^{469}$ Mod. 4 resp., D. 13, 7, 39; Ant., C. 8, 25, 2 (de 208 d.C.); Gai, sing. ad form. hypoth., D. 20, 1, 4 ; Pap. 20 quaest., D. 20, 1, 3 pr.; Pap. 11 resp., D. 20, 4, 3, 2; Ulp. 35 ad ed., D. 27, 9, 3, 1; Scaev. 6 dig., D. 20, 2, 10; Sev., C. 8, 18, 1 pr (de 209 d.C.).

${ }^{470}$ Ulp. 28 ad ed., D. 13, 6, 5, 12; Ulp. 40 ad Sab., D. 13, 7, 1, 2; Ulp. 28 ad ed., D. 13, 7, 11, 7; Iav. 3 ex post. Labeo., D.22, 1, 49; Iav. 3 ex post. Labeo., D. 50, 17, 72.

${ }^{471}$ Cf. E. Albertario, Sulla nullità cit. (nt. 359 supra), p. 234. Nesse sentido - cf. Marc. sing. ad form. hypoth., D. 20, 4, 12 pr.; Scaev. 19 dig., D. 32, 38 pr.; Paul. 45 ad ed., D. 50, 1, 5, 1; Iul. 44 dig., D. 41, 3, 33, 4.

${ }^{472}$ Cf. Marc. sing. ad form. Hypoth. D. 20, 1, 5, 1. 
Ademais, se, por pignus, a regra trazida em Const., C. 8, 34, 3 (de 326 d.C.) procurou designar, igualmente, o penhor e a hipoteca, não seria absurdo conceber que também à anticrese ela foi endereçada. Isso porque, somada à lex commissoria, a possibilidade de retenção dos frutos por parte do credor implicaria um ônus muito mais difícil de ser suportado pelo devedor do que aquele apresentado pelo penhor sob as mesmas condições ${ }^{473}$.

\subsubsection{EXEGESE DE MARC. SING. AD FORM. HYPOTH., D. 20, $1,16,9$}

Em Marc. sing. ad form. hypoth., D. 20, 1, 16, 9 é trazido um interessante caso em que, em virtude da proibição, converteu-se a lex commissoria em uma modalidade condicional de venda ${ }^{474}$ da coisa dada em garantia.

Marcianus libro singulari ad formulam hypothecariam, D. 20, 1, 16, 9:

\begin{tabular}{|c|c|}
\hline $\begin{array}{l}\text { Potest ita fieri pignoris datio } \\
\text { hypothecaeve, ut, si intra certum tempus } \\
\text { non sit soluta pecunia, iure emptoris } \\
\text { possideat rem iusto pretio tunc } \\
\text { aestimandam: hoc enim casu videtur } \\
\text { quodammodo condicionalis esse venditio. } \\
\text { Et ita divus Severus et Antoninus } \\
\text { rescripserunt. }\end{array}$ & $\begin{array}{l}\text { A entrega de < uma coisa dada a título de> } \\
\text { penhor ou de hipoteca pode fazer-se de } \\
\text { modo, que, se dentro de certo tempo não } \\
\text { tenha sido entregue o preço, por direito do } \\
\text { comprador <,ele, o comprador> possua a } \\
\text { coisa pelo justo preço a ser então estimado: } \\
\text { porque neste caso parece de certo modo que } \\
\text { já há uma venda condicional. E assim o } \\
\text { responderam por rescrito Divino Severo e } \\
\text { Antonino. }\end{array}$ \\
\hline
\end{tabular}

${ }^{473}$ Cf. V. Lojacono, Il patto commissorio cit. (nt. 204 supra), p. 11; O. BregliA, Patto commissorio cit. (nt. 444 supra), p 6.

474 Contra, A. MANIGK, que fala de uma cautio commissoria ao invés de venda - cf. Pfandrechtliche Untersuchungen cit. (nt. 258 supra), p. 103. No entanto, o entendimento, que é bastante minoritário, já se encontra completamente superado - cf. A. BURDESE, "Lex commissoria” cit. (nt. 26 supra), p. 120. 
Pelo fragmento de Marciano tem-se que, nos casos de penhor ou hipoteca ("...pignoris datio hypothecaeve... "), verificado o inadimplemento ("...si intra certum tempus non sit soluta pecunia... "), é lícito ao credor ficar com a coisa dada em garantia ("...iure emptoris possideat rem... "), desde que a esta seja estimado um preço justo ("...iusto pretio tunc aestimandam... ").

A provável interpolação ${ }^{475}$ presente em "iusto pretio tunc aestimandam" ${ }^{476}$ tem sua razão de ser justamente na proibição de Constantino ${ }^{477}$. Como, ao tempo do jurisconsulto clássico, o pacto comissório não era proibido ${ }^{478}$, podia-se pactuar que, caso o devedor não efetuasse o pagamento dentro de uma certa data, ao credor fosse facultado apropriar-se da coisa iure emptoris.

No entanto, uma vez difundida a mencionada proibição, dois teriam sido os caminhos possíveis à escolha dos compiladores para harmonizar o texto com aquele da constituição imperial reproduzida no $\operatorname{Codex}^{479}$ : declarar nulo o conteúdo do fragmento ou adequá-lo à ulterior regra, o que foi feito com a inserção das palavras "iusto pretio tunc aestimandam".

Quanto à expressão, o pensamento dominante ${ }^{480}$ é de que, embora possam ser apontadas algumas situações já no direito clássico em que o preço é oposto a outros modos de avaliação de uma res $^{481}$, o termo "iustum pretium" deve ser atribuído a um período mais tardio, com os compiladores justinianeus ${ }^{482}$.

475 Cf. E. Albertario, Iustum pretium e iusta aestimatio, in BIDR 311 (1920), p. 4; E. Costa, Sul papiro cit. (nt. 203 supra), p. 4; C. M. BIANCA, Il divieto cit. (nt. 444 supra), p. 87; O. LeNel (Pal. Marc. 649); Cf. N. CIPRIANI, Patto commissorio cit. (nt. 256 supra), p.11; A. BURDESE, “Lex commissoria” cit. (nt. 26 supra), p. 120.

A expressão "iusto pretio tunc aestimandam", de fato, adequa-se ao pensamento justinianeu - cf., especialmente, Nov. 120, 6, 2 (a. 544) ("... iusta et districta aestimatione facta...").

${ }^{476}$ Semelhante construção sobre a necessidade de que sejam estabelecidos critérios para o preço da coisa é trazida em uma passagem de Paulo em F. V. 9, posteriormente ratificada por Trifonino em Trif. 8 disp., D. 20, 5, 12 pr.

477 Cf. E. AlberTARIO, Sulla nullità cit. (nt. 359 supra), p. 235.

478 Também não se acredita que houvesse qualquer proibição prática antes da legislação de Constantino - cf. E. Costa, Sul papiro cit. (nt. 203 supra), p. 4.

479 Cf. E. Albertario, Sulla nullità cit. (nt. 359 supra), p. 235.

${ }^{480}$ Cf. A. GuARINO, Diritto cit. (nt. 281 supra), p. 898.

${ }^{481}$ Cf. M. TALAMANCA, Vendita in generale (diritto romano), in ED 46 (1993), p. 368. O exame das fontes anteriores a Diocleciano e Maximiniano revela casos em que a diferença entre o preço convencionado e aquele de mercado induzia, em concurso com outros elementos, à invalidade do negócio. É o que se constata, e.g., em Iav. 3 ex Cass., D. 5, 3, 48; Ulp. 15 ad ed., D. 
Foi apenas a partir deste momento que pôde ele ser entendido como o correspondente aproximativo do valor real da coisa no momento em que celebrado o contrato $^{483}$. A exigência de similar medida, dentro outras funções, teve por destaque justamente o intuito de proteger o devedor, como se verifica na hipótese apresentada em Marc. sing. ad form. hypoth., D. 20, 1, 16, $9^{484}$.

Além da estimação da coisa entregue a título de penhor ou hipoteca, é curioso notar, que, em relação aos contratos de compra e venda, apenas observouse obrigatoriedade do "iustum pretium" quanto às vendas fiscais ${ }^{485}$. Isso demonstra que, assim como as construções do "verum pretium" e do "certum pretium", foi o "iustum pretium" ${ }^{486}$ requisito exigido em situações específicas da prática contratual romana, não tendo, porém, chegado a constituir regra de aplicação geral e irrestrita.

Apenas para que melhor se esclareça a diferença terminológica, temse que enquanto o "certum pretium" refere-se à obrigatoriedade do objeto da prestação ser determinado ou determinável ${ }^{487}$, o "verum pretium", por sua vez, se presta a ressaltar a seriedade da disposição de interesses das partes, bem como a delimitação da compra e venda de outros suportes fáticos, sobretudo da doação ${ }^{488}$.

À condição de que a transferência da propriedade se opere "si intra certum tempus pecunia soluta non sit ", assim, é acrescido um novo requisito: a

5, 3, 13, 4; Ulp. 15 ad ed., D. 5, 3, 13, 5 e Paul. 62 ad ed., D. 42, 8, 7; Ulp. 44 ad ed., D. 38, 5, 1, 12; Ulp. 44 ad ed., D. 38, 5, 1, 15.

Assim, pode-se afirmar que a necessidade de correspondência entre o valor da mercadoria e o preço de aqisição não foi desconhecida ao pensamento jurídico clássico dos romanos.

${ }^{482}$ Cf. E. AlberTARIO, Iustum Pretium cit. (nt. 475 supra), pp. 1-19. No mesmo sentido, V. ARANGIO-RUIZ, La compravendita cit. (nt. 105 supra), pp. 142-148. Contra, M. K. VISKY, Appunti sulla origine della lesione enorme, in IURA 12, 1961, pp. 56-57; P. S. LEICHT, Laesio enormis e iustum pretium, in Studi di Storia e Diritto in onore di Carlo Calisse, Milano, Giuffrè, 1940, p. 46.

${ }^{483}$ Cf. A. GuARINo, Diritto cit. (nt. 281 supra), p. 898; Eliane MADEIRA, "Laesio Enormis" (tese de doutorado), São Paulo, FADUSP, 1998, p. 33. Contra: V. ARANGIO-RUIZ, La compravendita cit. (nt. 105 supra), p. 142; A. De SENARCLENS, La maxime "pretium debet esse verum, certum, iustum", in Mélanges Paul Fournier, Paris, Sirey, pp. 696-699.

${ }^{484}$ Cf. Eliane MADEIRA, "Laesio Enormis" cit. (nt. 483 supra), p. 34. No mesmo sentido, quanto ao pactum de distrahendo - cf. Philip., C. 8, 40, 18 (de 244 d.C.).

${ }^{485}$ Cf. Eliane MADEIRA, "Laesio Enormis" cit. (nt. 483 supra), p. 34.

${ }^{486}$ Sobre as relações dos três - cf. EliANE MADEIRA, "Laesio Enormis" cit. (nt. 483 supra), pp. 21 e ss.

${ }^{487}$ Cf. V. ARANGiO-RuIZ, La compravendita cit. (nt. 105 supra), p. 138. No mesmo sentido - cf. Ulp. 28 ad Sab., D. 18, 1, 7, 1; Ulp. 32 ad ed., D. 19, 1, 13, 24; Ulp. 3 disput., D. 18, 1, 37.

${ }^{488}$ Cf. M. Talamanca, Vendita cit. (nt. 481 supra), p. 364; V. Arangio-RUIZ, La compravendita cit. (nt. 105 supra), p. 142. 
determinação de um preço justo por um terceiro desinteressado. Aqui se encontra justamente a origem do pacto marciano ${ }^{489}$.

É importante notar que, a exemplo da lex commissoria, também é este pacto uma convenção acessória que importa, em caso de inadimplemento da obrigação garantida, na transferência definitiva ao credor do bem entregue em garantia.

As duas convenções se diferenciam, todavia, em um aspecto fundamental. Enquanto a lex commissoria tem por efeito a extinção da obrigação garantida tão logo seja a transferida a propriedade , o pacto marciano subordina a aquisição pelo credor à prévia avaliação econômica do bem por parte de um terceiro, imediatamente após o inadimplemento ${ }^{490}$.

Consequentemente, definido o valor do bem em relação ao montante do débito restante, é dado o credor à restituição da eventual diferença, caso venha a se beneficiar com o superfluum, ou lhe é facultada a compensação do que deixou de receber, caso tenha sido insuficiente a quantia obtida com a venda. Até que isso ocorra, a obrigação apenas parcialmente se extingue ${ }^{491}$.

Além disso, ao aceitar a mencionada interpolação relativa ao preço, não seria absurdo deduzir que a proibição do pacto comissório é geral: diz respeito aos casos em que a garantia real foi prestada com e àqueles em que foi prestada sem transferência da posse. Caso contrário, não haveria razão no silêncio dos compiladores a respeito de uma tão importante limitação à regra ${ }^{492}$.

489 Por se tratar de instituto bastante tardio, o estudo do pacto marciano, em regra, costuma ser aliado ao do pacto comissório, sendo quase inexistentes monografias específicas. Nesse sentido, para sua melhor compreensão, preciosos acabam sendo também alguns poucos trabalhos de direito civil que cuidam do tema de modo mais apurado - cf. N. CIPRIANI, Patto commissorio cit. (nt. 256 supra), pp. 11 e ss.; G. F. MINNITI, Patto marciano e irragionevolezza del disporre in funzione di garanzia, in Rivista di diritto commune I, 1997, p. 29 e ss. Entre as várias reconstruções, v., em particular, M. C. DE CICCO, Il divieto del patto commissorio, in L. Ferroni (a cura di), Le nullità negoziali, Milano, 1998, pp. 486 e ss.

490 Cf. N. CiPRIANI, Patto commissorio cit. (nt. 256 supra), p. 11.

491 Cf. N. Cipriani, Patto commissorio cit. (nt. 256 supra), p. 11. Segundo o autor, por superar as limitações à validade do pacto comissório, o pacto marciano começou a difundir-se justamente quando o pacto comissório foi vedado - cf. N. CIPRIANI, Patto commissorio cit. (nt. 256 supra), p. p. 12. No entanto, não há em outros autores ou fontes consultadas qualquer refistro de que a prática do pacto marciano fosse comum antes de Justiniano.

492 Cf. E. Albertario, Sulla nullità cit. (nt. 359 supra), p. 236. 
Outra expressão ao longo do fragmento de Marciano que costuma suscitar mais dúvidas quanto à sua genuidade 493 é "videtur quodammodo", que denota uma aparente incerteza ao qualificar a hipótese como uma venda condicional $^{494}$. Novamente, A. BURDESE e A. BISCARDI divergem sobre a questão - desta vez sem que, no entanto, sejam apresentados argumentos realmente consistentes por quaisquer deles.

Para A. BURDESE ${ }^{495}$, já Marciano teria previsto a possibilidade de uma iure emptoris possidere em detrimento do ainda válido pacto comissório. Se correto, duas importantes consequencias seriam intrínsecas a seu pensamento:

a) não haveria razão para acreditar em uma interpolação de "iusto pretio tunc aestimandam" - ou ao menos que esta tenha se dado em virtude da proibição da lex commissoria ${ }^{496}$;

b) o fragmento comprovaria que, antes mesmo de sua proibição, a aplicação prática da lex commissoria teria sido preterida pela de outros meios acessórios de satisfação do crédito, como é o caso venda condicional ${ }^{497}$.

A escassez de fontes que possam comprovar tais argumentos torna a tese de A. BISCARDI ${ }^{498}$ mais verossímil. Para o autor, nos casos de penhor, em que a traditio da coisa é imediata, os efeitos trazidos por um pacto que visasse transferir a propriedade ao credor seriam análogos aos de um contrato de compra e venda incondicionado. A incerteza trazida por "videtur quodammodo" abrangeria, portanto, essa situação excepcional em que a venda é pura - ainda que resolúvel.

493 Nesse sentido - cf. S. RICCOBONO, Studi critici sulle fonti del diritto romano, in BIDR 8 (1895), p. 173.

494 Contrariamente, segundo alguns autores mais antigos, a incerteza do jurisconsulto referia-se à possibilidade de que se tratasse de venda incerti pretii - cf., entre outros, J. J. BACHOFEn, Das römische Pfandrecht cit. (nt. 216 supra), pp. 621 e ss.; H. DERnBURG, Das Pfandrecht cit. (nt. 216 supra), p. 284. A ideia, embora hoje refutada, não é de todo absurda, na medida que o certum pretium é justamente um requisito findamental para a eficácia da compra e venda consensual em função de garantia - cf. A. BISCARDI, Le garanzie, cit. (nt. 205 supra), p. 220.

495 Cf. A. BURDESE, “Lex commissoria” cit. (nt. 26 supra), p. 121.

496 E, nesse sentido, haveria uma contradição com a propria linha de pensamento do autor, aberto defensor da interpolação - cf. A. BuRdESE, "Lex commissoria” cit. (nt. 26 supra), p. 120.

497 Não há, nas fontes, qualquer menção a situação semelhante.

498 Cf. A. BISCARDI, Le garanzie, cit. (nt. 205 supra), pp. 583-584. 
Ao lado de Marc. sing. ad form. hypoth., D. 20, 1, 16, 9, é costumeiramente analisado Scaev. 7 dig., D. 18, 1, 81 pr., que traz um importante entendimento de Cévola relativo ao pactum displicentiae.

Neste fragmento, que abre o livro que trata da compra e venda em sua obra Digestorum ${ }^{499}$, questiona-se se os bens dados em garantia ("...dedit pignori sive hypothecae praedia ... ") poderiam passar à propriedade do fiador que tivesse quitado a dívida com os credores da obrigação principal ("Quaero, cum non sit liberatus Lucius fideiussor a Titio, an, si solverit creditori, empta haberet supra scripta praedia ..." ").

Com a extinção da obrigação principal pelo adimplemento, a relação acessória representada pela garantia pessoal da fiança assumiria o primeiro plano, passando o fiador à posição de credor. A peculiaridade de ter sido instituída uma concomitante garantia real levantou a eventual possibilidade de que, instituída a lex commissoria, pudessem seus efeitos serem estendidos também àqueles que não seriam parte no liame pignoratício propriamente dito ${ }^{500}$.

Para responder a essa questão, é importante que se atente à expressão final "contractam esse obligationem", cujo alcance semântico tornou-se polêmico a partir da exposição de A. MANIGK, apresentada na obra clássica Pfandrechtliche Untersuchungen ${ }^{501}$. Para o autor, que não fundamenta sua posição, o termo obligatio indicaria a obligatio pignoris.

A tese foi bastante criticada por seus principais opositores ${ }^{502}$ por ser contraditória à anterior expressão "si non ut in causam obligationis, sed ut empta habeat", que emprega o mesmo termo para tratar da venda. Ali, a qualificação da venda condicional parece depender da escolha de que seja estipulada uma venda ao invés de um vínculo de garantia ${ }^{503}$.

499 Cf. O. LENEL (Pal. Scaev . 223).

500 Cf. C. M. BIANCA, Il divieto cit. (nt. 444 supra), p. 87.

${ }^{501}$ Cf. Untersuchungen cit. (nt. 258 supra), p. 106; H. DERnBURG, Das Pfandrecht cit. (nt. 216 supra), p. 284.

${ }_{502}$ Cf., especialmente E. RABEL, Nachgeformte Rechtsgeschäfte in ZRG 28 (1907), p. 363 e A. BuRDESE, “Lex commissoria” cit. (nt. 26 supra), p.122.

503 Cf. C. M. BIANCA, Il divieto cit. (nt. 444 supra), p. 87. 
Assim como em Marc. sing. ad form. hypoth., D. 20, 1, 16, 9, portanto, o fragmento apresenta uma questão condicionada ao arbítrio das partes: a emptio sub condicione dos bens ocorre simplesmente porque a vontade daqueles que a instituem é no sentido da venda e não da entrega da coisa ao credor a título de garantia ${ }^{504}$.

Em outras palavras, a impossibilidade de que às garantias seja inserida a lex commissoria, reduz a solução do problema ao elemento volitivo, genericamente dirigido a uma alienação in causam obligationis ${ }^{505}$. Não sendo pactuado o ius vendendi, ainda restava ao credor a possibilidade de adquirir a coisa iure empti, ou seja, através de uma compra e venda ${ }^{506}$.

Isso foi suficiente para que A. BISCARDI ${ }^{507}$ entendesse estar provado que a proibição de Constantino teria se referido, na verdade, a um instituto grego e não romano. Isso porque a lex commissoria romana, que supostamente teria a mesma configuração para a venda e para as garantias reais, continuaria a ser aplicada através da modalidade supramencionada ${ }^{508}$.

Para tanto, no entendimento do autor, a lex commissoria nada mais seria do que uma cláusula convencional que se resolve em um contrato condicionado de compra e venda e, sob tal configuração, estaria presente em Marc. sing. ad form. hypoth., D. 20, 1, 16, 9 e Scaev. 7 dig., D. 18, 1, 81 pr $^{509}$. Sua teoria, porém, não explica como poderia subsistir tal construção diante da inexigibilidade de fixação de preço nas relações reais às quais se aplica o pacto.

504 Cf., nesse sentuido, G. PUGLIESE, La simulazione cit. (nt. 71 supra), p. 172.

505 Cf. C. M. BIANCA, Il divieto cit. (nt. 444 supra), p. 87, para o qual a distinção não teria sentido se a lex commissoria fosse ela mesmo uma venda condicional.

506 Cf. C. M. BIANCA, Il divieto cit. (nt. 444 supra), p. 87; A. BISCARDI, Le garanzie, cit. (nt. 205 supra), p. 231.

507 Cf. A. BISCARDI, Le garanzie, cit. (nt. 205 supra), p. $588 .$.

508 A hipótese é bastante absurda, não só pela s evidentes diferenças entre a lex commissoria na venda e nos direitos reais mencionadas ao longo deste trabalho, como também pela própria configuração da lex commissoria no direito grego, cujas peculiaridades foram brevemente levantadas alhures - cf. item II.1.2.3.

509 Contra - cf. C. M. BIANCA, Il divieto cit. (nt. 444 supra), p. 87. A. BuRdESE, "Lex commissoria” cit. (nt. 26 supra), pp. 124-125. Para este último, também a venda da garantia sob condição, como pacto análogo à lex commissoria, teria entrado sob a proibição de Constantino, como demonstraria, de fato, a interpolação relativa ao preço. 
Afastada a tese de A. MANIGK, para E. RABEL ${ }^{510}$, tendo por premissa que uma suposta interpolação em "pignori sive hypothecae" substituiu a menção ao negócio fiduciário, a configuração dada ao caso seria híbrida: Cévola teria reconhecido a venda, mas atribuído ao comprador as obrigações do fiduciário. Tratar-se-ia, então, originariamente de uma obligatio fiduciae.

Apesar de o fragmento não contar com qualquer elemento que permita semelhante conexão ao negócio fiduciário, a tese vigorou por longo período ${ }^{511}$ até uma melhor solução ser levantada por A. BURDESE.

Segundo o autor" ${ }^{512}$, é mais provável que a expressão "contractam esse obligationem" seja, na verdade, a forma resumida de um discurso mais longo sobre a incumbência do comprador de pagar o preço, a exemplo do que ocorre em Marc. sing. ad form. hypoth., D. 20, 1, 16, 9 e também em F.V. $9^{513}$.

\footnotetext{
${ }^{510}$ Grundzüge cit. (nt. 243 supra), p. 363.

511 No mesmo sentido - cf. W. ERBE, Die Fiduzia cit. (nt. 26 supra), p. 10.

512 “Lex commissoria” cit. (nt. 26 supra), pp. 122-123.

513 Cf. nt. 476 supra.
} 


\section{OS ATUAIS LIMITES DA PROIBIÇÃO DO PACTO COMISSÓRIO ÀS GARANTIAS REAIS TÍPICAS}

\section{A CONFIGURAÇÃO DA PROIBIÇÃo NAS MODERNAS} CODIFICAÇÕES ${ }^{514}$

O CC/02 trouxe a proibição do pacto comissório ${ }^{515}$ em seus artigos 1.365 e 1.428, ao tratar das garantias reais tradicionais e da alienação fiduciária em garantia. Esta última, aliás, representou importante inovação em relação ao CC/16, que apenas deu disciplina específica ao penhor, à hipoteca e à anticrese ${ }^{516}$.

Antes, porém, de passar à análise do instituto no direito pátrio, fazemse pertinentes algumas breves e superficiais considerações sobre o tratamento a ele concedido nas legislações estrangeiras. Embora nem sempre sob os mesmos fundamentos $^{517}$, os efeitos da proibição romana vista alhures estenderam-se amplamente aos ordenamentos modernos, em especial àqueles de tradição jurídica romano-germânica.

Nesses países, doravante elencados de modo apenas exemplificativo, a fim de traçar mero panorama que auxilie em uma melhor compreensão de como a proibição se apresenta hodiernamente ${ }^{518}$, pode-se didaticamente dividir o tema em três principais grupos:

${ }^{514}$ Cientes de que a mera reprodução de dispositivos legais, destacada de mais completa exegese, em regra, seja sinônimo de pobreza técnico-científica, optamos, contudo, por sua utilização, para facilitar a melhor compreensão do leitor sobre a variada forma de apresentação da regra na legislação estrangeira.

${ }^{515}$ Sobre a terminologia - cf. item II.1.1.

516 A proibição no diploma de 1916 era assim trazida em seu art. 765: "É nula a cláusula que autoriza o credor pignoratício, anticrético ou hipotecário, a ficar com o objeto da garantia, se a dívida não for paga no vencimento”.

${ }^{517}$ Cf. item III.3.

518 Neste primeiro momento não se pretende, portanto, desenvolver qualquer comparação jurídica stricto sensu. Isso porque, como se espera ter deixado claro desde sua introdução, o presente trabalho não tem a pretensão de esgotar o tema da proibição do pacto comissório no $\mathrm{CC} / 02$. Diferentemente, no tocante ao ordenamento pátrio, foram selecionadas algumas temáticas pertinentes à compreensão da aplicação da regra às garantias reais típicas, sendo que eventuais 
a) Codificações que adotam a proibição sem ressalvas.

b) Codificações em que, embora a proibição ainda seja a regra, são expressamente previstas as hipóteses de venda ou dação posteriores ao inadimplemento.

c) Codificações em que a proibição foi revogada.

Transcorridos mais de dezoito séculos desde sua oficialização, a vedação de Constantino continua sendo a regra ainda adotada por grande parte dos países de direito continental europeu e latino-americano - inclusive o nosso. No entanto, a existência desse terceiro grupo, pautado em corrente mais recente que admite a aplicação do pacto, demonstra que ela começa a sofrer erosões ${ }^{519}$.

\subsection{CODIFICAÇões QUE ADOTAM A PROIBIÇão SEM}

\section{RESSALVAS}

Na Itália, país a questionar de modo mais contundente a proibição ${ }^{520}$, o debate em relação à regra era bastante significativo já sob a égide do Código de

comentários de caráter verdadeiramente substancial acerca das legislações estrangeiras serão levantados nesses momentos oportunos.

519 A pertinente expressão é cunhada por Cf. L. G. HADDAD, A proibição do pacto comissório no direito brasileiro (tese de doutorado em Direito Civil), São Paulo, FADUSP, 2013, p. 37.

${ }^{520}$ Dentre as obras pioneiras, destaca-se a de C. M. BIANCA, Il divieto cit. (nt. 444 supra). Antes desta, porém - cf. E. BETTI, Su gli oneri e i limiti dell'autonomia privata in tema di garanzia e modificazione di obbligazioni, in Rivista del Diritto Commerciale e del Diritto Generale delle Obbligazioni, v. 24, Milano, Francesco Vallardi, 1931, pp. 689-715; F. CARnelutTI, Note sul patto commissorio, in Studi di diritto processuale, v. I, Padova, Cedam, 1928, pp. 487-492; G. MIRABELli, Diritto dei Terzi secondo il codice civile italiano, I, Torino, 1889, p. 598; G. P. CHIRONI, Trattato dei privilegi, delle ipoteche e del pegno, $2^{\mathrm{a}} \mathrm{ed}$., Milano, 1918, p. 706; B. BRUGGI, Il patto commissorio ex intervallo, in Riv. Dir. Comm., II, 1919, p. 396; V. ANDrioli, Commentario del Codice Civile a cura di Antonio Scialoja e Giuseppe Branca, libro 6, Tuttela dei diritti. Art. 2.740-2.899, Bologna, Nicola Zanichelli, 1945, pp. 49-54; D. RUBINO, La responsabilità patrimoniale. Il pegno, $2^{\mathrm{a}}$ ed., Torino, UTET, 1949, pp. 5-25; S. PUGLIATTI, Precisazioni in tema di vendita a scopo di garanzia, in Diritto civile, Metodo-teoria-pratica, Saggi, Milano, Giuffrè, 1951. Ainda sobre o tema, V. LOJACONO, Il patto commissorio cit. (nt. 204 supra), p. 13 e ss.; C. VARRONE, Il trasferimento della proprietà a scopo di garanzia, Napoli, Jovene, 1968; C. M. BIANCA, Patto commissorio (voce), in Novissimo Digesto Italiano, v. XII, Torino, UTET, 1965, pp. 711-721; U. CARNEVAli, Patto commissorio cit. (nt. 520 supra), pp. 499506; L. BARBIERA, Responsabilità patrimoniale - Disposizioni genelali, in Il Codice Civile Commentario diretto da Piero Schlesinger. Art. 2740-2744, Milano, Giuffrè, 1991, pp. 205-268; A. Luminoso, Alla ricerca degli arcani confini del patto commissorio, in Rivista di Diritto Civile, v. 36, Padova, 1990, pp. 219-242, M. G. CUBEDDU, Patto commissorio e vendita con patto di 
1.865, especialmente no que diz respeito (a) à aplicação do pacto à hipoteca e (b) à possibilidade de que fosse celebrado ex intervallo - ou seja, não antes, mas durante a vigência do contrato de garantia ${ }^{521}$.

Em relação à primeira questão, suscitada pela ausência de qualquer menção legal que restringisse a aplicação do pacto à hipoteca ${ }^{522}$, prevaleceu na jurisprudência o entendimento favorável à validade do pacto comissório aposto a tal espécie de garantia. O pacto comissório imobiliário era, desse modo, plenamente aceito nos tribunais italianos à época ${ }^{523}$.

$\mathrm{Na}$ doutrina, por outro lado, dominou a tese oposta, contrária à validade do acordo sob qualquer circunstância, por entender cabível uma interpretação analógica ao penhor e à anticrese ${ }^{524}$. As implicações práticas de semelhante construção, por óbvio, eram ainda bastante incipientes, quase especulativas, sem o devido respaldo jurisprudencial.

A tendência à tomada de posições mais flexíveis pela jusrisprudência também se reproduziu quanto ao problema do pacto comissório ex intervallo, ao

riscatto - la risposta delle sezione unite, in Rivista di Diritto Civile, v. 36, n. 5, Padova, 1990, pp. 615-630; F. ANGELONI, Sulla responsabilità disciplinare del notaio che roghi un atto contenente un presunto patto commissorio, in Contratto e Impresa, v. 16, n. 3, Padova, 2000, pp. 1086-1100; R. DE NiCTOLIS, Divieto del patto commissorio, alienazioni in garanzia e "sale-lease-back", in Rivista di Diritto Civile, v. 37, n. 5, Padova, 1991, pp. 535-569; I. RIVA, Il contratto di "sale and lease back" e il divieto del patto commissorio, in Contratto e Impresa, v. 17, n. 1, Padova, 2001, pp. 300-324, M. I. BRUGI, Patto commissorio (voce), in Enciclopedia Giuridica, Roma, Istituto della Enciclopedia Italiana, 2010, pp. 1-16.

${ }^{521}$ Cf. N. CIPRIANI, Patto commissorio cit. (nt. 256 supra), p. 76.

${ }^{522}$ Por outro lado, a menção fazia-se presente em relação ao penhor e à anticrese - cf. V. LOJACONO, Il patto commissorio cit. (nt. 204 supra), p. 12; C. M. BIANCA, Patto commissorio cit. (nt. 520 supra), p. 713; U. CARnevali, Patto commissorio cit. (nt. 520 supra), pp. 500-501; A. LuMINOSO, Alla ricerca degli arcani cit. (nt. 520 supra), p. 220; F. ANGELONI, Sulla responsabilità cit. (nt. 520 supra), pp. 1088-1089.

${ }_{523}$ Inicialmente, na jurisprudência prevaleceu a opinião contrária motivada pelo fato que as razões da proibição deveriam considerar-se válidas também para a hipoteca - cf., e.g., Cass.Firenze, 02/07/1917, in Giur.it., I, 1918, pp. 500 e ss. Sucessivamente, uma decisão da Cassazione Romana torna dominante a opinião contrária, e se baseava no entendimento de que a proibição trazida pela lei, limitando a liberdade das partes, deveria ser considerada uma norma de caráter excepcional e, como tal, não poderia ser aplicada por analogia - cf. Cass.Roma, 28/07/1923, in Foro Italiano, Torino, Giappichelli,1923, pp. 935 e ss. Para um maior aprofundamento sobre as discussões doutrinárias à época - cf. N. CIPRIANI, Patto commissorio cit. (nt. 526 supra), pp. 77-79.

${ }^{524}$ Cf. E. BetTI, Su gli oneri cit. (nt. 520 supra), pp. 689-715; F. CARnELUTTI, Note sul patto commissorio cit. (nt. 520 supra), pp. 487-492; B. BRUGGI, Il patto cit. (nt. 520 supra), p. 396. 
qual era favorável ${ }^{525}$. Uma vez mais, a ela mostrou-se contrária significativa parcela da doutrina, que entendia contra legem também o pacto celebrado em momento posterior à garantia ${ }^{526}$.

A partir de 1.942, a proibição vem positivada nos artigos 2.744 e 1.963 do Codice Civile ${ }^{527}$, que, com redação bastante semelhante, tratam respectivamente do penhor e da hipoteca, e da anticrese.

No entanto, se, ao vedar absolutamente a celebração do pacto, o legislador, de um lado, resolveu as mencionadas questões tão discutidas na vigência da precedente codificação, de outro, com a consequente ampliação dos limites do tipo legal, introduziu um novo problema aos intérpretes: o de individuar o efetivo alcance da nova norma ${ }^{528}$.

Passou-se a questionar, nesse sentido, se a proibição à transferência convencional da propriedade como reforço ao contrato de garantia atingiria apenas o pacto comissório ou se também seria possível aplicá-la a qualquer outro negócio acessório de análogos efeitos. Deste assunto, no entanto, trataremos mais $\operatorname{adiante}^{529}$.

Por ora, interessa saber que, da literalidade dos dispositivos de seu código vigente, o ordenamento italiano, a princípio, sem ressalvas ${ }^{530}$, sanciona

${ }^{525}$ Cf., e.g., Cass.Torino (10/03/1887), in Foro Italiano, Torino, Giappichelli, 1887, pp. 484 e ss.; Cass.Torino (10/03/1919), in Rivista del Diritto Commerciale, Padova, Piccin, 1919, pp. 396 e ss.

${ }^{526}$ G. Mirabelli, Diritto dei Terzi cit. (nt. 520 supra), p. 598; G. P. ChIRONI, Trattato dei privilegi cit. (nt. 520 supra), 2a ed., Milano, 1918, p. 706; B. BRUGGI, Il patto cit. (nt. 520 supra), p. 396. Contra - cf. C. VIVANTE, Tratatto di diritto commerciale, v. 4, $5^{\mathrm{a}}$ ed., Milano, Fratelli, Bocca, 1926, p. 282.

527 "2.744. È nulo il patto col quale si conviene che, in mancanza del pagamento del credito nel termine fissato, la proprietà della cosa ipotecata o data in pegno passi al creditore. Il patto è nullo anche se posteriore alla costituzione dell 'ipoteca o del pegno" (= É nulo o pacto pelo qual se estabelece que, na ausência do pagamento do crédito no termo fixado, a propriedade da coisa hipoteca ou dada em penhor seja transferida ao credor. O pacto é nulo também se posterior à constituição da hipoteca ou do penhor) (tradução nossa).

"1963. È nullo qualunque patto, anche posteriore alla conclusione del contratto, con cui si conviene che la proprietà dell'immobile passi al creditore nel caso di mancato pagamento del debito" (= É nulo qualquer pacto, ainda que posterior à celebração do contrato, que estabeleça que a propriedade do imóvel seja transferida ao credor no caso de faltante pagamento do débito) (tradução nossa).

${ }^{528}$ Cf. N. CIPRIANI, Patto commissorio cit. (nt. 256 supra), p. 49.

${ }^{529} \mathrm{Cf}$. item III.2.1.

${ }^{530}$ Sobre este último ponto cabe, contudo, ressaltar que nada é dito sobre a circunstância de a dívida estar ou não vencida. Em outras palavras, a legislação toma por marco o período de 
com nulidade a convenção comissória, in continenti ou ex intervallo, nos contratos de penhor, hipoteca e anticrese.

\subsection{CODIFICAÇõeS EM QUE, EMBORA A PROIBIÇÃo AINDA SEJA A} REGRA, SÃo EXPRESSAMENTE PREVISTAS AS HIPÓTESES DE VENDA OU DAÇÃO POSTERIORES AO INADIMPLEMENTO

Em Portugal ${ }^{531}$, a proibição é trazida nos artigos 694, 678, 665 e $753^{532}$ do Código Civil de $1.966^{533}$, em relação à hipoteca ${ }^{534}$, ao penhor, à consignação de rendimentos de bens imóveis ${ }^{535}$ e simples privilégios creditórios.

constituição da hipoteca, do penhor (art. 2.744) ou da anticrese (1.963), mas é silente quanto à eventual possibilidade de celebração do pacto comissório no caso de já verificado o inadimplemento. Sobre este ponto -cf., especialmente, L. G. HADDAD, A proibição cit. (nt. 519 supra), p.40.

${ }^{531}$ Também em Portugal são escassos os trabalhos que tratem diretamente da proibição cf. I. Andrade de Matos, O Pacto Comissório, Coimbra, Almedina, 2006; J. P. ReMÉdio MARQUES, Locação financeira restitutiva (sale and lease-back) e a proibição dos pactos comissórios - Negócio fiduciário, mútuo e acção executiva, in Boletim da Faculdade de Direito da Universidade de Coimbra, v. 77, Coimbra, 2001, pp. 575-632. Mais genericamente - cf. A. Menezes CordeIro; Direitos Reais, Lisboa, Lex, 1993; M. J. AlmeIDA CostA, Alienação fiduciária em garantia e aquisição de casa própria - Notas de direito comparado, in Direito e Justiça, v. 1, n. 1, 1980, pp. 41 a 57; M. J. AlmEIDA CosTA, Penhor - Ilicitude na Guarda da Coisa Penhorada - Venda Antecipada, in Colectânea de Jurisprudência, t. 2, v. 10, 1985, pp. 1929; L. Cunha Gonçalves, Comentário ao Código Civil Português, v. 5, Coimbra, Coimbra, 1932, pp. 20 e ss.; F. A. PIRES De LiMA - J. M. ANTUNes VARElla, Código Civil Anotado, v. 1, $4^{\text {a }}$ ed., Coimbra, Coimbra, 1987, pp. 57 e ss.; J. P. FAZENDA MARTINS, Direitos reais de gozo $e$ garantia sobre valores mobiliários, in Direito dos Valores Mobiliários, Lisboa, Lex, 1997, pp. 30 e ss.; J. F. RodRIGUES BAStos, Das Obrigações em Geral - Segundo o Código Civil de 1966, v. 4, Viseu, Guerra, 1973, pp. 121 e ss.; M. I. H. MENEZES CAMPOS, Da Hipoteca - Caracterização, Constituição e Efeitos, Coimbra, Almedina, 2003, pp. 3 e ss.; A. MEnEZES CordeIRO, Direito das Obrigações, $3^{\circ}$ vol., Contratos em Especial - Compra e Venda, Sociedade, Mútuo, Mandato, Empreitada, $2^{\text {a }}$ ed., Lisboa, Faculdade de Direito de Lisboa, 1991, pp. 42 e ss.; L. A. CARVALHO FERNANDES, A Conversão dos negócios jurídicos civis, Lisboa, Quid Iuris?, 1993, pp. 84 e ss.; L. A. CARVAlho Fernandes, Lições de Direitos Reais, $4^{\mathrm{a}}$ ed., Lisboa, Quid Iuris?, 2003, pp. 134 e ss.; L. A. CARVAlho Fernandes, A admissibilidade do negócio fiduciário no direito português, in Estudos sobre a Simulação, Lisboa, Quid Iuris?, 2004, pp. 36 e ss.; J. DIAS FERREIRA, Codigo Civil Portuguez Annotado, v. 2-3, 2a ed., Coimbra, Imprensa da Universidade, 1895, pp. 267 e ss.

532 "694. É nula, mesmo que seja anterior ou posterior à constituição da hipoteca, a convenção pela qual o credor fará sua a coisa onerada no caso de o devedor não cumprir". "678. São aplicáveis ao penhor, com as necessárias adaptações, os artigos 692. ${ }^{\circ}$ 694. ${ }^{\circ}$ a 699. ${ }^{\circ}, 701 .^{\circ} e$ 702.". "665. São aplicáveis à consignação, com as necessárias adaptações, os artigos 692.", 694. " a 696. ", 701. ' e 702. ". "673. São aplicáveis aos privilégios, com as necessárias adaptações, os artigos 692. ${ }^{\circ}$ e 694. ${ }^{\circ}$ a $699 .^{\circ}$ ”.

Importa ressaltar que J. M. ANTUNES VARELLA qualifica a redação do art. 694, que traz a definição do instituto sob a epígrafe "pacto comissório" como um "princípio geral" aplicável às 
Mais recentemente, em 2003, o Decreto-lei n. ${ }^{\circ}$ 38, o art. 675 passou a figurar com a seguinte redação: "1 - Vencida a obrigação, adquire o credor o direito de se pagar pelo produto da venda executiva da coisa empenhada, podendo a venda ser feita extraprocessualmente, se as partes assim o tiverem convencionado. 2. É lícito aos interessados convencionar que a coisa empenhada seja adjudicada ao credor pelo valor que o tribunal fixar".

Com a reforma, substituiu-se o termo "extrajudicial" por
"extraprocessual"536, o que, para R. PINTO ${ }^{537}$, representou uma verdadeira

hipotecas e, por consequência, às garantias reais em geral - cf. Das obrigações em geral, v. 2, 10 ed., Lisboa, Almedina, 2000, pp 554-555.

${ }^{533}$ Embora o Código de Seabra não fizesse referência expressa à denominação "pacto comissório", como sucede no atual Código Civil de 1966, dois eram os preceitos que lhe faziam referência: um relativo ao penhor (artigo 864) e outro à hipoteca (artigo 903). Na primeira dessas disposições, previa-se que "o credor não pode ficar com o objecto do penhor, em pagamento da dívida, sem avaliação, ou por avaliação por ele feita (...)" e na segunda estabelecia-se que "o credor não pode, na falta de pagamento, apropriar-se do prédio hipotecado, excepto arrematando-o em praça ou sendo-lhe adjudicado; ma sesta arrematação ou adjudicação far-se-á sempre, seja qual for o valor do prédio e o da dívida assegurada por hipoteca, salvo se o credor consentir em outra coisa".

Como consequência da proibição do pacto comissório, a execução do penhor só podia fazer-se judicialmente ou, se assim tivesse sido convencionado, extrajudicialmente - cf. I. ANDRADE DE MATOS, O Pacto Comissório cit. (nt. 531 supra), p. 51.

${ }^{534}$ É interessante notar que nos trabalhos preparatórios do Código Civil de 1966, A. VAZ SERRA tratou do penhor de forma mais cuidadosa do que a hipoteca, cuja disciplina da proibição optou por simplesmente remeter às normas àquele relativas - cf. Penhor, in Boletim do Ministério da Justiça, n. ${ }^{\circ}$ 59, Lisboa, Gabinete de documentação e direito comparado, 1956, p. 148. No entanto, no atual Código Civil português foi utilizada a técnica inversa. Ou seja, prevê-se a proibição do pacto comissório no regime da hipoteca e depois registra-se a permissão para o art. 694 do Código Civil nas restantes garantias reais. A redação definitiva de tal artigo apenas veio a ocorrer no Projeto do Código Civil propriamente dito - cf. J. F. RODRIGUES BASTOS, Das Obrigaç̃ós em Geral - Segundo o Código Civil de 1966, v. 4, Viseu, Guerra, 1973, p. 227.

${ }^{535}$ Bastante semelhante à anticrese, a consignação de rendimentos consiste na aplicação dos rendimentos de certos imóveis sujeitos a registro à garantia do cumprimento de uma obrigação (que pode ser condicional ou futura), e do pagamento dos respectivos devidos, ou tão só do cumprimento da obrigação ou do pagamento dos juros - cf. J. P. FAZENDA MARTins, Direitos reais de gozo e garantia sobre valores mobiliários, in Direito dos Valores Mobiliários, Lisboa, Lex, 1997, p. 99.

${ }_{536}$ Apesar da discussão gerada pelo termo, a doutrina portuguesa parecia acolher pacificamente a possibilidade de se recorrer à venda extraprocessual, sem necessidade da observância de quaisquer regras específicas - cf., nesse sentido, J. A. REIS, Processo de Execução, v. 2, Coimbra, Coimbra, 1982, p. 320; F. A. Pires De Lima - J. M. ANTunes Varela, Código Civil Anotado, v. 1, $4^{\mathrm{a}}$ ed., Coimbra, Coimbra, 1987, p. 694; A. R. MENDES, O processo executivo e a economia, in Sub judice - Justiça e Sociedade, n. ${ }^{\circ}$ 2, 1992, p. 56; R. PINTO DuARTE, Curso de Direitos Reais, Principia, Cascais, 2002, p. 224; P. R. MARTINEZ - P. F. PONTE, Garantias de Cumprimento, $4^{\mathrm{a}}$ ed., Almedina, Coimbra, 2003, pp. 173-174; J. P. FAZENDA MARTINS, Direitos reais de gozo e garantia sobre valores mobiliários, in Direito dos Valores Mobiliários, Lisboa, Lex, 1997, p. 112. 
desjudicialização da venda executiva. Isso porque as vendas, que antes poderiam ser realizadas na presença ou não de um juiz, passaram a ser de responsabilidade de uma única entidade, qual seja, o agente de execução ${ }^{538}$.

Já a segunda parte, que nos é mais interessante, foi mantida pelo legislador português. Por ela, permite-se que o credor fique com a coisa pelo preço que venha a ser fixado pelo Tribunal, caso assim tenham acordado as $\operatorname{partes}^{539}$.

No que diz respeito a este último ponto, o texto representa, em certa medida, um retorno à redação das Ordenações Afonsinas - que tratavam do tema no Livro 4, Título 39, posteriormente reproduzido nas Ordenações Manuelinas (Livro 4, Título 26) e Filipinas (Livro 4, Título 56) ${ }^{540}$.

A regra geral trazida pelas ordenações reinícolas era justamente a de proibição ao pacto comissório. No entanto, admitia-se que as partes estipulassem a possibilidade de o credor ficar com a coisa empenhada pelo "justo preço", caso em que a avaliação deveria ser feita por "dous homees boõs juramentados, e escolheitos polas partes, a saber, per cada hum seu”.

${ }^{537}$ Penhora, Venda e Pagamento - Algumas Notas em Face das Alterações Impostas pelo Decreto-Lei . $^{\circ}$ 38/2003, de 8 de Março, Lisboa, Lex, 2003, p. 83.

538 Para I. ANDRADE DE MATOS, à semelhança do que ocorre em outros ordenamentos jurídicos em que os procedimentos de venda extraprocessual se encontram expressamente regulados, com o intuito precisamente de acautelar a posição do devedor, o legislador português deveria estabelecer os requisitos e trâmites aplicáveis à venda extraprocessual - cf. $O$ Pacto Comissório cit. (nt. 531 supra), p. 128.

539 Como lembra, L. G. HADDAD, embora represente uma mitigação à regra, é importante notar que o direito português não afastou a aplicação do pacto - cf. A proibição cit. (nt. 519 supra), p. 38.

É o que se verifica, e.g. no Acórdão n. ${ }^{\circ} 2.832$ do Tribunal da Relação de Coimbra, de 30 de janeiro de 2001, em que vedou-se à entidade financeira liquidar a aplicação de titularidade do devedor e, com os recursos daí decorrentes, pagar-se mediante compensação, sob pena de caracterização do pacto comissório - cf. I. ANDRADE DE MATOS, O Pacto Comissório cit. (nt. 531 supra), p. 128.

${ }_{540}$ Cf. Ordenações Filipinas, reprodução fac-simile da edição feita por Cândido Mendes de Almeida no Rio de Janeiro em 1870, Lisboa, Calouste Gulbenkian, 1985, p. 850.

Ao analisar o diploma, M. A. COELHO DA RochA destaca que a razão de ser da nulidade cominada pelo pacto comissório não está em o credor ficar com o bem empenhado, mas sim em fazê-lo sem avaliação, ou com avaliação feita por ele mesmo; se o pacto é acompanhado de ajuste sobre a realização dessa avaliação, com a participação de peritos nomeados por credor e devedor, deixa de haver razão para a invalidade - cf. Instituições de direito civil portuguez, para uso de seus discípulos. t. 2, $2^{\mathrm{a}}$ ed., Coimbra, Imprensa da Universidade, 1848, pp. 494-495. No mesmo sentido - cf. J. H. CORRÊA TELlES, Digesto portuguez ou tractado dos modos de adquirir a propriedade de a gozar e administrar e de a transferir por derradeira vontade para servir de subsídio ao novo Código Civil, t. 3, $5^{\mathrm{a}}$ edição, Coimbra, J. Augusto Orcel, 1860, pp. 193-195. 
À semelhança das regras romanas ${ }^{541}$, as Ordenações Afonsinas consideravam lícito o pacto marciano, estabelecendo a forma de se proceder à avaliação do bem dado em garantia.

Aliás, modernamente, embora o instituto seja amplamente aceito, raras são as codificações que o trazem de forma expressa. É o caso do Código argentino, que, em seu art. $3.223^{542}$, traz explicitamente a figura do mencionado pacto $^{543}$.

Assim, de um lado, o art. 3.222 do Código Civil argentino prevê a proibição do pacto comissório, ainda que o valor do bem seja inferior ao montante da dívida, e, de outro, tolera a aplicação do pacto marciano em relação ao penhor $^{544}$, como mecanismo capaz de contorná-la ${ }^{545}$.

Para tanto, sustenta a doutrina $\operatorname{argentina}^{546}$ que, diante da possibilidade de simulação, sob pena de nulidade, a ulterior avaliação pericial apenas poderia ser dispensada nos casos em que a coisa tenha um valor de mercado facilmente determinável ${ }^{547}$.

${ }^{541}$ Sobre o pacto marciano - cf. item II.3.1.2.

${ }^{542}$ A regra estende-se ainda ao artigo $8^{\circ}$ da Lei 14.005 , que trata da compra e venda de lotes a prazo (="el pacto comisorio por falta de pago, no podrá hacerse valer después que el adquirente haya abonado la parte de precio que se establece en el artículo anterior, o haya realizado construcciones equivalentes al cincuenta por ciento del precio de compra").

${ }^{543}$ Em termos semelhantes àqueles contidos no código civil argentino, a lei mexicana sanciona com nulidade o pacto comissório, entendido como aquele que autoriza o credor a se apropriar do bem empenhado, ainda que de valor inferior ao montante da dívida - cf. artigo 2.887 do Código Civil mexicano. A proibição não está expressa em relação à hipoteca, embora seja feita remissão à legislação processual para a indicação dos modos de realização dos direitos do credor hipotecário e se afirme que o credor pode adquirir o bem hipotecado em arrematação judicial - cf. artigo 2.916 do Código Civil mexicano. O mesmo art. 2.916 também é expresso a respeito da validade do pacto marciano em sede de hipoteca.

${ }^{544} \mathrm{O}$ artigo 3.252 do mesmo código, além de reproduzir a proibição do pacto comissório no âmbito da anticrese, estende expressamente a sanção de nulidade à cláusula pela qual o credor se torne proprietário do imóvel por preço fixado por peritos escolhidos de comum acordo entre as partes, ou mesmo de ofício.

${ }^{545}$ Como se extrai do teor dos artigos, a avaliação do bem deve ocorrer por ocasião do vencimento da dívida, e não no momento da constituição da garantia.

${ }^{546}$ Cf., especialmente, F. VIALE SALAZAR, El derecho de prenda y la realización de la prenda en lós códigos civiles de la República de Chile y de la República Argentina que recogen los proyectos Bello y Vélez Sársfield, respectivamente, in Revista Pontificia Universidad Católica del Perú, n 42, Lima, Pontificia Universidad Católica del Perú, 1987, p. 181; R. F. GARRIDO - L. O. Andorno, Código Civil Anotado - Derechos Reales, v. 4, Buenos Aires, Zavalía, 1976, p. 747; G. A. BORDA, Tratado de Derecho Civil - Reales, v. 2, Buenos Aires, Perrot, 1975, p. 383.

${ }^{547}$ Esse entendimento vai contra as notas que acompanham o código, nas quais se lê que, ainda que se provasse que a coisa não tem um valor superior à dívida que garante, não haveria 
$\mathrm{Na}$ Espanha $^{548}$, o pacto comissório não se encontra expressamente vedado aos contratos de penhor e hipoteca. No entanto, a regra deriva de uma interpretação extensiva do artigo 1.859, que estabelece taxativamente a proibição genérica de apropriação do bem por parte do credor $^{549}$.

Em outras palavras, pró́bem-se quaisquer acordos que tenham efeitos análogos àqueles do pacto comissório. A proibição a este, por sua vez, apenas é trazida de forma expressa no artigo 1.884 , em relação à anticrese.

Vale notar que, pela literalidade deste último dispositivo, caso não seja possível adjudicar o bem após duas hastas públicas, a propriedade poderá ser transferida ao credor, que será obrigado a confirmar a quitação. Trata-se de medida bastante semelhante àquela adotada pelo direito pátrio para a excussão do bem dado em alienação fiduciária ${ }^{550}$.

razão para autorizar o pacto comissório, sob o risco de que uma demasiada tolerância da lei levasse à multiplicação de convenções análogas que ocultassem abusos mais graves - cf. D. VELEZ SARSFIELD, Codigo de la Republica Argetina - tales como fueron publicadas, Buenos Aires, Pablo e Coni, 1872, p. 193.

${ }^{548}$ Sobre o tema, no direito espanhol - cf. M. I. Feliú REY, La prohibición del pacto comisorio y la opción em garantia, Madrid, Civitas, 1995, p. 35; R. GOLDSCHMIDT, Pacto comisorio, en Diccionario de Derecho privado, v. 2, Barcelona, Labor, 1961, p. 2866; J. ORLANDIS ROVIRA, La prenda como procedimiento coactivo, in Actas del Congreso Iberoamericano de Derecho Romano, t. 14, Madrid, Universidad de Murcia, 1942-1943, pp. 84 e ss.; B. GutiérRez FERNÁNDEZ, El derecho civil español - tratado de las obligaciones, t. 5, Madrid, Civitas, 1869, p. 256; J. M. ITURRASPE - M. A. PIEDEACASAS, Tratado de Derecho Civil - Derechos Reales, Santa Fé, Rubinzal-Culzoni, 2006, p. 432 e ss.; F. García GoyenA, Concordancias, motivos y comentários del Código civil español, t. 3-4, Madrid, Civitas, 1852, p. 176; M. Albaladejo, Derecho Civil-Derechos de Bienes, v. 2, Madri, Bosch, 1994, pp. 137 e ss.; J. M. MANReSA y NAVARro, Comentarios al Código civil español, t. 12, Madrid, Reus, 1969, p. 543; F. REGLERO CAMPOS, Ejecución de las garantías en la contratación mercantil, v. 2, Madrid, Consejo General de los Colegios Oficiales de Corredores de Comercio-Civitas, 1996, p. 421.

549 J. M. MANRESA Y NAVARRO, Comentarios cit. (nt. 548 supra), p. 543.

${ }^{550}$ Cf., nesse sentido, L. G. HADDAD, ao se referir à matéria de que tratam o Decreto-lei n. ${ }^{\circ}$ 911/69, a Lei n. ${ }^{\circ} 9.514 / 97$ e a Lei n. ${ }^{\circ} 10.931 / 04$ - cf. A proibição cit. (nt. 519 supra),p. 39.

Regra idêntica também se verifica no código civil chileno que, ao estabelecer a nulidade do pacto comissório em relação aos credores pignoratício e hipotecário, em seu art. 2.397, prevê que, na falta de oferta de aquisição por terceiros, é admitida a adjudicação do bem ao credor, desde que o valor do bem seja determinado por peritos e que a imputação ao montante do crédito se dê apenas até o valor assim determinado, sem prejuízo de outras formas de cobrança do crédito. Qualquer outro modo de disposição ou apropriação do bem empenhado, distinto dos expressamente previstos, é tido por ilícito.

Igualmente, pelo art. 2.882 do código civil mexicano, mostrando-se infrutífera a venda, o credor pode obter a adjudicação do bem, nos termos da lei processual. 
A atual orientação espanhola curiosamente diverge daquela estabelecida em seu anteprojeto de Código, que, no artigo $6^{\circ}$, autorizava o pacto comissório, desde que estabelecido de comum acordo entre as partes ${ }^{551}$.

A norma foi considerada "chocante" pela doutrina ${ }^{552}$, que a atribuiu exclusivamente ao gênio inventivo do legislador de então, já que entre suas possíveis fontes de inspiração, como o artigo 2.078 do Código francês, o artigo 2.150 do anteprojeto belga e o artigo 29 do Código prussiano, o pacto encontravase absolutamente proibido.

Também as Siete Partidas $^{553}$, aliás, proíbem o pacto. Excepcionalmente, contudo, autorizam a transferência da propriedade da coisa objeto do contrato de penhor ao credor, caso seja ela avaliada por "homes bonos" no momento em que verificado o inadimplemento. Sem qualquer ressalva, por outro lado, a proibição também é trazida no Fuero Real ${ }^{554}$.

A partir de 11 de março de 2005, estabeleceu-se por meio do Real Decreto-ley 5 uma importante exceção à proibição, reflexo de uma corrente "aperturista" 555 de pensamento. Grosso modo, o mencionado diploma legal visa estabelecer reformas urgentes para impulsionar a produtividade através das chamadas "garantias financeiras" firmadas entre entidades típicas do mercado financeiro ou entre tais entidades e demais pessoas jurídicas.

Por meio dele, passou-se a admitir, em caso de inadimplemento, a venda ou apropriação direta ao credor nos casos em que o objeto das garantias são bens efetivos - assim entendidos, e.g., dinheiro abonado em conta, valores negociáveis e outros instrumentos financeiros ${ }^{556}$.

551 "No puede el acreedor apropriarse la cosa recibida en prenda, ni disponer de ella, salvo pacto en contrario".

${ }^{552}$ Cf. F. GARCÍA GOYENA, Concordancias cit. (nt. 548 supra), p. 176.

${ }^{553}$ Cf. P. $5,13,12$.

${ }^{554}$ Cf. 3, 19, 9.

555 Cf. M. I. Feliú Rey, La prohibición cit. (nt. 548 supra), p. 42; F. REGLERO CAMPOS, Ejecución de las garantías cit. (nt. 548 supra), p. 427.

${ }^{556}$ Outra interessante reflexão sobre a mitigação do pacto surgida na Espanha foi suscitada pela Resolução da Direção geral dos Registros e Notariado, de 10 de junho de 1986. Essa resolução decorreu de controvérsia instaurada sobre a possibilidade de serem lavradas e registradas escrituras públicas que refletissem opções de compra sobre bens, outorgadas em garantia do pagamento de dívidas. A despeito de a jurisprudência dominante no Supremo Tribunal espanhol admitir como lícita a celebração de negócios fiduciários, a direção dos registros notariais 
Também o Bürgerliches Gesetzbuch conhece expressamente a proibição do pacto comissório, em relação à hipoteca (\$1.149) e ao penhor (§ 1.229). Uma das interessantes peculiaridades do direito alemão, nessa matéria, está em admitir a validade da dação em pagamento celebrada após o vencimento da obrigação, a exemplo da orientação posteriormente firmada pelos parágrafos únicos dos artigos 1.365 e 1.428 do CC/02.

Pelo sistema do BGB, aliás, em momento anterior à exigibilidade do débito, considera-se inadmissível o reconhecimento a validade do pacto comissório, ainda que acompanhado do pacto marciano. Isso porque semelhante situação violaria a imprescindível proporção entre o débito e o valor do bem excutido disciplinada em seus $\S 138$ e $139^{557}$.

De qualquer modo, curiosamente, se comparado ao restante dos países de direito ocidental europeu, o ordenamento alemão, em detrimento do pacto comissório, privilegia o uso de outros instrumentos negociais para realizar a função de garantia, como, e.g., a simples transferência da propriedade com escopo de garantia e esquemas contratuais análogos à reserva de propriedade ${ }^{558}$.

Dentre esses instrumentos, merece destaque a Sicherungsübereignung ${ }^{559}$, transferência da propriedade que se substancia em uma alienação de tipo fiduciário acompanhada do constituto possessório do bem dado em garantia. $\mathrm{O}$ negócio, mais comum às garantias mobiliárias ${ }^{560}$, consente ao

espanhóis entendeu que tal opção de compra em garantia violava a proibição do pacto comissório, prevista nos artigos 1.859 e 1.884, do Código Civil - cf., sobre o tema, L. G. HADDAD, A proibição cit. (nt. 519 supra), p. 39.

${ }_{557}$ Cf. nesse sentido, L. ENNERCCERUS - T. KIPP - M. WOLF - L. RAISER, Lehrbuch des Bürgerlichen Rechts III - Sachenrecht, Marburg, N. G. Elwert, 1904, pp. 57-58; L. RAAPE, Verfallklausel bei Pfand und Sicherung-Übereignung, Berlin, F. Vahlen, 1913, p. 102.

${ }^{558}$ Para a análise comparada entre o sistema alemão e o italiano, especificamente $-\mathrm{cf}$. M. BUSSANI, Il problema del patto commissorio - Studio di diritto comparato I, Torino, Giappichelli, 1999, p. 98.

559 Sobre o tema - cf., especialmente, R. SERICK, Eigentumsvorbehalt und Sicherungsübertragung VI, Heidelberg, Recht und Wirtschaft, 1963, pp. 132 e ss.; R. SERICK,, Deutsche Mobiliarsicherheiten, Heidelberg, Recht und Wirtschaft, 1988, pp. 488 e ss.; R. SERICK, Freigabeklausen, Deckungsgrenze und Haftungsbegrenze, in Neue juristische Wochenschrift, München, Beck, 1997, pp. 1592 e ss.; E. M. KIENINGER, Mobiliarsicherheiten im Europäischen Binnenmarkt, Baden-Baden, Nomos, 1996, pp. 67 e ss.

560 Teoricamente, nada impede sua aplicação em relação aos bens imóveis; na prática, contudo, prefere-se recorrer à constituição de simples direitos reais de garantia - cf. R. SERICK, 
credor adquirir a propriedade em garantia, que tem, porém, um conteúdo da propriedade plena enquanto durarem os efeitos da obrigação.

Em caso de inadimplemento, por força do o $\$ 138$ do BGB, recorre-se ao ius vendendi do credor, que será satisfeito até o limite de seu crédito. É possível, ainda, que, mediante prévio acordo entre as partes, possa o credor apropriar-se do bem, com a restituição ao devedor do valor excedente, sem que haja violação à proibição do pacto comissório, diante da inexistência de qualquer prejuízo ao vendedor ${ }^{561}$. Essa cláusula, no entanto, tem modesta aplicação, considerando-se que o predominante interesse dos financiadores não reside no bem em si, mas em seu correspondente econômico ${ }^{562}$.

A hipótese trazida pela Sicherungsübereignung conduz, assim, a um dos exemplos mais significativos de como um sistema jurídico culturalmente vizinho tenha sido capaz de romper com a tradicional - e ineficiente - separação entre os campos das obrigações e da responsabilidade patrimonial, em normas que privilegiam uma resolução mais elástica e moderna dos conflitos entre credor e devedor.

Ainda que o foco do presente item sejam os assim chamados países de tradição romano-germânica, restam algumas finais e pertinentes observações sobre o regime adotado no sistema norte-americano ${ }^{563}$.

Prevalece ao longo do território a regra trazida pelo artigo 9 do Uniform Commercial Code (“U.C.C.") ${ }^{564}$, que, desde 1.952, tem sido

Deutsche Mobiliarsicherheiten cit. (nt. 559 supra), p. 488. No mesmo sentido - cf. M. BUSSANI, Il problema cit. (nt. 558 supra), p. 98.

${ }^{561}$ Cf. R. SERICK, Eigentumsvorbehalt und Sicherungsübertragung i-VI, Heidelber, 19631986.

${ }^{562}$ Cf., nesse sentido, R. SERICK, Eigentumsvorbehalt cit. (nt. 559 supra), p. 132; E. M. KIENINGER, Mobiliarsicherheiten cit. (nt. 559 supra), p. 67.

563 A questão é mais amplamente abordada no Brasil - cf. L. G. HADDAD, A proibição cit. (nt. 519 supra), pp. 48 e ss.

Dispensa-se aqui a análise dos sistemas de Common Law. Isso porque ainda que preveja meios que impliquem na transferência física da coisa ao credor (como o instituto da pledge, por exemplo), a peculiar possibilidade de divisão do direito de propriedade constitui barreira que dificulta uma análise linear com sistemas romano-germânicos, que não a admitem. Sobre a impossibilidade de que uma eventual uniformização de regras sobre o tema atinja o direito inglês cf. G. McCORMACK, Secured Credit under English and American Law, Cambridge, Cambridge University Press, 2004, pp. 99-122. 
constantemente atualizado com o objetivo de harmonizar regras relativas a relações comerciais nos Estados Unidos.

A disciplina aplicável ao inadimplemento de dívidas amparadas por garantias consta da parte 6 do Article 9, sob o título Default (=Inadimplemento), que conta com 28 sections, também estas divididas em sub-itens ${ }^{565}$. A possibilidade de compra do bem dado em garantia pelo próprio credor garantido que guarda relação com o pacto comissório ${ }^{566}$ - está prevista na $§ 9-610(c)^{567}$.

Por esse dispositivo, a aquisição do bem dado em garantia pelo próprio credor apenas é possível por meio de hasta pública, observada a efetiva publicidade a terceiros sobre a ocorrência da venda, ou privadamente, quando os preços previamente fixados em mercado não estiverem sujeitos a negociações individuais.

Até este ponto, não parece haver relevante diferença com os ordenamentos analisados. No entanto, há, no regime adotado pelo U.C.C., uma importante peculiaridade que merece ser destacada: a disciplina norte-americana

$564 \mathrm{O}$ texto do dispositivo é bastante extenso e complexo. Não à toa, inumeráveis são os trabalhos que se debruçam sobre o tema e as mudanças legislativas que vem sofrendo com o passar do tempo. Sobre o diploma legislativo e as peculiaridades da aplicação de seu texto - cf. G. MCCORMACK, Secured Credit cit. (nt. 563 supra), pp. 70 e ss.; C. COOPER - S. O. WeISE - E. E. SMITH, The New Article 9 - Uniform Commercial Code, 2 ${ }^{\mathrm{a}}$ ed., Chicago, American Bar Association, 2000, pp. 21 e ss; T. R. ZINNECKER, The Default Provisions of Revised Article 9, Chicago, American Bar Association, 2002, pp. 16 e ss.; L. A. Hellerstein - S. A. Hellerstein, Secured transactions under article 9 - Uniform Commercial Code of Colorado, Denver, A. B. Hirschfield Press, 1967, pp. 144 e ss.; R. Goode, Legal Problems of Credit and Security, $5^{\text {a }}$ ed., London, Sweet \& Maxwell, pp. 15 e ss.; G. GILMORE, Security Interests in Personal Property, v. 1, $5^{\text {a }}$ ed., New Jersey, The Lawbook Exchange, 2007, pp. 288 e ss; E. WARREN - J. L. WESTBROOK, The law of debtors and creditor - Text, cases and problems, $6^{\mathrm{a}}$ ed., Austin, Wolters Kluwer, 2009, pp. 71 e ss.; E. WARREN, Bankruptcy and Article 9 - Statutory supplement, Austin, Wolters Kluwer, 2010, pp. 10 e ss.

${ }^{565}$ Ao todo, apenas o article 9 conta com 801 sections, distribuídas em 8 diferentes partes. Para o inteiro teor do texto com comentários oficiais - cf. E. WARREN, Bankruptcy cit. (nt. 564 supra), pp. 10 e ss.

${ }^{566}$ Contra a existência de proibição do pacto comissório no direito norte-americano, M. B. PENTEADO entende que o Article 9 do UCC apenas admitiria a dação em pagamento do bem, após o vencimento - cf. O penhor de ações no direito brasileiro, São Paulo, Malheiros, 2008, p. 202.

567 "A secured party may purchase collateral: (1) at a public disposition; or (2) at a private disposition only if the collateral is of a kind that is customarily sold on a recognized market or the subject of widely distributed standard price quotations" (= o credor pode adquirir para si o bem dado em garantia: (1) em uma hasta pública; ou (2) em uma disposição privada, apenas se o bem for costumeiramente vendido em um mercado reconhecido ou objeto de cotações de preço amplamente padronizadas e divulgadas) (tradução livre). 
presume que o momento de maior fragilidade do devedor seria o da constituição da dívida ou da garantia, e não após seu vencimento, como sói entender.

Assim, ao invés de estabelecer meios para contornar as consequências do inadimplemento, como, e.g, a possibilidade de venda mediante avaliação de terceiros ou a dação em pagamento, o desenvolver das relações comerciais foi regulado através de normas cogentes ${ }^{568}$ dirigidas à máxima "the context of default offers great opportunity for overreaching" ${ }^{569}$, prevista na seção 602 do diploma.

É importante lembrar que também a dação em pagamento é aceita pelo sistema ${ }^{570}$, para pagamento parcial ou total do débito, com a ressalva de que o consentimento do devedor seja manifestado após o vencimento da dívida ${ }^{571}$.

Também a ocorrência de déficit ou excesso no produto da venda, em relação ao valor da dívida, deve ser feita considerando-se o preço que um terceiro independente pagaria pelo bem dado em garantia, e não o preço efetivamente aceito pelo credor ou por parte a ele relacionada ${ }^{572}$.

${ }^{568}$ Cf., nesse sentido, L. G. HADDAD, A proibição cit. (nt. 519 supra), pp. 49-50. O autor lembra que, ao longo do Article 9, são qualificadas como cogentes as regras sobre uso e operação do bem dado em garantia pelo credor garantido (Section 9-207(b)(4)(C)), requisições de extratos e demonstrativos da dívida garantida ou dos bens dados em garantia (Section 9-210), apossamento e excussão da garantia (inclusive no que se refere à obrigação de retomar a posse do bem "without breach of the peace" (Sections 9-607(c) e 9-609), imputação e pagamento de cobranças in natura (via excussão ou alienação) (Sections 9-608(a) e 9-615(c)), cálculo, apuração, prestação de contas e devolução de excessos apurados na excussão da garantia (Sections 9-608(a), 9-615(d) e 9-616), alienação do bem dado em garantia (Sections 9-610(b), 9-611, 9-613 e 9-614), cálculo de déficit ou excesso nos recursos obtidos com alienação do bem dado em garantia ao próprio credor garantido ou a pessoa a ele relacionada (Section 9-615(f)), aceitação do bem dado em garantia como pagamento da dívida (Sections 9-620, 9-621 e 9-622), remição de garantia (Section 9-623), renúncias admitidas (Section 9-624) e responsabilidade do credor garantido por eventual descumprimento das referidas normas cogentes (Section 9-625 e 9-626).

No mesmo sentido - cf. G. MCCORMACK, Secured Credit cit. (nt. 563 supra), p. 73.; C. COOPER - S. O. WEISE - E. E. SMITH, The New Article 9 cit. (nt. 564 supra), pp. 29-31.

569 (= a situação de inadimplemento oferece grande oportunidade para o excesso) (tradução livre)

\footnotetext{
${ }^{570}$ De modo geral, §9-620, U.C.C..

${ }^{571} \S 9-620(\mathrm{c})(1-2)$, U.C.C.

${ }^{572}$ Cf. § 9-615(f), U.C.C..
} 


\subsection{CODIFICAÇÕES EM QUE A PROIBIÇÃO FOI REVOGADA}

Quanto à proibição do pacto comissório, pode-se dividir o posicionamento do ordenamento francês em dois grandes períodos: antes e depois da Ordonnance de 23 de março de $2006^{573}$, que deu nova redação ao artigo 2.348 do Code Civil ${ }^{574}$.

Como seria natural supor, o mais popularmente chamado Code Napoléon, que tanto inspirou o movimento codificador dos séculos XIX e XX, foi um dos principais responsáveis pela difusão da proibição no mundo ocidental, ao elencá-la em seus artigos 2.078 e $2.088^{575}$, relativamente ao penhor e à anticrese, inclusive nas hipóteses de pacto ex intervallo ${ }^{576}$.

${ }^{573}$ Data de publicação no Journal Officiel francês, a partir de quando passa a ter vigor - cf. Philippe Simler, La réforme du droit des sûretés - Un livre IV nouveau du code civil, Paris, Dalloz, 2006, p. 125.

574 “Art. 2.348 - Il peut être convenu, lors de la constitution du gage ou postérieurement, qu'à défaut d'exécution de l'obligation garantie le créancier deviendra propriétaire du bien gagé. La valeur du bien est déterminée au jour du transfert par un expert désigné à l'amiable ou judiciairement, à défaut de cotation officielle du bien sur un marché organisé au sens du code monétaire et financier. Toute clause contraire est réputée non écrite. Lorsque cette valeur excède le montant de la dette garantie, la somme égale à la différence est versée au débiteur ou, s'il existe d'autres créanciers gagistes, est consignée".

Dentre os artigos publicados após a ordonnance - cf. S. HEBERT, Le pacte commissoire après l'ordonnance du 23 mars 2006, in Recueil Dalloz 29 (2006), pp. 2052-2058; D. CHEMINBOMBEN, Ordonnance "sûretés" - fiche de lecture du nouveau libre IV du Code Civil, in Revue Lamy Droit des Affaires 5 (2006), pp. 29-32; V. AVENA-ROBARDET, La réforme du droit des sûretés, in Recueil Dalloz 19 (2006), pp. 1289-1320; A. LIARD, Les principaux apports de la réforme des sûretés, in Option Finance. 880 (2007), p. 28; S. PIEDELIEVRE, Premier aperçu sur la réforme du droit des sûretes par l'ordonnance du 23 mars 2006, in Répertoire du Notariat Defrénois 10 (2006), pp. 791-813; E. FREMEAUX - G. DAUBLON, La réforme du droit des sûretés in Répertoire du Notariat Defrénois 10 (2006), pp. 1085-1101; J. F. ADELLE, La réforme des sûretés mobilières corporelles et les opèrations de financemente - ambitions et limites, in Option Finance 893-894 (2007), pp.36-37.

575 “Art. 2.078 - Le créancier ne peut, à défaut de payement, disposer du gage; sauf à lui à faire ordonner en justice que ce gage lui demeurera en payement et jusqu 'à due concurrence, $d$ ' après une estimation faite par experts, ou qu'il será vendu aux echères".

"2.088 - Le créancier ne devient point propriétaire de l'immeuble par le seu défaut de payement au terme convenu; toute clause contraire est nulle: en ces cas, Il peut poursuivre l'expropiation de son débiteur par lês voies légales".

Sobre a ausência à menção do pacto marciano nesses artigos - cf. L. AYNÈS - P. CROCQ, Les sûretés - La publicite foncière, $5^{\mathrm{a}}$ ed., Paris, Cujas, 1993, p. 239.

576 Cf. V. MARCADÉ, Explication théorique et pratique du Code Napoléon, t. 2, Paris, Delamonte, 1867, p. 697. Antes do Code, porém, o repúdio ao pacto comissório já se fazia presente nas práticas negociais - cf. C. E. DELVINCOURT, Institutes de droit civil français, t. 2, $2^{\mathrm{a}}$ ed., Paris, P. Gueffier, 1810, p. 234. 
Por esses dispositivos, apenas permitia-se que, verificado o inadimplemento, fosse o preço obtido em hasta pública após a avaliação da coisa por peritos, sendo o credor ressarcido até o limite de seu crédito. Além disso, estabelecia-se a nulidade como sanção para qualquer acordo que previsse o pacto.

O silêncio em relação à hipoteca deveu-se à inderrogabilidade do procedimento executório como regra ao instituto. Em outras palavras, celebrada a hipoteca, não era às partes facultado convencionar um procedimento de execução diverso daquele legal - o que, por si só, já inviabilizaria a eventual celebração do pacto comissório $^{577}$.

Posteriormente, a Ordonnance de 23 de março de 2006 teve seus efeitos modulados ex nunc, entendendo lícitos, portanto, os contratos celebrados em momento posterior à sua publicação. Aos demais, contudo, também trouxe uma importante mudança: com ela, a sanção aplicável passou a ser a da anulabilidade - e não mais da nulidade - admitindo-se, ainda, a renúncia do devedor à correspondente pretensão.

Grosso modo, a medida autorizou o pacto comissório genericamente em matéria de garantias ${ }^{578}$ e especificamente em relação ao penhor ${ }^{579}$, à anticrese $^{580}$, e à hipoteca ${ }^{581}$. A conclusão de um pacto comissório continuou sendo vedada à garantia sobre stocks $^{582}$, à garantia relativa aos créditos de consumo ${ }^{583} \mathrm{e}$ ao penhor de fundos de comércio ${ }^{584}$.

Importante ressaltar que essa nova configuração da legislação francesa foi fruto de um esforço coletivo através da chamada Commission Grimaldi,

${ }^{577}$ Cf. L. AYNÈS - P. CROCQ, Les sûretés cit. (nt. 575 supra), p. 238.

${ }^{578}$ Cf. artigos 1.353 e 2.346 a 2.348 do Código Civil francês e artigo 521-3 do Código Comercial francês.

${ }^{579}$ Cf. artigo 2.365 do Código Civil francês.

${ }^{580} \mathrm{Cf}$. artigo 2.388 do Código Civil francês.

${ }^{581}$ Cf. artigos 2458 e 2.459 do Código Civil francês e artigo 311-32 do Código de Defesa do Consumidor francês.

${ }^{582}$ Cf. artigo 527-10 do Código Comercial francês.

${ }^{583}$ Cf. artigo 311-32 do Código de Defesa do Consumidor francês.

${ }^{584}$ Trata-se de entendimento doutrinário - cf. A. LIARD, Les principaux apports cit. (nt. 574 supra), p. 28. 
formada predominantemente por acadêmicos, advogados e políticos ${ }^{585}$, que objetivou uma mais ampla modernização do sistema de garantias francês.

Em seu relatório ${ }^{586}$, contrariando entendimento já tão sedimentado, entendeu o grupo pela ausência de incompatibilidade entre o pacto comissório e a proteção do devedor e dos demais credores ${ }^{587}$. Entendeu-se que, com a medida, é colocado à disposição do credor um meio mais "simple, rapide et peu onéreux" 588 de realização da garantia. Algumas providências, de qualquer modo, foram tomadas para que esses últimos não ficassem desamparados.

É o que ocorre, e.g., quando não houver cotação do bem em bolsa ou mercado de balcão organizado nos termos do Code Monétaire et Financier. Nesses casos, a transferência de propriedade, por força do pacto comissório, ainda que ex intervallo, dependerá da determinação do valor do bem, no momento da própria transferência, por um perito, que poderá ser designado judicialmente ou pelo mero consenso das partes. Qualquer cláusula contratual que vise a eliminar ou obviar essa exigência de avaliação é reputada não escrita ${ }^{589}$.

${ }^{585}$ A elaboração do correspondente projeto de lei foi confiada a uma comissão presidida pelo Prof. Michel Grimaldi, da Université Pantheon-Assas (Paris II), e também presidente da Association Henri Capitant des Amis de la Culture Juridique Française. Integraram o grupo, nomeado em 2003 pelo Ministério da Justiça da França, o Prof. Laurent Aynés (PantheonSorbonne, Paris I), Annie Bac (Fédération Bancaire Française), Prof. Pierre Crocq (PantheonAssas, Paris II), Dominique Dos-Reis (conseiller à la Cour dAppel de Paris), Éliane Frémeauc (notaire à Paris), Alain Gourio (Banque BNP-Paribas), Alain Provansal (avocat au Barreau de Marseille), Philippe Simler (Université Robert Schuman de Strasbourg) e Prof. Hervé Synvet (Pantheon-Assas, Paris II)- Republique Française, Rapport à Monsieur Dominique Perben, Garde des Sceaux, Ministre de la Justice, issue par le Groupe de travail relatif à la reforme Du droit des sûretés.

586 Também publicado no Journal Officiel em 26/03/2006. Disponível em: http://www.legifrance.gouv.fr/affichTexte.do? cidTexte $=$ JORFTEXT000000456743\&dateTexte $=\& c$ ategorieLien=id (consulta em 27/12/2013).

${ }^{587} \mathrm{O}$ assunto será retomado - cf. item III.3.

${ }^{588} \mathrm{Cf}$. item 1.2.2.2.1.2 do relatório cit. (nt. 586 supra).

${ }^{589}$ Cf. artigos 2.347 e 2.348 do Código Civil francês, com a redação dada pela ordonnance n. ${ }^{\circ} 2006.348$, de 23 de março de 2006. 


\title{
2. A PROIBIÇÃO DO PACTO COMISSÓRIO NO CC/02
}

\author{
Em sua Consolidação das Leis Civis, A. TeIXEIRA DE FreITAS ${ }^{590}$
} expressamente reconheceu o direito do credor de, verificado o inadimplemento, promover a alienação do bem, desde que justo seu preço. Por "justo preço" devese entender aquele determinado por dois avaliadores juramentados e escolhidos de comum acordo pelas partes ${ }^{591}$. Sua fixação, portanto, não poderia ser meramente arbitrária.

Tal ressalva não foi reproduzida pelo $\mathrm{CC} / 16^{592}$, que, ao estabelecer a proibição do pacto comissório em seu art. 765 , declarava nula a cláusula que autorizasse, nos contratos de penhor, hipoteca e anticrese, a transferência ao credor da propriedade do bem objeto da garantia, em caso de inadimplemento.

Também a legislação extravagante previa a proibição em dois principais diplomas legislativos:

${ }^{590}$ Cf. A. TeIXeIRA DE Freitas, Consolidação das leis civis, v. 1, Brasília, Senado Federal, 2003. pp. 475-476.

Sobre A. TEIXEIRA DE FREITAS, sua obra e influência sobre a legislação brasileira - cf. I. M. POVEDA VELASCO, Três vultos da cultura jurídica brasileira - Augusto Teixeira de Freitas, Tobias Barreto de Menezes e Clóvis Beviláqua, in História do direito brasileiro (leituras da ordem jurídica nacional), São Paulo, Atlas, 2003, pp. 35 e ss.; Sílvio A. B. MEIRA, Teixeira de Freitas (o jurisconsulto do império), Rio de Janeiro, Olympio, 1979, pp. 3 e ss; Sílvio A. B. MEIRA, O pensamento criador de Teixeira de Freitas, in Novos e velhos temas de direito, Rio de Janeiro, Forense, 1973, pp. 247 e ss.; S. SCHIPANI, Il "méthodo didáctico" di Augusto Teixeira de Freitas (prime osservazioni), in La codificazione del diritto romano comune, Torino, Giappichelli, 1999 , pp. 319 e ss.

${ }^{591}$ Em nota acrescida na terceira edição da obra A. TEIXEIRA DE FREITAS vai além e sugere que "se o declarado preço não for justo, a ponto de haver lesão enorme, cabe o remédio da Ord. L.4 $4^{\circ}$ T.13" - cf. Consolidação cit. (nt. 590 supra), p. 475.

592 Como nota L. G. HADDAD, na legislação brasileira, o termo aparece com sentido próximo ao aqui descrito no art. $107, \S 4^{\circ}$, da Lei n. ${ }^{\circ} 6.404$, de 15 de dezembro de 1976 . Ao estabelecer os poderes que assistem à companhia em caso de mora do acionista no cumprimento da obrigação de integralizar as ações subscritas, esse dispositivo atribui à companhia a faculdade de "fazer suas as entradas realizadas, integralizando-as com lucros ou reservas, exceto a legal". $\mathrm{Na}$ ausência desses lucros ou reservas, a norma confere o prazo de um ano para a companhia alienar "as ações caídas em comisso" - cf. A proibição cit. (nt. 519 supra), p. 27.

M. CARVAlHosA, em comentário a esse artigo, equipara essa previsão legal a um autêntico pacto comissório - cf. Comentários à lei de sociedades anônimas, v. 2, $4^{\mathrm{a}}$ ed., São Paulo, Saraiva, 2008, pp.289-292. 
a) A Lei n. ${ }^{\circ}$ 4.728/65, também conhecida como Lei do Mercado de Capitais, em seu art. $66, \S 7^{0593}$, estendeu a proibição à recém-concebida alienação fiduciária de bens móveis em garantia ${ }^{594}$.

b) A Lei n. ${ }^{\circ} 4.864 / 65$, que cuida de medidas de incentivo à construção civil, prevê, em seu art. $23, \S 3^{\circ}$, a nulidade da cláusula que autorize o cessionário fiduciário dos direitos decorrentes dos contratos de alienação das unidades habitacionais a ficar com os direitos cedidos em garantia, no caso de inadimplemento.

Ainda na vigência do $\mathrm{CC} / 16$, vale mencionar os interessantes questionamentos doutrinários sobre a proibição presentes nos trabalhos de J. M. CARVAlHo SANTOS e, especialmente, de A. FraGA ${ }^{595}$.

A J. M. CARVALHO SANTOS ${ }^{596}$ causou especial perplexidade a teórica possibilidade de se tratar com menor rigidez o pacto comissório ex intervallo do que o in continenti. Isso porque, para o autor, a constituição da garantia, por si só, não seria suficiente para mitigar a pressão exercida sobre o devedor, se comparada àquela que lhe afligiria no momento da assunção da dívida.

${ }^{593}$ Poucos anos depois, em 1969, o Decreto-lei n. ${ }^{\text {}} 911$ reformou a redação do aludido art. 66 da Lei n. ${ }^{\circ} 4.728 / 65$, com o propósito de incrementar os poderes que assistiam aos credores titulares de alienação fiduciária em garantia. Não obstante tais mudanças, protetivas dos interesses dos credores, a vedação do pacto comissório continuou a constar da lei modificada, no $\S 6^{\circ}$ do mesmo art. 66, com a redação que lhe foi atribuída pelo mencionado Decreto-lei n. ${ }^{\circ}$ 911/69.

${ }^{594}$ Sobre a alienação fiduciária em garantia - cf. O. GOMES, Direitos reais, $19^{\mathrm{a}}$ ed., Rio de Janeiro, Forense, 2008, pp. 386-390; J.C. MOREIRA ALVES, Da alienação fiduciária em garantia, $2^{a}$ ed., São Paulo, Saraiva, 1979, pp. 17 e ss.; F. S. AMARAL NETO, A alienação fiduciária em garantia no direito brasileiro, in Contratos em espécie: atribuição patrimonial e garantia, G. TEPEDINO - L. E. FACHIN (org.), São Paulo, RT, 2011, pp. 315-333; M. N. ChAlHuB, Negócio fiduciário, alienação fiduciária, cessão fiduciária e securitização, $3^{\mathrm{a}}$ ed., Rio de Janeiro, Renovar, 2006, pp. 321 e ss.; P. Restiffe Neto e P. S. RestifFe, Garantia fiduciária, $3^{a}$ ed., São Paulo, RT, 2000, pp. 54 e ss.

${ }^{595}$ A contraposição entre os dois autores foi primeiramente trazida por L. G. HADDAD - cf. A proibição cit. (nt. 519 supra), pp. 58-60.

${ }^{596}$ Código civil brasileiro interpretado - Direito das coisas (arts. 755-862), v. 10, $9^{\mathrm{a}}$ ed., Rio de Janeiro, Freitas Bastos, 1964. p. 91.

J. M. CARVAlHo SANTOS é ainda, dentre os autores brasileiros consultados, quem mais se dedica a explicar os argumentos favoráveis e contrários à licitude do pacto marciano, sendo ainda dos primeiros a defender a validade, após o vencimento, da dação em pagamento do bem empenhado - cf. Código civil cit. (nt. 596 supra), p. 92-95. No mesmo sentido - cf. T. FULGENCIO, Direito real de hipoteca, v. 1, $2^{\mathrm{a}}$ ed., Rio de Janeiro, Forense, 1960, pp. 110-111; CAIO MÁRIO, Instituições de direito civil, v. 4, $15^{\mathrm{a}}$ ed., Rio de Janeiro, Forense, 2001, pp. 209-210. Essa permissão foi depois positivada nos parágrafos únicos dos artigos 1.365 e 1.428 do Código Civil. 
Contrariamente, seria na primeira situação, na qual já está sujeito às medidas coercitivas atribuídas ao credor, mais do que na segunda, que o devedor estaria mais exposto ao risco de se ver compelido a concordar com uma dação em pagamento que lhe diminua o patrimônio de modo desproporcional ao valor do débito inadimplido ${ }^{597}$.

No mesmo sentido, A. FrAGA ${ }^{598}$, cuja contribuição ao estudo do tema é deveras mais substancial, posiciona-se contra a mitigação da rigidez das regras relativas à proibição nos pactos celebrados ex intervallo.

Seus argumentos são bastante semelhantes aos de J. M. CARVALHO SANTOS, por também entender falaciosa a possibilidade de que, após a constituição da garantia, restasse menor a necessidade de proteção do devedor. Afinal, contrariamente, a proximidade do vencimento levaria ao incremento de medidas coercitivas por parte do credor, interessado no adimplemento, tornando ainda mais evidente a posição de inferioridade daquele.

Ainda, após identificar no pacto comissório um problema de função ou, em outros termos, de incompatibilidade com a causa -, e considerá-lo espécie de venda forçada e condicional ${ }^{599}$, o autor elenca um rol de variações de natureza potestativa com que o pacto comissório pode ser configurado.

São elas ${ }^{600}$ : (a) A autorização para que, por qualquer preço, o bem dado em garantia seja alienado pelo credor; (b) A autorização para que o credor, por preço previamente ajustado, venha a se tornar titular do bem dado em garantia; (c) A autorização para que, pelo preço estimado por ele próprio, torne-se o credor titular do bem dado em garantia.

Por fim, A. FRAGA ${ }^{601}$ postula ainda a validade da transferência da titularidade do bem empenhado, pelo devedor ao credor, mediante venda ou dação

${ }^{597}$ Cf. J. M. Carvalho SAnTos, Código civil cit. (nt. 596 supra), p. 94.

${ }^{598}$ Direitos reaes de garantia - Penhor, anticrese e hipoteca, São Paulo, Saraiva, 1933, pp. 119-125.

${ }^{599}$ Cf., no mesmo sentido, L. C. Penteado, Direito das coisas, São Paulo, RT, 2008, p. 437.

${ }^{600}$ Cf. A. Fraga, Direitos reaes cit. (nt. 598 supra), p. 121.

${ }^{601}$ Direitos reaes cit. (nt. 598 supra), p. 122. 
em pagamento, cuja licitude defende tanto antes quanto após o vencimento ${ }^{602}$. Esta, inclusive, foi a solução posteriormente consagrada nos parágrafos únicos dos artigos 1.365 e 1.428 do CC/02.

Da literalidade do texto destes últimos dispositivos, analisados conjuntamente, tem-se que:

a) A proibição do $\mathrm{CC} / 02$, a exemplo do $\mathrm{CC} / 16$, aplica-se às garantias reais tradicionais (art. 1.428), estendendo-se, ainda, à alienação fiduciária em garantia (art. 1.365).

b) A constituição do pacto comissório pressupõe: (i) a existência de uma relação jurídica obrigacional, de caráter principal, ainda não exigível; (ii) a existência de uma relação jurídica de caráter acessório, correspondente à propriedade fiduciária (art. 1.365), ao penhor, à anticrese ou à hipoteca (art. 1.428); e (iii) a estipulação expressa de cláusula que autorize o credor a "ficar com"603 o bem objeto da garantia, se a dívida não for paga no vencimento.

c) A sanção estabelecida pelo legislador de 2002 para seu descumprimento foi a nulidade.

d) Reputa-se lícita, no lugar do pacto comissório, a dação em pagamento, após o vencimento.

Assim, para a melhor compreensão dessas regras, ao longo deste item, dividir-se-á o estudo do instituto quanto ao seu alcance ("a", 2.1), conteúdo ("b", 2.2), sanção aplicável (“c”, 2.3) e sua relação com a dação em pagamento após o vencimento ("d", 2.4).

${ }^{602}$ A. FRAGA defende a validade do pacto marciano, segundo a tradição do direito lusobrasileiro, no sentido de aceitar que o credor se torne titular do bem dado em garantia, desde que o faça "pelo justo preço", assim definido por terceiros isentos - cf. Direitos reaes cit. (nt. 598 supra), p. 122.

Como lembra L. G. HADDAD, o referido autor, no entanto, nada explica sobre o que diferenciaria uma dação em pagamento condicional - pactuada antes do vencimento - do pacto comissório propriamente dito. Além disso, fica igualmente sem resposta a questão sobre em que medida essa dação em pagamento se diferenciaria da modalidade de pacto comissório identificada pelo próprio A. FRAGA, como a autorização para que o credor torne-se titular do bem dado em garantia, por preço previamente ajustado - cf. A proibição cit. (nt. 519 supra), p. 60.

${ }^{603}$ Sobre a crítica à expressão - cf. item IIII.2.2. 
Antes, porém, à luz do CC/02, pode-se conceituar o pacto comissório como a convenção acessória ${ }^{604}$ com efeitos translativos suspensivamente $\operatorname{condicionados}^{605}$ ao inadimplemento da obrigação principal, que importa para o credor insatisfeito o poder potestativo de conservar para si, na condição de proprietário, a coisa entregue em garantia.

\subsection{QUANTO AO ALCANCE}

Durante a vigência do CC/16, a jurisprudência do Supremo Tribunal Federal ("STF”) muito discutiu, e a do Superior Tribunal de Justiça (“STJ”) até hoje discute, se o pacto comissório seria proibido apenas em relação às garantias reais tradicionais ou, ainda, sempre que houvesse transferência da titularidade de posições jurídicas com fulcro a assegurar a liquidação do débito ${ }^{606}$.

A necessidade prática da discussão sobre o âmbito de incidência da vedação levou, não raras vezes, a questionamentos nas decisões das cortes superiores que passaram à margem da própria doutrina pátria, de modo geral, pouco dada à reflexão sobre o tema.

Segundo L. G. HADDAD ${ }^{607}$, o vetor orientador dos tribunais acima mencionados compreende-se temporalmente, no caso do STF, antes e depois de 1973, e, no caso do STJ, a partir de $1988^{608}$. Assim:

a) STF, até $1973^{609}$ : Privilegiou-se uma abordagem predominantemente funcional do instituto, estendendo a proibição também aos

${ }^{604}$ Cf. A. SASSI, que rebatendo a tese autonomistica, considera que o pacto comissório desvinculado de uma pré-existente obrigação nada mais seria do que uma datio in solutum - cf. Garanzia del credito cit. (nt. 4 supra), p. 197.

${ }^{605}$ Cf. G. CHINÈ - M. LASCIALFARI - F. MAGNI, Le garanzie rafforzate del credito, Torino, UTET, 2000, p. 179.

${ }^{606}$ Mesmo nos casos das garantias reais típicas, sua conexão com o pacto é totalmente eventual - cf. C. M. BIANCA, Realtà sociale ed effettività della norma, Milano, Giuffrè, 2002, p. 730. Sobre o debate da jurisprudência italiana quanto à aplicação do pacto comissório além das garantias reais típicas - cf. F. GiGLIOTTI, Il divieto cit. (nt. 4 supra), p. 38.

${ }^{607}$ A proibição cit. (nt. 519 supra), pp. 137-167.

608 O Superior Tribunal de Justiça ("STJ"), vale lembrar, foi criado pela CF/88 - cf., especialmente, artigos 104 e 105 da CF/88.

${ }^{609}$ Cf. STF, Segunda Turma, RE n. ${ }^{\circ}$ 60.699/SP, Rel. Min. Aliomar Baleeiro, 8/11/1966, in RTJ 42/331; STF, Terceira Turma, RE n. ${ }^{\circ}$ 63.128/SP, Rel. Min. Hermes Lima, 8/3/1968; STF, Primeira Turma, RE 70.497/RS, Rel. Min. Luiz Galotti, 3/9/1970. 
negócios fiduciários, cuja aplicação seria defesa sempre que visassem contornar a vedação ao pacto, qualificado como princípio de ordem pública ${ }^{610}$.

A regra proibitiva, nesse sentido, passou a ser aplicável a todos os negócios jurídicos em que houvesse transmissão de titularidade de bens e direitos em garantia, independentemente da estrutura utilizada para atingir tal objetivo (hipoteca, anticrese, penhor, alienação fiduciária ou propriedade plena) ${ }^{611}$.

b) STF, após 1973 e até $1988^{612}$ : Com o julgamento do emblemático RE 71.616/SP ${ }^{613}$, o aspecto estrutural ${ }^{614}$ passa a ser privilegiado em detrimento do funcional, até então adotado pela Corte. A partir de então, a vedação do pacto comissório entendeu-se cabível, exclusivamente, aos casos de hipoteca, penhor e anticrese, com o acréscimo trazido pelas Leis n. ${ }^{\circ} 4.728 / 65$ e n. ${ }^{\circ} 4.864 / 65$.

Por consequência, reputava-se lícita qualquer cláusula comissória que resultasse na transmissão de propriedade plena, operada por negócios fiduciários não simulados ou fraudulentos ${ }^{615}$. Afinal, tratando-se de propriedade plena, ainda que transmitida para fins de garantia, não se poderia esvaziar do credor a condição de proprietário por ele justamente titularizada ${ }^{616}$.

c) STJ, após $1988^{617}$ : A jurisprudência do STJ retomou a linha firmada pelo STF anteriormente a 1973, sem que, para tanto, demonstrasse grande

${ }^{610}$ Cf. STF, Segunda Turma, RE n. ${ }^{\circ}$ 60.699/SP, Rel. Min. Aliomar Baleeiro, 8/11/1966, in RTJ 42/331.

${ }^{611}$ Contra - cf. F. C. PONTES DE MIRANDA, Tratado cit. (nt. 10 supra), pp. 332-333.

${ }^{612}$ Cf. STF, Primeira Turma, RE n. ${ }^{\circ}$ 71.616/SP, Rel. Min. Rodrigues Alckmin, 11/12/1973; STF, Segunda Turma, RE n. ${ }^{\circ}$ 82.447/SP, Rel. Min. Cordeiro Guerra, 8/6/1976; STF, Primeira Turma, RE n. ${ }^{\circ}$ 85.156/PR, Rel. Min. Cunha Peixoto, 16/02/1979; STF, Primeira Turma, RE n. ${ }^{\circ}$ 86.981/PR, Rel. Min. Cunha Peixoto, 21/11/1978; STF, Primeira Turma, RE n. ${ }^{\circ}$ 90.648/SP, Rel. Min. Soares Muñoz, 8/5/1979; STF, Primeira Turma, RE 98.947/PR, Rel. Min. Alfredo Buzaid, 22/6/1984.

${ }^{613}$ STF, Primeira Turma, Rel. Min. Rodrigues Alckmin, 11/12/1973.

${ }^{614}$ Cf. F. C. Pontes De MirAndA, Tratado cit. (nt. 10 supra), p. 123, J. C. MoreirA Alves, Da alienação cit. (nt. 594 supra), pp. 133-135; O. GoMES, Alienação Tratado cit. (nt. 594 supra), p. 32 e ss.

${ }^{615}$ É o que aponta o mais recente entendimento do STF sobre a matéria - cf. STF, Primeira Turma, RE n. ${ }^{\circ}$ 98.947/PR, Rel. Min. Alfredo Buzaid, 22/6/1984.

${ }^{616}$ Cf., nesse sentido, F. C. PONTES DE MIRANDA, para quem há uma significativa diferença estrutural entre os direitos reais de garantia e os direitos reais em garantia, que são direitos reais plenos. Por isso, neste último caso, ainda que a propriedade seja transmitida para fins de garantia, o adquirente é dominus pleno, sendo inviável aplicar-lhe a proibição do pacto comissório - cf. Tratado cit. (nt. 10 supra), p. 123.

${ }^{617}$ A orientação dominante teve origem no aresto proferido nos autos do RESP n. ${ }^{\circ}$ 2.216/SP - cf. STJ, Terceira Turma, Rel. Min. Nilson Naves, 28/05/1991. Desde então, um número 
preocupação em bem fundamentar sua posição. De todo modo, predomina hodiernamente o entendimento jurisprudencial de que, no caso da proibição do pacto comissório, prevalece o aspecto funcional.

Nesse sentido, pode-se afirmar que a ratio inerente à vedação visa atingir um mais amplo resultado econômico ${ }^{618}$, ao sancionar qualquer negócio que predetermine um escopo translativo de um bem, do devedor ou de terceiro, como consequência do inadimplemento da obrigação ${ }^{619}$.

\subsection{QUANTO AO CONTEÚDO}

Reproduzindo a má técnica do $\mathrm{CC} / 16$, os dispositivos relativos à proibição do CC/02 vedam aos credores pignoratícios, hipotecários, anticréticos e fiduciários "ficar com" o bem objeto da garantia, em caso de inadimplemento. Resta, então, saber qual o sentido que a vulgar expressão visa atingir.

Preliminarmente, tem-se que o direito de sequela, inerente às complexas posições jurídicas de direito das coisas, afasta, por si só, a possibilidade de que a expressão signifique a mera transferência da posse, mediata ou não ${ }^{620}$, ao credor. Isso porque, como bem se sabe, os credores das relações abarcadas pela regra já têm, em caso de inadimplemento do devedor, direito à posse do bem ${ }^{621}$.

representativo de acórdãos do STJ tratou, ou ao menos tangenciou o assunto, conforme o caso, sempre em oposição à linha estabelecida pelo STF a partir de 1973 - cf. STJ, Terceira Turma, RESP n. ${ }^{\circ}$ 21.681/SP, Rel. Min. Eduardo Ribeiro, 29/06/1992; STJ, Terceira Turma, RESP n. ${ }^{\circ}$ 41.233/SP, Rel. Min. Eduardo Ribeiro, 22/03/1994; STJ, Terceira Turma, RESP n. ${ }^{\circ}$ 188.318/ES, Rel. Min. Carlos Alberto Menezes Direito, J. 27/03/2000; STJ, Terceira Turma, RESP n. ${ }^{\circ}$ 475.040/MG, Rel. Min. Ari Pargendler, 24/06/2003; STJ, Quarta Turma, RESP n. ${ }^{\circ}$ 158.405/SP, Rel. Min. Barros Monteiro, 21/08/2003; STJ, Terceira Turma, RESP n. ${ }^{\circ}$ 784.273/GO, Rel. Min. Carlos Alberto Menezes Direito, 12/12/2006; STJ, Quarta Turma, RESP n. ${ }^{\circ}$ 274.588/PR, Rel. Min. Luis Felipe Salomão, 19/03/2009; STJ, Terceira Turma, RESP n. ${ }^{\circ}$ 998.460/SP, Rel. Min. Nancy Andrigui, 22/02/2010.

${ }^{618}$ Cf., nesse sentido, F. GigliotTI, Il divieto cit. (nt. 4 supra), p. 38.

619 Também a jurisprudência italiana caminhou nesse sentido, ao reconhecer que a proibição seria aplicável a negócios jurídicos com análogos efeitos práticos e no caso dos contratos atípicos - cf. Cass Pordenone, 21/03/2010, in Giur.it., 2010.

${ }^{620}$ Cf., nesse sentido, L. G. HADDAD, A proibição cit. (nt. 519 supra), p. 23,

${ }^{621} \mathrm{O}$ art. 1.433, I, do Código Civil, e.g., é explícito ao atribuir ao credor pignoratício o direito à posse da coisa empenhada 
Para que o pacto comissório se mostre apto a justificar tão rígido tratamento, à locução "ficar com" deve necessariamente corresponder a transferência de um poder máximo e irrestrito, capaz de gerar um ônus igualmente profundo ao devedor ${ }^{622}$. Por isso, fala-se aqui em transferência da propriedade em sentido amplo, isto é, de titularidade ${ }^{623}$, no sentido ponteano de se tornar titular de patrimonialidade ${ }^{624}$.

Para R. D. F. VANZELLA ${ }^{625}$, relativamente ao conteúdo, três são as principais características dessa titularidade que recai sobre a patrimonialidade: (a) O imediatismo em relação ao poder exercido diretamente sobre a prestação ou o bem objeto da garantia; (b) A oponibilidade erga omnes, que protege de eventuais interferências de terceiros que não sejam o próprio titular - essa regra se aplica tanto aos direitos absolutos de titularidade quanto aos direitos relativos de crédito; (c) A imunidade contra execuções, individuais e coletivas, como o concurso civil de credores ou a falência.

Ainda quanto à estrutura do pacto propriamente dita, os mencionados dispositivos exigem que a sua constituição seja necessariamente anterior ao vencimento da obrigação ${ }^{626}$. Nesse sentido, é possível que sua celebração possa ser simultânea à do negócio jurídico que dá origem à relação obrigacional principal (in continenti), ou a esta posterior (ex intervallo), desde que seja anterior ao vencimento. Também em relação à natureza, não há grandes dúvidas de que, dada sua eficácia translativa, o pacto comissório configura-se como uma espécie de alienação $^{627}$.

${ }^{622}$ Cf., S. NARDI, Appunti in tema di patto commissorio e violazione del principio di solidarietà, in Giustizia Civile - Repertorio generale annuale di legislazione, bibliografia, giurisprudenza, Milano, Giuffrè, 2005, pp. 329 e ss.

${ }^{623}$ R. D. F. VANZELLA, 'Numerus clausus' dos direitos reais e autonomia nos contratos de disposição brasileiro (tese de doutorado em Direito Civil), São Paulo, FADUSP, 2009. pp. 65-67; L. G. HADDAD, A proibição cit. (nt. 519 supra), pp. 23-24.

${ }^{624}$ F.C. PONTES DE MIRANDA. Comentários à Constituição de 1967, t. 5, São Paulo, RT, 1968, pp. 364-369.

625 'Numerus clausus' cit. (nt. 623 supra), pp. 67-70.

${ }^{626} \mathrm{O}$ momento, como se verá adiante, ao analisá-lo conjuntamente com a dação em pagamento, é de crucial importância para a caracterização do pacto - cf. item III.2.4.

${ }^{627}$ Cf., especialmente, C. M. BIANCA, Il divieto cit. (nt. 444 supra), p. 215; S. NARDI, Appunti cit. (nt. 622 supra), pp. 329 e ss. 
Vale lembrar que a caracterização da hipótese do pacto prescinde que o bem objeto da garantia seja de titularidade do devedor. À incidência dos artigos 1.365 e 1.428 do $\mathrm{CC} / 02$ nada obsta, portanto, que a garantia seja prestada por terceiro.

A maior polêmica, contudo, diz respeito à sua função, tema em que se destacam duas principais orientações, representadas com força nas teses de C. M. BiANCA $^{628}$ e F. ANELLI ${ }^{629}$. Respectivamente, de um lado, sustenta-se a função de garantia e, de outro, a função solutória.

A primeira posição, dominante entre os doutrinadores ${ }^{630}$, condiciona a função de garantia à satisfação do interesse do credor. O pacto comissório seria, assim, espécie de alienação com função de garantia, sendo sua nulidade consequência direta da impossibilidade de que semelhante construção possa justificar, sob o viés causal, a transferência da propriedade do bem ${ }^{631}$. Isso porque a questionável qualidade de numerus clausus atribuída aos direitos reais induziria, igualmente, à tipicidade dos negócios que lhes fossem translativos, ainda que sob o escopo garantista ${ }^{632}$.

Dessa inevitável sobreposição entre os conceitos de pacto comissório e de alienação em função de garantia é que então se justificaria a existência do chamado pacto comissório autônomo ${ }^{633}$. Este se diferencia do pacto comissório

${ }^{628}$ Il divieto cit. (nt. 444 supra), p. 153.

${ }^{629}$ L'alienazione in funzione di garanzia, Milano, Giuffrè, 1996, p. 92.

${ }^{630}$ Cf., entre outros, F. MESSINEO, Manuale di diritto civile e commerciale, v. 3, $9^{\mathrm{a}}$ ed., Milano, Giuffré, 1959, p. 100; A. LUMINOSO, La vendita con riscatto - art. 1500-1509, in Il codice civile, P. SCHLESINGER (org.), Milano, Giuffrè, 1968, p. 219; A. SASSI, Garanzia del credito cit. (nt. 4 supra), p. 43; U. CARnevalli, Patto commissorio cit. (nt. 520 supra), p. 505; E. RoPPO, La responsabilità patrimoniale del debitore, in Trattato di Diritto Privato, P. RESCIGNO (org.), v. 19, Torino, UTET, 1985, pp. 433 e ss; S. PUGLIATTI, Precisazioni cit. (nt. 520 supra), p. 298; E. GiacoBBe, Patto commissorio, alienazioni in garanzia, vendita com patto di riscatto e frode alla legge - variazioni sul tema, in Giustizia Civile - Repertorio generale annuale di legislazione, bibliografia, giurisprudenza, Milano, Giuffrè, 1997, pp. 2531 e ss.; V. MARICONDA, Trasferimenti commissori e principio di causalità, in Foro Italiano, Torino, Giappichelli, 1989, p. 1427; G. F. MinNITI, Patto marciano cit. (nt. 489 supra), p. 30.

${ }^{631}$ Cf. S. Pugliatti, Precisazioni cit. (nt. 520 supra) p. 298.

632 A posição é sabiamente contestada por alguns autores, também apoiadores desta corrente, para os quais traria insuportável sacrifício à autonomia privada - cf., entre outros, C. DONISI, Il problema dei negozi giuridici unilaterali, Napoli, Jovene, 1972, p. 56; G. B. FERRI, Causa e tipo nella teoria del negozio giuridico, Milano, Giuffrè, 1966, p. 242; M. ZACCHEO, Gestione fiduciaria e disposizione del diritto, Milano, Giuffrè, 1991, p. 342.

${ }^{633}$ Cf. N. CIPRIANI, Patto commissorio cit. (nt. 256 supra), p. 60. 
em garantia propriamente dito por não estar associado a quaisquer das garantias reais típicas ${ }^{634}$. Por conceder ao devedor idêntica posição de vulnerabilidade, também ele seria considerado ilícito e, portanto, nulo ${ }^{635}$.

A função de garantia destina-se, assim, a reforçar a expectativa de adimplemento por parte do devedor, com a inserção ao negócio de elementos ulteriores àqueles apresentados pelo tipo estruturante legal. Conserva, por essa razão, maior independência em relação à estrutura negocial a que se vincula, não sendo, por si só, suficiente à extinção da obrigação principal ${ }^{636}$.

Contrária a essa posição é aquela segundo a qual o pacto comissório caracteriza-se como uma convenção eventual cujo principal objetivo é o de proporcionar a plena satisfação do credor ${ }^{637}$. Note-se que, ainda que autônoma, se comparada à de garantia, a função solutória conserva maior grau de interdependência à estrutura da relação obrigacional, na medida em que tem por inerente o efeito de extingui-la.

É bastante questionável se esta última posição seria, de fato, a mais adequada a justificar a função da cláusula ${ }^{638}$. Entender o pacto comissório como casualmente autônomo em relação à própria estrutura de garantia e apto a

${ }^{634}$ Em trabalho pioneiro sobre o tema em relação ao direito português, I. ANDRADE DE MAtos delinea um exemplo esclarecedor de pacto comissório autônomo: “' A' empresta 10.000 euros a ' $B$ ' pelo prazo de 6 meses. Como única garantia do reembolso daquela quantia e do pagamento dos respectivos juros, ' $A$ ' $e$ ' $B$ ' combinam que 'A' ficará proprietário de um quadro de ' $B$ ' uma vez decorrido o mencionado prazo de 6 meses sem que ' $B$ ' tenha procedido ao reembolso da quantia mutuada acrescida dos juros acordados” - cf. O Pacto Comissório cit. (nt. 531 supra), p. 79.

Analisando o sistema italiano, E. ROPPO conclui que, se comparados aos pactos comissórios em garantia, os pactos comissórios autônomos têm muito maior aplicação prática, por se encontrarem "ocultos" sob o manto de outros negócios, em regra, de natureza translativa e que desempenham a função de garantia - cf. Note sopra il divieto del patto commissorio, in Rischio Contratuale e Autonomia Privata, Napoli, Jovene, 1982, p. 261.

${ }^{635}$ Esta é a posição sedimentada na doutrina italiana, cujo entendimento apoia-se de forma decisiva na inserção sistemática da norma que prevê a nulidade do pacto comissório no capítulo relativo à responsabilidade patrimonial do devedor (artigo 2.744 do Codice). Daí se retira o argumento de a ratio da proibição justificar a sua aplicação a todos os esquemas negociais e contratuais através dos quais as partes procurem alcançar um resultado econômico proibido pela norma - cf. U. CARNEVALLI, Patto commissorio cit. (nt. 520 supra), p. 502. 156.

${ }^{636}$ Cf. L. BARBIERA, Garanzia del credito e autonomia privata, Napoli, Jovene, 1971, p.

${ }^{637}$ Cf. F. AnElli, L 'alienazione cit. (nt. 629 supra), p. 92; L. BARBIERA, Garanzia del credito cit. (nt. 636 supra), p. 156.

${ }^{638}$ Cf., nesse sentido, N. CIPRIANI, Patto commissorio cit. (nt. 256 supra), pp. 116 e ss. 
extinguir a obrigação principal equivale a elevá-lo à categoria de instrumento alternativo ao adimplemento ${ }^{639}$.

Ademais, em clara violação às regras privadas que genericamente privilegiam o equilibrio contratual, a extinção da obrigação causada pelo pacto comissório prescindiria da valoração da relação entre o montante do crédito e o valor do bem ${ }^{640}$.

Nesse sentido, ao vetar o pacto comissório, portanto, o ordenamento acabou por impedir que as partes dispusessem de um mecanismo de pagamento alternativo ao adimplemento nas situações em que não se verificasse o pagamento ordinário, permitindo, então, a apropriação pelo credor de um bem do devedor, independentemente de qualquer proporção de valor.

Por fim, cabe ressaltar que o pacto comissório e o pacto marciano não se confundem. Este consiste na convenção pela qual, no caso de o devedor não cumprir a sua obrigação na data do respectivo vencimento, a propriedade do bem dado em garantia se transfere para o credor mediante preço justo ${ }^{641}$.

A exemplo de muitos outros ordenamentos modernos vistos alhures, o direito brasileiro considera válida a celebração do pacto marciano, por entenderem que a delegação consensual, a terceiro isento, da tarefa de estimar ou avaliar o bem, após o inadimplemento, afastaria o que há de genuinamente censurável no

${ }^{639}$ Este instrumento pode ser aquele constitutivo da hipoteca, do penhor, da anticrese ou da alienação fiduciária em garantia, mas pode também ser uma alienação a escopo de garantia ou um negócio com estrutura mais complexa - cf. A. SASSI, Garanzia del credito cit. (nt. 4 supra), pp. 67 e ss.

${ }^{640}$ Cf. F. ANELli, L 'alienazione cit. (nt. 629 supra), pp. 303 e ss. O autor colocou em evidência a necessidade de superar o equívoco de identificar a alienação a escopo de garantia com o pacto comissírio autônomo. A alienação em função de garantia, de fato, pode ser realizada sem dever necessariamente recorrer ao mecanismo solutório do pacto comissório - cf. L 'alienazione cit. (nt. 637 supra), pp. 304 -305. No mesmo sentido - cf. N. CIPRIANI, Patto commissorio cit. (nt. 256 supra), p. 141. Contra, S. NARDI, para quem a prédisposição de um mecanismo de pagamento alternativo destinado a operar no caso de inadimplemento do devedor faz do próprio mecanismo uma garantia para o credor e não um instrumento solutório da relação - cf. Appunti cit. (nt. 622 supra), p. 313

${ }^{641}$ Cf., nesse sentido, V. LOJACONO, Il patto commissorio cit. (nt. 204 supra), p. 71. Entre os italianos, aliás, predomina o mais aceito entendimento de que o pacto marciano não se resume a uma modalidade de pacto comissório, consistindo em uma cláusula acessória dos contratos de garantia real a ele totalmente independente - cf., especialmente, N. CIPRIANI, Patto commissorio cit. (nt. 256 supra), pp. 12 e ss. Contra I. ANDRADE DE MATOS, para quem são espécies do gênero pacto comissório o pacto marciano e o chamado pacto comissório desproporcionado, sendo este o único vedado pela lei - cf. O Pacto Comissório cit. (nt. 531 supra), pp. 81-82. 
pacto comissório $^{642}$. Esse entendimento, vale lembrar, já foi aceito de modo expresso em território pátrio, antes do advento do $\mathrm{CC} / 16$, por força das Ordenações Reinícolas (especialmente no Livro 4, Título 56, das Ordenações Filipinas).

\subsection{QUANTO À SANÇÃO}

$\mathrm{Na}$ mesma linha de tantos outros sistemas contemporâneos ${ }^{643}$, o legislador de 2002 trouxe a nulidade como sanção para o descumprimento da vedação ao pacto comissório. Questiona-se ${ }^{644}$, contudo, se tão rigorosa medida seria compatível com a lógica do atual ordenamento privado pátrio.

Afinal, as normas jurídicas que visam à tutela dos contratantes em análoga posição de inferioridade para manifestar seu consentimento, como, e.g., nos casos de erro, dolo, coação, estado de perigo, fraude contra credores ${ }^{645} \mathrm{e}$ lesão ${ }^{646}$, têm como consequência jurídica de seu descumprimento a mera anulabilidade, seja do inteiro negócio jurídico, seja da cláusula avençada ${ }^{647}$.

${ }^{642}$ Cf., nesse sentido, J. C. MoreirA Alves, Alienação fiduciária em garantia, São Paulo, Saraiva, 1973, p. 127; J. M. CARvalHo SANTOS, Código civil cit. (nt. 596 supra), p. 93; A. FraGA, Direitos reaes cit. (nt. 598 supra), p. 121. Na seara jurisprudencial - cf. TJ/SP, 36 Câmara de Direito Privado, Apelação n. ${ }^{0}$ 1120758-0/2, Rel. Des. Romeu Ricupero, 31.01.2008; TJ/SP, $4^{\mathrm{a}}$ Câmara de Direito Privado, Apelação n. ${ }^{\circ}$ 581.973.4/2, Rel. Des. Ênio Santarelli Zuliani, 27.08.2009.

${ }^{643}$ Cf. cap. III.1.

${ }^{644}$ Cf., especialmente, L. G. HADDAD, A proibição cit. (nt. 519 supra), pp. 62-63.

${ }^{645}$ A despeito da dicção legal, a doutrina e a jurisprudência têm sustentado que o que se verifica nos casos de fraude contra credores não é anulabilidade, nas sim ineficácia - cf., entre outros, O. GOMES, Introdução ao direito civil, $12^{\mathrm{a}}$ ed., Rio de Janeiro, Forense, 1996, pp. 431-432. Contra - cf. M. B. DE Mello, Teoria do fato jurídico - Plano da validade, $2^{\mathrm{a}}$ ed., São Paulo, Saraiva, 1997, pp. 168-171. Para uma análise específica da fraude contra credores no contexto falimentar - cf. S. MARCONDES, Da fraude contra credores - falência e alienação de estabelecimento, in Questões de direito mercantil, São Paulo, Saraiva, 1977, p. 125-147; e T. M. VALVERDE, Comentários à lei de falências, v. 1, 4ª ed., Rio de Janeiro, Forense, 1999, pp. 371398.

Sobre o regime jurídico da ineficácia no ordenamento brasileiro - cf. A. JUNQUEIRA DE AZEVEDo, Negócio jurídico - existência, validade e eficácia, São Paulo, Saraiva, 2000, pp. 60-69; e M. B. De Mello, Teoria do fato jurídico - Plano da eficácia, São Paulo, Saraiva, 2003, pp. 6073.

${ }^{646}$ A essas hipóteses acrescentar-se-ia, ainda, o caso de negócio concluído por agente relativamente incapaz - cf. artigo 171 do $\mathrm{CC} / 02$.

${ }^{647}$ Cf., nesse sentido, C. A. MOTA PINTO, Teoria geral do direito civil, $3^{\mathrm{a}}$ ed., Coimbra, Coimbra, 1991, p. 610; O. GoMES, Introdução cit. (nt. 645 supra), p. 473; M. B. DE MELLO, 
Nesses casos, é então possível que, por força da vontade das partes, tais espécies negociais sejam convalidadas, independentemente de sentença judicial. Consequentemente, não constituindo matéria de ordem pública, o vício capaz de sustar a eficácia do negócio não pode ser conhecido de ofício pelo juiz, podendo ser alegado apenas por aqueles que se entendam prejudicados ${ }^{648}$, no primeiro momento possível, sob pena de preclusão.

Pela letra da lei, presume-se, assim, que a nulidade do pacto comissório visa proteger situações que envolvam interesses indisponíveis ${ }^{649}$, insuscetíveis de ulterior confirmação, e podem ser alegadas a qualquer momento, pela parte diretamente prejudicada, por qualquer terceiro que intervenha no feito ou pelo próprio juiz, de ofício ${ }^{650}$. Essa sanção da nulidade, importa lembrar, atinge, por expressa previsão legislativa, tanto o pacto in continenti quanto o pacto ex intervallo.

Complementarmente, os artigos 391 do CC/02 e 591 do CPC, dispondo que o devedor responde pelo inadimplemento com todos os seus bens, presentes e futuros, delineiam a figura da responsabilidade patrimonial. Esta, mesmo não sendo elemento essencial à estrutura da relação obrigacional ${ }^{651}$, representa um fenômeno que lhe é estreitamente conexo.

Por responsabilidade patrimonial se entende o complexo mecanismo pelo qual se faculta ao credor, em razão do inadimplemento, satisfazer-se com a expropriação, por via executiva, dos bens do devedor ${ }^{652}$. Trata-se, portanto, de

Teoria do fato jurídico cit. (nt. 645 supra), pp. 53-55; F. AMARAL, Direito civil - Introdução, $4^{\text {a }}$ ed., Rio de Janeiro, Renovar, 2002, p. 519.

${ }_{648}^{648}$ Cf. artigos 172,174 e 177 do CC/02.

${ }^{649}$ Cf., nesse sentido, STJ, Terceira Turma, RESP n. ${ }^{\circ}$ 41.233/SP, Rel. Min. Eduardo Ribeiro, 22/03/1994.

${ }^{650} \mathrm{Cf}$. artigos 168 e 169 do CC/02.

${ }^{651}$ Cf. P. PERLINGIERI, Manuale di diritto civile, Napoli, Jovene, 2007, p. 210.

${ }^{652}$ Cf. S. Pugliatti, Esecuzione forzata e diritto sostanziale, Milano, Giuffrè, 1935, pp. 87 e ss.; R. Nicolo, L'adempimento indiretto del debito altrui, Milano, Giuffrè 1936, p. 250; R. Nicolo, Responsabilità patrimoniale, in Della responsabilità patrimoniale, delle cause di prelazione e della conservazione delle garanzie reali, R. NICOLO - V. ANDRIOLI - G. GORLA (org.), $2^{\mathrm{a}}$ ed., Bologna-Roma, 1958, p. 54; M. AlLARA, Le nozioni fondamentali del diritto civile, $5^{\mathrm{a}}$ ed., Torino, Giappichelli, 1958, p. 401. 
instituto de direito material que se presta aos fins de uma execução forçada, instituto de direito processual, cuja natureza é evidentemente publicista ${ }^{653}$.

Assim, sendo o poder do juiz de expropriar os bens do devedor instrumental ${ }^{654}$ ao direito privado, tem-se a peculiar situação em que o exercício da faculdade conferida a um sujeito de modificar, para a obtenção de satisfação própria, a esfera jurídica alheia depende de uma função investida ${ }^{655}$. Sem autonomia para, por si só, aperfeiçoar-se, o direito do credor sobre o patrimônio do devedor constitui, mais particularmente, um direito subjetivo expropriativo ${ }^{656}$.

Difundiu-se, assim, a ideia de uma substancial identidade do conceito de responsabilidade patrimonial com o da chamada garantia genérica, geral ou patrimonial $^{657}$. Esta seria um aspecto prodrômico daquela ${ }^{658}$, na medida em que comporta, de um lado, a destinação do patrimônio do devedor à satisfação do crédito e, de outro, a existência a favor do credor de um complexo de poderes sobre o patrimônio alheio.

Nessa perspectiva, importa lembrar que a garantia financeira do direito de crédito ${ }^{659}$ não se confunde com o crédito propriamente dito. Isso porque

${ }^{653}$ Cf. S. Pugliatti, Esecuzione forzata cit. (nt. 652 supra), p. 88.

654 Para uma visão mais abrangente do assunto - cf. C. R. DinAmarCo, $A$ instrumentalidade do processo, $15^{\mathrm{a}}$ ed., São Paulo, Malheiros, 2013, pp. 14 e ss.

${ }^{655}$ Cf. C. M. BIANCA, Diritto civile cit. (nt. 282 supra), p. 102.

${ }^{656}$ Cf. L. BARBIERA, Responsabilità cit. (nt. 520 supra), pp. 45 e ss.

657 Cf. M. FraGALI, Garanzia e diritti di garanzia, in ED 18 (1969), p. 448; F. MASTROPAOLO, I contratti autonomi di garanzia, $2^{\text {a }}$ ed., Torino, UTET, 1995, p. 4.

${ }^{658}$ Cf. F. MASTROPAOLO, I contratti cit. (nt. 657 supra), p. 4.

${ }^{659}$ Os textos jurídicos não trazem uma definição precisa, indistinta e unívoca de garantia, termo bastante polissêmico - cf., nesse sentido, M. GIORGIANNI, L' obbligazione - parte generale delle obbligazioni, v. 1, Milano, Giuffrè, 1968, p. 157; R. NiCOLÒ, Della responsabilità cit. (nt. 652 supra), pp. 42 e ss.; E. BETTI, Teoria generale delle obbligazioni,.v. 1, Milano, Giuffrè, 1955, p. 38; A. MONTEL, Garanzia, in NNDI 7 (1965), p. 354; F. MASTROPAOLO, I contratti cit. (nt. 657 supra), pp. 65 e ss; S. PUGLIATTI, Esecuzione forzata cit. (nt. 652 supra), p. 87. Três são as principais acepções que o termo "garantia" pode assumir no direito privado: (a) como um dos elementos da relação jurídica, ao lado dos sujeitos, do objeto e do fato jurídico - cf. C. A. MotA PINTO, cit. (nt. 647 supra), pp. 182-183; (b) como o patrimônio do devedor ou de outros coobrigados ou corresponsáveis; (c) como os bens destacados do patrimônio do devedor, dos coobrigados ou corresponsáveis - cf., para os dois últimos sentidos, L. G. HADDAD, A proibição cit. (nt. 519 supra), pp. 5-6; J. M. ANTUNES VARELlA, Das obrigações cit. (nt. 532 supra), pp. 420-421. Em sentido semelhante - cf. P. R. MARTINEZ - P. F. DA PONTE, Garantias de cumprimento, $4^{\mathrm{a}}$ ed., Coimbra, Almedina, 2003. pp. 13-14.

Sobre análise dos diferentes sentidos da função, na linguagem jurídica - cf. L. G. HADDAD, Função social do contrato - um ensaio sobre seus usos e sentidos (dissertação de mestrado em em Direito Civil), São Paulo, FADUSP, 2009, pp. 35-51. 
o crédito é o direito a uma dada prestação deduzida no vínculo pessoal, enquanto a garantia do crédito, como dito alhures, é constituída pelo inteiro patrimônio do devedor. Ao binômio débito-crédito se avizinha, assim, o binômio responsabilidade-garantia.

Isso se explica na medida em que a responsabilidade patrimonial constitui-se de modo acessório à relação obrigacional, ainda que à sua estrutura permaneça externa. Em outros termos, não se poderia configurar uma relação obrigacional que prescindisse da responsabilidade patrimonial do devedor e, então, da correspondente garantia genérica para o credor.

Esse, inclusive, é um importante elemento diferenciador entre a garantia genérica e a garantia específica - sendo esta última, de fato, meramente eventual: ainda que possa depender da fonte da obrigação (e.g.: no caso de um privilégio ex lege), não pode constituir-se meramente in re ipsa ${ }^{660}$.

Da parte final do artigo 591, do CPC, tem-se, por outro lado, que as limitações da responsabilidade patrimonial apenas podem resultar da lei, jamais da vontade das partes. É o que ocorre, e.g., em relação aos bens absoluta ou relativamente impenhoráveis de que cuidam os artigos 649 e 650 do CPC.

Eventuais operações de autonomia privada voltadas a derrogar o princípio da responsabilidade ilimitada são, portanto, proibidas e sancionadas através da nulidade ${ }^{661}$. Com isso, questiona-se se também os reflexos da proibição ao pacto comissório poderiam implicar em semelhante limitação, especificamente em relação ao bem dado em garantia.

Por "garantia financeira dos direitos de crédito"entende-se o conjunto que inclui não só a responsabilidade patrimonial (art. 391 do Código Civil e 591 do Código de Processo Civil - Lei n. ${ }^{\circ}$ 5.869, de 11 de janeiro de 1973), o processo de execução (todo Livro II do Código de Processo Civil), as ordens de preferência entre os credores (art. 955 do Código Civil, art. 796 do Código de Processo Civil e artigos 83 a 93 da Lei n. ${ }^{\circ} 11.101$, de 9 de fevereiro de 2005, de ora em diante citada como "Lei de Falências"), a propriedade fiduciária (art. 1.361 a 1.368-A do Código Civil), os negócios fiduciários, as garantias reais (penhor, hipoteca e anticrese), os privilégios gerais e especiais (art. 961 a 964 do Código Civil), e os processos que envolvem concurso de credores de forma geral, incluindo a recuperação, judicial e extrajudicial, a falência e a insolvência civil (esta última disciplinada no art. 748 e seguintes do Código de Processo Civil). - cf. J. L. BULHÕES PEDREIRA, Finanças e demonstrações financeira das companhias - conceitos fundamentais, $2^{\mathrm{a}}$ ed., Rio de Janeiro, Forense, 1989, pp. 137-161.

${ }_{660}$ N. Cipriani, Patto commissorio cit. (nt. 256 supra), pp. 45 e ss.

${ }^{661}$ Cf., nesse sentido, M. B. DE MELlo, Teoria do fato jurídico cit. (nt. 645 supra), pp. 169171. 
Como já exposto, o CC/02 decreta expressamente a nulidade do pacto nos casos de penhor, hipoteca, anticrese e alienação fiduciária em garantia. Assim, a proibição ali trazida em relação às chamadas garantias reais típicas impede o exercício do direito potestativo ${ }^{662}$ do credor, consistente no poder em sentido estrito capaz de, tão somente com base na sanção civil, induzir o devedor a um estado de sujeição.

A proibição revela-se de todo absoluta, indiferente à existência de eventual equivalência entre o valor real do objeto dado em garantia e o montante correspondente à obrigação principal. Em resumo, a convenção comissória é nula ainda que, porventura, o valor do bem dado em garantia seja igual ou menor àquele da prestação garantida ${ }^{663}$.

Cria-se, portanto, uma situação anacrônica: mesmo nas situações em que claramente não há qualquer prejuízo ao devedor, o credor, impedido de exercer seu direito potestativo em relação à garantia específica, apenas poderá obter satisfação através da garantia geral, - que atinge o inteiro patrimônio do devedor, compreendido, inclusive, o bem dado em garantia -, após uma longa fase de execução judicial. Na condição de simples credor amparado por garantia real, deverá submeter-se ao benefício de ordem aplicado à realização dos ativos de $\operatorname{massa}^{664}$.

662 Para alguns autores, como C. A. MotA PINTO e L. G. HADDAD, o sentido supramencionado, em que o inadimplemento exige, para sua reparação, a execução judicial, corresponderia a um poder em sentido amplo. Tais autores identificam um segundo poder, em sentido estrito e potestativo, capaz de sujeitar, por força de lei ou contrato, a parte contrária à instauração, modificação ou extinção de relação jurídica, mediante simples declaração ou manifestação negocial, sem que, para tanto, seja necessariamente formada uma relação jurídica processual - cf., respectivamente, Teoria geral cit. (nt. 647 supra), pp. 188-189; A proibição cit. (nt. 519 supra), p. 81. Inclusive, este último poder, baseado na sanção civil, para C. A. MoTA PINTO seria, diante do estado de sujeição do devedor, uma garantia mais eficaz do que aquela obtida pela via judicial, sujeita à solvabilidade de seu patrimônio - cf. Teoria geral cit. (nt. 647 supra), pp. 188-189. Trata-se de interessante construção, cuja aplicabilidade seria possível caso entendido lícito o pacto comissório.

663 Cf. C. MinNiti, Patto marciano cit. (nt. 489 supra), pp. 29 e ss., C. M. BiAnCA, Il divieto cit. (nt. 444 supra), pp. 98 e ss., V. MARICONDA, Trasferimenti commissori cit. (nt. 630 supra), p. 123.

${ }^{664}$ Neste caso, nos termos do art. 82 da Lei de Falências, seus interesses poderão ser preteridos: (a) por titulares de créditos trabalhistas ou decorrentes de acidentes de trabalho; (b) por outros credores que tenham a lhes proteger os próprios pedidos de restituição; ou (c) por titulares de créditos extraconcursais, identificados nos artigos 67 e 84 da Lei de Falências. Também o fisco, nesses casos, é atendido com prioridade em relação aos titulares de garantias reais. 
Em suma, sendo o bem dado em garantia de valor menor ou igual ao da prestação garantida, não há verdadeira razão para que se verifique a proibição ao pacto - ou, ao menos, que ele seja sancionado com medida tão grave quanto a nulidade. Contrariamente, nessas situações, a vedação trazida pelo CC/02 apenas contribui para aumentar a insegurança do crédito e as dificuldades à sua obtenção, de nada servindo para proteger o devedor de uma situação que lhe seja efetivamente desproporcional.

Caso fosse lícito, segundo L. G. HADDAD ${ }^{665}$, o pacto comissório desempenharia ao menos duas funções imediatas, em benefício da referida garantia financeira dos direitos de crédito:

a) Possibilitaria ao credor, diante do inadimplemento do devedor, invocar a seu favor ação de caráter petitório, dada sua condição de proprietário do bem dado em garantia, e não de mero credor da obrigação principal;

b) Na condição de proprietário do bem, este não mais serviria como parte da garantia geral para a coletividade dos credores - hipótese em que, em caso de falência, o credor poderia ser beneficiado pelo pedido de restituição previsto no art. 85 da Lei n. ${ }^{\circ} 11.101 / 05$.

Por fim, ainda quanto aos efeitos jurídicos hipoteticamente lícitos do pacto comissório, resta ainda dúvida de em que ato estaria plasmada a tradição ou o registro aptos a promoverem a correspondente transferência de propriedade ao credor $^{666}$.

A resposta, obviamente, estaria no desmembramento da posse quando da constituição dos direitos reais de garantia ${ }^{667}$, momento em que o devedor passa

${ }^{665}$ A proibição cit. (nt. 519 supra), pp. 109 e ss.

${ }^{666}$ Considerando-se mero consenso, refletido na celebração de pacto comissório, é insuscetível de operar a transferência da propriedade - cf. artigo 1.267 do CC/02. Nos direitos reais genericamente considerados, como se sabe, o ato apto a esse fim é a tradição do bem, no caso das coisas móveis, ou o registro do acordo de transmissão na matrícula imobiliária, no caso dos bens imóveis - cf. L. C. PENTEADO, Direito das coisas cit. (nt. 599 supra), pp. 260-261.

${ }^{667}$ Cf. L. G. HADDAD, A proibição cit. (nt. 519 supra), pp. 25-26. Sobre o desmembramento da posse, em particular nos penhores em que a posse permanece com o devedor (como, e.g., os penhores rural, industrial, mercantil e de veículos - cf. F.C. PONTES DE MIRANDA, Tratado cit. (nt. 10 supra), pp. 68-69. 
a possuidor direto da coisa ${ }^{668}$. É dela que o pacto comissório extrairia, caso lícito fosse, sua eficácia ${ }^{669}$.

\subsection{PaCto comissório e daÇão em pagamento posterior aO}

\section{VENCIMENTO}

Resquício da datio in solutum voluntaria romana ${ }^{670}$, também a dação em pagamento ${ }^{671}$ consagrada pelos parágrafos únicos dos já exaustivamente mencionados artigos 1.365 e 1.428 do CC/02 representa, em certa medida, a conjugação das máximas clássicas "solutio eius quod debetur" 672 e "aliud pro alio invito creditori solvi non potest" $"$ "673.

${ }^{668}$ Cuida-se, em síntese, da primeira das hipóteses de tradição previstas no parágrafo único do referido art. 1.267 do Código Civil.

${ }^{669}$ Cf. L. G. HADDAD, A proibição cit. (nt. 519 supra), pp. 25-26.

${ }^{670}$ Diferentemente do direito moderno, o direito romano pós-clássico também reconheceu a datio in solutum necessaria, que prescindia do consentimento do devedor - cf., especialmente, F. C. PONTES DE MIRANDA, Tratado cit. (nt. 10 supra), p. 4; M. KASER, Das römische Privatrecht II cit. (nt. 117 supra), p. 442; A. GuARINO, Diritto cit. (nt. 281 supra), p. 720; V. ARANGIO-RuIZ, Istituzioni di Diritto Romano, $14^{\mathrm{a}}$ ed., Napoli, Jovene, 1984, p. 394; P. F. GIRARD, Manuel cit. (nt. 26 supra), p. 686; M. MARRONE, Istituzioni di diritto romano, Palermo, Palumbo, 1989, p. 716; S. Di MARZO, Istituzioni di diritto romano, Milano, Giuffrè, 1938, p. 318; A. BURDESE, Manuale cit. (nt. 281supra), p. 596.

Contra, B. DUSI, para quem é possível haver, modernamente, situações excepcionais de datio in solutum necessaria, especialmente nos casos de execução forçada - cf. Istituzioni di diritto civile, v. 2, 2a ed., Torino, Giappichelli, 1937, p. 61.

Por fim, importa distinguir a datio in solutum, modo extintivo da obrigação, da moderna dação pro solvendo, em que a obrigação apenas é extinta com o pagamento efetivo do título, não tendo o credor o risco da cobrança. Em outras palavras, o devedor entrega o título de crédito apenas para facilitar a sua execução e não para extinguir a dívida - cf., nesse sentido, L. BARASSI, Istituzioni di diritto civile, $2^{\mathrm{a}}$ ed., Milano, Giuffrè, 1945, p. 381; G. CHIRONI, Elementi di diritto civile, Torino, Fratelli Bocca, s.d., p. 197; E. MOLITOR, Schuldrecht I-Allgemeiner Teil, $8^{\mathrm{a}}$ ed., München, C. H. Beck, 1965, p. 134; H. FIKENTSCHER, Schuldrecht, 9a ed., Berlin-New York, Walter de Gruyter, 1997, p. 190.

${ }^{671}$ É curioso notar que A. TEIXEIRA DE FREITAS, em seu Esboço, criou uma nova expressão, denominando a figura por pagamento por entrega de bens, uma vez que privilegiou a utilização da língua portuguesa, apesar da grande profusão do termo datio in solutum - cf. Esboço do Código Civil, v. 1,3, Brasília, Fundação Universitária de Brasília, 1983, p. 261.

Sob a vigência do $\mathrm{CC} / 16$, aliás, era controversa a legalidade do acordo, posterior ao vencimento, destinado a transferir ao credor a propriedade do bem dado em garantia - cf. C. Bevilacqua, Código Civil dos Estados Unidos do Brasil, v. 3, p. 1229. Contra, F. C. PONTES DE MIRANDA, Tratado cit. (nt. 10 supra), p. 29.

${ }^{672}$ Cf. Gai. 3, 168; Inst. 3, 29 pr.

${ }^{673}$ Cf. Paul. 28 ad ed., D. 12, 1, 2, 1. 
À luz do CC/02, tem-se que, após o vencimento da dívida, sendo ainda exigível a prestação, é plenamente admitida a dação em pagamento do bem objeto da garantia, por meio de acordo entre credor e devedor ${ }^{674}$. Consagra-se, portanto, o caso mais comum de dação em pagamento, em que há substituição da prestação pecuniária por coisa diversa ("rem pro pecunia") ${ }^{675}$.

A redação dada ao tema pelo legislador de 2002, aliada às dificuldades na definição de sua natureza jurídica ${ }^{676}$, torna pouco nítida a distinção entre a dação em pagamento e o pacto comissório. Houve, inclusive, quem afirmasse ${ }^{677}$, diante desses dispositivos legais, que o objeto do pacto comissório teria passado a ser lícito no direito brasileiro, desde que concebido para produzir seus efeitos após o vencimento da dívida.

${ }^{674}$ A previsão do instituto no CC/02 apenas corrobora sua fundamental importância no sistema de relações obrigacionais, contrapondo-se às opiniões daqueles que consideram diminuto seu interesse econômico e social - cf., nesse sentido, A. ZACCARIA, La prestazione in luogo deli adempimento -fra novazione e negozio modificativo dei rapporto, Milano, Giuffrè, 1987, pp. 1-2.

${ }^{675}$ Além deste, J. M. CARVALHo SANTOS traz outros oito casos em que é possível aplicar a dação em pagamento em substituição: (a) a uma coisa móvel ou imóvel ao invés de uma outra ("rem pro re"); (b) a um fato ("rem pro facto"); (c) a uma coisa ("factum pro re"); (d) de um fato positivo ou negativo do devedor por outro fato ("factum pro facto"); (e) a dinheiro ("factum pro pecunia"); (f) de um crédito do devedor ou de outra pessoa por uma coisa ("nomen iuris pro re"); (g) a dinheiro ("nomen iuris pro pecunia"); (h) a um fato devido ("nomen iuris pro facto") - cf. Código civil cit. (nt. 596 supra), p. 213.

${ }^{676}$ Sobre o tema no direito italiano - cf., especialmente, S. RoDOTÀ, Dazione in pagamento - diritto civile, in ED 11 (1962), p. 735; C. GRASSETTI, Datio in solutum, in NDI 4 (1938), p. 550; C. M. BIANCA, Diritto civile cit. (nt. 282 supra), pp. 107-108.

Divergências sobre a natureza jurídica da datio in solutum, contudo, estão presentes já no direito romano, entre os sabinianos e proculianos - cf. Gai. 3, 168. Em suma, de um lado, os sabinianos defendiam a tese de que a datio in solutum era uma hipótese de extinção ipso iure da obrigação, ou seja, agia como fato de eficácia no plano da existência da dívida. De outro lado, os proculianos consideravam a dação em pagamento como uma extinção exceptionis ope da obrigação, devendo, assim, o devedor utilizar a exceptio doli mali para paralisar a actio do credor, agindo a dação no plano da eficácia do crédito. O tema é exaustivamente tratado pela doutrina cf., especialmente, M. TALAMANCA, Istituzioni cit. (nt. 71 supra), p. 639; G. AstuTI, Dazione in pagamento - Diritto romano e intermedio, in ED 9 (1962), p. 728; C. LONGO, Datio in solutum Diritto romano in NNDI 5 (1957), p. 173; P. BONFANTE, Istituzioni (nt. 50 supra), p. 423; A. GuARINO, Diritto cit. (nt. 281 supra), p. 720; M. KASER, Das rõmische Privatrecht cit. (nt. 117 supra), p. 638; G. L. FALCHI, Le controversie tra sabiniani e proculiani, Milano, Giuffrè, 1981, pp. 179-182.

Tal controvérsia apenas foi resolvida por Justiniano, que privilegiou a tese sabiniana - cf. Inst. 3, 29 pr. E. C. SILVEIRA MARCHI, analisando o fragmento paralelamente ao de Gai. 3, 168, nota ser o preceito justinianeu mais pungente, por utilizar o termo "obbligatio" em lugar de "omnis obligatio", tendo ainda descartado "praecipue" - cf. Concurso de Credores - e "pactum ut minus solvatur", Lecce, Edizione del Griffo, 1997, p. 47.

${ }^{677}$ Cf. A. G. N. LiQuidATO, O contrato de penhor (tese de doutorado em Direito Civil), São Paulo, FADUSP, 2012, pp. 183-184. Contra - cf. L. G. HADDAD, A proibição cit. (nt. 519 supra), pp. 116-122. 
Grosso modo, ao autorizar que, após o vencimento, o devedor dê ao credor a coisa objeto da garantia, confundir-se-iam os efeitos do pacto comissório com os da dação em pagamento, então suspensivamente condicionados ao inadimplemento da dívida. Nesse sentido, a licitude do pacto se aperfeiçoaria com a aceitação, pelo credor, em "receber prestação diversa da que lhe é devida"678 - o que se estipularia de modo condicionado à impontualidade do devedor no pagamento da prestação ${ }^{679}$. A ideia, contudo, não merece respaldo.

Preliminarmente, importa ressaltar que prevalece no ordenamento pátrio o caráter real da dação em pagamento ${ }^{680}$. Mais do que um instrumento solutório $^{681}$ e oneroso ${ }^{682}$, trata-se de contrato de formação real, que apenas se aperfeiçoa com a traditio da coisa dada em pagamento ${ }^{683}$, com a consequente liberação do devedor. Em outras palavras, sem que haja a transferência do direito de propriedade ou de outro direito, a dação em pagamento não se aperfeiçoa ${ }^{684}$.

${ }^{678}$ Cf. artigo 356 do CC/02.

${ }^{679}$ Cf. A. G. N. LiQuidATO, $O$ contrato de penhor cit. (nt. 677 supra), p. 184.

${ }^{680}$ Cf., especialmente, F. C. PONTES DE MIRANDA, para quem a dação em pagamento é um negócio jurídico bilateral de alienação com eficácia posterior ao fato jurídico de que resulta a dívida - cf. Tratado cit. (nt. 10 supra), p. 3-6. No mesmo sentido, na doutrina estrangeira - cf. S. Rodotà, Dazione cit. (nt. 676 supra), pp. 737-738; C. M. BIANCA, Diritto civile cit. (nt. 282 supra), pp. 438-439 e C. GRASSETTI, Datio in solutum cit. (nt. 676 supra), p. 174-175; F. MESSINEO, Manuale cit. (nt. 630 supra), p. 271; F. Galgano, Diritto privato, 6 ${ }^{a}$ ed., Padova, CEDAM, 1990, p 193.

${ }^{681}$ Cf. S. RoDOtÀ, Dazione cit. (nt. 676 supra), pp. 737-738; F. MESSINEO, Manuale cit. (nt. 630 supra), p. 273.

${ }^{682}$ Cf. S. RodotÀ, Dazione cit. (nt. 676 supra), pp. 737-738; F. Messineo, Manuale cit. (nt. 630 supra), p. 273; C. GrassetTI, Datio in solutum cit. (nt. 676 supra), p. 174-175; R. NiCOLò, Della responsabilità cit. (nt. 652 supra), p. 45.

${ }^{683}$ Cf. F. Galgano, Diritto privato cit. (nt. 680 supra), p 193.

${ }^{684} \mathrm{Tal}$ corrente contrapõe-se a outras tradicionais soluções adotadas pela doutrina, de que a datio in solutum remeteria, especialmente, a: (a) uma novação - cf., entre outros, E. PACIFICIMAZzonI, Istituzioni di diritto civile italiano, v. 4, $5^{\mathrm{a}}$ ed., Torino, UTET, 1927, p. 134; T. HUC, Commentaire théorique e pratique du Code Civil, v. 8, Paris, Cotillon, 1895, p. 46; L. V. L. J. LAROMBIÈRE, Théorie et pratique des obligations, t. 4, Paris, A. Durant et Pedore-Lauriel, 1885, p. 131; L. Josserand, Cours de droit civil positif français, v. 2, $2^{\mathrm{a}}$ ed., Paris, Sirey, 1933, p. 493; E. CASATI - G. RUSSO, Manuale dei diritto civile italiano, Torino, UTET, 1950, pp. 432-433; J. HuET, Traité de droit civil, Paris, LGDJ, 1996, pp. 65-66; (b) compra e venda - cf., entre outros, J. W. HedemanN, Schuldrecht des Bürgerlichen Gesetzbuches, $3^{\mathrm{a}}$ ed., Berlin, Walter de Gruyter, 1949, p. 121; A. VIGIÉ, Cours élémentaire de droit civil français, t. 2, $3^{\mathrm{a}}$ ed., Paris, Librairie Nouvelle de Droit et de Jurisprudence, 1905, p: 720; (c) modalidade de pagamento - cf. L. CuNHA GonçAlves, Tratado de Direito Civil, v. 4, tomo 2, $2^{\mathrm{a}}$ ed., São Paulo, Max Limonad, 1955, pp. 829-830. Quanto a esta última, sobre a contraposição entre a Théorie des Änderungsvertrages e a Théorie des Erfüllungsvertrages e sua aplicação ao BGB - cf. A. HIRATA, Dos efeitos da dação em pagamento no caso de credor evicto, in Revista da FADUSP, Sãoo Paulo, v. 96, 2002, pp. 640642. 
Isso posto, não obstante a notável proximidade entre o pacto comissório e a dação em pagamento no direito brasileiro ${ }^{685}$, duas principais circunstâncias acabam por extremar as duas figuras: o fato de estar ou não a dívida vencida e a existência prévia ou não de ônus sobre o bem.

Quanto à primeira questão ${ }^{686}$, sendo um acordo com efeitos solutórios em relação à obrigação principal, tem a dação em pagamento de avençar-se depois de contraída tal obrigação ou após seu vencimento ${ }^{687}$. O pacto comissório, por sua vez, resulta no acordo sobre a transferência de posição jurídica patrimonial celebrado necessariamente em momento anterior vencimento.

Os dispositivos do CC/02, então, vedam o pacto comissório, com a ressalva de que, em se passando o negócio após o vencimento do débito, a dação em pagamento continua eficaz ${ }^{688}$. Com isso, não seria absurdo entender que a vedação do pacto comissório é dirigida a uma conduta que, substancialmente, corresponde a uma dação em pagamento sob condição suspensiva, de dívida não vencida, cujo objeto é o bem dado em garantia ${ }^{689}$.

A par de todas essas correntes citadas, bastante peculiar é a solução adotada por J. M. ANTUNES VARELLA, que desenvolveu tese própria sobre o tema para adequá-lo ao direito vigente, ao vincular seu estudo a uma categoria preestabelecida pelo meio e pelo fim do ato. Para o autor, a plena compreensão da dação em pagamento deve considerar seu meio, que é a realização de uma prestação diversa da original, mediante acordo entre as partes, e o fim, que é a extinção da obrigação, determinada pela vontade do credor. $\mathrm{O}$ autor estabelece, nesse sentido, um aspecto duplo do instituto, no momento único no qual se realiza o ato - cf. Das obrigações cit. (nt. 532 supra), pp. 208-209.

Ao se referir aos institutos em questão, F.C. PONTES DE MIRANDA fala em "figuras jurídicas parecidas" - cf. Tratado cit. (nt. 10 supra), p. 3.

${ }^{686}$ Já levantada por F. C. PONTES DE MIRANDA, para quem a diferença básica entre o pacto comissório e a dação em pagamento estaria em haver ou não dívida vencida - cf. Tratado cit. (nt. 10 supra), pp. 3-6.

687 Por tal razão, não pode-se confundir a dação em pagamento com as obrigações facultativas e alternativas. Nestas espécies de obrigação, como lembra J. M. ANTUNES VARELLA, o acordo é sempre anterior ao da obrigação, geralmente no momento da constituição - cf. Das obrigações cit. (nt. 532 supra), p. 195. No mesmo sentido - cf. A. VILLAÇA AZEVEDO, Dação em pagamento in ESD 22 (1977), p. 186. F. C. PONTES DE MIRANDA acrescenta ainda que nas obrigações alternativas, assim como nas facultativas, só ocorre dação em pagamento quando o objeto prestado é diverso de ambas as prestações previstas - cf. Tratado cit. (nt. 10 supra), p. 4.

Sobre a impossibilidade de que a constituição de um pacto comissório fora das garantias reais típicas possa ser entendida licitamente como uma obrigação alternativa - cf. V. LOJACONO, Il patto commissorio cit. (nt. 204 supra), p. 97.

${ }^{688}$ Cf. F.C. PONTES DE MIRANDA, Tratado cit. (nt. 10 supra), p. 16.

${ }^{689}$ Cf. L. G. HADDAD, A proibição cit. (nt. 519 supra), p. 122. 
Já a segunda diferença diz respeito à existência prévia ou não de ônus sobre o bem que se pretende entregar. Na dação em pagamento, o bem ou o direito sobre o qual recai o consentimento do credor está livre e desembaraçado, não havendo qualquer vinculação anterior com o adimplemento do débito ${ }^{690}$.

No pacto comissório, por outro lado, a existência do ônus prévio, estabelecido pela garantia real ou fiduciária, é fundamental. O bem sobre o qual recai o pacto comissório é previamente determinado, cabendo ao credor e ao devedor, de comum acordo, atribuir-lhe a específica função de garantir o pagamento da dívida ${ }^{691}$.

\section{A TUTELA DO DEVEDOR NECESSITADO COMO FUNDAMENTO HISTÓRICO DA PROIBIÇÃO DO PACTO COMISSÓRIO}

Com razão, as teses mais tradicionais ${ }^{692}$ reconhecem a constituição de Constantino reproduzida em C. 8, 34, 3 (de 320 d.C.) ${ }^{693}$ como marco histórico da

${ }^{690}$ Cf. F. C. PONTES DE MiRANDA, Tratado Tratado cit. (nt. 10 supra), p. 5.

${ }^{691}$ Segundo L. G. HADDAD, ainda permanece sem explicação o porquê de a lei olhar com desconfiança para a sinceridade dessa concordância antes do vencimento, impondo a nulidade do pacto comissório, e abandonar essa mesma desconfiança, logo após o vencimento, no caso da dação em pagamento - cf. A proibição cit. (nt. 519 supra), p. 120.

692 A posição tradicional é adotada pela quase unanimidade dos doutrinadores brasileiros cf., entre outros, Cf., entre outros, F. C. PONTES DE MIRANDA, Tratado cit. (nt. 10 supra), p. 30; L. R. Pereira, Direito das coisas, v. 2, Brasília, Senado Federal, 2004, p. 21; C. BevilacQUA, Código Civil cit. (nt. 671 supra), p. 1229; T. FulgENCIO, Direito real cit. (nt. 10 supra), pp. 110111; J. X. CARVAlHo de MendonÇA, Tratado cit. (nt. 10 supra), p. 631; CAIO MárIO, Instituições cit. (nt. 7 supra), pp. 209-210; S. RoDRIGUES, Direito civil cit. (nt. 10 supra), pp. 337-338; E. ESPínOla, Os direitos reais cit. (nt. 10 supra), p. 322; S. VENOSA, Direito civil cit. (nt. 10 supra), p. 473; L. C. PENTEAdo, Direito das coisas cit. (nt. 10 supra), p. 437; S. S. Venosa, Direito civil cit. (nt. 10 supra), p. 496 e ss.; MARIA HELENA DINIZ, Curso de direito civil cit. (nt. 7 supra), pp. 500 e ss. No mesmo sentido - cf. M. CostanZA, Sulle alienazioni in garanzia e il divieto del patto commissorio, in GC, 1989, p. 1824; A. LUMINOSO, Alla ricerca degli arcani cit. (nt. 520 supra), p. 219; V. OBERTO, Vendita con patto di riscatto, divieto del patto commissorio e contratto di lease back, in Quadrimestre, Milano, Giuffrè, 1984, pp. 356-357; F. REALMONTE, Stipulazioni commissorie, vendita con patto di riscatto e distribuzione dei rischi, in Foro Italiano, Torino, 
proibição do pacto comissório. Como elucidado no precedente capítulo deste trabalho, de fato, tem-se ali a primeira fonte normativa que oficializa o repúdio às cláusulas que permitam ao credor apropriar-se definitivamente da coisa dada em garantia, após o inadimplemento.

Pecam os mencionados trabalhos, no entanto, a igualmente deduzir, sic et simpliciter, que a ratio condutora de tão severa medida imperial estaria na necessidade de tutelar o devedor hipossuficiente perante os "naturais e habituais "694 abusos dos credores. A questão ganha relevância à medida que, para essa corrente, tal fundamento de raízes romanas teria se estendido aos dias atuais e ainda seria suficiente para, por si só ${ }^{695}$, justificar a regra. A ideia, embora não seja de todo absurda, carece de apropriado respaldo científico.

Como concluído alhures ${ }^{696}$, inexistem, ao menos nas fontes a que temos acesso, quaisquer elementos concretos que permitam concluir pela existência de inconvenientes tão graves ao devedor que tenham podido justificar a nulidade da cláusula comissória. O próprio texto de Constantino, ratificado por Justiniano, não é de grande valia para a resolução do problema, ao apoiar-se tão somente nas vagas expressões "captiones" e "asperitas", insuficientes para que delas seja possível extrair posicionamentos definitivos ${ }^{697}$.

A escassez de fontes, sobretudo decorrente da anterioridade das leis que fixaram a proibição do pacto comissório e a extinção da fiducia em relação à compilação justinianéia, torna o estudo do tema no direito romano um campo

Giappichelli, 1989, pp. 1440 e ss.; F. REALMONTE, Le garanzie immobiliari, in Jus, Milano, Università Catolica del Sacro Cuore, 1986, p. 21; G. PUGLIESE, Intorno alla validità della vendita con scopo di garanzia, in Rivista di diritto civile, Padova, CEDAM, 1955, pp. 1070 e ss.; A. LUMINOSO, La vendita con riscatto cit. (nt. 630 supra), p. 240; M. BUSSANI, Patto commissorio, proprietà e mercato, in Rivista critica del diritto privato, Napoli, Jovene, 1997, pp. 119 e ss.; M. GrondonA, Funzione di garanzia, lease back e trasferimenti vietati, in Notariato, Milano, Giuffrè, 1998, p. 171; V. LOJACONO, Il patto commissorio cit. (nt. 204 supra), p. 39; A. REIS, Processos especiais, v. 1, Coimbra, Coimbra, 1982, pp. 287-288; A. VAZ SERRA, Penhor cit. (nt. 534 supra), p. 217.

${ }^{693}$ Cf. item II.3.1.

${ }^{694}$ Cf. A. VAZ SERRA, Penhor cit. (nt. 534 supra), p. 217.

${ }^{695}$ Cf., especialmente, V. LOJACONO, Il patto commissorio cit. (nt. 204 supra), p. 39.

${ }^{696} \mathrm{Cf}$. item II.

697 Contra, V. LOJACONO, para quem o primeiro termo exprime a fraude e ganância características da lex commissoria, e o segundo denuncia a gravidade do dano a ser suportado pelo devedor - cf. Il patto commissorio cit. (nt. 204 supra), p. 10. 
fértil para as mais diversas conjecturas, reforçadas, e.g., pela tendência geral trazida pelo princípio do favor debitoris, especialmente após o advento do cristianismo, à adoção de medidas sancionatórias menos gravosas ao devedor ${ }^{698}$.

Afastada, assim, a possibilidade de que a referência à regra pósclássica seja suficiente para justificar a atual vedação, resta analisar se, a prescindir de suas raízes históricas, a alegada desproporção prejudicial ao devedor, de fato, justifica-se hodiernamente.

Grosso modo, para que assim se entenda, ao natural estado de inferioridade do devedor deve necessariamente corresponder um benefício desproporcional a favor do credor, que passa a ser proprietário de um bem cujo valor supera o próprio crédito garantido ${ }^{699}$, ainda que seja ele obrigado, ex lege, a restituir o excedente ${ }^{700}$. Nessas hipóteses, em que há evidente prejuízo, o devedor apenas celebraria o pacto comissório em premente estado de necessidade ou sob a coação do credor $^{701}$.

Uma vez mais, questiona-se a necessidade de que semelhantes situações sejam sancionadas com a nulidade, uma vez que a tutela do sujeito que celebra um acordo em estado de necessidade, via de regra, exprime-se no ordenamento brasileiro através da mera anulabilidade ${ }^{702}$. Consequentemente,

${ }^{698}$ Sobre a questão - cf. item II.3.

699 Demonstram preocupação com essa situação em que a desproporção entre o valor do bem e o da prestação possa ser prejudicial ao devedor - cf. G. PUGLIESE, Intorno alla validità cit. (nt. 692 supra), pp. 1070 e ss.; F. REALMONTE, Le garanzie cit. (nt. 692 supra), p. 21; A. LuMINOSO, La vendita con riscatto cit. (nt. 630 supra), p. 240; M. BuSSANI, Patto commissorio, cit. (nt. 692 supra), p. 120; M. GrondonA, Funzione di garanzia cit. (nt. 692 supra), p. 171; V. LOJACONO, Il patto commissorio cit. (nt. 204 supra), p. 39; A. DOS REIS, Processos especiais cit. (nt. 692 supra), pp. 287-288.

${ }^{700}$ Isso porque, não obstante o correspondente valor econômico, tratar-se-iam de bens de natureza diversa, o que poderia ser desfavorável ao devedor - cf. A. VAZ SERRA, Penhor cit. (nt. 534 supra), p. 217.

${ }^{701}$ Cf. V. LOJACONO, Il patto commissorio cit. (nt. 204 supra), p. 41.

702 Como dito alhures, é o que ocorre nas hipóteses de erro, dolo, coação, estado de perigo, lesão e fraude contra credores, e também quando o negócio for concluído por agente relativamente incapaz (art. 171 do cc). Ainda mais próximas ao pacto comissório, no que diz respeito à necessidade de proteção da parte contratual inferiorizada estão as situações de estado de perigo (art. 156 do CC/02) e lesão (art. 157 do CC/02), também sujeitos ao regime das anulabilidades. Há, nestes casos uma significativa incongruência em relação à proibição do pacto comissório. Isso porque, em hipóteses substancialmente idênticas, que implicam na necessidade de proteção do devedor vulnerável, que se vê compelido pelas circunstâncias a avençar o pacto, tem-se diversa disciplina lega aplicável. Para L. G. HADDAD, pela ótica da proteção do devedor, a vedação do pacto comissório nada mais seria do que um caso especial de lesão ou estado de perigo - cf. $A$ 
nestes casos, privilegia-se a autonomia privada, cabendo à iniciativa da parte que se sentir prejudicada a busca pelos remédios judiciais cabíveis ${ }^{703}$, à luz do princípio invitus nemo rem cogitur defendere ${ }^{704}$.

Sancionar o pacto comissório através da nulidade equivale a colocá-lo no mesmo patamar de outras situações bem mais gravosas previstas no art. 166 do CC/02, que determina a nulidade, e.g., de negócios celebrados por absolutamente incapaz ou que tenham por objetivo fraudar lei imperativa.

A regra, ainda, é bastante insuficiente para explicar os casos em que o valor do bem dado em garantia seja idêntico ou inferior ao da prestação. Estes casos, em que parece impossível conceber a existência de um prejuízo real ao devedor, C. M. BIANCA ${ }^{705}$ procurou defender sob a alegação de que o interesse pela proibição do pacto comissório teria, na verdade, caráter geral ${ }^{706}$ e não particular.

Em outras palavras, para o autor ${ }^{707}$, a análise da proibição deve ser considerada em seu aspecto macro, tendo por principal fundamento a prevenção do inevitável dano geral causado pela corrente aplicação da cláusula nas práticas

proibição cit. (nt. 519 supra), p. 66. Sobre as diferenças entre os regimes de nulidade e anulabilidade, de modo geral - cf. M. B. DE MELLO, Teoria do fato jurídico cit. (nt. 645 supra), pp. 53-55; W. FLUME, Allgemeiner Teil des Bürgerlichen Rechts 2 - Das Rechtsgeschäft Enzyklopädie der Rechts uns Staatswissenschaft, Berlin, Heidelberg, 1975, pp. 643-701; L. A. Carvalho Fernandes, Teoria Geral do Direito Civil, v. 2, $3^{\mathrm{a}}$ ed., Lisboa, Universidade Católica, pp. 468 e ss.; C. A. MotA PINTO, Teoria geral cit. (nt. 647 supra), pp. 610 e ss.

${ }^{703}$ Cf. C. M. BiANCA, Realtà sociale cit. (nt. 606 supra), p. 47.

${ }^{704}$ Cf. Ulp. 70 ad ed., D. 50, 17, 156, pr.

705 Il divieto cit. (nt. 444 supra), pp. 215-218; Patto commissorio cit. (nt. 520 supra), pp. 711-721. No mesmo sentido - cf. A. MORACE PINELLI, Trasferimenti a scopo di garanzia da parte del terzo e divieto del patto commissorio, in Giurisprudenza Italiana, Torino, UTET, 1994, p. 70; E. Roppo, Note sopra il divieto cit. (nt. 634 supra), p. 401; R. DE NICTOLIS, Nuove garanzie personali e reali, Padova, CEDAM, 1998, p. 466, M. BUSSANI, Patto commissorio, cit. (nt. 692 supra), p. 127.

706 C. M. BIANCA é bastante vago quanto ao que considera de "interesse geral", enumerando situações que envolvem política de credito, integridade do sistema geral de garantias e preservação da função de garantia exercida pelo patrimônio do devedor - cf. Il divieto cit. (nt. 444 supra), p. 216. Em sentido próximo, U. CARNEVALLI procurou justificar a ratio da nulidade na violação da ordem econômica, por ser o pacto comissório contrário à função da responsabilidade patrimonial, ao sujeitar o patrimônio do devedor ao montante do débito - cf. Patto commissorio cit. (nt. 520 supra), p. 219. Também F. GIGLIOTTI apresentou tese pouco convincente, ao entender que a função da proibição seria a de preservar as garantias típicas, as quais, no caso de excessiva difusão do pacto, poderiam perder sua função econômico-social - cf. Il divieto cit. (nt. 4 supra), p. 122. Trata-se de posições apresentadas de modo superficial e, talvez por isso, bastante isoladas, sequer tendo sido mencionadas pelos autores consultados neste trabalho.

${ }^{707}$ Il divieto cit. (nt. 444 supra), pp. 216-217. 
negociais, e consubstanciador de um sistema inidôneo a exprimir uma adequada sujeição do patrimônio do devedor à função de garantia ${ }^{708}$. A sanção de nulidade, portanto, independeria da apuração concreta de prejuízo a quaisquer das partes ${ }^{709}$.

A tese, contudo, carece de elementos apriorísticos que consigam identificar quais exatamente seriam os danos sociais diretamente causados pela difusão do pacto comissório e capazes de justificar tão enérgica tutela preventiva $^{710}$. Até que sejam apresentados fundamentos sólidos nesse sentido, mais razoável seria conceber a nulidade exclusivamente nas situações em que a desproporção entre o valor do bem e o montante da dívida garantida seja prejudicial ao credor, em respeito ao princípio da conservação dos contratos ${ }^{711}$.

\subsection{OUTROS FUNDAMENTOS POSSÍVEIS}

Superada a tese reducionista que condiciona o fundamento da proibição a infundadas razões históricas, apresentam-se brevemente outras alternativas costumeiramente levantadas por doutrinadores estrangeiros para tentar adequar a sanção de nulidade à moderna configuração privatista. São elas: (a) a repressão à usura e à imoralidade; (b) a inderrogabilidade do procedimento judicial; (c) a tutela da garantia geral de todos os credores (preservação do princípio da par condicio creditorum).

${ }^{708}$ Anteriormente, nesse mesmo sentido - cf. C. VIVANTE, Del contratto di assicurazione di pegno - di deposito nel magazzini generali, in Il codice di comercio commentato, L. BOLAFFIO - A. RocCO - C. VIVANTE (org.), 6a ed., v. 7, Torino, UTET, pp. 523-525.

709 Consequentemente, a posição de C. M. BIANCA implica na necessidade de uma interpretação extremamente ampla do art. 2.744 do Codice italiano, uma vez que, dentro do âmbito da proibição legal do pacto comissório, estariam compreendidas não apenas a alienação suspensivamente condicionada, como também a alienação com efeito translativo imediato, ainda que resolúvel - cf. Patto commissorio cit. (nt. 520 supra), pp. 716-717.

${ }^{710}$ Cf. F. GigLIOTTI, Il divieto cit. (nt. 4 supra), p. 117; G. CRICENTI, I contratti in frode alla legge, $2^{\mathrm{a}}$ ed., Milano, Giuffrè, 2008, pp. 213 e ss.; G. VILLA, Contratto e violazione di norme imperative, Milano, Giuffrè, 1993, p. 126.

711 Sobre a conservação como alternativa às nulidades, através da redução ou da conservação substancial - cf., especialmente, J. A. S. DEL NERO, Conversão substancial do negócio jurídico, Rio de Janeiro, Renovar, 2001, pp. 385 e ss. 


\subsubsection{REPRESSÃO À USURA E À IMORALIDADE}

Foi no ordenamento português, fortemente influenciado pela jurisdição eclesiástica ${ }^{712}$, que a tese ganhou maior destaque ${ }^{713}$. Significativa parcela dos doutrinadores lusitanos ${ }^{714}$ acredita que o fundamento da proibição identifica-se não só com a ratio da norma que genericamente previne a usura ${ }^{715}$, mas também com o mais abrangente fundamento, subjacente à condenação dos negócios usurários, relacionado ao locupletamento do credor nas situações em que o valor do bem dado em garantia é superior ao da dívida.

$\mathrm{Na}$ esteira das críticas tecidas ao longo do item precedente, também a afirmação de que pacto comissório tenha sido vedado por ser usurário e, consequentemente, imoral $^{716}$, desconsidera o fato de que, concretamente, dele possa derivar situação não prejudicial ao devedor. Igualmente, a ideia mostra-se insuficiente para explicar o porquê de a nulidade sancionar indistintamente o pacto, a prescindir de qualquer análise casuística sobre a efetiva desproporção do valor do bem em relação ao crédito.

${ }^{712}$ Cf. I. ANDRAdE DE MATOS, O Pacto Comissório cit. (nt. 531 supra), pp. 62-63.

${ }^{713}$ Diferentemente do que se poderia imaginar, não constitui peculiaridade dos países do direito continental europeu e da América Latina, diretamente influenciados pelas regras de direito canônico. Também no direito norte-americano tem-se notícias de normas proibitivas da usura, inclusive, com reflexos criminais. Sobre o tema - cf. L. G. HADDAD, A proibição cit. (nt. 519 supra), pp. 67-69.

${ }^{714}$ Cf., especialmente, PIREs de LiMA - AntUnes VAREla, Código Civil cit. (nt. 520 supra), p. 718; I. Galvão Telles, Contratos Civis - exposição de motivos, in Revista da Faculdade de Direito da Universidade de Lisboa, v. 9, Lisboa, Faculdade de Direito de Lisboa, 1953, p. 168; A. VAZ SERRA, Hipoteca, in Boletim do Ministério da Justiça, n. 62, Lisboa, 1957, p. 74; E. SANTOS, Curso de Direitos Reais - Direitos Reais de Garantia e de Aquisição, Lisboa, Universidade Livre de Lisboa, 1986, p. 72.

${ }^{715}$ Cf. artigo 1146 do Código Civil português. No direito brasileiro, são regras que proíbem a usura aquelas encontradas: (a) no Decreto n. ${ }^{\circ}$ 22.626/93 (Lei da Usura); (b) na Lei n. ${ }^{\circ} 1.521 / 51$ (Lei dos Crimes contra a Economia Popular); (c) na Medida Provisória n. ${ }^{\circ}$ 2.172-32/01, cuja aplicação prática é bastante insipiente - cf. L. G. HADDAD, A proibição cit. (nt. 519 supra), p. 69. O autor critica ainda o fato de, no Brasil, por força da Súmula n. ${ }^{\circ} 283$ do STJ, as limitações relacionadas ao juros remuneratórios trazidas pela Lei de Usura não serem aplicáveis às instituições financeiras, em especial, às empresas administradoras de cartão de crédito. Esse critério meramente subjetivo escolhido pelo legislador implicaria em uma "falta de coerência valorativa da ordem jurídica brasileira", em que não parece ser possível identificar uma correlação lógica entre a reprovabilidade da conduta e a circunstância de ele ser praticada especificamente por uma instituição financeira - cf. A proibição cit. (nt. 519 supra), pp. 70-71.

${ }^{716}$ Cf., especialmente, V. LOJACONO, Il patto commissorio cit. (nt. 204 supra), p. 55. 
Além disso, se a usura estivesse na base da proibição do pacto comissório, ambos os institutos deveriam ter semelhante tratamento ${ }^{717}$. No entanto, enquanto ao pacto coube a rígida sanção de nulidade, de uma proibição absoluta do pagamento de juros nos contratos de mútuo, evoluiu-se para a permissão da cobrança desses mesmos juros, com relativa flexibilização do que pode ou não ser considerado usurário ${ }^{718}$.

\subsubsection{INDERROGABILIDADE DO PROCEDIMENTO JUDICIAL}

A tese, atribuída a E. BETTI ${ }^{719}$, eleva, a um mesmo plano, o caráter executivo inerente ao pacto comissório e a tutela geral de interesses indisponíveis, ao entender que, em decorrência do princípio da inderrogabilidade do procedimento judicial, não seria possível, mediante simples acordo de vontades, atribuir ao credor o poder de autossatisfação através da apropriação da coisa.

Grosso modo, para o autor, permitir que o credor se satisfaça com a mera transferência da propriedade da coisa dada em garantia após o inadimplemento, sem a necessária intermediação do Estado-juiz - detentor do monopólio da atividade processual executiva, que é a expressão autêntica do

${ }^{717}$ Cf. F. GigliotTI, Il divieto cit. (nt. 4 supra), p. 115.

718 Cf. Cf. F. Giglotti, Patto commissorio autonomo e libertà dei contraenti, Napoli, 1997, pp. 115-116; G. PANDOLFI - G. SCARPELlo - M. STElla RitcheR - G. DALlari, Codice civile - libro della tutela dei diritti illustrato com i lavori preparatori e com note di commento, Milano, Giuffrè, 1941, p. 97. Nesse diapasão, importa lembrar que a EC n. ${ }^{\circ}$ 40/03 modificou a redação do art. 192 da $\mathrm{CF} / 88$ e excluiu do dispositivo, dentre outros, o seu anterior $\$ 3^{\circ}$, que buscava limitar as taxas reais de juros remuneratórios a $12 \%$ ao ano.

É curioso notar que, como já referimos anteriormente, antes da entrada em vigor do Código Civil de 1867, os autores portugueses identificavam a proibição do pacto comissório com o perigo de exploração usurária, mas entendiam que a estipulação de pacto comissório mediante justo preço era admissível, precisamente porque nessa hipótese ta perigo não existia - cf. I. ANDRADE DE MAtos, O Pacto Comissório cit. (nt. 531 supra), p. 64.

719 Su gli oneri e i limiti dell'autonomia privata in tema di garanzia e modificazione di obbligazioni, in Rivista di Diritto Commerciale e del Diritto Generale delle Obbligazioni, v. 29, parte II, Milano, F. Vallardi, 1931, pp. 689-715. No mesmo sentido - cf. M. FrAGALI, Del Mutuo - Arts. 1.813-1.822, in Commentario del Codice Civile IV, A. SialojA - G. BranCA (org.), $2^{\mathrm{a}}$ ed., Bologna, Zanichelli, 1966, p. 240; U. CARNEVAlli, Patto commissorio cit. (nt. 520 supra), p. 501. Contra, especialmente - cf. C. M. BIANCA Il divieto cit. (nt. 444 supra), p. 187; C. VARRONE, Il trasferimento cit. (nt. 520 supra), p. 57.

A teoria de E. BETTI encontrava consenso sobretudo sob a vigência do anterior Codice - cf. U. CARNEVAlli, Patto commissorio cit. (nt. 520 supra), p. 501. 
fenômeno jurisdicional $^{720}$ - representaria uma forma de autotutela ou execução $\operatorname{privada}^{721}$.

Para tanto, adota-se o pressuposto de que à interdição da chamada justiça de mão própria corresponderia um absoluto princípio de inafastabilidade da jurisdição ${ }^{722}$, por força do qual seria inadmissível conceber a realização da garantia sem um correspondente processo. Consequentemente, o pacto comissório, ao admitir a substituição da jurisdição estatal pela autonomia privada, jamais poderia ser considerado lícito, por violar irremediavelmente o sistema de direito público.

Em que pese a generalizada resistência ${ }^{723}$ em aceitar a realização extrajudicial da garantia própria das relações jurídicas de direito privado, há indiscutivelmente casos extraordinários ${ }^{724}$ que fogem à regra da heterocomposição, o que confere relatividade ao princípio da inderrogabilidade. Dentre as diversas hipóteses próprias do ordenamento brasileiro ${ }^{725}$ estão, e.g.,

${ }^{720}$ Cf., especialmente, OvíDIO B. DA SILVA, Ação de imissão de posse, $2^{\mathrm{a}}$ ed., São Paulo, RT, 1997, pp. 18-21; C. NEVES, Estrutura fundamental do processo civil - Tutela jurídica processual, ação, processo e procedimento, Rio de Janeiro, Forense, 1997, pp. 36-37.

${ }^{721}$ Por essa razão, E. BETTI entende igualmente que a proibição estende-se, também, às situações em que uma posição jurídica tem a função de garantia, como, e.g., o direito de retenção cf. Su gli oneri cit. (nt. 719 supra), p. 699.

${ }_{722}$ Cf. E. BETTI, Su gli oneri cit. (nt. 719 supra), p. 701.

${ }^{723}$ Cf., nesse sentido, E. H. O. YoshIKAWA, Execução extrajudicial e devido processo legal, São Paulo, Atlas, 2010, pp. 32 e ss.

${ }^{724}$ A expressão é cunhada por C. R. DINAMARCO, Instituições de direito processual civil, São Paulo, Malheiros, 2004, p. 124.

${ }^{725}$ Esse fenômeno, embora pareça destoar da sistemática geral constante do Código de Processo Civil, está longe de ser um princípio absoluto ou que não possa ser afastado pela lei no direito brasileiro. A fim de contrapor-se à tese de E. BETTI, especificamente no que tange à realidade do ordenamento brasileiro, L. G. HADDAD procura levantar exaustivamente tais hipóteses consideradas extraordinárias, em que admite-se a realização da garantia sem processo cf. A proibição cit. (nt. 519 supra), pp. 82-99. Em resumo, segundo o autor, seriam elas relacionadas a: (a) Desforço imediato e direito de retenção; (b) Direito de vizinhança e servidão; (c) Exceção de contrato não cumprido e compensação; (d) Penhor de créditos e títulos de créditos; (e) Disciplina dos armazéns-gerais, no caso do Decreto n. ${ }^{\circ} 1.102 / 03$; (f) Construção de edificações em condomínio, que pode ser objeto de contratação sob o regime de empreitada ou administração, prevista no artigo 63 da Lei n. ${ }^{\circ}$ 4.591/64; (g) Execuções hipotecárias dos artigos 31 e seguintes do Decreto-lei n. $.^{\circ} 70 / 66$; (h) Execução, pela companhia, de quantias devidas pelo acionista remisso, com aplicação análoga nas sociedades limitadas; (i) Rescisão do contrato de promessa de compra e venda de lote urbano prevista no artigo 32 da Lei 6.766/79; (j) Alienação fiduciária de bens imóveis na Lei n. ${ }^{\circ}$ 9.514/97; (k) Sistema de pagamentos brasileiro, nos casos de restituição do saldo positivo ao participante inadimplente; (1) Execução forçada de acordo de voto assumidas em acordo de acionistas arquivado na sede social, nos termos do artigo 118 , $\S 8^{\circ}$, da Lei n. $.^{\circ} 6.404 / 76$; (m) Desconto de crédito consignado em folha de pagamento, por força dos arts. $1^{\circ}$ e $6^{\circ}$ da Lei 
aquelas relativas à compensação de créditos, em que se atribui poderes coercitivos e coativos ao próprio interessado ou a terceiros chamados a agir em seu interesse.

De modo geral, inclusive no ordenamento italiano de E. BETTI, podese prescindir da atuação do Poder Judiciário como um intermediário necessário para realização das garantias ${ }^{726}$, não havendo razão para que também o pacto comissório possa considerar-se exceção à regra. Sua celebração, vale lembrar, não afasta, sob qualquer hipótese, o direito de ação daqueles que eventualmente se considerem prejudicados.

Além disso, é importante notar que, se esse fosse, de fato, o principal fundamento da proibição do pacto comissório, seria mais razoável que a regra estivesse inserida junto àquelas que disciplinam a responsabilidade patrimonial e a execução do devedor, e não relacionada às que versam sobre os direitos reais de garantia, como sói ocorrer ${ }^{727}$.

\subsubsection{TUTELA DA GARANTIA GERAL DE TODOS OS}

\section{CREDORES}

Defendida por F. CARNELUTTI ${ }^{728}$, a tese considera que à admissibilidade do pacto comissório opõe-se uma inevitável violação ao princípio

10.820/03; (n) Alienação fiduciária no mercado financeiro e de capitais, nos termos da Lei n. ${ }^{\circ}$ $10.931 / 04$.

${ }^{726}$ Cf., nesse sentido, U. CARnevali, Patto commissorio cit. (nt. 520 supra), p. 501. Na doutrina italiana, o principal argumento que critica a tese de E. Betti apoia-se no artigo 1.977 do atual Codice, que disciplina o contrato de cessão de bens aos credores, mediante o qual o devedor pode conferir mandado irrevogável aos seus credores, os quais podem obter satisfação direta dessa liquisação, sem necessidade de recurso às vias judiciais - cf. C. M. BIANCA, Il divieto cit. (nt. 444 supra), p. 187. Quanto à cessão de bens no direito italiano - cf., especialmente, R. MiCCIO, Cessione dei beni ai creditori, in ED 6 (1960), p. 384; F. VASSALI, La cessione dei beni ai creditori, in Trattato di Diritto Privato, n. 13, P. RESCIGNO (org.), Torino, UTET, 1985, p. 397.

Ainda nesse sentido, vem a doutrina italiana admitindo a possibilidade de uma interpretação extensiva das excepcionais hipóteses de realização da garantia sem processo, como ocorre, e.g., com o penhor de créditos - cf. G. BongIORNO, L'autotutela esecutiva, Milano, Giuffrè, 1984, p. 98.

${ }^{727}$ Cf. C. VARRONE, Il trasferimento cit. (nt. 520 supra), p. 57.

${ }^{728}$ Cf. Note sul patto cit. (nt. 520 supra), p. 890; F. CARNELUTTI, Mutuo pignoratizio e vendita con clausola di riscatto, in Rivista di Dirito Processuale, Milano, F. Vallardi, 1946, p. 146; G. Stolfi, Promessa di vendita e patto commissorio, in Foro padano - Rivista di Giurisprudenza e dottrina, Torino, Giappichelli, 1957, p. 767; V. ANDRIOLI, Disciplina 
da par condicio creditorum. Curiosamente, portanto, a ratio da proibição transfere-se subjetivamente da tutela do devedor necessitado ${ }^{729}$ para os outros credores do devedor, que, diante de semelhante acordo, correm o risco de ter excluído um bem à garantia comum de seus créditos, em situação que mais se assemelharia à constituição de uma garantia atípica ${ }^{730}$.

Ao analisar um caso em que a Corte de Apelação de Veneza entendeu ser nula a promessa de compra e venda da coisa empenhada, feita pelo devedor ao credor e suspensivamente condicionada ao inadimplemento, o autor ${ }^{731}$ conclui, em resumo, que o pacto comissório pode lesar os demais credores do devedor em duas principais situações:

a) Sempre que houver desproporção, favorável ao credor, entre o preço de mercado do bem e aquele correspondente à obrigação garantida;

b) $\mathrm{Na}$ ordem de preferência creditícia, nos casos específicos de insolvência do devedor. Tratar-se-ia aqui, então, de matéria de ordem pública, devendo-se entender nulas quaisquer alterações que decorram de disposições meramente contratuais ${ }^{732}$.

intertemporale del patto commissorio e sua applicabilità ai privilegi speciali, in Foro Italiano, v. 67, Torino, Giappichelli, 1942, pp. 954-956; T. MANCINI, Vendita con patto di riscatto e nullità ex art. 2.744 codice civile, in Foro Italiano, Torino, Giappichelli, 1966, pp. 1121 ss.; L. BARBIERA, Garanzia del credito cit. (nt. 636 supra), p. 214.

${ }^{729}$ Há, no entanto, autores que recorrem a uma construção mista, que conjuga a tutela do devedor necessitado aos preceitos da par condicio creditorum - cf., dentre outros, S. PUGLIATI, Precisazioni cit. (nt. 520 supra), p. 316; G. PUGLIESE, Intorno alla validità cit. (nt. 692 supra), p. 1066; E. CAPUTO, Vendita a scopo di garanzia e patto commissorio, in Giustizia Civile, Milano, Giuffrè, 1979 , p. 886.

${ }^{730}$ Cf. F. CARnelutTI, Note sul patto cit. (nt. 520 supra), p. 890

${ }^{731}$ Note sul patto cit. (nt. 520 supra), pp. 487-492.

732 Sobre a ordem de preferência dos créditos - cf. A. BUZAID, Do concurso de credores no processo de execução, São Paulo, Saraiva, 1952, pp. 13 e ss.; F. C. PONTES DE MIRANDA, Comentários ao código de processo civil, t. 11 (arts. 736-795), Rio de Janeiro, Forense, 1976, pp. 426 e ss.; C. Neves, Comentários ao código de processo civil, v. 7 (arts. 646-795). $7^{\mathrm{a}}$ ed., Rio de Janeiro, Forense, 1999, pp. 654 e ss.; H. THEODORO JR., A insolvência civil - Excecução por quantia certa contra devedor insolvente, $5^{\mathrm{a}}$ ed., Rio de Janeiro, Forense, 2003, p. 366.

De modo geral, o direito real de garantia representa uma prioridade do titular na excussão do bem. Essa prioridade, no entanto, não é absoluta. Como lembra, L. G. HADDAD, da conjugação das regras do Código Civil (arts. 955-964), do Código de Processo Civil (art. 769) e da Lei de Falências (arts. 83, 84 e 86, entre outros), tem-se que preferem ao credor titular de garantia real: (a) os beneficiários dos pedidos de restituição, nos termos do art. 149 da Lei de Falências; (b) os créditos extraconcursais listados nos arts. 67 e 84 da Lei de Falências; (c) os créditos passíveis de compensação, de modo geral, imunes ao concurso, nos termos do art. 122 da Lei de Falências; (d) os créditos trabalhistas, por força do art. $449, \S 1^{\circ}$, da CLT; (e) os encargos da massa, por aplicação 
Assim, na hipotética situação de licitude do pacto comissório, a excussão do bem dado em garantia tão somente pela verificação do inadimplemento por parte do devedor poderia prejudicar a observância da ordem legal de preferência dos créditos. Afinal, o credor deixaria de ser mero titular de garantia real para se tornar proprietário do bem.

Os efeitos práticos dessa mudança de posição são evidentes. $\mathrm{Na}$ condição de proprietário, o credor beneficiado pelo pacto comissório estaria autorizado a formular o pedido de restituição previsto no art. 85 da Lei 11.101/95 ("Lei de Falências"). Neste caso, diferentemente do que ocorreria se apenas fosse titular de garantia real, passaria a ter preferência em relação a um mais vasto rol de créditos, compreendidos, e.g., os trabalhistas e tributários.

De igual modo, também os credores normalmente subordinados aos titulares de garantias reais, como aqueles titulares de privilégios especiais ou gerais e os quirografários, poderiam ser prejudicados pela licitude do pacto, nas específicas situações em que o credor por ele beneficiado recebesse bem de valor superior ao montante da dívida ${ }^{733}$.

Ainda, uma vez mais, questiona-se ${ }^{734}$ a rigidez da sanção de nulidade. Isso porque, em hipóteses semelhantes, que igualmente privilegiam a proteção ao crédito e ao processo executivo, como, e.g., nos casos de fraude contra credores (artigos 158 a 165 do CC/02) e de fraude à execução (artigos 592 e 593 do CPC), eventuais violações apenas atingem o campo da eficácia ${ }^{735}$, caso em que é possível a modulação de seus efeitos por decisão judicial.

Deve-se, por fim, observar que essa importante correlação entre a proibição do pacto comissório e o respeito ao princípio da par condicio

analógica do art. 84 da Lei de Falências; (f) os créditos tributários, por força dos arts. 186 e 186 do CTN - cf. A proibição cit. (nt. 520 supra), pp. 105-106.

${ }^{733}$ Cf. F. CARNELUTTI, Note sul patto cit. (nt. 520 supra), pp. 488-489.

${ }^{734}$ Cf. L. G. HADDAD, A proibição cit. (nt. 520 supra), pp. 105-106.

${ }^{735}$ Cf. O. GOMES, Introdução cit. (nt. 645 supra), pp. 431-432; S. MARCONDES, Da fraude contra credores, falência e alienação de estabelecimenti, in Questões de direito mercantil, São Paulo, Saraiva, 1977, pp. 125-147. 
creditorum fica restrita às hipóteses de insolvência do devedor ${ }^{736}$ e de eventual abertura do concurso, civil ou falimentar, de credores $^{737}$. A nulidade do pacto comissório trazida pelo CC/02, no entanto, é muito mais ampla, atingindo também as situações em que o devedor seja solvente - o que, pela lógica desta corrente de ideias, nenhum prejuízo causaria a seus demais credores.

${ }^{736}$ Cf. L. G. HADDAD, A proibição cit. (nt. 520 supra), p. 107; S. MARCONDES, Restituição na lei falimentar e a figura especial do art. $76, \$ 2^{\circ}$, in Problemas de direito mercantil, São Paulo, Max Limonad, 1970, pp. 339-340.

${ }^{737}$ Importa lembrar que na reforma legislativa francesa de 2006, a decisão de extinguir a proibição do pacto comissório veio acompanhada da modificação do direito concursal, precisamente no sentido de tornar a cláusula ineficaz na superveniência de processo equivalente ao de recuperação judicial ou falência - cf. item III. 1. 3 . 


\section{CONCLUSÃO}

A lex commissoria pode ser conceituada como uma espécie romana de pacto acessório com eficácia real, que, após verificado o inadimplemento da obrigação principal, importa para o credor insatisfeito a faculdade de conservar para si, na condição de proprietário, a coisa entregue em garantia.

De antemão, um dos mais graves problemas que se verifica no estudo do instituto diz respeito à escassez de fontes que a ela façam referência direta (cf. item II.1). Tendo declarada sua proibição em momento anterior ao trabalho de compilação de que resultou o Corpus Iuris Civilis, com o agravante da concomitante extinção da arcaica fiducia cum creditore junto aos modos formais de aquisição da propriedade, poucos foram os fragmentos que sobreviveram aos nossos tempos.

Entende-se com relativa segurança que a lex commissoria foi estruturada, inicialmente, sob a forma de condição suspensiva, com a fiducia cum creditore. Inegável, porém, que lhe pudessem ser atribuídos efeitos resolutivos o que na antiga Roma era feito através de uma declaração de vontade acessória suspensivamente condicionada ao adimplemento ou não da obrigação.

A curiosa construção, aliás, não era própria da lex commissoria. A exegese das correspondentes fontes demonstra que semelhante tratamento foi atribuído aos estruturalmente análogos institutos do pactum displicentiae e da in diem addictio, que se localizam em títulos imediatamente anteriores ao da lex commissoria em matéria de venda no Digesto.

A análise da aplicação do instituto na venda, importa salientar, tornase imprescindível a qualquer tentativa de reconstrução histórico-dogmática do instituto junto às garantias reais. Isso porque, dada a mencionada excassez de fontes a ela diretamente aplicáveis, são extraídos da venda elementos que permitem eventuais analogias, especialmente quanto à sua estrutura e objeto (cf. item II.2).

As fontes a que se tem acesso, aliás, não permitem qualquer conclusão exata sobre as razões que, em 320 d.C, levaram Constantino à decisão reproduzida 
em C. Th. 3, 2, 1 - e posteriormente ratificada por Justiniano em C. 8, 34, 3. Diferentemente do que é muitas vezes alegado pela doutrina, os termos "captiones" e "asperitas", trazidos nesses textos, são insuficientes para induzir posicionamentos definitivos.

Essa vagueza sobre a ratio da proibição romana não torna absurda a tese de que, possivelmente, a regra tenha refletido valores outros que não somente aqueles diretamente ligados a inconvenientes concretos que tornassem insuportável, ao devedor, a manutenção do liame obrigacional.

Dentre os fatores externos que teriam contribuído à medida imperial, estaria, e.g, a adoção oficial do cristianismo, cujo influxo de ideias consolidou-se na tendência legislativa de tratar com maior rigidez as regras que pudessem levar ao relativo enfraquecimento de quaisquer dos sujeitos de relações jurídicas. No binômio credor-devedor, esses novos valores foram representados pelo princípio do favor debitoris (cf. item II.3).

Sobre o instituto no direito romano, em resumo, pôde-se concluir que:

a) A gravidade creditada ao instituto costuma relacionar-se ao fato de que, ao credor, fosse facultado ficar com a coisa no caso de inadimplemento da obrigação principal. A transferência da propriedade como forma de garantia, no entanto, já era conhecida pelos romanos desde tempos muito mais remotos, com a mencionada fiducia cum creditore.

b) Por influência da fiducia, também foi a lex commissoria recepcionada pelas novas formas de garantia que surgiram posteriormente, quais sejam, o penhor e a hipoteca. A partir das fontes disponíveis, não é possível, no entanto, precisar em que momento tenha isso ocorrido.

c) Verificado o inadimplemento, ao credor também era facultado resolver unilateralmente o contrato. Diz-se "facultado", pois, obviamente, era possível que, em uma situação concreta, ele preferisse insistir no recebimento da prestação principal. Caso optasse por uma ou outra coisa, no entanto, não mais poderia voltar atrás em sua decisão - a exemplo do que ocorria com a lex commissoria em matéria de venda. 
d) Com o incremento das relações comerciais, ao lado da lex commissoria eram utilizados outros meios que também implicavam na perda da propriedade da coisa pelo devedor, como, e.g., o ius distrahendi, a venda da coisa ao credor, acordos similares à anticrese, o pacto marciano e a datio in solutum. Por não implicarem, contudo, a possibilidade de que o devedor pudesse ficar com a coisa para si, essas formas não só não contaram com o repúdio dos romanos, como continuam a serem amplamente aplicadas hodiernamente.

Com o renascimento do direito romano e o posterior movimento codificador, a regra, ratificada também pelo direito canônico, foi amplamente reproduzida nos códigos modernos, inclusive o brasileiro. De fato, ainda hoje, a proibição ao pacto comissório é a regra nos principais ordenamentos que comungam da tradição do direito europeu continental (cf. item III.1).

Há, indícios, no entanto, de que essa regra começa a sofrer erosões. Foi o que ocorreu na França, onde, desde 2006 e sob precisas condições, o pacto é admitido nas relações negociais. O exemplo é importante na medida em que demonstra ser possível entender pela validade do pacto, sem que, para isso, seja causado um desequilíbrio insuportável pelas partes.

De qualquer modo, ainda que pela validade não se queira entender, certo é que a sanção de nulidade adotada pelo CC/02 parece contrariar a lógica do ordenamento em relação a casos semelhantes, em que também se procura proteger a parte mais frágil, como, e.g., nos casos de dolo e fraude contra credores sancionados com a mera nulidade. Como se procurou demonstrar (cf. item III.2), a opção por tão severa punição não se justifica nas situações em que o valor do bem dado em garantia seja inferior ou idêntico ao da prestação.

$\mathrm{O}$ estudo do instituto do $\mathrm{CC} / 02$ aliado às suas origens romanas ganha ainda maior relevância quando se tem em conta que, para a quase unanimidade da doutirna brasileira, o principal fundamento da proibição reside nos naturais inconvenientes que a licitude do pacto causaria ao devedor. Isso, fundamentam, já se teria sentido no período pós-clássico romano e, por essa razão, Constantino adotou a severa medida de nulidade. 
A tese é ultrapassada e fruto de pouca dedicação ao estudo do tema. Diferentemente de outros países, dos quais destaca-se a Itália, em que há décadas a proibição da cláusula comissória vem sendo questionada, o ordenamento brasileiro ainda carece de estudos aprofundados que possam repensar a medida.

Sem a presunção de apresentar uma solução ao problema, ao afastar a ideia amplamente reproduzida pela doutrina brasileira de que a regra contida nos artigos 1.428 e 1.365 do CC/02 justifica-se pelo ônus excessivo de que foi vítima o devedor romano, pretendeu o presente trabalho ser um mero convite à reflexão sobre as razões que, de fato, poderiam justificar a hodierna proibição ou não da medida.

Dentre essas, exaustivamente levantadas por doutrinadores estrangeiros (cf. item III. 3) estariam: (a) a repressão à usura usura e imoralidade da regra; (b) a inderrogabilidade do procedimento judicial; (c) a subtração de bens à garantia geral de todos os credores, com a consequente proteção ao princípio da par condicio creditorum.

Qualquer análise valorativa sobre seu conteúdo, no entanto, extrapolaria os limites exegéticos aqui estabelecidos. Os pontos brevemente levantados na última parte desta dissertação (cf. item III), sobre a proibição no pacto comissório no $\mathrm{CC} / 02$, tiveram sua razão de existir tão somente para melhor elucidar sua conexão com as fontes romanas. 


\section{ÍNDICE DE AUTORES}

ACUTIS

$3,64,79$

ADELLE 125

Albaladejo

AlbANESE $.60,61,67$

ALbERTARIO 3, 31, 32, 34, 35, 46, 79, 93, 95, 98, 99, 102, $104,105,106$

AlLARA 140

Almeida COSTA .115

AMARAL 129,140

AMARAL NETO 129

AMBRosino 13,14

ANDORNO 118

ANDRADE DE MATOS 115, 116, 117, $137,138,154,155$

ANDRIOLI $112,140,157$

ANELLI $2,136,137$

ANGELONI .113

ANKUN .87

ANTUNES VARELA ........115, 141, 148 ARANGIO-RUIZ 13，15，27，57，58, $60,62,63,64,66,67,70$, $71,88,105,147$

ARCANGELI . .30

ARCHI 57, 58, 60, 61, 62, 64, 67, 70, $71,77,88,93$

ASCOLI .......11, 12, 15, 20, 23, 33, 78 ASTUTI 146
AVENA-ROBARDET .125

AYNÈS 125,126

BACHOFEN 46,107

BARASSI .145

BARBIERA $.112,137,141,158$

BECHMAN .58

BEHRENDS .80

BEKKER .30

BELLOCCI $13,15,23$

BENEDEK .19

Bernardes De Mello 139, 142, 152

BERTHELOT 10,80

BESELER $.51,53,55,88$

BETTI 19, 60, 65, 71, 74, 88, 112, $113,141,155,156,157$

BEVILACQUA $3,145,149$ BIANCA 2, 61, 95, 100, 104, 108, 109, 112, 113, 132, 135, 136, 141, 143, 146, 147, $152,153,157$

BIANCHINI .92

BIONDI 8, 9, 19, 20, 22, 26, 51, 65, $66,90,91,93,94,95$ BISCARDI 3, 7, 44, 45, 50, 56, 59, 60, $79,82,83,84,85,87,88$, $89,91,92,95$

BOLAFFIO 153 
Bonfante $1,13,14,52,53,57,58, \quad$ Carvalho Santos 129, 130, 139,

$$
65,72,146
$$

BONGIORNO .157

BORDA 118

BREAUCHET 42,44

BREGLIA $95,96,101,103$

BROGGINI 8,97

BRUGGI $.112,113,114$

BULHÕES PEDREIRA 142

BuRdeSE 3, 8, 14, 23, 25, 26, 27, 28, $29,30,31,38,39,40,42$, 46, 47, 48, 49, 50, 55, 59, $60,76,77,78,79,81,82$, $83,85,86,87,88,90,91$, 95, 101, 103, 104, 107, 108, 109, 110, 145

BUSSANI ...2, 121, 122, 150, 151, 152

BUZAID 158

CAIO MÁRIO $2,3,129,149$

Calboli .31

CALONGE $60,71,74$

CANNATA 19,60

CAPUTO 158

CARASSAI .93

CARDILli .37

CARNELUTTI $112,113,158,159$

CARnevali 112, 113, 136, 137, 152, 155,157

Carvalho de Mendonça .......3, 149

CARVALho FERnANDES 115,152 146

CARValhosa 128

CASATI 147

CERAMI .65

CERVEnCA .92

CHADEL 46,49

ChalHub 129

CHAMPEAUX .38

CHEMIN-BOMBEN 125

CHINÈ 132

CHIRONI $112,114,143$

CIPRIANI 2, 55, 104, 106, 113, 114 , $136,137,138,142$

CLAPS .32

CLARK 8,9

COELHO DA ROCHA 117

COLLINET .23

COMPARETTI .42

COOPER 123,124

CORRADINI .7

CORRÊA TELLES 117,154

CORREIA .92

CostA $8,12,43,44,45,104$

CostanZA 149

CRICENTI .154

CRIFÒ .93

CROCQ 125,126

Cubeddu 112

CunHa Gonçalves 115,147 
D'Ors 1, 10, 57, 60, 61, 62, 63, 64, $65,71,88,89$

DA PONTE .141

DALLARI 155

DALMARTELLO .23

DAUBLON 125

DE CICCO .106

DE FRANCISCI $.19,46,50,51,93$

De Martino . .93

De NiCTOLIS 113,152

DE RUGGIERO . .42

De SENARCLENS 105

DEL NERO 153

DELVINCOURT 125

DERNBURG $46,55,99,107,108$

DeVILla $.48,49,51,52,53,54$

DI MARZO 145

DIAS FERREIRA .115

DINAMARCO 141,156

DIRKSEN .7

DONELLI ..7, 8

DONISI 136

DOVERI .7

Du CANGE .7, 8

DUSI 145

EBRARD $.51,53$

EHRHARDT 19

EISELE $51,57,58$

ENNERCCERUS 121

ERBE ....8, 11, 20, 27, 28, 78, 87, 110

ERNOUT ..7, 8
ESPÍNOLA 3,149

FACHIN 129

FADDA 64,92

FALCHI 146

FAZENDA MARTINS 115,116

FELIÚ REY 119,120

FERRI 136

FERRINI 38,51

FIKENTSCHER 145

FIORI .65

FLUME 152

FRAGA $129,130,131,139$

FRAGALI 141,156

FREMEAUX 125

FREZZA 9, 11, 12, 13, 14, 15, 19, 20, $21,23,27,31,35,36,37$

FUENTESECA 12, 13, 14, 15, 18, 23, 26

FULGENCIO $.3,129,149$

GAFFIOT .99

GALGANO 147

GALLO .38

GALVÃo TELLES 117,154

GARCIA DEL CORRAL ...10, 70, 80, 84 GARCÍA GARRIDO 15

GARCÍA GOYENA 119,120

GAROFALO 14,30

GARRIDO 118

GEIB .20

GiACOBBE 136

GIGLIOTTI .2, 132, 134, 152, 153, 155 
GILMORE 123

GIORGIANNI .141

GIRARD 8, 10, 22, 38, 51, 53, 64, 79, 145

GOLDSCHMIDT 119

GoODE 123

GRADENWITZ $25,27,42,43$

GRASSETTI 146,147

GRONDONA 150,151

Grosso ......19, 47, 48, 60, 65, 66, 79

GUARINO ..60, 61, 104, 105, 145, 146

GUTIÉRREZ FERNÁNDEZ 119

HADDAD 112, 115, 117, 119, 121, $122,125,128,130,132$, 134, 136, 137, 142, 143, 144, 145, 146, 148, 149, 151, 154, 156, 158, 159, 160

HAENEL 24,25

HAYMANN .88

HEBERT 125

HEDEMANN 147

HEIMBACH .67

HELLERSTEIN .123

HENLE $58,63,66,77,88,89$

HERZEN $.8,33,40,78,79,101$

HEUMANN 7, 101

HIRATA 147

HITZIG $42,44,45$

HUC 147

HUET 147
HULOT ……...............................10, 80

HUSCHKE ................................ 7, 101

ITURRASPE ..................................119

JACQUELIN .................22, 23, 25, 46

JOSSERAND ..................................147

JUNQUEIRA ....................................139

KASER 8, 19, 23, 28, 30, 39, 40, 60, $67,83,97,145,146$

KIENINGER $.121,122$

KIPP 121

KNÜTEL .80

KRELLER $20,33,78$

KRÜCKMANN .88

KRÜGER .95

KUNKEL $28,38,39$

KUPISCH 80

LA PIRA 32

LAMBERTINI .19

LAMBRINI ...11, 12, 13, 17, 21, 13, 26

LAROMBIÈRE 147

LASCIALFARI 132

LEICHT 105

LENEL 13, 19, 22, 23, 65, 82, 83, 86, $87,104,108$

LEONHARD .76

LEVY 58, 62, 64, 69, 70, 71, 72, 75, $77,81,85,86,88,89$

LIARD 125,126

LIQUIDATO 146,147

LOJACONO 2, 44, 58, 59, 90, 91, 92, 95, 96, 97, 98, 100, 101, 
$103,112,113,138,150$, 151,154

LONGO 3, 7, 11, 12, 13, 14, 15, 17, $18,23,29,46,47,48,56$, 57, 58, 69, 70, 71, 79, 83, $85,86,87,91,146$

LUMINOSO 112, 113, 136, 149, 150, 151

MADEIRA .105

MAFFEI $.61,64$

MAGNI 132

MAHAFFY ..8

MANCINI 158

MANIGK 14, 26, 32, 42, 50, 55, 101, $102,103,108,110$

MANRESA Y NAVARRO 119

MARCADÉ 125

MARCHESE .13

MARCONDES $.139,159,160$

MARIA HELENA DINIZ $2,6,149$

MARICONDA 136,143

MARRONE .145

MARTINEZ 116,141

MASCHI $.94,95$

MASI $60,71,73$

MASTROPAOLO $.2,141$

MAZZARINO .31

MCCORMACK $122,123,124$

MEILLET $.7,8$

MELILlO $10,65,66$

MENDES .116
Menezes CAmpos 115

MENEZES CoRDEIRO ..... 14, 115, 133

MEssina VitRANO 51,53

MESSINEO 136,147

MICCIO 157

MICHEL 34,89

MINNITI $106,136,143$

MIRABELLI 112,114

MitTEIS .55

MOLITOR 145

MONACI .93

MONNIER $. .7,14,64$

MONTEL 141

Morace PINELLI .152

Moreira Alves 1, 2, 49, 72, 93, 129, 133139

Mota Pinto ........152, 139, 141, 143

NARDI 135,138

NEVES 156,158

NICOLO $140,141,147$

NOORDRAVEN .25, 39, 40, 84, 85, 87

NÖRR 13,14

OBERTO 149

OERTMANN $13,14,23$

ORESTANO $60,64,71$

ORLANDIS ROVIRA .119

ORLANDO GOMES 1, 2, 129, 133, 139,159

Отто .10

OvíDIo 156

PACIFICI-MAZZONI 147 


\begin{tabular}{|c|c|}
\hline 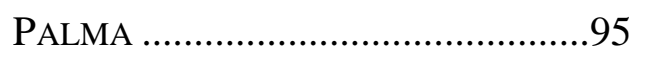 & REIS $\ldots \ldots \ldots \ldots \ldots \ldots \ldots \ldots \ldots \ldots \ldots \ldots \ldots \ldots \ldots \ldots \ldots$ \\
\hline 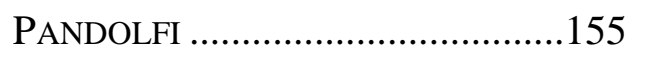 & REMÉDIO MARQUES ......................115 \\
\hline PAOLI ….............................. 42,4 & RESTIFFE ..... \\
\hline PENNITZ _........................................... & RESTIFFE NETO .............................129 \\
\hline PENTEADO .........3, 123, 130, 144, 149 & 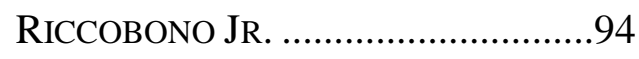 \\
\hline PEREIRA _........................................ 149 & RIVA ........................... \\
\hline PERLINGIERI ........ & ROCCI .............. \\
\hline 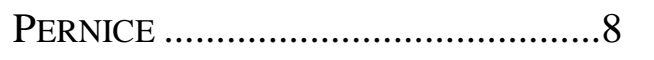 & ROCCO ....................... \\
\hline PEROZZI .....................................51 & RoDOTÀ …...........................146, 148 \\
\hline PETERS .......58, 62, 63, 66, 69, 72, 75 & RODRIGUES BASTOS .............115, 116 \\
\hline PICONE & ROPPO …....................136, 137, 152 \\
\hline PIEDEACASAS .................................. & ROTONDI ................. \\
\hline 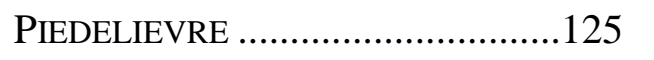 & RUBINO ....... \\
\hline 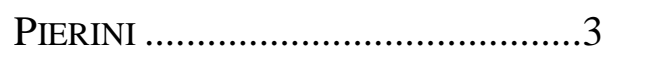 & RUI PINTO ....116, 139, 141, 143, 152 \\
\hline PINTO DUARTE .............................116 & RUSSO .......................................147 \\
\hline PIRES DE LIMA ............115, 116, 154 & SACCHI ............... $3,21,24,29,65,79$ \\
\hline PITTERI ................... & SANTANGELO .......... \\
\hline PONTES DE MiRANDA 3, 133, 135, & 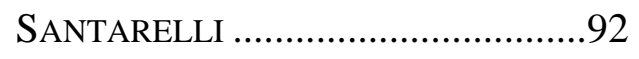 \\
\hline $144,145,147,148,149$ & 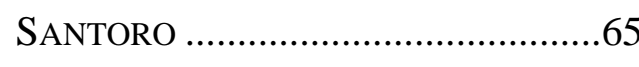 \\
\hline 158 & 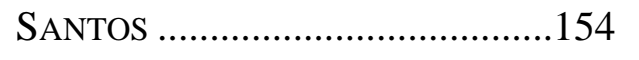 \\
\hline POVEDA VELASCO ..................93, 128 & SARGENTI .........31, 33, 35, 36, 37, 39 \\
\hline PugliatTI ....112, 136, 140, 141, 158 & SASSI $\ldots \ldots \ldots \ldots \ldots \ldots \ldots \ldots \ldots \ldots \ldots \ldots \ldots$ \\
\hline PUGLIESE $19,33,60,61,109,150$, & 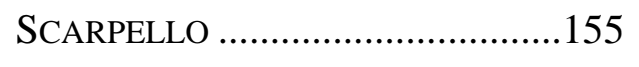 \\
\hline 151,158 & 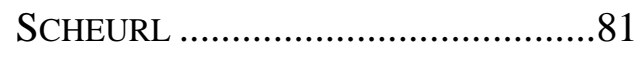 \\
\hline QueIROZ DE MoraES 56, 58, 60, 61, & 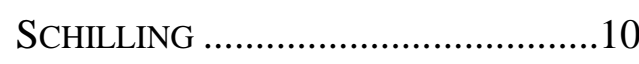 \\
\hline $66,67,68,69,73,75,76$ & SCHIPANI ................... $80,83,84,128$ \\
\hline 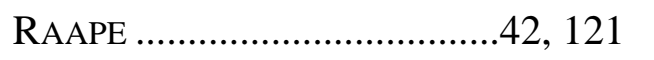 & SCHULZ ........................... 22, 25, 94 \\
\hline RABEL …...........29, 42, 51, 108, 110 & SCIALOJA ….......................... 64 \\
\hline 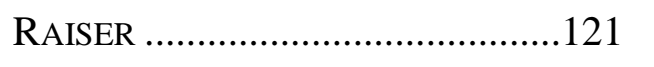 & 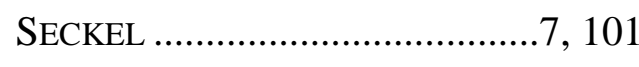 \\
\hline REALMONTE ................149, 150, 151 & SEGRÈ ...................19, 26, 46, 47, 85 \\
\hline REGLERO CAMPOS ...............119, 120 & SEILER ....... \\
\hline
\end{tabular}




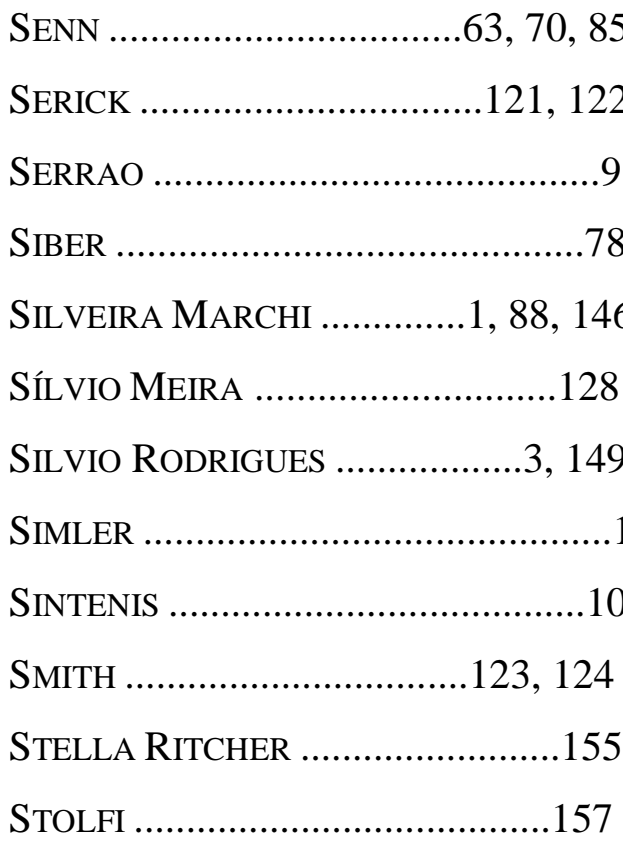

TALAMANCA $14,19,33,37,38,51$, $58,60,61,62,64,66,67$, $69,89,104,105$

TEIXEIRA DE FreITAS ...128, 129, 145

TEPEDINO ....................................129

THEODORO JR. .............................158

TIBILETTI .......................................8

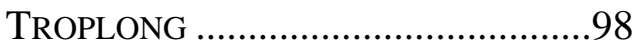

VALVERDE ....................................139

VANZELLA .....................................135

VARRONE ...................112, 155, 157

VASSALLI .......................................60

VAZ SERRA ...........116, 150, 151, 154

VÉLEZ SARSFIELD 119

VENOSA $.2,3,6,149$

VIALE SALAZAR 118

VIGIÉ 147

VIGNALI 10,80

VILLA 153
VILLAÇA AZEVEDO 148,139

VISKY 105

VITELLI $41,42,43$

VIVANTE 114,153

VOLKMAR $. .7,101$

VOLTERRA .60

VON LÜBTOW ...................................76

WALLON .........................................94

WARREN 123

WATSON $10,12,13,15,23,83$

WEISE 123,124

WESSELY 42,43

WESTBROOK

123

WIEACKER 3, 57, 58, 59, 62, 63, 64, 70, 72, 73, 75, 77, 79, 88, 91

WINDSCHEID .................................64

WOLF ........................................121

YosHIKAWA ...................................156

ZACCARIA .....................................146

ZACCHEO ……..................................136

ZIMMERMAN …..........................10, 69

ZINGALE ......................................29

ZINNECKER ................................. 123 


\section{ÍNDICE DE FONTES ${ }^{738}$}

\section{FonTES JURÍDICAS ANTIGAS}

\section{A. Pré-justinianéias}

C.Th. $1,1,3$

C.Th. 3,1 97, 99

C.Th. 3, 2, 1 $4,59,90,91,95,96$

C.Th. 8,16

Coll. 10, 2,2

F.V. 9 21,110

F.V. 14 .75

F.V. 18 .17

F.V. 283 .72

Gai. 2, 60 .21

Gai. 2,64 51,54

Gai. 3, 168 145,146

Gai. 3, 201 .21

Gai. 4, 147 .37

Gai. 4, 62 .13

Gai. 9 22

Gai. 10 .22

P.S. 2, 13 $.21,24$

P.S. 2, 13, 4 .56

P.S. $2,13,6$ .16

P.S. 2, 17 .25

P.S. 2, 5, 1 $.48,53$

\footnotetext{
${ }^{738}$ Excluem-se desse rol as fontes jurídicas modernas. Para as demais, segue-se, em linhas gerais, o modelo adotado por M. KASER - cf. Das römische Privatrecht I cit. (nt. 119 supra), pp. 795 e SS.
} 


\section{B. “Corpus Iuris Civilis"}

\section{Instituciones}

Inst. $3,14,4$

Inst. 3, 29 pr. 145,146

Inst. 4, 6,7

\section{Digesta}

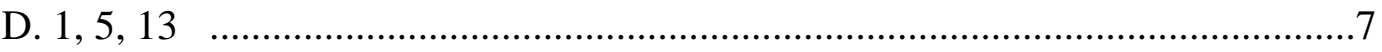

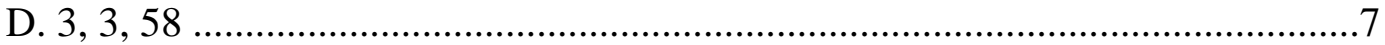

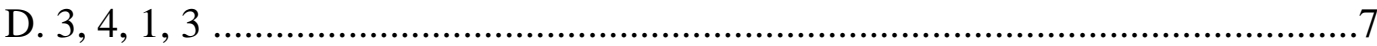

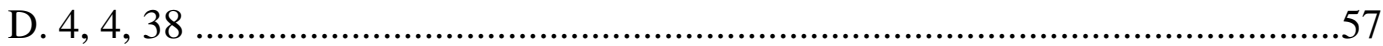

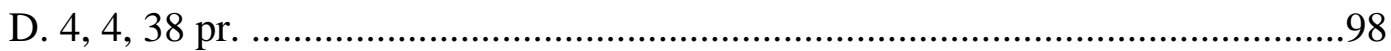

D. $4,9,1,2$,

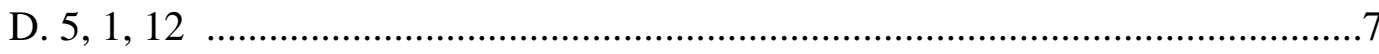

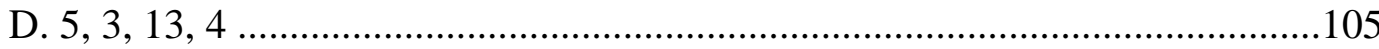

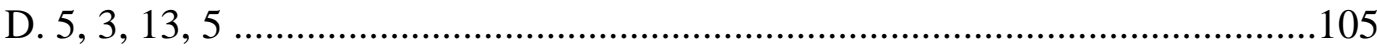

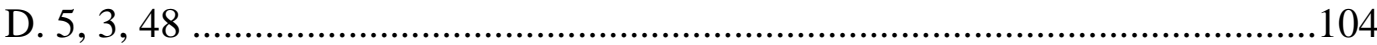

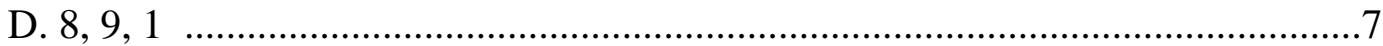

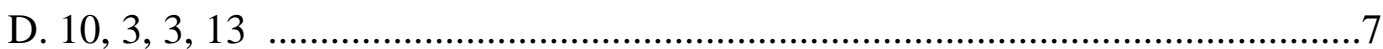

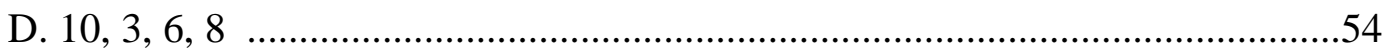

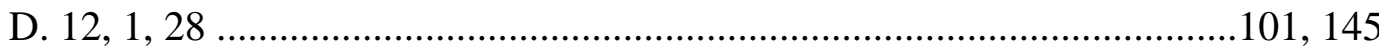

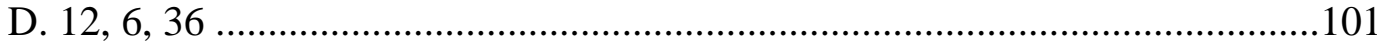

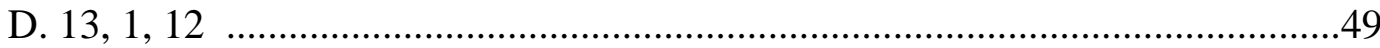

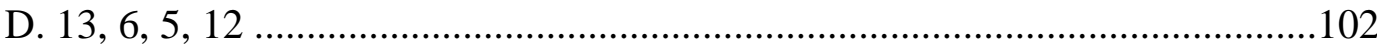

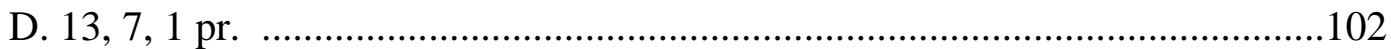

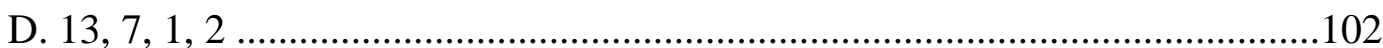

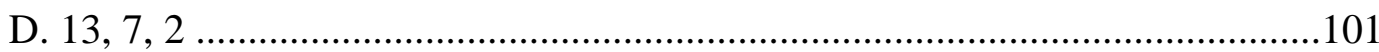

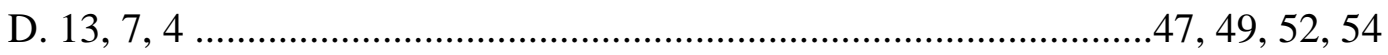

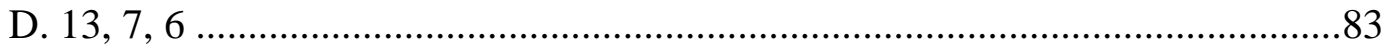


D. $13,7,6$ pr.

$25,29,39,40,46,47,56,83,84,85,87$

D. $13,7,6,1$ .47

D. $13,7,8$ .83

D. $13,7,8$ pr .47

D. $13,7,8,1$ .47

D. $13,7,8,2$ .47

D. $13,7,8,3$ $.47,86$

D. $13,7,8,4$ .47

D. $13,7,8,5$ .47

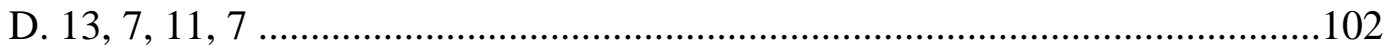

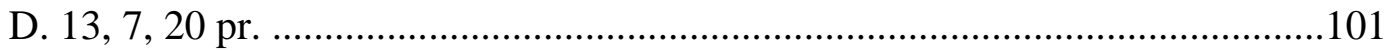

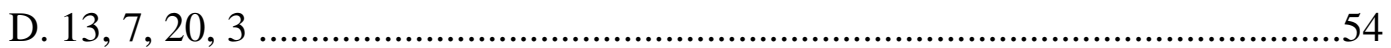

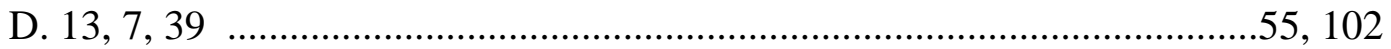

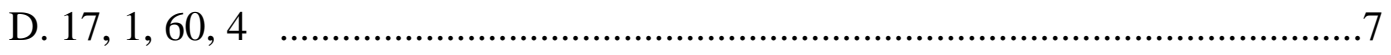

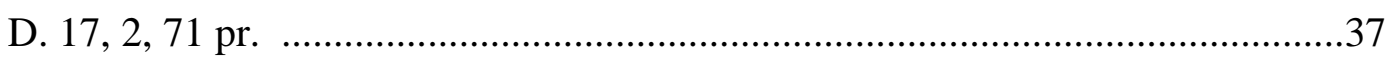

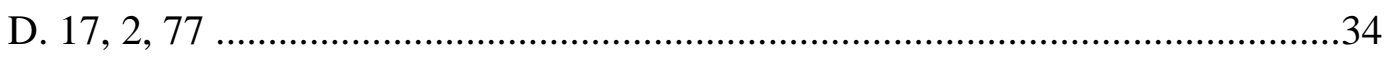

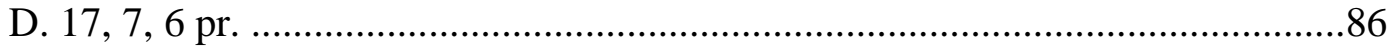

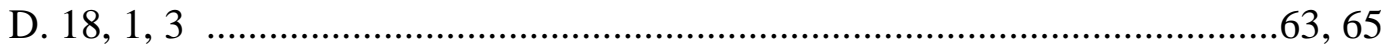

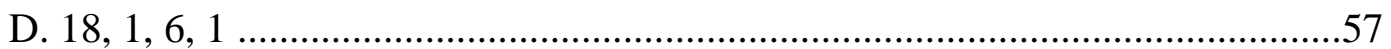

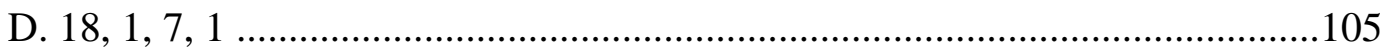

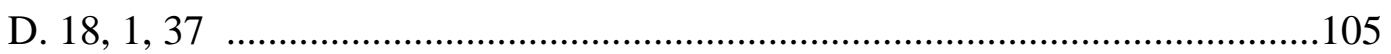

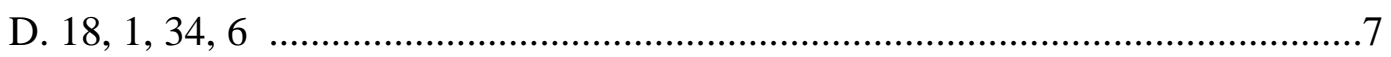

D. $18,1,81$ pr. ................................................................. 99, 108, 109

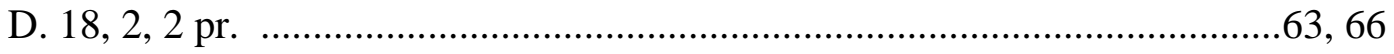

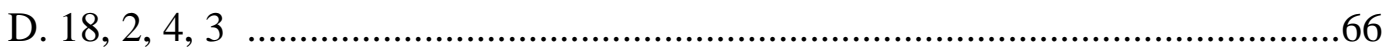

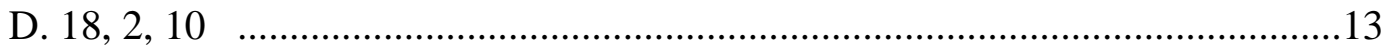

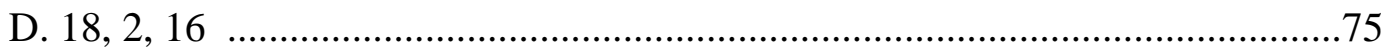

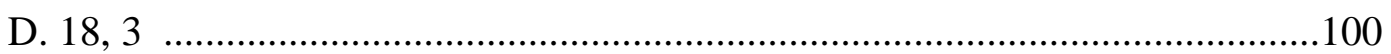

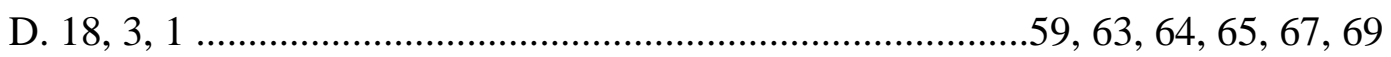

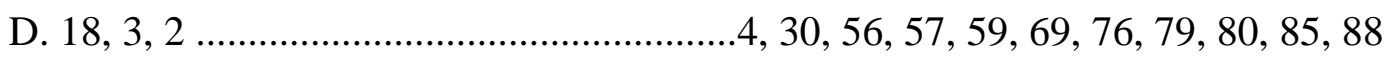

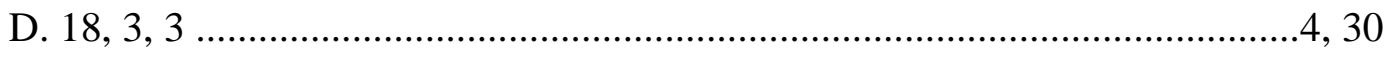


D. $18,3,4$ pr. $. .57,59,79,82,88$

D. $18,3,4,1$ .59

D. $18,3,4,2$ .99

D. $18,3,4,3$ 59,99

D. $18,3,4,4$ .99

D. $18,3,5$ $.7,57,62,63,70,75,76$

D. $18,3,6$ pr. .57

D. $18,3,6,1$ .59

D. $18,3,8$. .73

D. $18,5,10 \mathrm{pr}$ .57

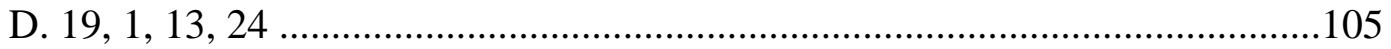

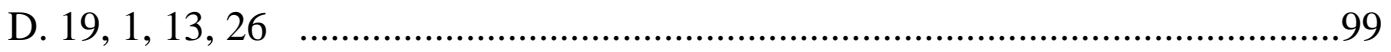

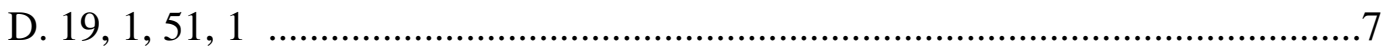

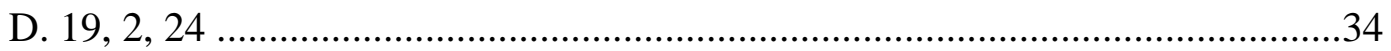

D. $20,1,3$ pr. .............................................................................. 101,102

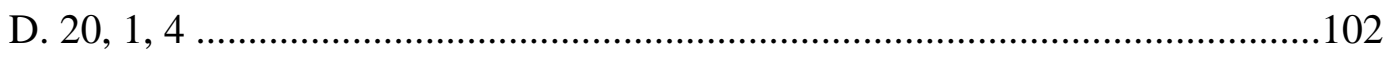

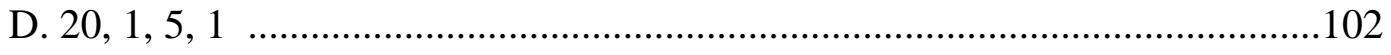

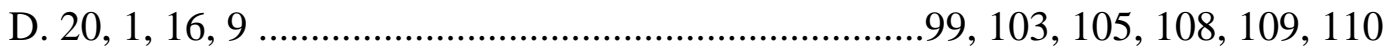

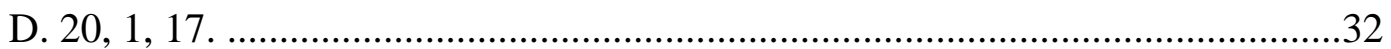

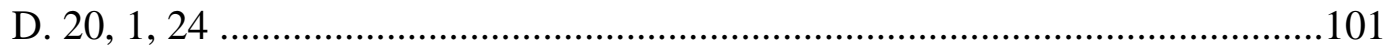

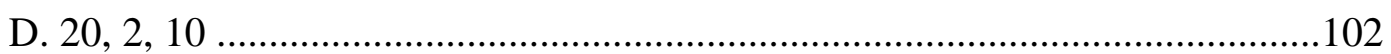

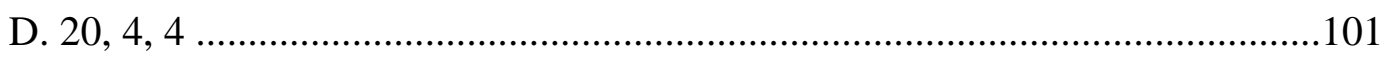

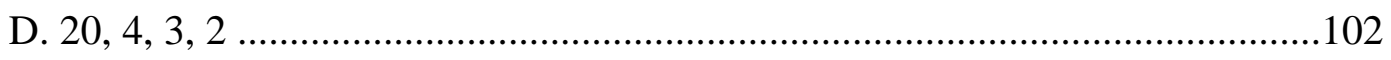

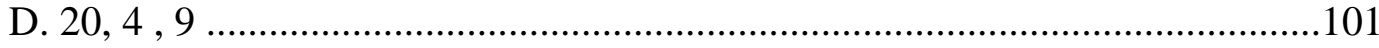

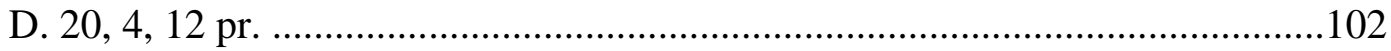

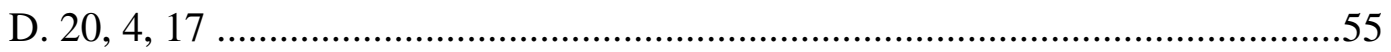

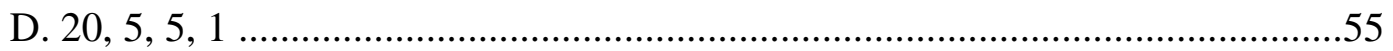

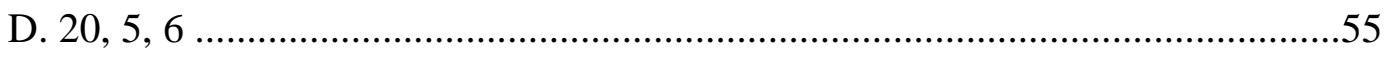

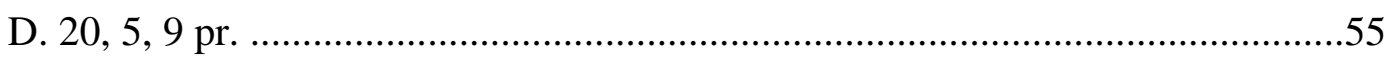

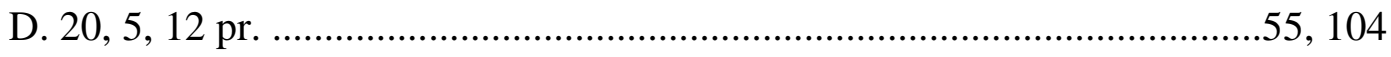

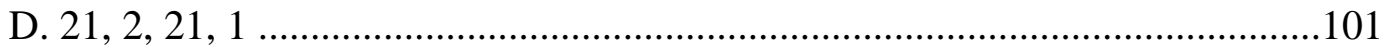




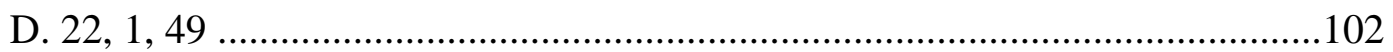

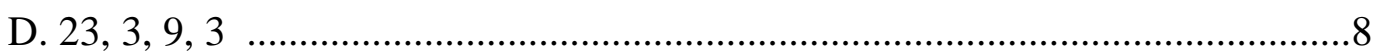

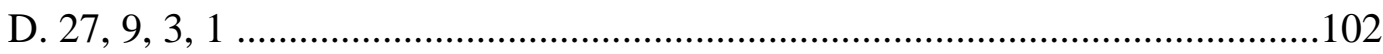

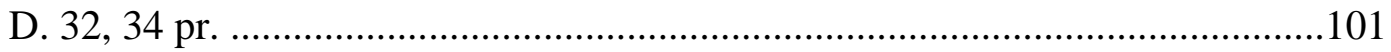

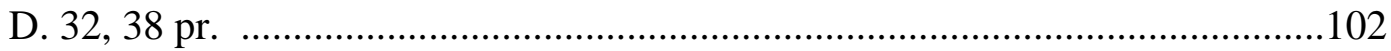

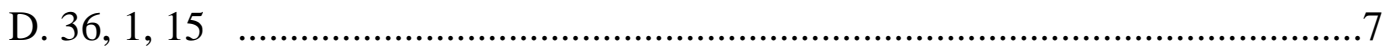

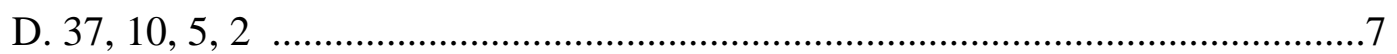

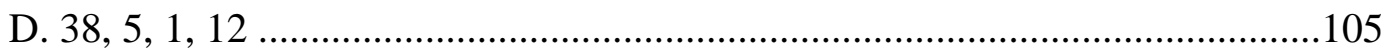

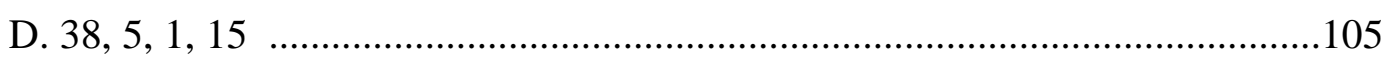

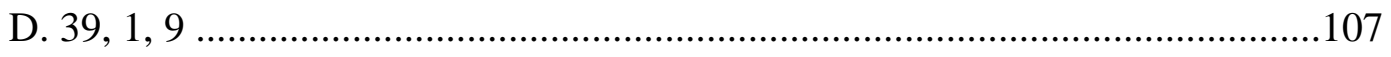

D. $39,5,18,2$

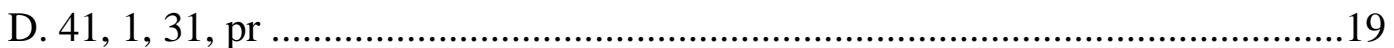

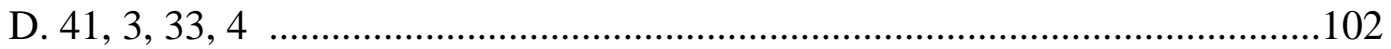

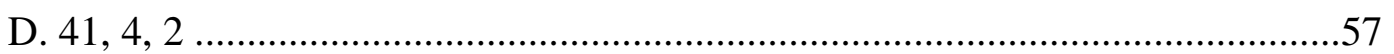

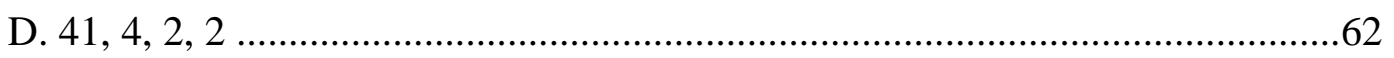

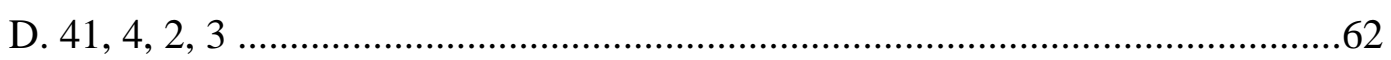

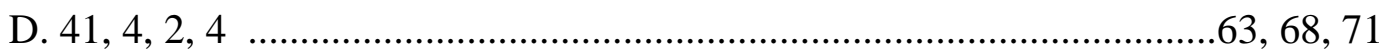

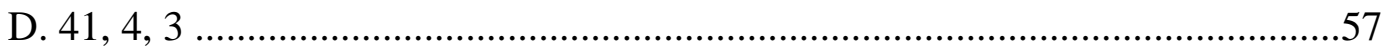

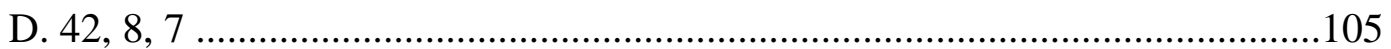

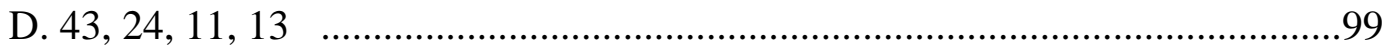

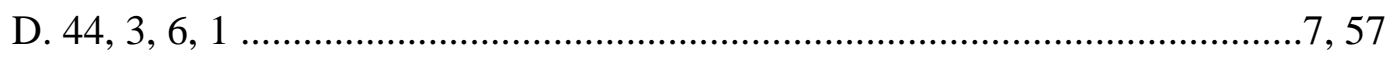

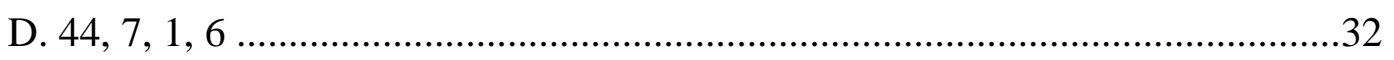

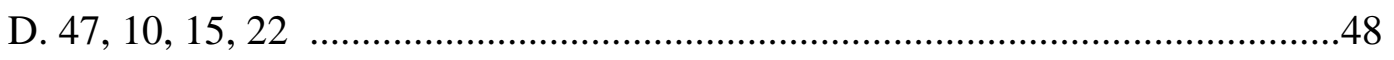

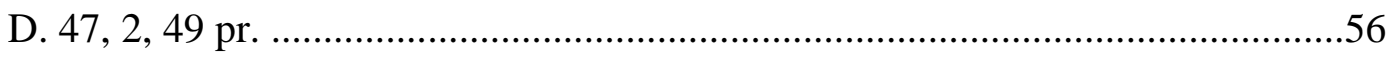

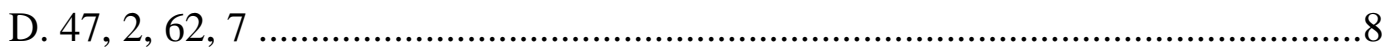

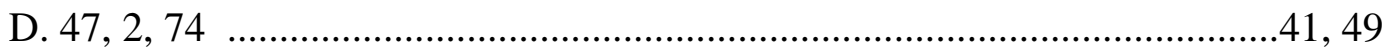

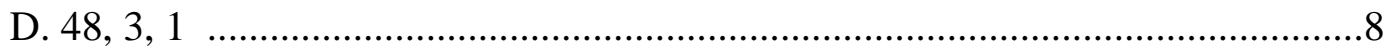

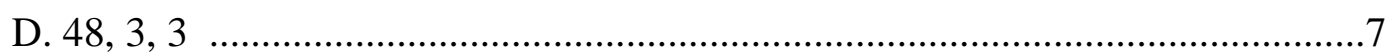

D. $48,3,14$ pr.

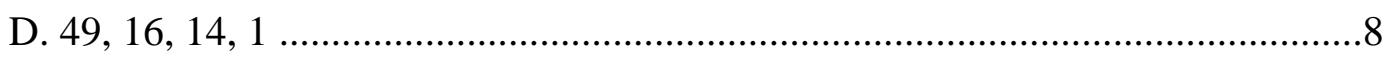

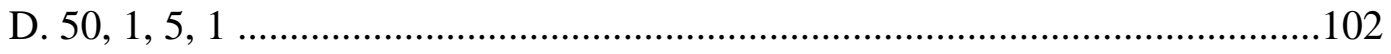


D. $50,9,1$

D. $50,17,72$

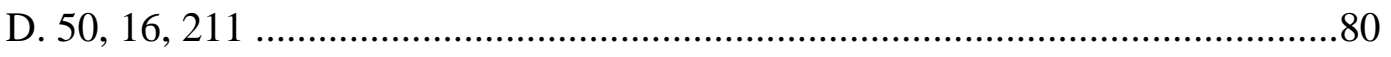

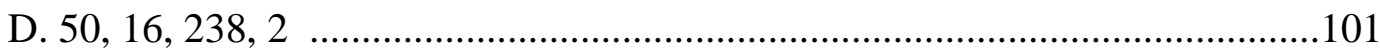

\section{Codex}

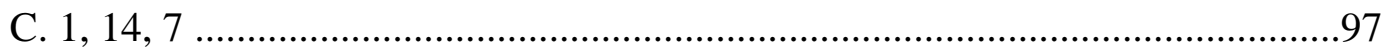

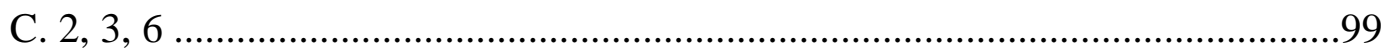

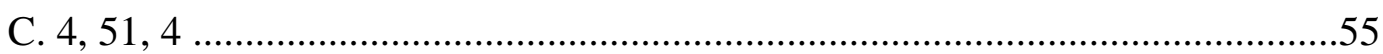

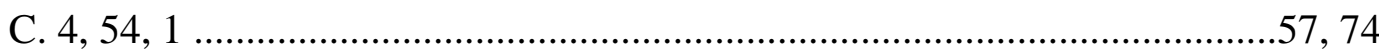

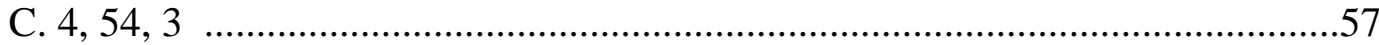

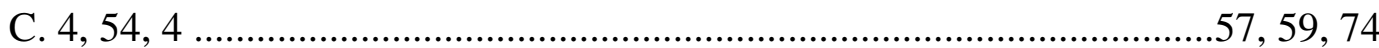

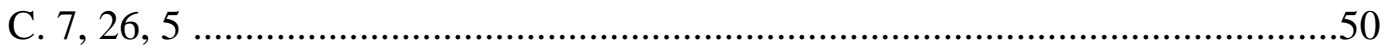

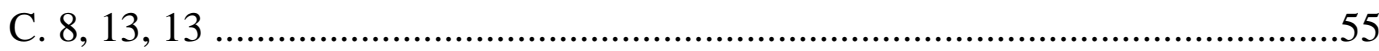

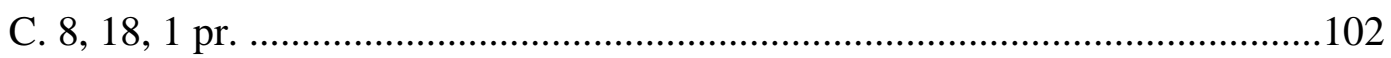

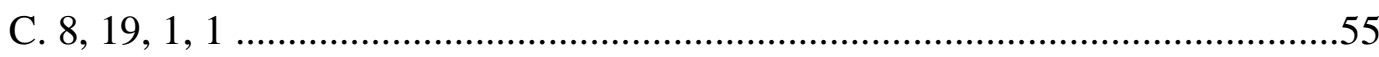

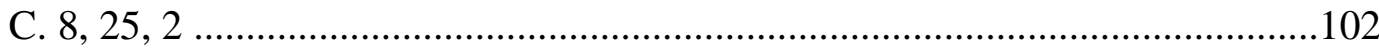

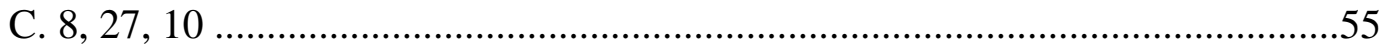

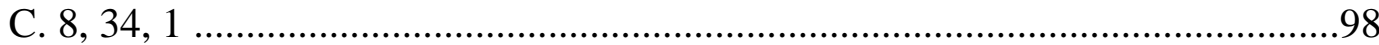

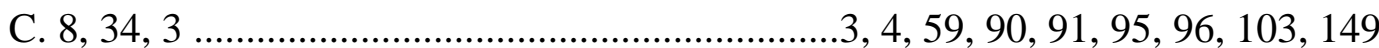

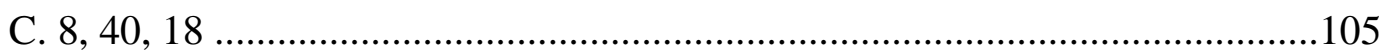

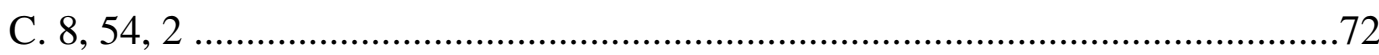

\section{Novellae}

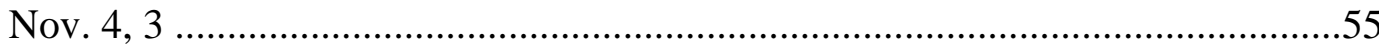

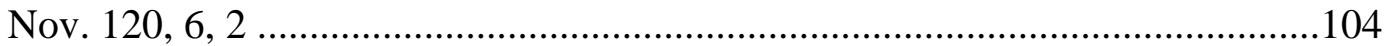

\section{Bizantinas}

Bas. 19, 3, 1 


\section{Inscrições e Papiros}

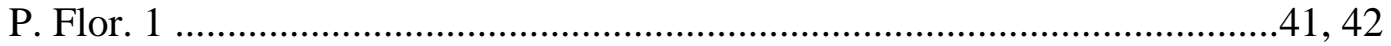

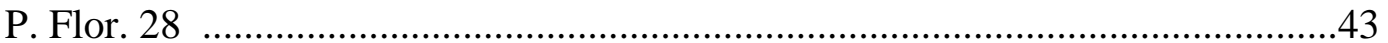

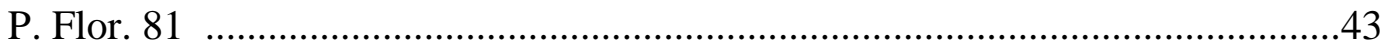

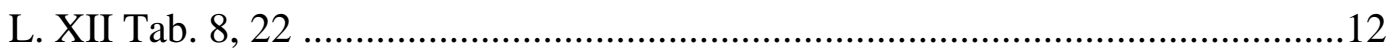

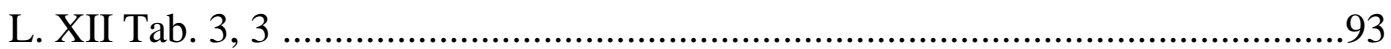

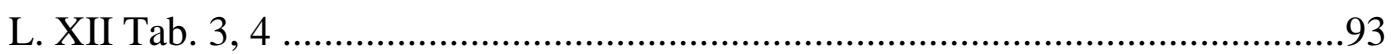

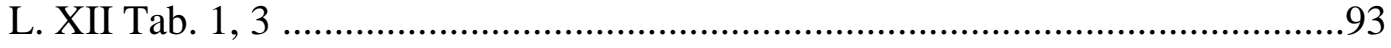

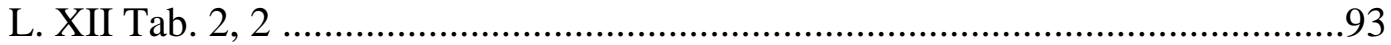

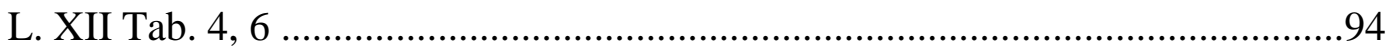

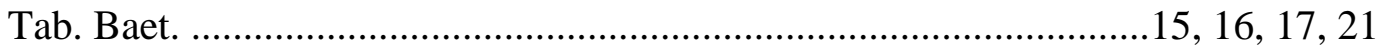

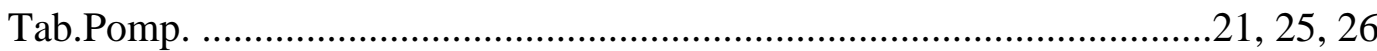

\section{FonTES Não JuRÍdicAS ANTIGAS}

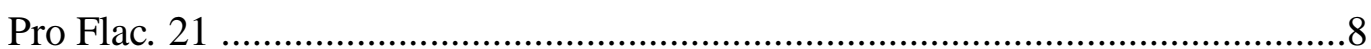

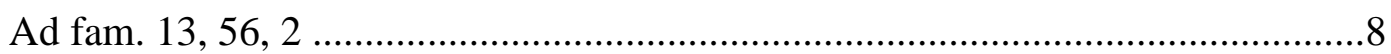

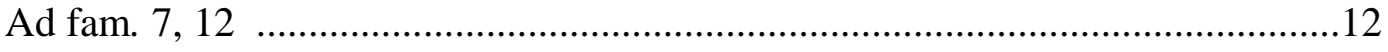

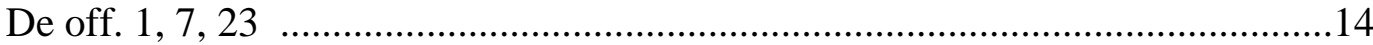

De off. $3,15,61$

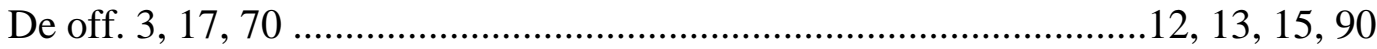

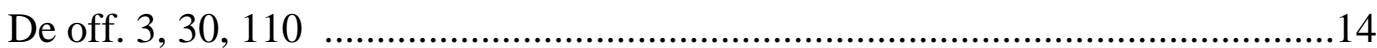

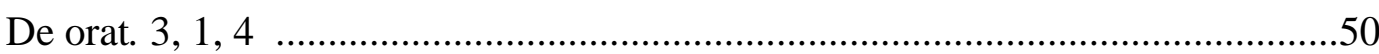

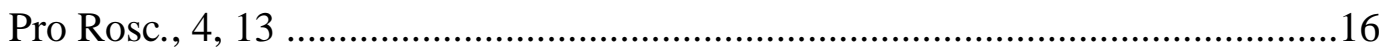

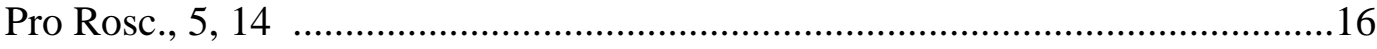

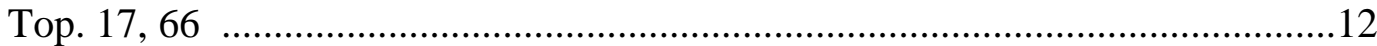

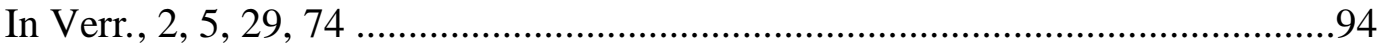

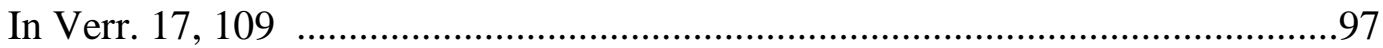

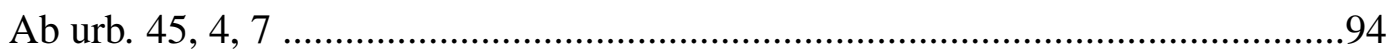




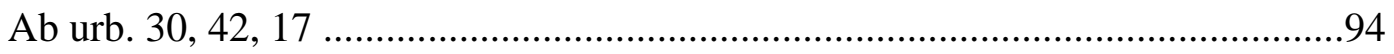

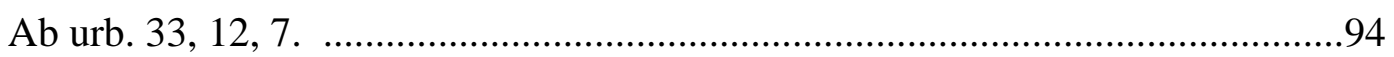

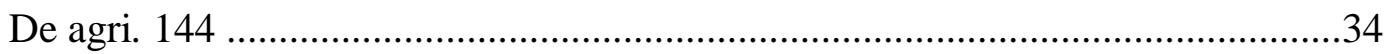

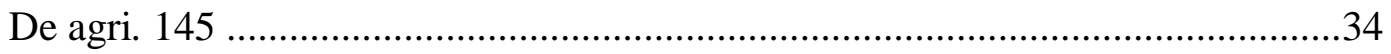

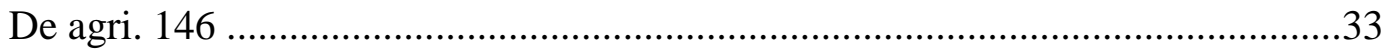

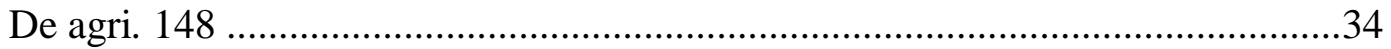

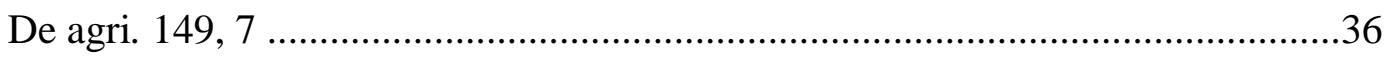

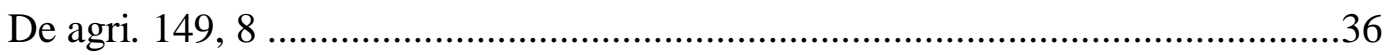

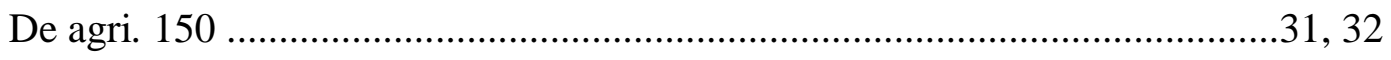

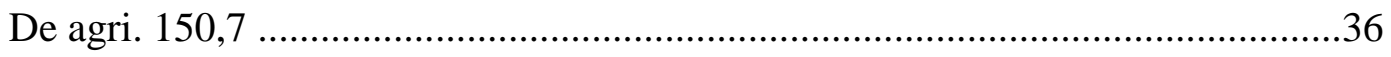

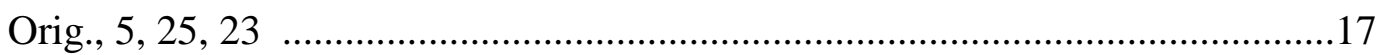

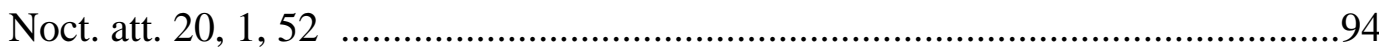

\section{FONTES JURÍDICAS INTERMÉDIAS}

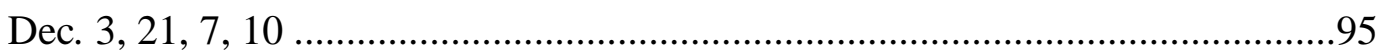

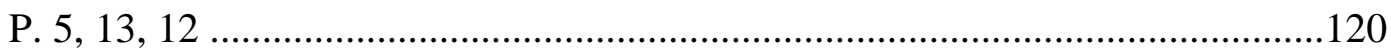

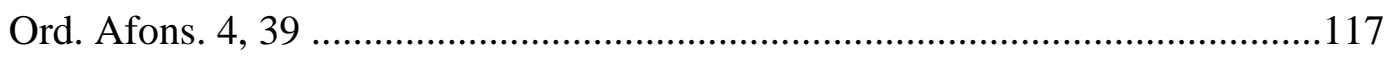

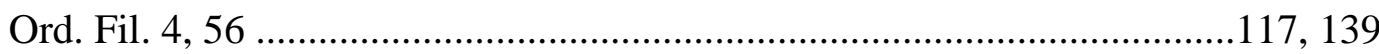

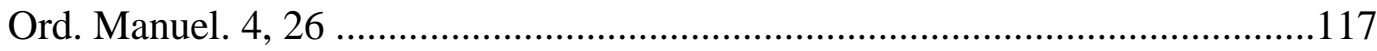




\section{RESUMO}

Ao longo de seu texto, o Código Civil de 2002 não traz o vocábulo "comissório" ou quaisquer de suas possíveis flexões gramaticais. Na doutrina e jurisprudência pátrias, entretanto, ele é aplicado exaustivamente quanto à proibição prevista nos artigos 1.428 e 1.365 do mencionado diploma legal.

Grosso modo, tem-se em tais dispositivos a impossibilidade de que, após verificado o inadimplemento da obrigação principal, possa o credor insatisfeito conservar para si, na condição de proprietário, a coisa entregue em garantia.

Ainda que reproduzida em diversos códigos modernos, especialmente naqueles de tradição romano-germânica, essa vedação ao chamado pacto comissório é um tema pouquíssimo estudado. A necessidade de uma maior reflexão sobre seu conteúdo, no entanto, é cada vez mais evidente. Isso porque, como demonstram pesquisas recentes no âmbito da literatura comparística, há indícios de que a regra tem por base fundamentos que não mais se justificariam.

A esse propósito, vale salientar, o estudo do direito romano é fundamental. Afinal, nele a lex commissoria foi criada e por séculos teve aplicação no âmbito dos direitos reais de garantia, até ter sido proibida pelo Imperador Constantino (C. Th. 3, 2, 1; C. 8, 34, 3), no século III.

O presente trabalho, portanto, tem por objetivo central a reconstrução e análise do instituto antigo, para que então com mais segurança seja possível delimitar, em que medida, pôde a lex commissoria romana influenciar a proibição do pacto comissório nos atuais ordenamentos jurídicos, em especial, o brasileiro.

Para tanto, deve-se notar, em um primeiro momento, que separar a lex commissoria objeto da mencionada decisão da mais consagrada lex commissoria no âmbito da compra e venda, recepcionada no livro 18 do Digesto e ainda largamente aceita nos sistemas modernos, não é tarefa das mais fáceis. Tendo a proibição sido anterior à compilação do Corpus Iuris e, igualmente, tendo a própria fiducia cum creditore sido extinta por volta do século II, escassos são os testemunhos nas fontes que chegaram até os nossos dias. 


\begin{abstract}
Throughout its text, Brazilian Civil Code of 2002 does not have the word "comissório" or any of its possible grammatical inflections. In Brazilian doctrine and jurisprudence, however, it is applied thoroughly as the prohibition laid down in Articles 1,428 and 1,365 of that statute.

Roughly speaking, we have in such provisions the impossibility that, upon inspection of the default of the principal obligation, unsatisfied creditors could keep for themselves the thing given as a real security (pledge), provided being the owner.

Although reproduced in many modern codes, especially those of Roman-Germanic tradition, the prohibition of the so called "pacto comissório" is a topic rarely researched. The need for further reflection on its contents, however, is increasingly evident. This is because, as recent research into comparative literature shows, there is evidence that this rule is based on essentials that would no longer be justified.

In that regard, it is worth mentioning, the study of Roman law is fundamental. After all, in it the lex commissoria was created and for centuries it had been applied under the provision of security until it was banned by Emperor Constantine (C. Th. $3,2,1$; C. $8,34,3)$ in the $3^{\text {rd }}$ century A.D.

The present study, therefore, has as its central objective the reconstruction and the analysis of that ancient institute, so that more safely it will be possible to delimit to what extent could the Roman lex commissoria influence the "pacto comissório" in current legal systems, in particular the Brazilian one.

Therefore, it should be noted at first that to separate the lex commissoria, object of the aforementioned ban, from the established lex commissoria under purchase and sale, as disposed in Book 18 of the Digesta and still widely accepted in modern systems, it is not an easy task. Since the prohibition was prior to the compiling of the Corpus Iuris and also having the fiducia cum creditore been extinct sometime around the $2^{\text {nd }}$ Century, testimonies in sources that have come down to our day are scarce.
\end{abstract}




\section{BIBLIOGRAFIA}

(somente das obras consultadas)

ACUTIS, Giuseppe, De lege commissoria, Torino, Subalpina, 1901.

ADICKES, Franz, Zur Lehre von den Bedingungen nach römishen und heutigem Recht (eine Vorarbeit für das deutsche Civilgesetzbuch), Berlin, Guttentag, 1876.

ADELLE, Jean-François, La réforme des sûretés mobilières corporelles et les opèrations de financemente - ambitions et limites, in Option Finance 893-894 (2007).

Albaladejo, Manuel, Derecho Civil-Derechos de Bienes, v. 2, Madri, Bosch, 1994.

Albanese, Bernardo, Gli atti negoziali nel diritto privato romano, Palermo, Università di Palermo, 1982.

Albertario, Emilio, Alcune osservazioni sulla legislazione di Costantino, in Actis Congressus Iuridici Internationalis, v. 1, Roma, 1934.

Contratti agrari nel 'de agri cultura' di Catone, in Rivista di diritto agrario 15 (1936).

La terminologia del possesso nella compilazione giustinianea e nelle fonti bizantine, in BIDR 27 (1914).

Sulla nullità del patto commissorio aggiunto al mutuo ipotecario, in Rivista del diritto comerciale e del diritto generale delle obligazioni, XXII, n. 5, Milano, Francesco Vallardi, 1924.

Vecchi e nuovi problemi intorno alla terminologia del possesso, in Studii Chironi I, Torino.

Allara, Mario, Le nozioni fondamentali del diritto civile, $5^{\mathrm{a}}$ ed., Torino, Giappichelli, 1958.

Almeida Costa, Mario Julio de, Alienação fiduciária em garantia e aquisição de casa própria - Notas de direito comparado, in Direito e Justiça, v. 1, n. 1, 1980.

História do direito português, $3^{\mathrm{a}}$ ed., Coimbra, Almedina, 1996. 
Antecipada, in Colectânea de Jurisprudência, t. 2, v. 10, 1985.

Almeida costa, Mário Julio de, História do direito português, $3^{\mathrm{a}}$ ed., Coimbra, Almedina, 1996.

Alves, João Luiz, Código civil da República dos Estados Unidos do Brasil annotado, Rio de Janeiro, Briguet, 1923.

Amaral, Francisco, Direito civil - Introdução, $4^{\mathrm{a}}$ ed., Rio de Janeiro, Renovar, 2002.

Amaral Neto, Francisco dos Santos, A alienação fiduciária em garantia no direito brasileiro, in Contratos em espécie: atribuição patrimonial e garantia, TEPEdino, Gustavo, FACHIN, Luis Eduardo (org.), São Paulo, RT, 2011.

Da irretroatividade da condição suspensiva no direito civil brasileiro, Rio de Janeiro, Forense, 1984.

Ambrosino, Rodolfo, La legis actio sacramento in personam e la protezione giuridica dei rapporti fiduciari, in Studi in onore di Vincenzo Arangio-Ruiz, II, v. 2, $1^{\text {a }}$ ed., Napoli, Giuffrè, 1952.

AnKun, Hans, Alla ricerca della 'repromissio' e della 'satisdatio secundum mancipium', in Atti del IV Congresso Internazionale dell'Accademia Romanistica Constantiniana, Perugia, 1981.

Andrade de Matos, Isabel, O Pacto Comissório, Coimbra, Almedina, 2006.

Andrioli, V., Commentario del Codice Civil - Tuttela dei diritti. Art. 2.7402.899, v. 6, Scialoja, Antonio, BrancA, Giuseppe (org.), Bologna, Nicola Zanichelli, 1945.

Disciplina intertemporale del patto commissorio e sua applicabilità ai privilegi speciali, in Foro Italiano, v. 67, Torino, Giappichelli, 1942.

ANELLI, Franco, L'alienazione in funzione di garanzia, Milano, Giuffrè, 1996.

, Problemi dell'alienazione in funzione di garanzia - Trasferimento dei diritti e divieto del patto commissorio, Pavia, Zanichelli, 1992.

ANGELONI, Franco, Sulla responsabilità disciplinare del notaio che roghi un atto contenente un presunto patto commissorio, in Contratto e Impresa, v. 16, n. 3, Padova, 2000. 
Antunes Varella, João de Matos, Das obrigações em geral, v. 2, $10^{\text {a }}$ ed., Lisboa, Almedina, 2000.

Arangio-Ruiz, Vicenzo, Istituzioni di diritto romano, $14^{\mathrm{a}}$ ed., Napoli, Jovene, 1960.

La compravendita in diritto romano, $2^{\mathrm{a}}$ ed., v. 1 e 2, Napoli, Jovene, 1954.

, Responsabilità contratuale in diritto romano, $2^{\mathrm{a}}$ ed., Napoli, Jovene,

1958. ArCangeli, Ageo, I contratti agrari nel 'De agri cultura' di Catone, in Studi Pier Paolo Zanzucchi, Milano, 1927.

ARCHI, Gian Gualberto, Condizione nel negozio giuridico (diritto romano), in ED 8 (1961).

, Il negozio sotto condizione sospensiva nella compilazione di Giustiniano, in Studi in onore di Emilio Betti II, Milano, Giuffrè, 1962. , Il trasferimento della proprietà nella compravendita romana, Padova, CEDAM, 1934.

Indirizzi e problemi del sistema contrattuale nella legislazione da Costantino a Giustiniano, in Studi in Onore di Contardo Ferrini, Milano, Hoepli, 1946.

La restituzione dei frutti nelle vendite con "in diem addictio" e con "lex commissoria", in Studi in memoria di Umberto Ratti, Milano, Giuffrè, 1934. Arndts von ARneSBERG, Ludwig, Lehrbuch der Pandekten, 1887, trad. It. De F. Serafini, Trattato delle Pandette II, $3^{\mathrm{a}}$ ed., Bologna, Fava e Garagnani, 1880.

AsCOLI, Alfredo, Le origini dell'ipoteca e l'interdetto salviano, Livorno, Raff. Giusti, 1887.

ASTUTI, Guido, Dazione in pagamento - Diritto romano e intermedio, in ED 9 (1962).

Avena-Robardet, Valérie, La réforme du droit des sûretés, in Recueil Dalloz 19 (2006).

Avonzo, Franca de Marini, Diritto romano e diritto privato - Letture da F.K. Von Savigny, 1ª ed., Torino, G. Giappichelli, 1995. 
Aynès, Laurent, CrocQ, PIERRE, Les sûretés - La publicite foncière, $5^{\mathrm{a}}$ ed., Paris, Cujas, 1993.

AzEvedo, Álvaro Villaça, Código civil comentado II (negócio jurídico; atos jurídicos lícitos; atos ilícitos), São Paulo, Atlas, 2003.

BaChofen, Johann Jacob, Das römische Pfandrecht, Basel, Schweighausersche, 1847.

BARASSI, Lodovico, Istituzioni di diritto civile, $2^{\mathrm{a}}$ ed., Milano, Giuffrè, 1945.

BARBIERA, Lelio, Garanzia del credito e autonomia privata, Napoli, Jovene, 1971.

Responsabilità patrimoniale - Disposizioni genelali, in Il Codice Civile - Commentario diretto da Piero Schlesinger. Art. 2740-2744, Milano, Giuffrè, 1991.

BAREA, Juan Bautista Jordano, El Negócio Fiduciario, Madrid, J. M. Bosch, 1959.

BAUDY, Dorothea, Römische Ungangsriten - Eine ethologische Untersuchung der Funktion Von Wiederholung für religiöses Verhalten, Berlin - New York, W. de Gruyter, 1998.

BECHMAn, August, Der Kauf nach gemeinem Recht I (Geschichte des Kaufs im römischen Recht), Erlangen, Deichert, 1876 a 1908.

Behrends, Otto, Knütel, Rolf, Kupisch, Berthold, Seiler, Hans Hermann, Corpus Iuris Civilis (Text und Übersetzung) II (Digesten 1-10), Heidelberg, Müller, 1995.

BEKKER, Ernst Immanuel, Ueber die 'leges locationis' bei Cato 'de re rustica', in SZ 3 (1864).

BELLOCCI, Nicla, La struttura del negozio della fiducia nell'epoca repubblicana - Le nuncupationes, $1^{\text {a }}$ ed., v. 1, Napoli, Eugenio Jovene, 1979.

, La tutela della fiducia dalle origini alla fine della repubblica, Siena, Universitá di Siena, 1971.

BENEDEK, Ferenc, Die iusta causa tradiionis im römischen Recht, 1962, in Acta Juridica Academiae Scientiarum Hungaricae, t. 4, fasc. 1-2, Budapest, Akademai Kiado, 1991. 
BENVENISTE, Émile, Le vocabulaire des institutions indo-européenes II Pouvoir, droit, religion, Paris, Minuit, 1969.

BERGER, Adolf, Encyclopedic dictionary of roman law, Philadelphia, The American Philosophical Society, 1953.

Bernardes De Mello, Marcos, Teoria do fato jurídico - Plano da eficácia, São Paulo, Saraiva, 2003.

, Teoria do fato jurídico - Plano da validade, $2^{\mathrm{a}}$ ed., São Paulo, Saraiva, 1997.

BESELER, Gerhard, Beiträge zur Kritik der römischen Rechtsquellen I, Tübingen, Mohr, 1910.

BETTI, Emilio, La vindicatio romana primitiva e il suo svolgimento storico nel diritto privatto e nel processo, in Il Filangieri, v. 39, Napoli, Eugenio Jovene, 1915.

, La retroattività della "condicio" ("facti" o “iuris") in diritto giustinianeo, in Scritti di diritto romano in onore di Contardo Ferrini, Milano, Hoepli, 1946, pp. 477 e ss.

, "Periculum" - Problemi del rischio contrattuale in diritto romano classsico e giustinianeo, in Studi in onore di P. De Francisci, v. 1, Milano, 1956.

, Su gli oneri e i limiti dell'autonomia privata in tema di garanzia e modificazione di obbligazioni, in Rivista del Diritto Commerciale e del Diritto Generale delle Obbligazioni, v. 24, Milano, Francesco Vallardi, 1931.

Sul carattere causale della 'traditio' classica - A proposito di studi recenti, in Studi Riccobono, v. 4, Palermo, 1936.

Sul valore dogmatico della categoria 'contrahere'in giuristi proculiani e sabiniani, in BIDR. 28 (1915).

Teoria generale delle obbligazioni,v. 1, Milano, Giuffrè, 1955.

Bevilacqua, Clóvis, Código Civil dos Estados Unidos do Brasil III, $2^{\mathrm{a}}$ ed., Rio de Janeiro, Francisco Alves, 1921.

Bianca, Cesare Massimo, Diritto civile III (il contratto), $2^{\mathrm{a}}$ ed., Milano, Giuffrè, 2000 .

Il divieto del patto commissorio, Milano, Giuffrè, 1957. 
, Patto commissorio (voce), in Novissimo Digesto Italiano, v. XII, Torino, UTET, 1965.

Realtà sociale ed effettività della norma, Milano, Giuffrè, 2002.

BiAnChinI, Mariagrazia, La disciplina degli interessi convenzionali nella legislazione giustinianea, in Studi in onore di A. Biscardi II, Milano, 1982.

BIONDI, Biondo, Contratto e stipulatio (corso di lezioni), Milano, Giuffrè, 1953.

, "Humanitas" nelle leggi degli imperatori romano-cristiani, in Fontes Ambrosiani, v. 26, Firenze, L.S. Olschki, 1951.

Il diritto romano cristiano - La Famiglia - Rapporti patrimoniali Diritto pubblico. v. 3. $1^{\text {a }}$ ed. Milano: Giuffrè, 1952.

, Il diritto romano cristiano - Orientamento religioso della legislazione,

v. 1, Milano, Giuffrè, 1952.

Istituizioni di diritto romano, Milano, Giuffrè, 1946.

, "Iudicia bonae fidei", in Annali del Seminario giuridico della

Università di Palermo, 7 (1920).

Lex e ius, in BIDR 47 (1964).

BISCARDI, Arnaldo, Appunti sulle garanzie reali in diritto romano, Milano, Cisalpino-Gollardica, 1976.

, La "lex commissoria" nel sistema delle garanzie reali, in Studi in Onore di Emilio Betti, v. 2, Milano, Giuffrè, 1962.

, Le garanzie reali del credito, Siena, Giubbi \& C., 1957.

Bonfante, Pietro, Corso di diritto romano, Roma, Sampaolesi, 1932.

, Diritto delle obligazioni, 10 a ed., Torino, G. Giappichelli, 1946.

, Essenza della "bona fides" e suo raporto colla teoria dell'errore, in

Scritti Giuridici Varii, v. 2, Torino, Unione Tipografico, 1916.

Istituzioni di diritto romano, $10^{\mathrm{a}}$ ed., Torino, G. Giappichelli, 1946.

, Sulla genesi e l'evoluzione del 'contractus`, in RIL. 40 (1907), Torino,

1921.

Bongiorno, Girolamo, L'autotutela esecutiva, Milano, Giuffrè, 1984.

BORDA, Guillermo, Tratado de Derecho Civil - Reales, v. 2, Buenos Aires, Perrot, 1975. 
BOVE, Lucio, Documenti di operazioni finanziarie dall'archivio dei Sulpici Tabulae Pompeianae di Murécine, Napoli, Liguori, 1984.

Brasiello, Ugo, Sull'influenza del cristianesimo in matéria di elemento subbiettivo Nei contratti, in Scritti di diritto romano in onore di Contardo Ferrini, Milano, Hoepli, 1946.

BREAUChet, Ludovic, Histoire du droit prive de la republique athénienne, v. 3, Paris, Marescq Ainé, 1855.

Breglia, Oreste, Patto commissorio, Roma, Athenaeum, 1939.

Broggini, Gerardo, Ius lexque esto, in Coniectanea - Studi di Diritto Romano, Milano, Giuffrè, 1966. , La retroatività della lege nella prospectiva Romanistica, in Coniectanea (Studi di Diritto Romano), Milano, 1966.

BRUgI, Biagio, Il patto commissorio ex intervallo, in Rivista del Diritto Commerciale e del Diritto Generale delle Obbligazioni, v. 24, Milano, Francesco Vallardi, 1919.

Brugi, M. Iacuniello, Patto commissorio (voce), in Enciclopedia Giuridica, Roma, Istituto della Enciclopedia Italiana, 2010..

BrutTI, Massimo, Il diritto privato nell'antica Roma, $2^{\mathrm{a}}$ ed., Torino, G. Giappichelli, 2011.

BUCKLAND, William Warwick, A Text-Book of Roman Law - From Augustus to Justinian, Cambridge, 2007.

Ritual Acts and Words in Roman Law, in Festschrift Koschaker I, Weimar, 1939.

BUCKLER, William Hepburn, The Origin and History of Contract in Roman Law down to the end of the Republican Period, London, C. J. Clay \& Sons, 1895.

Bulhões Pedreira, José Luiz, Finanças e demonstrações financeira das companhias - conceitos fundamentais, $2^{\mathrm{a}}$ ed., Rio de Janeiro, Forense, 1989.

BURDESE, Alberto, Catone e la vendita di vino, in SDHI 46 (2000).

La menzione degli eredi nella fiducia cum creditore, in Studi Solazzi, Napoli, 1948. 
Lex commissoria e ius vendendi nella fiducia e nel pignus, Torino, G.

Giappichelli, 1949.

, Manuale di diritto privato romano, $4^{\mathrm{a}}$ ed., Torino, UTET, 1993. , Pegno (diritto romano), in ED 32 (1982).

BUSSANI, Mauro, Il problema del patto commissorio - Studio di diritto comparato I, Torino, Giappichelli, 1999.

Patto commissorio, proprietà e mercato, in Rivista critica del diritto privato, Napoli, Jovene, 1997.

BuZAID, Alfredo, Do concurso de credores no processo de execução, São Paulo, Saraiva, 1952.

Calboli, G., Cicerone, Catone e i neoatticisti, in Ciceroniana, Leiden, E. J. Brill, 1975.

Calonge, Alfredo, En torno al problema de la retroactividad de la condición em el derecho clásico, in Studi in onore di Edoardo Volterra III, Milano, Giuffrè, 1971.

CaPuto, Emilio, Vendita a scopo di garanzia e patto commissorio, in Giustizia Civile, Milano, Giuffrè, 1979.

Cannata, Carlo Augusto, Atto giuridico e rapporto giuridico, in SDHI 57 (1991).

, Profilo istituzionale del processo privato romano II (Il processo formulare), Torino, Giappichelli, 1982.

Carassai, C., La politica religiosa di Costantino il Grande, Roma, Società Romana di Storia Patria, 1901.

Cardillu, Riccardo, La nozione giuridica di "fructus", Napoli, Edizioni Scientifiche Italiane, 2000.

CARIOTA-FERrara, Luigi, Negozi Fiduciari,Padova, CEDAM, 1933.

CARnelutti, Francesco, Mutuo pignoratizio e vendita con clausola di riscatto, in Rivista di Dirito Processuale, Milano, F. Vallardi, 1946. . Note sul patto commissorio, in Studi di diritto processuale, v. I, Padova, Cedam, 1928. 
Carvalho Fernandes, Luís, A admissibilidade do negócio fiduciário no direito português, in Estudos sobre a Simulação, Lisboa, Quid Iuris?, 2004.

, Lições de Direitos Reais, $4^{\mathrm{a}}$ ed., Lisboa, Quid Iuris?, 2003. , A conversão dos negócios jurídicos civis, Lisboa, Quid Iuris?, 1993. , Teoria Geral do Direito Civil, v. 2, $3^{\mathrm{a}}$ ed., Lisboa, Universidade Católica, 2001.

Carvalho Santos, João Manoel de, Código civil brasileiro interpretado Direito das coisas (arts. 755-862), v. 10, 9a ed., Rio de Janeiro, Freitas Bastos, 1964.

Carvalhosa, Modesto, Comentários à lei de sociedades anônimas, v. 2, 4a ed., São Paulo, Saraiva, 2008.

Casati, Ettore, Russo, Giacomo, Manuale dei diritto civile italiano, Torino, UTET, 1950.

Catalano, Pierangelo, Aspetti spaziali del sistema giuridico-religioso romano, in Aufstieg und Niedergang der römischen Welt II - 16.1, Berlin - New York, W. de Gruyter, 1978.

, Contributi allo Studio del diritto augurale, Torino, G. Giappichelli, 1960.

Cerami, Pietro, Risoluzione del contratto (diritto romano), in Enc. Dir. 40, Milano, 1989.

Cervenca, Giuliano, Usura (diritto romano), in ED 45, Milano, 1992.

ChADEL, Louis, Étude sur le "jus distrahendi" dans la fiducie le gage et l'hypothèque, Paris, Nouvelle, 1902.

Chalhub, Melhim Namen, Negócio fiduciário, alienação fiduciária, cessão fiduciária e securitização, $3^{\mathrm{a}}$ ed., Rio de Janeiro, Renovar, 2006.

Champeaux, Ernest, Le príncipe de simplicité des anciens actes juridiques romains et le gage, in Mélanges $P$. F. Girard: études de droit romain dédiées a $P$. F. Girard à l'occasion du 60 anniversaire de as naissance (26 octobre 1912), v.1, Paris, 1912.

Chemin-Bomben, Délphine, Ordonnance "sûretés" - fiche de lecture du nouveau libre IV du Code Civil, in Revue Lamy Droit des Affaires 5 (2006). 
Chinè, Giuseppe, Lascialfari, Massimo, Magni, Francesco, Le garanzie rafforzate del credito, Torino, UTET, 2000.

Chironi, Giampietro, Elementi di diritto civile, Torino, Fratelli Bocca, s.d. Trattato dei privilegi, delle ipoteche e del pegno, $2^{\mathrm{a}} \mathrm{ed} ., \mathrm{Milano}, 1918$.

Cian, Giorgio, Trabucchi, Alberto (org.), Commentario breve al codice civile, 6 ${ }^{\mathrm{a}}$ ed., Padova, CEDAM, 2002.

CiPriani, Nicola, Patto commissorio e patto marciano - Proporzionalità e legittimità delle garanzie, Sannio Benevento, Facoltà di Economia dell'Università degli Studi del Sannio Benevento, 2000.

ClaPs, Tommaso, Del cosiddetto pegno irregolare, Bologna, Fava e Garagnani, 1896.

Clark, M. E. C., Jus and lex, in Mélanges Fitting, t. 1, Montpellier, Société anonyme de l'imprimerie générale du midi, 1907.

Coelho da Rocha, Manoel Antônio da, Instituições de direito civil portuguez, para uso de seus discípulos. t. 2, 2a ed., Coimbra, Imprensa da Universidade, 1848.

Collinet, Paul, Deux textes retrovés sour la fiducia, "Studi Besta, I, Milano", 1939.

Comparetti, Domenico, Vitelli, Girolami, Papiri Greco-Egizii - Papiri Fiorentini - Documenti pubblici e privati dell'età romana e bizantina, v. 1, Milano, Hoepli, 1906.

CoOper, Corrine, Weise, Steven, SMith, Edwin, The New Article 9 - Uniform Commercial Code, $2^{\mathrm{a}}$ ed., Chicago, American Bar Association, 2000.

Corradini (cur.), Francesco, Totius latinitatis lexicon, Padova, Seminario, 1864. Correa, Alexandre Augusto de Castro, Direito Romano - A Mancipatio, o Nexum e a In Iure Cessio, Tese (Professor Catedrático) - Faculdade de Direito da USP, São Paulo, 1960.

O estoicismo no direito romano, Tese (Livre Docência), São Paulo, Faculdade de Direito da USP, 1950.

CorrêA Telles, José Homem, Digesto portuguez ou tractado dos modos de adquirir a propriedade de a gozar e administrar e de a transferir por derradeira 
vontade para servir de subsídio ao novo Código Civil, t. 3, $5^{\mathrm{a}}$ edição, Coimbra, J. Augusto Orcel, 1860.

Correia, Alexandre, Sciascia, Gaetano, Correa, Alexandre Augusto de Castro, Manual de direito romano II (institutas de Giao e de Justiniano vertidas para o português, em confronto com o texto latino), $2^{\mathrm{a}}$ Ed., São Paulo, Saraiva, 1955.

CostA, Emilio, Cicerone giuresconsulto I e II, $2^{\mathrm{a}}$ ed., Bologna, Zanichelli, 1927. Sul papiro fiorentino num. 1, BIDR 14 (1901).

Costanza, Maria, Sulle alienazioni in garanzia e il divieto del patto commissorio, in GC, 1989.

Cricenti, Giuseppe, I contratti in frode alla legge, $2^{\mathrm{a}}$ ed., Milano, Giuffrè, 2008. Cubeddu, Maria Giovanna, Patto commissorio e vendita con patto di riscatto la risposta delle sezione unite, in Rivista di Diritto Civile, v. 36, n. 5, Padova, 1990.

Cunha Gonçalves, Aderbal da, Da propriedade resolúvel (sua projeção na alienação fiduciária em garantia), São Paulo, Revista dos Tribunais, 1979.

Cunha Gonçalves, Luiz da, Comentário ao Código Civil Português, v. 5, Coimbra, Coimbra, 1932.

Tratado de Direito Civil, v. 4, tomo 2, $2^{\mathrm{a}}$ ed., São Paulo, Max Limonad, 1955.

CuQ, Edouard, Les institutions juridiques des romains 1, $2^{\text {a }}$ ed., Paris, Plon, 1904.

D’ors Pérez-Peix, Álvaro, Derecho privado romano, $8^{\mathrm{a}}$ ed., Pamplona, Universidad de Navarra, 1991. In diem addictio (contribución a la critica de la teoria de las condiciones en derecho romano), in AHDE 16 (1945). , Sobre las pretendidas acciones reales “in factum”, in IURA 20 (1969). Dalmartello, Arturo, "Fiducia cum creditore" e prescrizione, in Il Contrato Sologe in onore di Giorgio Oppo, v. 1, Padova, CEDAM, 1992.

De Martini, Angelo, Profili della vendita commerciale e del contratto estimatorio, Giuffrè, Milano, 1950. 
DE CiCco, Maria Cristina, Il divieto del patto commissorio, in L. Ferroni (a cura di), Le nullità negoziali, Milano, 1998.

De FranciscI, Pietro, Il trasferimento della proprietà - Storia e critica di una dottrina, Padova, Universitaria, 1924.

Recensioni a Salvatore Calderone, Costantino e Il Cattolicesimo, I, Firenze, 1962.

De Martino, Francesco, Individualismo e diritto romano privato, $22^{\mathrm{a}}$ ed. , Torino, Giappichelli, 1999.

De NiCTOLIS, Rosanna, Divieto del patto commissorio, alienazioni in garanzia e “sale-lease-back”, in Rivista di Diritto Civile, v. 37, n. 5, Padova, 1991. , Nuove garanzie personali e reali, Padova, CEDAM, 1998.

De RugGiero, Roberto, Il divieto di alienazione del pegno nel diritto greco e romano - Contributo papirologico, Roma, L’Erma di Bretschneider, 1910.

De Senarclens, Alexandre, La maxime "pretium debet esse verum, certum, iustum", in Mélanges Paul Fournier, Paris, Sirey.

Del Nero, João Alberto Schützer, Conversão substancial do negócio jurídico, Rio de Janeiro, Renovar, 2001.

Delvincourt, Claude-Étienne, Institutes de droit civil français, t. 2, 2a ed., Paris, P. Gueffier, 1810.

DernburG, Heinrich, Das Pfandrecht nach den Grundsätzen des heutigen römischen Rechts, v. 2, Leipzig, Hirzel, 1864.

DeVILla, Vicenzo, L’ius distrahendi nella fiducia e nel pignus, Sassari, Galizzi, 1937.

Di Marzo, Salvatore, Istituzioni di diritto romano, Milano, Giuffrè, 1945.

Dias Ferreira, José, Codigo Civil Portuguez Annotado, v. 2-3, 2a ed., Coimbra, Imprensa da Universidade, 1895.

Dinamarco, Cândido Rangel, A instrumentalidade do processo, $15^{\mathrm{a}}$ ed., São Paulo, Malheiros, 2013. Instituições de direito processual civil, São Paulo, Malheiros, 2004.

Dinız, Maria Helena, Curso de Direito Civil Brasileiro, v. 4, 24ª ed., São Paulo, Saraiva, 2009. 
DIRKSEN, Heinrich Eduard, Committere, in Manuale latinitatis fontium iuris civilis romanorum - Thesauri latinitatis epitome in usum tironum, Berolini, Dunckeri et Humblotii, 1837.

DonelLI, Hugonis, Iurisconsulti et antecessoris Opera Omnia, t. 9, Lucae, Joannis Riccomini, 1766.

DonisI, Carmine, Il problema dei negozi giuridici unilaterali, Napoli, Jovene, 1972.

DoverI, Alessandro, Istituzioni di Dirito Romano, $2^{\mathrm{a}}$ ed., v. 1, Firenze, Le monnier, 1866.

Du Cange, Charles, Committere, in Glossarium Mediae et Infimae Latinitatis, t.

II, Graz, Akademische Druck - U. Verlagsanstalt, 1954 (Unveränderter Nachdruck der Ausgabe Von 1883-1887).

DuMÉzIL, Georges, Archaic Roman Religion I, Chicago-London, University of Chicago, 1970.

DusI, Bartolomeo, Istituzioni di diritto civile, v. 2, 2 $2^{\mathrm{a}}$ ed., Torino, Giappichelli, 1937.

EBRARD, Friedrich, Die Digestenfragmente ad formulam hypothecariam, München, Veit \& Comp., 1917.

EHRHARDT, Arnold, Justa causa traditionis - Eine untersuchung über den erwerb des eigentums nach römischem recht, Berlin und Leipzig, W. De Gruyter \& Co., 1930 .

EISELE, Friedrich, Beiträge zur Erkenntniss der Digesteninterpolationem, in SZ 11 (1890).

ENnerCCERUS, Ludwig, KIPP, Theodor, Wolf, Martin, RAISER, Ludwig, Lehrbuch des Bürgerlichen Rechts III - Sachenrecht, Marburg, N. G. Elwert, 1904.

ERBE, Walter, Die Fiduzia, in SZ 61 (1941).

Die Fiducia im römischen Recht, Weimar, Hermann Böhlaus Nachf, 1940.

Ernout, Alfred, Meillet, Alfred, Dictionnaire étymologique de la langue latine - Histoire des mots, $4^{\mathrm{a}}$ ed., Paris, Klinksieck, 2001. 
ESPÍNOLA, Eduardo, Os direitos reais limitados ou direitos reais sobre coisa alheia e os direitos reais de garantia no direito brasileiro, Rio de Janeiro, Conquista, 1958.

FADDA, Carlo, Le usurae quae officio iudicis praestantus (1886-1887), in Studi e questioni di diritto I, Napoli, 1910.

FALCHI, Gian Luigi, Le controversie tra sabiniani e proculiani, Milano, Giuffrè, 1981.

FAZENda Martins, José Pedro, Direitos reais de gozo e garantia sobre valores mobiliários, in Direito dos Valores Mobiliários, Lisboa, Lex, 1997.

Feliú Rey, Manuel Ignacio, La prohibición del pacto comisorio y la opción em garantia, Madrid, Civitas, 1995.

FERRI, Giovanni Battista, Causa e tipo nella teoria del negozio giuridico, Milano, Giuffrè, 1966.

Ferrini, Contardo, Manuale di Pandette, Milano, Libreria, 1900.

Sull'origine del contratto di vendita in Roma, in Opere di Contardo Ferrini III, Milano, Hoepli, 1929.

FIKENTSCHER, Wolfgang, Schuldrecht, $9^{\text {a }}$ ed., Berlin-New York, Walter de Gruyter, 1997.

FIORI, Roberto, 'Contrahere' e 'solvere obligationem' in Q. Mucio Scevola, in Fides humanitas ius - Studii in onore di Luigi Labruna, v. 3, Napoli, 2007.

Flume, Werner, Allgemeiner Teil des Bürgerlichen Rechts 2 - Das Rechtsgeschäft - Enzyklopädie der Rechts uns Staatswissenschaft, Berlin, Heidelberg, 1975.

Fraga, Affonso, Direitos reaes de garantia - Penhor, anticrese e hipoteca, São Paulo, Saraiva, 1933.

Fragal, Michele, Del Mutuo - Arts. 1.813-1.822, in Commentario del Codice Civile IV, A. SialojA - G. BranCA (org.), $2^{\mathrm{a}}$ ed., Bologna, Zanichelli, 1966. Garanzia e diritti di garanzia, in ED 18 (1969).

Fremeaux, Eliane, DAublon, George, La réforme du droit des sûretés, in Répertoire du Notariat Defrénois 10 (2006). 
Frezza, Paolo, I formulari catoniani e le forme della protezione del creditore pignoratizio, in Studi in onore di Emilio Betti, v. 2, Milano, 1962. Le garanzie delle obbligazioni - Corso di diritto romano, v. 2, Padova, CEDAM, 1968. Preistoria e storia della "lex" pubblica, in BIDR 35 (1956).

FuentesecA, Pablo, Lineas generales de la "fiducia cum creditore", in Derecho romano de obligationes, Madrid, Centro de Estudios Ramón Araces, 1993.

Fulgencio, Tito, Direito real de hipoteca, .v. 1, $2^{\text {a }}$ ed., Rio de Janeiro, Forense, 1960.

GAFFIOT, Félix, Recupero, in Dictionnaire Latin Français, Paris, Hachette, 1934. Galgano, Francesco, Diritto privato, 6 ${ }^{\mathrm{a}}$ ed., Padova, CEDAM, 1990.

GaLlo, Filippo, In tema di origine della compra-vendita consensuale, in SDHI 30 (1964).

Galvão Telles, Inocêncio, Contratos Civis - exposição de motivos, in Revista da Faculdade de Direito da Universidade de Lisboa, v. 9, Lisboa, Faculdade de Direito de Lisboa, 1953.

GARCIA Del CORRAL, Ildelfonso L., Cuerpo de derecho civil romano I (Instituta - Digesto), Barcelona, Molinas, 1889.

García Garrido, Manuel Jesús, Diccionario de jurisprudencia romana, $3^{\mathrm{a}}$ ed., Dykinson, Madrid, 2000 (reimpr.).

García Goyena, Florencio, Concordancias, motivos y comentários del Código civil español, t. 3-4, Madrid, Civitas, 1852.

Garofalo, Luigi, La persecuzione dello stellionato in diritto romano, Padova, CEDAM, 1998.

Garrido, Roque F., Andorno, Luis O., Código Civil Anotado - Derechos Reales, v. 4, Buenos Aires, Zavalía, 1976.

GEIB, Otto, 'Actio fiduciae' und Realvertrag, in SZ 8 (1887).

GiacobBe, Emanuela, Patto commissorio, alienazioni in garanzia, vendita com patto di riscatto e frode alla legge - variazioni sul tema, in Giustizia Civile Repertorio generale annuale di legislazione, bibliografia, giurisprudenza, Milano, Giuffrè, 1997. 
GigliotTI, Fulvio, Il divieto del patto commissorio, Napoli, Edizioni Scientifiche Italiane, 1997.

, Patto commissorio autonomo e libertà dei contraenti, Napoli, 1997.

GILMORE, Grant, Security Interests in Personal Property, v. 1, 5 ed., New Jersey, The Lawbook Exchange, 2007.

GiorgianNI, Michele, L'obbligazione - parte generale delle obbligazioni, v. 1, Milano, Giuffrè, 1968.

GIRARD, Paul Frédéric, Manuel élémentaire de droit romain, Paris, A. Rousseau, 1906.

GoldSCHMIDT, Robert, Pacto comisorio, en Diccionario de Derecho privado, v. 2, Barcelona, Labor, 1961.

GOMES, Orlando, Alienação fiduciária em garantia, RT, Rio de Janeiro, 1975. Direitos reais, 19ª ed., Rio de Janeiro, Forense, 2008. Introdução ao direito civil, 12ª ed., Rio de Janeiro, Forense, 1996.

Goode, Roy, Legal Problems of Credit and Security, $5^{\mathrm{a}}$ ed., London, Sweet \& Maxwell, 2006.

Gradenwitz, Otto, Conjecturen, IV - Emptio ob nummos umd lex commissoria, in $L A B E O 33$ (1897).

Einfuhrung in Die Papyrusk, German, Nabu Press, 2010.

GraSSETTI, Cesare, Datio in solutum, in NDI 4 (1938).

GrondonA, Mauro, Funzione di garanzia, lease back e trasferimenti vietati, in Notariato, Milano, Giuffrè, 1998.

Grosso, Giuseppe, Appunti sulla formula dell'actio fiducia, in Annali dell’Università di Camerino, 3 (1929).

Contratto (diritto romano), in ED. 9 (1961).

, Contributo allo studio dell'adempimento della condizione, Torino,

Istituto giuridico della R. Università, 1930.

, Fiducia (diritto romano), in ED 17 (1968).

, Il sistema romano dei contratti, $3^{\mathrm{a}}$ ed., Torino, Giappichelli, 1963.

GuARINO, Antonio, Diritto privato romano, 11 a ed., Napoli, Jovene, 1997. 
GutiérRez Fernández, Benito, El derecho civil español - tratado de las obligaciones, t. 5, Madrid, Civitas, 1869.

HADDAD, Luis Gustavo, A proibição do pacto comissório no direito brasileiro (tese de doutorado em Direito Civil), São Paulo, FADUSP, 2013.

Função social do contrato - um ensaio sobre seus usos e sentidos (dissertação de mestrado em em Direito Civil), São Paulo, FADUSP, 2009.

HAEnel, Gustav Friedrich, Lex romana visigothorum, Lipsiae, Sumptibus et typis B. G. Teubneri, 1848.

HaYmann, Franz, Textkritische Studien zum römischen Obligationenrecht, in SZ 11 (1919).

HEBERT, Sophie, Le pacte commissoire après l'ordonnance du 23 mars 2006, in Recueil Dalloz 29 (2006).

Hedemann, Justus Wilhelm, Schuldrecht des Bürgerlichen Gesetzbuches, $3^{\mathrm{a}}$ ed., Berlin, Walter de Gruyter, 1949.

НеiмвасH, Karl Wilhelm Ernst, НеiмвасH, Gustav Ernst, Basilicorum libri LX - II (lib. XIII-XXIII continens), Lipsiae, Ambrosius Barth, 1840.

Hellerstein, Louis Arthur, Hellerstein, Stephen A., Secured transactions under article 9 - Uniform Commercial Code of Colorado, Denver, A. B. Hirschfield Press, 1967.

HENLE, Rudolf, Die rechtliche Natur der in diem addictio beim Kaufvertrage, in Festschrift Koschaker II, Weimar, Böhlau, 1939.

Herzen, Nicolas, Origine de l'hypothèque romaine, Paris, L. E. Bosch et Filius, 1899.

Heumann, Hermann Gottlieb, Seckel, Emil, Handlexikon zu swn Quellen des römischen Rechts, 10ª ed., Graz, Akademische, 1891.

Hirata, Alessandro, Dos efeitos da dação em pagamento no caso de credor evicto, in Revista da FADUSP, São Paulo, v. 96, 2002.

Hitzig, Hermann Ferdinand, Das griechische Pfandrecht, München, Arno, 1895.

Huc, Théophile, Commentaire théorique e pratique du Code Civil, v. 8, Paris, Cotillon, 1895.

HuET, Jérôme, Traité de droit civil, Paris, LGDJ, 1996. 
Hulot, Henri, Berthelot, Jean François, Les cinquantes livres du Digeste ou Pandectes de l'empereur Justinien II, Metz, Behmer et Lamort, 1804.

HusChKE, Philipp Eduard, Iurisprudentiae anteiustinianae quae supersunt - in usum maxime accademicum, $5^{\mathrm{a}}$ ed., Leipzig, Teubner, 1886.

ItUrRaSPE, Jorge Mosset, Piedeacasas, Miguel A., Tratado de Derecho Civil Derechos Reales, Santa Fé, Rubinzal-Culzoni, 2006.

JACQUelin, Rene, De la fiducie, $1^{\text {a }}$ ed., Paris, A. Giard, 1891.

JosSERAND, Louis, Cours de droit civil positif français, v. 2, 2a ed., Paris, Sirey, 1933.

JunQueira de Azevedo, Antônio, Negócio jurídico - existência, validade e eficácia, São Paulo, Saraiva, 2000.

KASER, Max, Condicio iuris und condicio tacita, in Symbolae Raphaeli Taubenschlag dedicatae, Vratislaviae, Ossolineum, 1956.

Das römische Privatrecht, v. 1, 2ª ed., München, Beck, 1971.

, Lex und ius civile, in Deutsche Landesreferate zum VII. Internationalen Kongress für Rechtsvergleichng in Uppsala, Berlin, Max-Planck Institut, 1967.

, Recensão a A. Burdese, "Lex commissoria" e "ius vendendi", in SZ 67 (1950).

Studien zum römische Pfandrecht, in TR 44 (1976).

Zur 'iusta causa traditionis', in BIDR 64 (1961).

KIENINGER, Eva-Maria, Mobiliarsicherheiten im Europäischen Binnenmarkt, Baden-Baden, Nomos, 1996.

KRELler, Hans, Formula fiduciae' und Pfandedikt, in SZ 62 (1942). Pfandrechtliche Interdikte und Formula Serviana, in SZ 64 (1944).

KrüCKManN, Paul, Einige Randfragen zum "periculum emptoris", in SZ 59 (1939).

KRÜGER, Hugo, Die "humanitas" und die "pietas" nach den Quellen des römischen Rechts, in SZ 19 (1898).

KUNKEL, Wolfgang, Hypothesen zur Geschichte des römischen Pfandrechts, in $S Z 90$ (1973). 
LA PIRA, Giorgio, La struttura classica della "conventio pignoris", in Studi in memoria di Umberto Ratti, Milano.

LAMBERTINI, Renzo, In tema di iusta causa traditionis, in Fides Humanitas Ius Studi in onore di Luigi Labruna, v. 4, Napoli, Editoriale Scientifica, 2007.

LAMBrinI, Paola, Lineamenti storico-dogmatici della fiducia cum creditore, in La garanzia nella prospettiva storico-comparistica, $1^{\text {a }}$ ed., Salisburg, Iustitiam Colimus, 2001.

LAROMBIÈRE, Léobon Valéry Léon Jupille, Théorie et pratique des obligations, t. 4, Paris, A. Durant et Pedore-Lauriel, 1885.

LEICHT, Pier Silverio, Laesio enormis e iustum pretium, in Studi di Storia e Diritto in onore di Carlo Calisse, Milano, Giuffrè, 1940.

LENEL, Otto, Das Edictum perpetuum (ein Versuch zu dessen Wiederherstellung), Leipzig, Tauchnitz, 1883.

, Palingenesia iuris civilis (iuris consultorum reliquae quae Iustiniani Digestis continentur ceteraque iurisprudentiae civilis fragmenta minora secundum auctores et libros disposuit) I e II (1889), reimpr., Aalen, Scientia, 2000.

Quellenforschungen in den Edictcommentaren, in SZ 3 (1882).

LeONHARD, Nicolas, Commissoria lex, in Pauly-Wissowa R.E., 4, 1 (1900).

LEVY, Ernst, Zu den Rücktrittsvorbehalten des römischen Kaufs, in Gesammelte Schriften II, Köln, Böhlau, 1963.

LIARD, Ambroise, Les principaux apports de la réforme des sûretés, in Option Finance. 880 (2007).

LiQuidato, Alexandre Gaetano Nicola, $O$ contrato de penhor (tese de doutorado em Direito Civil), São Paulo, FADUSP, 2012.

LoJacono, V. , Il patto commissorio nei contratti di garanzia, Milano, Giuffrè, 1952.

LONGo, Carlo, Corso di diritto romano - La fiducia, $1^{\mathrm{a}}$ ed., Milano, CEDAM, 1946. Datio in solutum - Diritto romano in NNDI 5 (1957). 
, Fiducia cum creditore, in Per Il XIV centenário della codificazione giustinianea, Pavia, 1934.

, Sulla "in diem addictio" e sulla " lex commissoria” nella vendita, in BIDR 31 (1921).

Vocabolario delle Costituzioni latine di Giustiniano, in BIDR 10 (1897-1898).

LuMinoso, Angelo, Alla ricerca degli arcani confini del patto commissorio, in Rivista di Diritto Civile, v. 36, Padova, 1990.

, La vendita con riscatto - art. 1500-1509, in Il codice civile, $\mathrm{P}$. SCHLESINGER (org.), Milano, Giuffrè, 1968.

MADEIRA, ELIANE, "Laesio Enormis" (tese de doutorado), São Paulo, FADUSP, 1998.

MAFFEI, Domenico, Condizione nel negozio giuridico (diritto intermedio), in ED 8 (1961).

MAHAFFY, John Pentland, The silver age of the Greek world, Chicago-London, Elibron Classics, 1906.

MANCINI, T., Vendita con patto di riscatto e nullità ex art. 2.744 codice civile, in Foro Italiano, Torino, Giappichelli, 1966.

MANIGK, Alfred, Fiducia, in RE 6 (1909).

, Gräko-ägyptisches Pfandrecht, in SZ 30 (1909).

_, “Hypotheca”, in RE 17 (1914).

, "Pignus", in RE 39 (1941).

, Pfandrechtliche Untersuchungen, v. 1, Breslau, M\&H. Marcus, 1904.

Manresa y Navarro, José Maria, Comentarios al Código civil español, t. 12, Madrid, Reus, 1969.

MARCADÉ, Victor, Explication théorique et pratique du Code Napoléon, t. 2, Paris, Delamonte, 1867.

MarcheSe, Rosa Rita, Picone, Giusto, Marco Tullio Cicerone - De officiis Quel che è giusto fare, Torino, Einaudi, 2012.

MARCONDES, Sylvio, Da fraude contra credores - falência e alienação de estabelecimento, in Questões de direito mercantil, São Paulo, Saraiva, 1977. 
, Restituição na lei falimentar e a figura especial do art. $76, \$ 2^{\circ}$, in Problemas de direito mercantil, São Paulo, Max Limonad, 1970.

MARICONDA, Vincenzo, Trasferimenti commissori e principio di causalità, in Foro Italiano, Torino, Giappichelli, 1989.

MARrone, Matteo, Istituzioni di diritto romano, Palermo, Palumbo, 1989.

Martinez, Pedro Romano, DA Ponte, Pedro Fuzeta, Garantias de cumprimento, $4^{\mathrm{a}}$ ed., Coimbra, Almedina, 2003.

MaschI, Carlo Alberto, "Humanitas" come motivo giuridico - con un esempio nel diritto dotale romano, in Annali Triestini, v. 18, Trieste, Università di Trieste, 1948.

, "Humanitas" romana e "caritas" cristiana come motivi giuridici, in JUS - Rivista di scienze giuridiche I, Milano, Università Cattolica del Sacro Cuore, 1950.

MASI, Antonio, Deficienza e adempimento fittizio della condizione mista in diritto classico e in diritto giustinianeo, in Studi economico-giuridici pubblicati per cura della Facoltà di Giurisprudenza della Università di Cagliari, Padova, CEDAM, 1964.

Studi sulla condizione nel diritto romano, Milano, Giuffrè, 2000.

MastropaOlo, Fulvio, I contratti autonomi di garanzia, $2^{\mathrm{a}}$ ed., Torino, UTET, 1995.

Mazzarino, Antonio, Introduzione al "De agi cultura" di Catone, Roma, Atlante, 1952.

MCCORMACK, Gerard, Secured Credit under English and American Law, Cambridge, Cambridge University Press, 2004.

MeIRA, Sílvio Augusto de Bastos, O pensamento criador de Teixeira de Freitas, in Novos e velhos temas de direito, Rio de Janeiro, Forense, 1973.

, Teixeira de Freitas (o jurisconsulto do império), Rio de Janeiro, Olympio, 1979.

Melillo, Generoso, Contrahere, pacisci, transigere - contributi allo studio del negozio bilaterale romano, Napoli, Liguori. Patti (storia), in ED 32 (1982). 
MENDES, Armindo Ribeiro, O processo executivo e a economia, in Sub judice Justiça e Sociedade, n. ${ }^{\circ}$ 2, 1992.

Menezes Campos, Maria Izabel Helbling, Da Hipoteca - Caracterização, Constituição e Efeitos, Coimbra, Almedina, 2003.

Menezes Cordeiro, Antônio, Da Boa fé no direito civil, Coimbra, Almedina, 2001.

Direito das Obrigações, $3^{\circ}$ vol., Contratos em Especial - Compra e Venda, Sociedade, Mútuo, Mandato, Empreitada, 2a ed., Lisboa, Faculdade de Direito de Lisboa, 1991. Antônio, Direitos Reais, Lisboa, Lex, 1993;

Messina Vitrano, Filippo, Per la storia dell'ius distrahendi, Palermo, Luigi Gaipa, 1910.

Messineo, Francesco, Manuale di diritto civile e commerciale, v. 3, 9a ed., Milano, Giuffré, 1959.

MICCIO, Renato, Cessione dei beni ai creditori, in ED 6 (1960).

MiCHeL, Jacques-Henri, L'influence de la “lex venditionis” sur les regles su contrat de vente, in RIDA 13 (1966).

Minniti, Giuseppe, Patto marciano e irragionevolezza del disporre in funzione di garanzia, in Rivista di diritto commune I, 1997.

Mirabelli, Giuseppe, Diritto dei Terzi secondo il codice civile italiano, I, Torino, 1889.

MITTEIS, Ludwig, Reichsrecht und Volksrecht in den östlichen Provinzen des römischen Kaiserreichs, German, Nabu, 1891.

Molitor, Erich, Schuldrecht I - Allgemeiner Teil, $8^{\mathrm{a}}$ ed., München, C. H. Beck, 1965.

MonaCI, Alfredo, La visione e il labaro di Costantino, Roma, L. Ricca, 1913.

MonNier, Raymond, Manuel elémentaire de droit romain, v. 2, $5^{\mathrm{a}}$ ed., Paris, Domat Montchrestien 1947.

MoNTEL, Alberto, Garanzia, in NNDI 7 (1965).

Morace Pinelli, Arnaldo, Trasferimenti a scopo di garanzia da parte del terzo e divieto del patto commissorio, in Giurisprudenza Italiana, Torino, UTET, 1994. 
Moreira Alves, José Carlos, As normas de proteção ao devedor e o "favor debitoris" - Do Direito Romano ao Direito Latino-Americano, In Notícia do Direito Brasileiro III, Brasília, UNB, 1997.

O "favor debitoris" como princípio geral de direito, in Revista

Brasileira de Direito Comparado, n. 26, Rio de Janeiro: Instituto de Direito Comparado Luso-Brasileiro, 2004.

, Da alienação fiduciária em garantia, $3^{\mathrm{a}}$ ed., Forense, Rio de Janeiro, 1987.

Direito Romano, $17^{\mathrm{a}}$ ed., Rio de Janeiro, Forense, 2009.

Mota Pinto, Carlos Alberto da, Teoria geral do direito civil, $3^{\mathrm{a}}$ ed., Coimbra, Coimbra, 1991.

NARDI, Sandro, Appunti in tema di patto commissorio e violazione del principio di solidarietà, in Giustizia Civile - Repertorio generale annuale di legislazione, bibliografia, giurisprudenza, Milano, Giuffrè, 2005.

Neves, Celso, Comentários ao código de processo civil, v. 7 (arts. 646-795). $7^{\text {a }}$ ed., Rio de Janeiro, Forense, 1999.

Estrutura fundamental do processo civil - Tutela jurídica processual, ação, processo e procedimento, Rio de Janeiro, Forense, 1997.

Nicolò, Rosario, L'adempimento indiretto del debito altrui, Milano, Giuffrè 1936.

, Responsabilità patrimoniale, in Della responsabilità patrimoniale, delle cause di prelazione e della conservazione delle garanzie reali, NicOLO, R., ANDRIOLI, V., GORLA, G. (org.), $2^{\text {a }}$ ed., Bologna-Roma, 1958.

nOORdraven, Bert, Pomp., D. 13, 7, 6 pr. - Un caso di “pignus”, in BIDR 56 (1980).

NöRR, Dieter, "Fides” im römischen Völkerrecht, 1931, trad. esp. de R. Domingo, La fides em el derecho internacional romano, $1^{\mathrm{a}}$ ed., Madrid, Fundacion Seminario de Derecho Romano Urscino Alvares, 1996.

OBERTo, Giacomo, Vendita con patto di riscatto, divieto del patto commissorio e contratto di lease back, in Quadrimestre, Milano, Giuffrè, 1984. 
Oertmann, Paul, Die Fiducia im römischen Privatrecht, Berlin, Guttentag, 1890

ORESTANO, Riccardo, Condizione (diritto romano), in NNDI 3 (1959).

Orlandis RoviRa, José, La prenda como procedimiento coactivo, in Actas del Congreso Iberoamericano de Derecho Romano, t. 14, Madrid, Universidad de Murcia, 1942-1943.

Pacifici-Mazzoni, Emidio, Istituzioni di diritto civile italiano, v. 4, $5^{\mathrm{a}}$ ed., Torino, UTET, 1927.

Palma, Antonio, Humanior interpretatio - 'Humanitas" nell'interpretazione e nella normazione da Adriano ai Severi, Torino, G. Giappichelli.

Pandolfi, Gaetano, Scarpello, Gaetano, Ritcher, Mario Stella, Dallari, Gastone, Codice civile - libro della tutela dei diritti illustrato com i lavori preparatori e com note di commento, Milano, Giuffrè, 1941.

PaOl, Ugo Enrico, Ipoteca (diritto attico), in Nuovo Digesto Italiano, v. 17, Torino, Torinese, 1938.

PenNitz, Martin, Das "periculum” rei venditae” (ein Beitrag zum “Aktionenrechtlichen Denken” im römischem Privatrecht), Wien, Böhlau, 2000.

Penteado, Luciano de Camargo, Direito das coisas, São Paulo, RT, 2008.

Penteado, Mauro Bardawil, O penhor de ações no direito brasileiro, São Paulo, Malheiros, 2008.

Pereira, Lafayette Rodrigues, Direito das coisas, v. 2, Brasília, Senado Federal, 2004.

Perlingieri, Pietro, Manuale di diritto civile, Napoli, Jovene, 2007.

Pernice, Alfred, Labeo - Römisches Privatrecht im ersten Jharhundert der Kaiserzeit, $2^{\mathrm{a}}$ ed., Halle, 1895.

PerozzI, Silvio, Istituzioni di Diritto Romano I, Firenze, G. BarberÀ, 1906.

PeTERS, Frank, Die Rücktrittsvorbehalte des römischen Kaufrechts, Köln, Böhlau, 1973.

Piedelievre, Stéphane, Premier aperçu sur la réforme du droit des sûretes par l'ordonnance du 23 mars 2006, in Répertoire du Notariat Defrénois 10 (2006).

PIERINI, Cesare, La legge commissoria, Pisa, T. Nistri \& Co., 1886. 
Pinto Duarte, Rui, Curso de Direitos Reais, Principia, Cascais, 2002.

Pinto, Rui, Penhora, Venda e Pagamento - Algumas Notas em Face das Alterações Impostas pelo Decreto-Lei n. ${ }^{o}$ 38/2003, de 8 de Março, Lisboa, Lex, 2003.

Pires de Lima, Fernando Andrade, Antunes Varela, João de Matos, Código Civil Anotado, v. 1, 4ª ed., Coimbra, Coimbra, 1987.

PitTerI, Francesco, M. Tullii Ciceronis Opera Quae Supersunt Omnia, v. 10, Venetiis, Studio Bibliografico Benacense, 1731.

Pontes de Miranda, Francisco Cavalcanti, Comentários ao código de processo civil, t. 11 (arts. 736-795), Rio de Janeiro, Forense, 1976. , Comentários à Constituição de 1967, t. 5, São Paulo, RT, 1968. Tratado de direito privado, t. 20, $3^{\mathrm{a}}$ ed., são Paulo, RT, 1983.

Poveda Velasco, Ignacio Maria, A execução do devedor no Direito Romano “Beneficium competentiae”, São Paulo, Paulista, 2002.

Ignacio Maria, Três vultos da cultura jurídica brasileira - Augusto

Teixeira de Freitas, Tobias Barreto de Menezes e Clóvis Beviláqua, in História do direito brasileiro (leituras da ordem jurídica nacional), São Paulo, Atlas, 2003.

PugliatTi, Salvatore, Esecuzione forzata e diritto sostanziale, Milano, Giuffrè, 1935.

Precisazioni in tema di vendita a scopo di garanzia, in Diritto civile, Metodo-teoria-pratica, Saggi, Milano, Giuffrè, 1951.

Pugliese, Giovanni, Intorno alla validità della vendita con scopo di garanzia, in Rivista di diritto civile, Padova, CEDAM, 1955.

SitzIA, Francesco, VACCA, Letizia, Istituzioni di diritto romano, $2^{\mathrm{a}}$ ed., Torino, Giappichelli, 1990.

, La simulazione nei negozi giuridici, Padova, CEDAM, 1938.

QueIRoz DE MoRAeS, Bernardo Bissoto, O pacto de melhor comprador Configuração no direito romano ("in diem addictio") e projeções no direito atual, Madrid, Dykinson, 2010.

RAAPE, Leo, Der Verfall des griechischen Pfandes besonders des griechischägyptischen, Halle, David Brown Book Company, 1912. 
, Verfallklausel bei Pfand und Sicherung-Übereignung, Berlin, F. Vahlen, 1913.

RABEL, Ernst, Die Verfügungsbeschränkungen des Verpfänders besonders in den Papyri, Lipsia, University of California Libraries, 1909.

, Grundzüge des römischen Privatrechts, in Holtzendorff-Kohler Enzyklopädie der Rechtswissenschaft, Leipzig und Berlin, Auflage.

, Grundzüge des römischen Rechts, Basel, Benno Schwabe \& Company Verlag, 1955.

REALMONTE, Francesco, Le garanzie immobiliari, in Jus, Milano, Università Catolica del Sacro Cuore, 1986.

Stipulazioni commissorie, vendita con patto di riscatto e distribuzione dei rischi, in Foro Italiano, Torino, Giappichelli, 1989.

Reglero Campos, Luis Fernando, Ejecución de las garantías en la contratación mercantil, v. 2, Madrid, Consejo General de los Colegios Oficiales de Corredores de Comercio-Civitas, 1996.

REIS, José Alberto dos, Processo de Execução, v. 2, Coimbra, Coimbra, 1982.

ReMÉDIo MARQUeS, Jõao Paulo Fernandes, Locação financeira restitutiva (sale and lease-back) e a proibição dos pactos comissórios - Negócio fiduciário, mútuo e acção executiva, in Boletim da Faculdade de Direito da Universidade de Coimbra, v. 77, Coimbra, 2001.

ReStiffe Neto, Paulo, Restiffe, Paulo Sérgio, Garantia fiduciária, $3^{\text {a }}$ ed., São Paulo, RT, 2000.

Riccobono Jr., Salvatore, "Humanitas", in Il Circcolo Giuridico (1950), Palermo, Michele Montaina, 1950.

L'idea di "humanitas" come fonte di progresso del dirito, in Studi in onore di Biondo Biondi, v. 2, Milano, Giuffrè, 1963.

Studi critici sulle fonti del diritto romano, in BIDR 8 (1895).

RivA, Ilaria, Il contratto di "sale and lease back" e il divieto del patto commissorio, in Contratto e Impresa, v. 17, n. 1, Padova, 2001.

RocCI, Lorenzo, Vocabolario Greco-Italiano, 39ª ed., Roma, Dante Alighieri, 2005. 
RoDotà, Stefano, Dazione in pagamento - diritto civile, in ED 11 (1962).

Rodrigues Bastos, Jacinto Fernandes, Das Obrigações em Geral - Segundo o Código Civil de 1966, v. 4, Viseu, Guerra, 1973.

RodrigueS, Silvio, Direito civil - Direito das coisas, v. 5, 20ª ed., São Paulo, Saraiva, 1993.

RoPPo, Enzo, La responsabilità patrimoniale del debitore, in Trattato di Diritto Privato, P. RESCIGNO (org.), v. 19, Torino, UTET, 1985. Note sopra il divieto del patto commissorio, in Rischio Contratuale e Autonomia Privata, Napoli, Jovene, 1982.

RoTONDI, Giovanni, Vecchie e nuove tendenze per la repressione dell'usura, in Rivista di Diritto Civile, Padova, CEDAM, 1911.

Rotond, Mario, L'azione di arricchimento, Milano, F. Vallardi, 1924.

Rubino, Domenico, La responsabilità patrimoniale - Il pegno, $2^{\mathrm{a}}$ ed., Torino, UTET, 1949.

SACCHI, Alessandro, Sul patto commissorio in diritto romano, in Archivio Giuridico 55 (1865).

Santangelo, Sabatino, Fiducia cum creditore: mandato irrevocabile a sopo di garanzia, in Fiducia, Trust, Mandato ed Agency, Milano, Giuffrè, 1972.

SANTARELLI, Umberto, Il divieto delle usure da canone morale a regola giuridica - Modalità ed esiti di un trapianto, in Riv. Storica del diritto italiano, v. 56, 1993. Santoro, Riccardo, Su D. 46, 3, 80 (Pomp. 4 ad Quintum Mucium), in Annali del Seminario Giuridico dell 'Università degli Studi di Palermo (AUPA), v. 55, Torino, Giappichelli, 2012.

Santos, Eduardo dos, Curso de Direitos Reais - Direitos Reais de Garantia e de Aquisição, Lisboa, Universidade Livre de Lisboa, 1986.

Sargenti, Manlio, Il 'de agri cultura' di Catone e le origini dell'ipoteca romana, in SHDI 22 (1956).

SASSI, Andrea, Garanzia del credito e tipologie commissorie, Napoli, Edizioni Scientifiche Italiane, 1999.

SCHEURL, Adolf, Zur Lehre von den Nebenbestimmungen bei Rechtsgeschäften, Erlangen, 1871. 
SCHIPANI, Sandro, Il "méthodo didáctico" di Augusto Teixeira de Freitas (prime osservazioni), in La codificazione del diritto romano comune, Torino, Giappichelli, 1999.

SCHUlz, Fritz, Das Ediktssystem in den Paulus-Sentenzen, in SZ 47 (1927). History of roman legal science, London, Oxford University, 1946. ,Prinzipien des römischen Rechts, München und Leipzig, Duncker \& Humblot, 1934.

SCIALOJA, Vittorio, Negozi giuridici (1933), $5^{\mathrm{a}}$ reimpr., Roma, Foro Italiano, 1950. , Teoria della proprietà nel diritto romano II, Roma, Sampaolesi, 1931.

SEGRÈ, Emilio Gino, Corso di diritto romano - Le obligazione personali e reali, Torino, Coop. Libri Del G.U.F., 1934.

SENN, Félix, L'in diem addictio, in NRH 37 (1913). , La dation des arrhes, in NRH 37 (1913).

SERICK, Rolf, Deutsche Mobiliarsicherheiten, Heidelberg, Recht und Wirtschaft, 1988.

Eigentumsvorbehalt und Sicherungsübertragung VI, Heidelberg, Recht und Wirtschaft, 1963.

Freigabeklausen, Deckungsgrenze und Haftungsbegrenze, in Neue juristische Wochenschrift, München, Beck, 1997.

SERRAO, Feliciano, Legge (dir. rom.), in ED 23 (1973).

SIBER, Heinrich, Römisches Recht in Grundzügen für die Vorlesung II Römisches Privatrecht, Berlin, 1928.

Silva Pereira, Caio Mário da, Instituições de direito civil, v. 4, 19a ed., Rio de Janeiro, Forense, 2012.

Silva, Ovídio Batista da, Ação de imissão de posse, $2^{a}$ ed., São Paulo, RT, 1997.

SILVEIRA MARCHI, Eduardo César, Concurso de Credores - e "pactum ut minus solvatur", Lecce, Edizione del Griffo, 1997.

Dos riscos pela perda fortuita da coisa vendida no direito romano, in Revista da Faculdade de Direito (Universidade de São Paulo) 96 (2001). 
"Periculum rei venditae" e "periculum dotis aestimatae”, in Labeo 47 (2001).

Stolfi, Giuseppe, Promessa di vendita e patto commissorio, in Foro padano Rivista di Giurisprudenza e dottrina, Torino, Giappichelli, 1957.

Talamanca, Mario, Contributi allo studio delle vendite all'asta nel mondo classico, in Atti della accademia nazionale dei Lincei, Roma, Accademia Nazionale dei Lincei, 1955.

, Istituzioni di diritto romano, Milano, Giuffrè, 1990.

, La "bona fides" nei giuristi romano - "Leerformel" e valori dell'ordenamento, in L. GAROFALO (org.), Il ruolo della buona fede oggetiva nell'esperienza giuridica storica e contemporanea, v. 2, Padova, CEDAM, 2003.

, La tipicità dei contratti romani fra "conventio" e "stipulatio" fino a

Labeone, in Contractus e pactum (tipicità e libertà negoziale nell'esperienza tardo-republicana), Napoli, Edizioni Scientifiche Italiane, 1990.

, Vendita in generale (diritto romano), in ED 46 (1993).

, Recensão a F. Peters, Die Rückstrittsvorbehalte des römischen Kaufrechts, in IURA, n. 24 (1973).

TeiXeira de Freitas, Augusto, Consolidação das leis civis, v. 1, Brasília, Senado Federal, 2003.

, Esboço do Código Civil, v. 1,3, Brasília, Fundação Universitária de Brasília, 1983.

THEOdORo JR., Humberto, A insolvência civil - Excecução por quantia certa contra devedor insolvente, $5^{\mathrm{a}}$ ed., Rio de Janeiro, Forense, 2003.

TibiletTI, Gianfranco, Lex, in Dizionario Epigrafico di Antichità Romane, v. 4, fasc. 22-25, Roma, Istituto italiano per la storia antica, s.d., pp. 702-707;

Sulle 'leges' romane, in Studi in onore di Pietro de Francisci, v. 4, Milano, Giuffrè, 1955.

Troplong, Raymond-Théodore, Du natissement, du gage et de l'antichrèse Commentaire du titre XVII, livre III, du Code Civil, t. 19, Paris, Charles Hingray, 1847. 
VAlverde, Trajano de Miranda, Comentários à lei de falências, v. 1, 4ª ed., Rio de Janeiro, Forense, 1999.

VANZELLA, Rafael Domingos Faiardo, 'Numerus clausus' dos direitos reais e autonomia nos contratos de disposição brasileiro (tese de doutorado em Direito Civil), São Paulo, FADUSP, 2009.

VARRONE, Claudio, Il trasferimento della proprietà a scopo di garanzia, Napoli, Jovene, 1968.

VAsSali, Francesco, La cessione dei beni ai creditori, in Trattato di Diritto Privato, n. 13, P. RESCigno (org.), Torino, UTET, 1985.

VASSALLI, Filippo Euprichio, “Dies vel condicio”, in BIDR 27 (1914).

VAz Serra, Adriano, Hipoteca, in Boletim do Ministério da Justiça, n. 62, Lisboa, 1957.

Penhor, in Boletim do Ministério da Justiça, n. ${ }^{\circ}$ 59, Lisboa, Gabinete de documentação e direito comparado, 1956.

Vélez SARSFIELd, Dalmacio, Codigo de la Republica Argetina - tales como fueron publicadas, Buenos Aires, Pablo e Coni, 1872.

Venosa, Silvio de Salvo, Direito civil - Direitos reais, v. 5, $11^{\text {a }}$ ed., São Paulo, Atlas, 2011.

Viale Salazar, Fausto, El derecho de prenda y la realización de la prenda en lós códigos civiles de la República de Chile y de la República Argentina que recogen los proyectos Bello y Vélez Sársfield, respectivamente, in Revista Pontificia Universidad Católica del Perú, $\mathrm{n}^{\circ}$ 42, Lima, Pontificia Universidad Católica del Perú, 1987.

Vigié, Albert, Cours élémentaire de droit civil français, t. 2, $3^{\mathrm{a}}$ ed., Paris, Librairie Nouvelle de Droit et de Jurisprudence, 1905.

VILLA, Gianroberto, Contratto e violazione di norme imperative, Milano, Giuffrè, 1993.

Villaça Azevedo, Álvaro, Dação em pagamento in ESD 22 (1977).

VISKY, Károly Appunti sulla origine della lesione enorme, in IURA 12, 1961. 
Vitelli, Girolamo, Atene e Roma - Bullettino della Società Italiana per la Diffusione e l'Incoraggiamento degli Studi Classici, n. 27 e 59, Firenze, Società Italiana per la Diffusione e l'Incoraggiamento degli Studi Classici, 1901 e 1903.

Vivante, Cesare, Del contratto di assicurazione - di pegno - di deposito nel magazzini generali, in Il codice di comercio commentato, L. BOLAFFIO - A. RocCO-C. VIVANTE (org.), 6 a ed., v. 7, Torino, UTET.

, Tratatto di diritto commerciale, v. 4, $5^{\mathrm{a}}$ ed., Milano, Fratelli, Bocca, 1926, p. 282.

VOLKMAR, Erik, Commissorius, in VIR, v. 1, Berlin, Georg Reiner, 1903.

VolterRA, Edoardo, Istituzioni di diritto romano (1961), reimpr., Roma, La Sapienza, 1993.

VON BESELER, Gerhard, Romanistische Studien, in TR 8 (1928).

VoN LüBTOW, Ulrich, Studien zum altrömischen Kaufrecht II, in Festschrift Paul Koschaker, Weimar, 1939.

Wallon, Henri Alexandre, Histoire de l'esclavage dans l'antiquité, v. 3, $2^{\mathrm{a}}$ ed., Paris, Hachette, 1879.

WARREN, Elizabeth, Bankruptcy and Article 9 - Statutory supplement, Austin, Wolters Kluwer, 2010.

WARREN, Elizabeth, WeSTBROOK, Jay Lawrence, The law of debtors and creditor - Text, cases and problems, $6^{\mathrm{a}}$ ed., Austin, Wolters Kluwer, 2009.

WATson, Alan, Roman Law \& Comparative Law, $1^{\mathrm{a}}$ ed., Athens and London, The University of Georgia, 1991. , The Origins of Fiducia, in SZ 79 (1972).

WeSSEly, Carl Franz Joseph, Die Stadt Arsinoe (Krokodilopolis) in griechischer Zeit, in Sitzungsberichte der philosophisch-historischen Classe der kaiserlichen Akademie der Wissenschaften zu Wien, Wien, Carl Gerold \& Sohn, 1901.

WIEACKER, Franz, Lex commissoria - Erfüllungszwang und Widerruf im römischen Kaufrecht, Berlin, Springer, 1932.

WINDSCHEID, Bernhard, Lehrbuch des Pandeltenrechts I e II, 1900, trad. it. de C. Fadda e P. E. Bensa, Diritto delle Pandette I (1902) e II (1904), reimpr., Torino, UTET, 1925. 
Yoshikawa, Eduardo Henrique de Oliveira, Execução extrajudicial e devido processo legal, São Paulo, Atlas, 2010.

ZACCARIA, Alessio, La prestazione in luogo di adempimento - Fra novazione e negozio modificativo dei rapporto, Milano, Giuffrè, 1987.

ZACCHEO, Massimo, Gestione fiduciaria e disposizione del diritto, Milano, Giuffrè, 1991.

ZIMMERMAN, Reinhard, The law of obligations - roman foundations of the civilian tradition, London, Oxford University, 1996.

ZINGaLe, Livia Migliardi, In tema di 'fiducia cum creditore' - I documenti della prassi, in Labeo 46 (2000).

ZINNECKER, Timothy, The Default Provisions of Revised Article 9, Chicago, American Bar Association, 2002. 